Portland State University

PDXScholar

7-18-1975

\title{
Moving toward integration: a study of theory and practice in feminist therapy
}

Susan Amelia Thomas

Portland State University

Follow this and additional works at: https://pdxscholar.library.pdx.edu/open_access_etds

Part of the Counseling Commons, Social Psychology Commons, and the Women's Health Commons Let us know how access to this document benefits you.

\section{Recommended Citation}

Thomas, Susan Amelia, "Moving toward integration: a study of theory and practice in feminist therapy" (1975). Dissertations and Theses. Paper 2516.

https://doi.org/10.15760/etd.2513

This Thesis is brought to you for free and open access. It has been accepted for inclusion in Dissertations and Theses by an authorized administrator of PDXScholar. Please contact us if we can make this document more accessible: pdxscholar@pdx.edu. 
AN ABSTRACT OF THE THESIS OF SUsan Amelia Thomas for the Master of Social Work presented July 18, 1975.

Title: Moving Toward Integration: A Study of Theory and Practice in Feminist Therapy

APPROVED BY MEMBERS OF THE THESIS COMMITTEE:

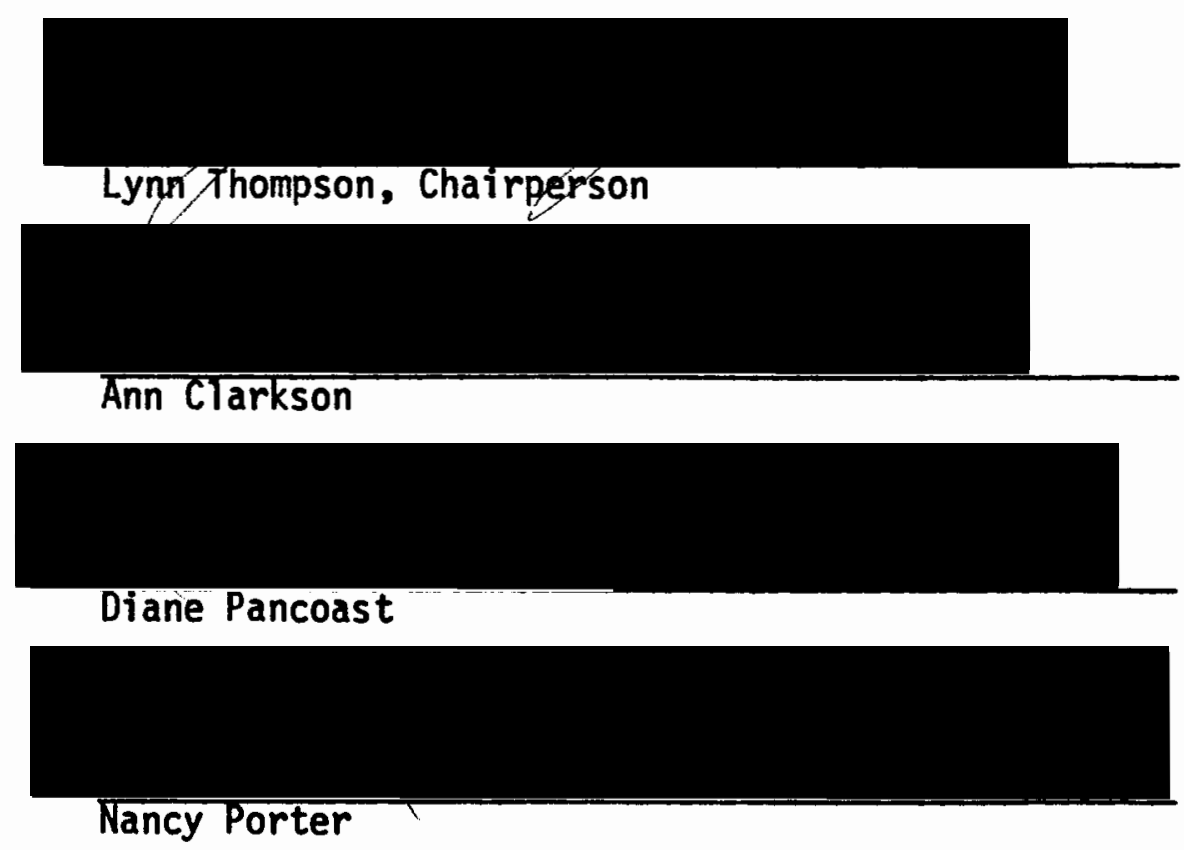

This thesis describes a study designed to explore the emerging field of feminist therapy. The goal was not to test the validity of feminist therapy, to probe the assumptions on which it is based, or to compare it to other forms of therapy but to characterize the theory and practice of feminist therapy as it now exists. Feminist therapy was seen as growing out of the cultural and historical context of the feminist movement, which includes a critique of society with emphasis on the particular psychological consequences for women, and a critique of 
psychotherapy, particularly Freudian psychotherapy, as oppressive to women and adhering to a double standard of mental health. The field of mental health responded to these criticisms, and feminism simultaneously began a search for alternatives to therapy. Out of both developed feminist therapy. The literature, both in the field and in the alternative press, was reviewed to present a picture of the development of feminist therapy and to highlight issues to pursue in the research itself. Following this review, a study was undertaken of feminist therapists in three metropolitan areas on the West Coast--Portland, Seattle, and the Bay Area--utilizing a qualitative methodology to gather descriptive data and potential patterns for analysis. A natural network approach was utilized to generate the population, following much the same process a woman would go through in locating a feminist therapist. Potential feminist therapists were surveyed via a questionnaire. Selfidentification as a feminist therapist was the primary criteria for inclusion in the sample frame. A random sample of 20 percent of the sample frame (20 feminist therapists) was interviewed, and the results transcribed and thematically analyzed to answer five questions:

1) Who are the feminist therapists?

2) How do feminist therapists define feminism?

3) What is feminist therapy?

4) How does feminist therapy perceive and incorporate therapeutic issues?

5) How does feminist therapy perceive and incorporate feminist issues?

Analysis of the characterizing data obtained from the questionnaire found little difference among the three areas surveyed. Common themes of non-traditionality and non-institutionalization of theoretical orientations, modes and focuses of practice, practice settings, and 
areas of specialization, were noted. Analysis of the interview data found that feminist therapists describe their identification with and awareness of feminism as a profound influence on their lives. They define feminism primarily as a belief system, encompassing what is called in the study a Feminist Critique of society and a Feminist Humanism. As feminist therapists define and describe feminist therapy, it is less a theoretical orientation than a belief system and a series of ways that belief system is put into practice. Feminist therapy is based on the feminist value or belief system, utilized as a filter, on particular changes in the therapy relationship and in the role of the therapist which enable the therapy process to become congruent with the value system, and on two processes--raising consciousness and emphasizing the commonality of all women--which enable the value system to be not merely utilized by the therapist but transferred to the client.

In discussing therapeutic issues (i.e., self-disclosure, diagnosis, the role of values), the primary focus of feminist therapists is the needs of the client. Generally, therapeutic issues are more important to feminist therapists than feminist issues, and issues presented in the literature and issues for feminist therapists are not the same. Within the group of feminist therapists interviewed, there are differences of opinion and perspective on many issues, along a humanistic/radical continuum, particularly with regard to issues of directiveness. Feminist therapy is not inherently radical. The conclusion suggests that feminist therapy, as an example of cultural feminism, emphasizes integration and congruency, the minimization of onctradictions and the achievement of connections and internal consistency. 


\title{
MOVING TOWARD INTEGRATION: A STUDY OF THEORY AND PRACTICE. IN FEMINIST THERAPY
}

by

SUSAN AMELIA THOMAS

\begin{abstract}
A thesis submitted in partial fulfiliment of the requirements for the degree of

MASTER OF SOCIAL WORK
\end{abstract}

Portland state intiversity

1975 
TO THE OFFICE OF GRADUATE STUDIES AND RESEARCH:

The members of the Committee approve the thesis of

Susan Amelia Thomas presented July 18, 1975.

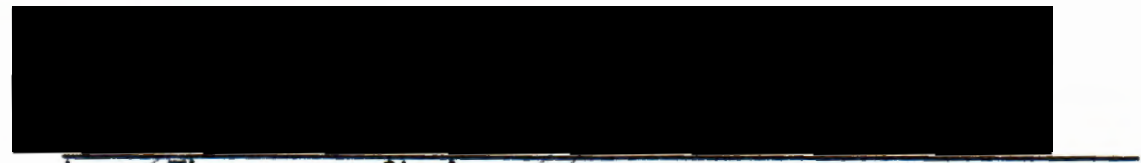

Lynn Thompson, Chairperson

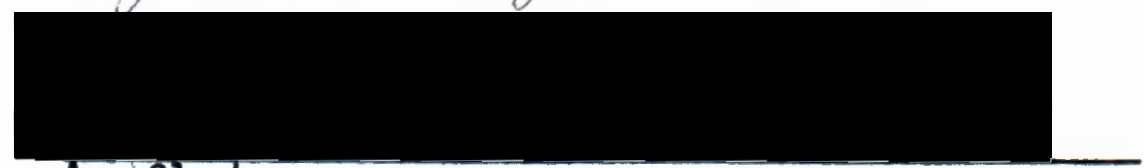

Ann Clarkson

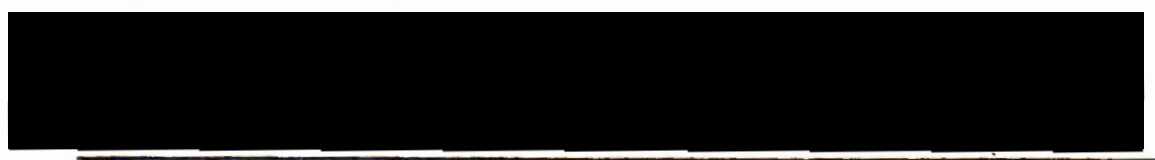

Diane Pancoast

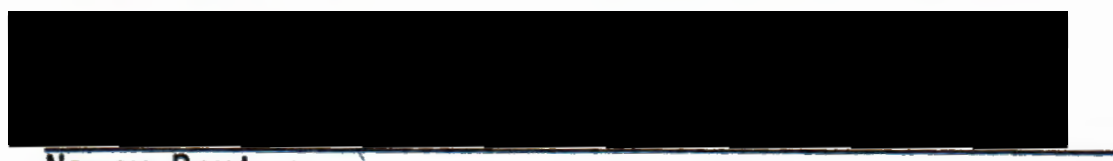

Nancy Porter

APPROVED:

Gordon Hearn, Dean, School of Social Work

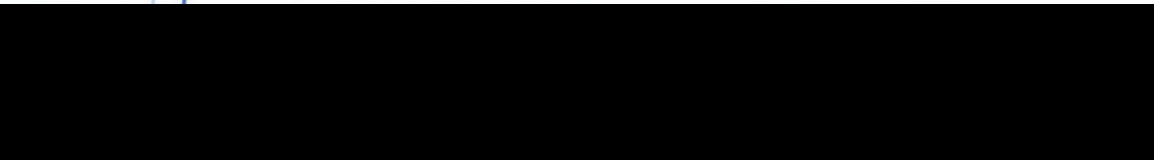

David T. Clark, Dean of Graduate Studies and Research

Ju1y 18, 1975 
Like so many of us now, I'm experimenting with life, trying to get it rignt, to do it better, aware how often we're merely rationalizing--but still trying to create a new kind of social existence.

-..Kate Millet, Fiying.

Where do correct ideas come from? Do they fall from the sky? No. Do they spring innateiy from our minds? No. They come from social practice and from it aione.

--Mao Tse-Tung

Our history has been stolen from us. our heroes died in childbirth

from peritoritis, from bottied up rage. our geniuses were never taught to write. We must invent a past arequate to cur ambitions.

We must invent a future adequate to our needs. - Women in Transition 
TABLE OF CONTENTS

PAGE

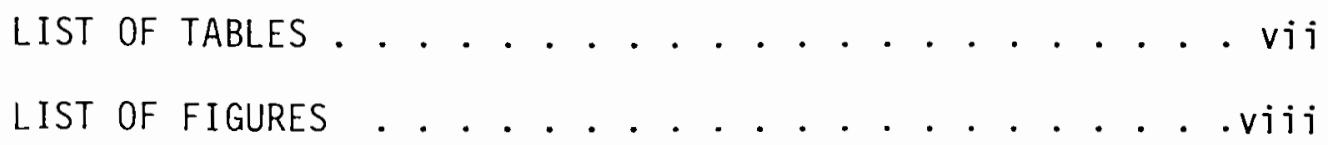

CHAPTER

I. InTRODUCTION . . . . . . . . . . . 1

II. REVIEW OF THE LITERATURE . . . . . . . . . . 4

Introduction ........... . . 4

The Rise of the Second Wave of Feminism. . . 6

The Feminist Critique. . . . . . . 10

Psychological Effects of Sex-Role Oppression.......... 14

Feminist Critique of Freud . . . . . . 21

Feminist Repudiation of Psychology and Psychotherapy ......... 21

Research Regarding the Double Standard of Mental Health......... . 32

Mental Health Field Responds to Feminism . . . . . . . . 35

Feminist Movement in Search of Alternatives......... 45

Feminist Therapy. . . . . . . . . 51

III. RESEARCH DESIGN . . . . . . . 65

Introduction . . . . . . . . 65 
Developing the Sample Frame and

Choosing the Sample... . . . . . 71

Instrument Development . . . . . . . . 84

Data Collection ............ 86

Data Analysis.............. . . 95

IV. FINDINGS . . . . . . . . . . . . 100

Who Are the Feminist Therapists?. . . . . 100

Questionnaire Analysis

Personal Histories of Feminism

Time Allocation

Portraits of Feminist Therapists

How Do Feminist Therapists Define

Feminism?.......... . . 121

Feminist Values

Definitions of Feminism

Feminist Criteria

other Comments on Feminism

What is Feminist Therapy? . . . . . . . . 140

Qualifications about Feminist Therapy

Descriptions of Feminist Therapy

Continuum of Feminist Therapy

Men as Feminist Therapists

Definitions of Feminist Therapy

How Does Feminist Therapy Perceive and

Incorporate Therapeutic Issues? . . . . 176

Values and Directiveness

Structure

Diagnosis

Working with Lesbian and Radical

Feminist clients

Power Issues

Answering Client Questions and Self-

Disclosure

Therapy as Political or Apolitical

Issue of Losing Potency by Incorporating

Feminism

Other Therapeutic Issues 
How Does Feminist Therapy Perceive and Incorporate Feminist Issues? . . . . . 234

Working with Male Clients

Professionalism and Training

Consciousness-Raising as an Alternative to Therapy

Issue of Therapy as an Individual Solution

Need for both Individual and Societal Focus

Working with Women in Groups versus Individualiy

Differentiating Cultural and Individual Problems

Limitations of Therapy

V. SUMMARY AND CONCLUSIONS . . . . . . . . . . 262

Summary of Research Findings . . . . . 262

Who Are the Feminist Therapists?

How do Feminist Therapists Define Feminism?

What is Feminist Therapy?

How does Feminist Therapy Perceive and Incorporate Therapeutic Issues?

How does Feminist Therapy Perceive and Incorporate Feminist Issues?

Conclusion . . . . . . . . . . . 274

BIBLIOGRAPHY . . . . . . . . . . . . 280

APPENDICES . . . . . . . . . . . . . . . 296

A. Cover Letter for Questionnaire . . . . . 296

B. Questionnaire ......... . . 297

C. Letter of Acknowledgment . . . . . . . 298

D. Schematic Representation of Interview Format. . . 299

E. Berkeley Feminist Therapy Referral Collective . . 301 


\section{LIST OF TABLES}

TABLE

PAGE

I. Generation of Potential Sample Frame . . . . . 75

II. Responses to, "Do You Consider Yourself to

be a Feminist Therapist or Counseior?" by

Percentages ........... . . 79

III. Questionnaire Responses by Percentëge . . . . . 81

IV. Non-Respondents in Groups by Percentaçe . . . . 82

V. Sampling of Non-Respondents ........ 83

VI. Theoretical Orientations of Feminist

Therapists . . . . . . . . . . 101

VII. Degree Levels of Feminist Therapists. . . . . .103

VIII. Focuses of Practice among Feminist Therapists. . 105

IX. Modes of Practice among Feminist Therapists. . . .105

X. Practice Settings of Feminist Therapists . . . . .107

XI. Categories of Definitions of Feminist Therapy. . .125

XII. Categories of Definitions of Feminist Therapy. . .175 


\section{LIST OF FIGLRES}

FIGURE

PAGE

I. Definitions of Feminism ......... 126

II. Criteria for Doing Feminist Therapy . . . . 129

III. Continuum of Responses to Presentation of Two Definitions of Feminist Therapy . . . . . . 165

IV. Continum of Responses to Question of Men as Feminist Therapists . . . . . . . 170

v. Definitions of Feminist Therapy....... 174 


\section{CHAPTER I}

\section{INTRODUCTION}

This study has grown out of my own needs for integration. I have felt my feminism to be an important part of my personal life and social understanding, and I have been searching for ways to incorporate it into other aspects of my life. One of those aspects has been my therapy, both as a client and as a therapist. I was profoundly influerced by Chesler's Women and Madness. Much like the experiences of many of the feninist therapists in this study in encountering feminism, reading that book was a turning point for me. There was finally support for my own perceptions of the ways that therapeutic mystification and institutionalization of the hierarchical power imbalance within the therapist/client roles, particularly if the therapist is a male and the client a feniale, contribute to--rather than alleviate--emotional distress. I began to try to figure out how I would want to do therapy differentiy. I knew what. it meant to me as a client to be told by a therapist, "You know, a lot of other women feel that way too." I knew what it moant to me as a client to have my perceptions of the therapist's greater power affirmed rather than denied, and the ways in which therapeutic contracis mitigated that power. I knew what it meant to me as a client to fee? a therapist as a real person sitting there, often with struggles very similar to my own. I decided that perhaps these thirigs--utiizing therapy to stress the social as well as the intra-psychic nature of wnne:'s emotional 
problems, "owning" the power imbalance and then builuing in structures (such as contracts) to mitigate its impact, and seif-disclosing-were ways I as a therapist could incorporate my feminism. into my therapy. However, I still kept feeling uncertain and unsettled. I felt conflicted and alone in trying to bring what seemed like a number of vague ideas into therapy. I was unsure how to integrate the training I was getting with my developing ideas about what feminist therapy would be. Were those conflicts between the model of therapy I was being taught and my ideas of feminist therapy as real as they seemed to me, and if they were, how was it that nobody seemed to understand what I was tâiking about when I discussed the therapist's power? Was answering client questions ard self-disclosing really making me less potent as a therapist? How much shouid I say about my feminist consciousness to my clients? Should I--did I have a right to--did I have a right not to--raise my client's consciousness? Were there some issues which, if dealt with therapeutically, were thereby implicitly discounting social realities? Somehow, I assumed that even if I didn't know the answers to these questions, sureiy other feminist therapists did.

Thus, the purpose of this research study becanie an exploraticn of the newly emerging field of feminist therapy. The goal was to characterize feminist therapy, drawing a profile of its theoretical perspectives, the nature of its practices and descriptions of feminist therapists. Because feminist therapy is at the begiming stages of development, conceptualization, and implementation with littie published or othermise available about its theoretical orientations or the nature of its practice, this study was not designed to test any hypothesis, to 
measure the validity of feminist therapy or any assumptions upon which it may be based, or to compare it to other non-feminist forms of therapy. Rather, the research utilizes a series of interviews with feminist therapists to gather descriptive data and potential patterns for an analysis of feminist therapy.

The following chapters contain an overview of the historical trends and theoretical ideas of the late 1960 s and first half of the 1970s out of which feminist therapy has developed, as well as a revieir of the information available on feminist therapy itself, a description of the research design utilized, a tabulation of responses from questionnaires sent to the available part of the population, a thematic analysis of interviews with a random sample of these feminist therapists, and finally, a discussion of the findings and conciusions of the study.

An important struggie for me has been to incorporate with in the study a multitude of individual variation in an inclusive rather than exclusive manner. This task was made easier because in each interview, I had the sense of each feminist therapist not in comparison to arother feninist therapist more radical or more humanistic, but as her own person with her own integration which I could deeply respect. It a? so soun became clear to me that none of us really know for sure yat what feminist therapy is, because it is as we develop it: and thus it is constantly changing. However, to the degree that the sample frame is representative of the population of feminist therapists in Portlarid, Seattle, and the Bay Area--which it was desigred to be--the results are generalizable statements about feminist therapy as it exists in these three areas on the West coast at this point in its develoument. 


\section{CHAPTER II}

\section{REVIEW OF THE LITERATURE}

\section{INTRODUCTION}

Because feminist therapy is so much in the process of development, the objectives of the review of the literature are two-fold. First, since much of the literature on feninist therapy or exp?aining its development is in the alternative rather than academic press, an attempt was made to enable the literature review to be utilized as an annotated bibliography, raising issues and suggesting further reading. Second. the literature review was dejigried to gather not only the relevant material written about feminist therapy per se but dso to provicie a background for understandiriz the instorical-cultural context out of which feminist therapy has emierged. Any new phenomenon-- such as feminist therapy--which suddeniy deveiops and spreads does so becaluse the historical and cultural context around it has already provided the necessary elements which it needs to be accepted and to grow-and in fact that context has produced it. Feminist therapy is seen as an icea "whose time had come." Thus, this riterature review will attempt to trace what are seen as those critical ideological and sociownistorical developments which began in the United States in the late 1950s and produced a group of therapists calling chemselves feminist therapists ment developed was originaly suggested to me by Lindsay (1974). 
doing something they call feminist therapy. Feminist therapy is of course only one of mary developnents of that cuitural mileau. This Titerature review, however, is concerned only with the particular development of feminist therapy, and those aspects of the feminist movement and the mental health field out of which it grew. As the Titerature review begins, its base is broad, including all cf feminism, but as it proceeds, it increasingly narrows in on those specific areas of feminism and mental health related to the development of feminist therapy.

Basically, feminist therapy has its roots in the rise of the second wave of feminism, out of which came an analys is of society, here entitled the Feminist Critique, a part of which dealt with psychological effects on women of sex-role oppression. One of the targets of feminist criticism was Freudian psychotherapy and then, increasingly, ali psychology and psychotherapy as male-dominated and adhering to a male standard of mental health. In the early i970s, the field of merital health began to respond to the criticisms and repudiations of the feminists, sometimes disparagingly, at other times supportively. Those who were supporive began to develop and publish new models for working with women $i r_{\text {s }}$ therapy at about the same time that feminism itself was developing alternatives to therapy in the consciousness-raising group, self-help counseling, and transition houses, as well as ways of nodifying therapy and women's experiences in therapy, utilizing referral services and calling for a new psychology for women. One of the things that developed from both. the responses of the mental health field and the feminist search for alternatives was feminist therapy.

Because so little ras actaliy been written in journals in the field on feminist themapy. a concentrated effort was made to utilize the 
feminist and aiternative media as well as the academic press. Where possible, all issues of the following newspapers and magazines vere surveyed:

Changing Wornan

Feminist Studies

Issues in Radical Therapy

KHOW2

Ms.

Notes fron the 1st, 2nd, and 3rd Years

off Our Backs

Pandora (a Seattle feminist paper)

Plexus (a San Francisco ferninist paper)

Radical Therapy

Second Wave

Up From Under

Women: A jouinal of Liberation

Women's Studies: An Interdisciplinary Journal

Aside from the section of the itterature review on the responses of mental health to feminism and the evidence of a doubie standard in mental health, the focus of the literature review is generally not psychological research in general but that research and theory seen as feninist or contributing to the feminist analysis or an understanding of that analysis.

\section{THE RISE OF THE SECOND WAVE OF FEMINISM}

In the mid-1970s in the United States there began a sociai movement called the "second waye" of feminism (Firestone 1970:15), so labeled because it was a re-awakening, albeit in somewhat different form, of the feminist movement of the late 1800s and early 1900s. The sociocultural and economic conditions of the fifties and eariy sixties made this a ripe time for such a movement to catch hold and develop (Dixon

2kNow is a feminist press in Pittsburgh (P.0. Box 86031). Mary of its publications are undated, and those utilized were included in following citations with kNo, in place of a date. 
1972; Doeneká 1972; Firestone 1970; Freeman 1971; Kontopâlulos 1972; Mitchell 1971), and in 1966 the National Organization for Women (now) was formed to focus on the legal and economic difficuities women face. In the years shortly thereafter, what Freeman (1971:3) calls the "younger branch" of the feminist movement formed, composed of women who oftan had had experiences in the Niew Left and civil rights movements. Unitke the "older branch," represented by Now, this "younger branch" eschewed structure and took pride in its lack of organization. "One resuit of this style is a very broad-based, creative movement, which individuais can reiate to pretty much as they desire with no concern for orthodoxy or doctrine."

in their search for support and direction, wonen formed "rap" groups, which scon became formalized into consciousness-raising groups. Although originaliy designed as a technique for mutual support and education, conscicusness-raising became more than that. It became a]ternately described as the heart and scul, the cornerstone or the foundation of the movement (Gornick 1972; Tennov KNOW; Nalker KNOW). In the consciousness-raising groups women struggled to "understand their lives and problens in terms of the pressures which inipirge on all women in the society" (Polk 1972:323). The purpose of the groups was to develop a socio-politicai anaiysis of the sociecy based on one's own experiences of being female. At the same time, by bringing womeri together in structured interactions to share cominon experiences, the consciousness-raising group chalrenged the individual isolation to which women have traditionaliy been subjected and provided feaings of identity, self-respect and collective corisciousness. Different. 
perspectives emphasized different aspects of consciousness-raising. Sone saw its primary functions as personal change. "Once one has gone through such a 'resocialization,' one's view of oneself and the worid is never the same again, whether or not there is further active participation in the meventent" (Freeman 1971:5). Some viewed personal i iberation as the strategy for the liberation of ail women; others saw it as merely the initial stage of awareness preceding entry into a mass political movernent (Tenrov kNOW). White and Goode (1961:55) saw the conscicusness-raising group itself as the microcosn of the new society. "The organization we build [internally in our groups] is the society our revolution will create." fillen (1970) stresses group adhesion, while Tennov (KNOW) feels that group dependency can impede personal autonony and the ultimate deveiopment of siscerhond. Nonetheless, all seem to agree on certain results of consciousness-raising groups, as articulated by Freeman (1971:5):

From this public sharing of experiences comes the realization that what was thought to be individual is in fact common; that what was thought to be a personal probiem has a social cause ond probabiy a political solution. Women learn to see hot socia! structures and attitudes have molded them from birth and limited their opportunities. They ascertain the extent to which women have been denigrated in this society and how they have developed prejudices aglainst themselves and bther women.

Studies were done comparing women invoived in the feminist movement with non-feminists (Kirsch 1974). In 1970, Steininann (1974) found feminists perceived themselves as extremeiy self-achicving, particuiarly rejecting those stereotypic role behaviors related to marriage and fämily and emphasizing self-realization and activities outside the hone.

Tavris (1972) analyzed 20,000 resporses to a questionnaire appearing in Psychology Today. She found women indicated as effects of participation 
in women's groups that they were more se?f-confident about combining marriage and career, most optimistic about working, more resentful of male prerogatives, angry at men more often, and liked women more. Dempewolff (1974b) found few differences in family background between supporters and opposers of feminism. However, differences were found on personality measurements. Supporters of feminisn demonstrated less need to maintain distance from those they considered an outgroup, suggesting security about self-worth. On a measure of independence of judgment, whereas opposers of feminism valued conformity and were highiy influenced by group consensus, supporters of feminism välued creative work, placed particular value on the person as an individual, were independent, tended to be intraceptive rather than extraceptive, and had the ability to resist group consensus. On a measure of autonomy, supporters of the women's movement tended to be more indepencent and individualistic as well as having a modern rather than traditionol outlook on life, with modernism defined as including feelings of control over one's destiny. Doeneka (1972) studied the effects of consciousnessraising groups on individuais, and found identity change, new selfconfrontation experiences, physical and/or behavioral modification, and changes in perceptions, attitudes, goals, and political strategies for goal attairment. She also found that exposure to some of the values and goals of feminism resulted in ar enctional identification with the movement. Cherniss (1972:117) commented upon the profound influence of participation in the movement, ciescribing it as a "striking experience.. . of great personal significance to the women involved." He concludes that the women's movement is more than anything else a style, 
a way of relating to the world which includes ari detive, outgoing approach, a high degree of achievement striving, and a strong valuation of autonomy and independence.

In 1969 and 1970, acceierated press pubricity and pubiication of such books as Sisterhood is Powerrui (Morgan 1970) and Sexuar Politics (Millet 1969) carried conscicusness-raising to the public as a whole. At the same time, divisions began to be apparent withix the feminist movement. NOW incorporated consciousness-raising as a regular activity (Bonetti 1974) and the divisions based on age (i.e., the older and younger branches) seemed less significant than differences in focus and political analysis, primarily around the issues of individual liberation vs. collective liberation and reform (or working within "the systeri" vs. counter-systemic activities or revolution). In the early 1970s, a)ternative institutions began to emerge and proliferate: women's bookstores, magazines, health clinics, restaurants, and switchboards sprang up across the country, and Women's Studies began to be recognized as a valid intellectual course of study.

\section{THE FEMINIST CRITIQUE}

Because of the varying origins, motivations and philosophical and political stances of the feminist movement, it is difficult to synthesize a set of beliefs or political perspectives that can be labeled "feminist." Freeman (1971) suggests that there is agreenent on two theoretical issues: 1) the feminist critique of society, and 2) the idea of oppression. In somewhat expanded form, that distinction will be used here. 
The feminist critique of society sees a traditional view stating women differ biologicaliy from men and therefore that they shouid serve different social functions and engage in different social roles. Feminism rejects these assumptions, believing that men and women are constitutionaily equal and therefore that differing roles and functions are the result of social conditioning and an institutionalized sexual class system-wit is socio-cultura? determinism as contrasted with biological determinisin. Following closeiy from the feminist critique of society is the idea that social conditioning and institutionalized sexual roles (particulariy as played out in marriage and the nuclear family), while oppressing both men and women, have oppressed women in particular by preventing them from functioning and contributing according to their potentials, relegating them to an inferior status, and enforcing their second-class citizenship. The basic argument is that women are the way they are because that's how they were trained to be, and how they were trained to be dehumanizes theliit, thwarts their potentials, and further maintains their already inferior. position. 3 Thus, the movement seeks ar, end to the myth that men are superior to women and an end to those practices and instititions of the society perpetuating that nith. While the classic works presenting this view are De Ecauvoir's The Second Sex (1952) and Freidan's The Feminine Mystique (1963), there is a plethora of literature expiaining--all from varying points of view-the feminist critique (i.e., Bem and Bem 1970; Greer 1970; Janeway 1971; Polk 1972; Westervelt 1973).

3Some writers, such as Bardwick (1975), stress more the role of female physiology and physiological differences but still acknowledge the role of social conditioning. 
Given this basic perspective, rowever, there are divisions within the feminist movement in emphasis and strategy look and stone 1973; Diggs 1972; Firestore 1970; Freeman 1971; Greer 1970; Polk 1972). Tiree main politicai tendencies are distinguishable, which digss iabeis ilberai feminism, cultural feminism, and socialist feminism. ${ }^{4}$ Liberal feminism (as articlilated by Friedan 1969, winong others) seaks the estabilishmeit of women's rights and the liberotion of women through iegal, eccromic, and political reform. It identifies the sources of women's oppression as sexist ideas, habits, prejudices and laws that are a part of the society, in particular Freudian psychology, functionalist social science, consumerism, and sexist educational theories and practices. The politice? objectives are full equality for women within this society based on an acceptance of the idea that the focus of change are ideas, prejudices: habits and laws but not basic political or economic institutions (Diggs 1972).

Cultural feminism (âs articulated by Firestone 1970, among others) defines the cause of wornen's oppression as two-fold: psychologically, as sex roles and any institution that supports a division according to sex roles; and politically as any hierarchical structure or institution. Cultural feminists enphasize the cormon oppression of all women and argue that female oppression is not merely the resuit of economic oppression and therefore would not disappear even after a revolutionary overthrow of capitalism. Cultural feminism utilizes a triple sirategy

${ }^{4}$ Firestone labeis then conservative feminists, radical feminists, and politicos; Dixon (1971-72) calis Diggs cultural feminists radical reactionary foninists. To go into the arguments and courier-argunents more than superfictally is Mnossible here, but Dikon's attack on the "radical reactionary feminists" and their reply seens the nost illustrative. 
of re-education through consciousness-raising, socio-political action and internal organizational liberation (Polk 1972). Consciousnessraising begins with personal liberation and expands to include criticisms of the basic institutions and power relationships in the scciety as maledominated and therefore oppressive to women. A goal of consciolisnessraisirg is change in those institutions and relationships, often beginning at a personal level, thus combining the persorial with the political (Firestone 1970:38). Cultural feminists are particularly concerned with being non-elitist, non-hierarchical, and non-competitive internally, believing that "in order to overcome oppression a person must not participate in oppression herself" (Diggs 1972:11). In their groups, they attempt to build "within the Women's Liberation Movement a new form of [non-authoritarian] organization and rew ways of living which dces not import the oppressiveness of traditional male-cominated forms in the societ.y" (Polk 1972:325).

Socialist feminisin (as articulated by Mitchel1 1971, amorig others) asserts a fundamentá correlation besweer capitalism and the oppression of women, and assumes a social or communistic system is a necessary, but not sufficient, precondition for the liberation of women. They view women's oppression as both psychological and ecoricmic, but in both cases consider capitalism as the basic source of that oppression. Therefore, their strategy and tactics emphasize the connection between class oppression and women's oppression, between economic and psychological oppression of women and capitalism. Duxbury and Haeney (1975) state:

An important aspect of feminism is that the personal is the political; every time a weman decides not to enter into a power relationship with either sex, every time a woinan iearns to defend her physical space against assault, that is a political 
statement. But we musi not stop there: we must begin to understand the connection between the sexist institutions of this culture and how they create and perpetuate oppressive sex roles for women and men. Rape of a particular woman is on the same continuum as the rape of Viet Mani or Chije. An individual woman might possibly learn to defend herself against the individual rapist, but she cannot individuaily destroy the ITT conglomerate which has killed thousands in Chile.

Unilike the cuitural feminists, they tend to emphasize the necessity of internal structure and discipline.

However, all three divisions, in one way or another, point to the institutions and practices which support male supremacy and wonen's secondary status--in the economic, political, religious, psychologica?, sociai, ard family realms women are oppressed. To explore all these aspects of oppression is peripheral to the topic under consideration, and therefore this review will focus on the psycho-social institutions and the psychological oppression women face.

\section{PSYCHOLOGICAL EFFECTS OF SEX-ROLE OPPPESSION}

Because an attempt to review the literature dealing with the psychoiogical effects of sex-role conditioning and oppression on women is a thesis ir itself, this discussion will merely attempt an overview of the key ideas (see aiso Bardwick 1972; Hochschild i973; Nadeison 1974; Pierce 1974).5 Feminists begin by criticizing much of the research done in the social sciences and in psychology in paricular for reinforcing the pre-existing sex-role stereotypes "that women are essentially rurturant/expressive/passive and men instrumental/active/aggressive" without analyzing the origins, values and effects of those stereovypes

5 Whistedit (1972) ard Henley $(1973,1974)$ have both compiled extensive bibliographies on women and psycholugy. 
or the researcher's own socially conditioned bias against women (Freeman 1970:1; also Laws kNow; Millet 1963; Silveira 1972). They go on to argue that the characteristics psycholcgy attributes without question to women originate in the socialization process, which in turn trains women to behave in ways which damage tten psychologically, leading Weisstein (1969:208) to conclude that "psychoiogy has nothing to say about what women are really like, what they need and what they want, essentially, because psychology does not know."

One area where wornen have been psychclogically damaged is in their self-concept. Millet (1969) cites studies in which from one quarter to one half of the women admitted they would have preferred to be born inale, with much higher percentages among girl children who, she says, have not yet learned to disguise their true feelings. Freeman (1970:2) discusses studies of women's self-perception showing that women themselves believe in their own inferiority. Among other things, women described themselves as "uncertain, anxious, nervous, hasty, careless, fearful, dill, childish, helpless, sorry, timid, clumsy, stupid, silly, domestic, . . understanding, tender, sympathetic, pure, gererous, affectionate, loving, moral, kind, grateful, and patient." However, self-concept develops if one possesses those attributes that have social meaning, in other words which are labeled and evaluated positively by significant others (Laws Kiow). Women's self-concept, while corresponding to the social stereotypes for women, does not correspond to attributes which have social meaning. Instead, both sexes tend to vălue men and male characteristics more highly than those of wonen (Broveman et a]. 1972; Rosenkrantz et al. 1968 , which in turn mears that women deveiop the ego characteristics 
of other oppressed minority groups (Bernard 1971). Millet (1969:35) explains:

When in any group of persons, the ego is subjected to such invidious versions of itself through social beliefs, ideology, and tradition, the effect is bound to be perricious. This coupled with the persistent though frequentiy suotle denigration women encounter daily through personal contacts, the impression gathered from the images and media about them, and the discrimination in matters of behavior, errployment and education which they endure, should make it no very special cause for surprise that women develop group characteristics conmon to those who suifer minority status and a marginal existence.

Indeed, Millet (1969:57) explains that in the ascribed attributes of both blacks and women common traits are idenifified for both.

Both groups are forced to the same accommodational tactics: an ingratiating or supplicatory manner invested to please, a tendency to study those points at which the dominant group are subject to influence or corruption, and an assumed air of helplessness involving fraudulent appeals for direction through a show of ignorance.

Furthermore, the literature on the psychologicai effects of victimization and on sex differences in young children shows in both victimized minority groups and giri childien common traits of sensitivity, submission, desire for protection, ingratiation, conformity to or identification with dominant group norms, compassion for the underprivileged, passivity and self- and group hatred. Freeman (1970:2-4) concludes that in the results of female socialization, there is "a strong similarity between what our society labels, even extols, as the typical 'feminine' character structure and that of oppressed peoples. . . There seems to be $\bar{u}$ correlation between being 'feminise' and experience status deprivation." Status-deprivation leads to negative self-concept, which in turn leads to psychological deprivation (Dixon 1972).

Not only do women learn to hate themselyes, but they learn to hate other women as we11. Goldberg (1968) gave college women articles 
to read and rate on value, persuasiveness, profundity, writing sty?e, professional competence, professional status, and ability to sway the reader. Half received articies they thought were written by a woman (Joan T. McKay), the other nolf ideritical articles they thought were written by a man (John T. McKay). Goldbery found that if the article was thought to have been written by a womar, it received significantly lower ratings, leading him to conclude that "women are prejudiced against female professionals and, regardless of the actual accomplishments of these professionals, will firmly refuse to recognize them as the equals of their male colleagues" (1968:28).6 Keiffer and Culien (Kivow) found similar examples of intro-punitive responses (in particular denial of membership in the discriminated-against group or aggression against that group) among hostile respondents to a questionnaire about discrimination in academia. Staines, Tavris and Javaranthe (1973) label this the Queen Bee Syndrome, a countemilitancy to feminism they beilieve has roots in a woman's personal success within the system.

In addition to the effects of status deprivation, there is the corresponding psychological debilitation of a constant double bind which exists for women. At its simplist, it is as follows: Women are socialized to behave in certain ways which the culture prescribes and rewards, for women. However, at the same time, those very behaviors are not desirable in and of themselves--in fact they are seen as less desirable and less vaiuable. Steinmann (19\%4) found that while women feel they are balanced between active and passive role behavior, they are conficted because

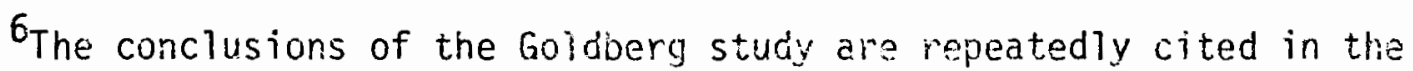
literature, yet the study itself contains certain methodological problems, in particular the utilization of interrelated outcome variables. 
they feel that how they are is not at a11 the "homebodies" men would

like them to be. Bardwick and Douvan (1971:56) explain:

Ambivaience is clearly seen in the simultaneous enjoyment of one's feninine identity, qualities, goals, and achievements and the perceptions of them as less important, meaningful, or satisfying than those of men. . . Society values masculinity; when it is achieved it is rewarded. Society does not value femininity as highly; when it is achieved it is not as highly rewarded.

In other words, the culture regards women for being inferior--"hea?th" consists of accepting a devalued status. If a woman rejects a devalued status (and becomes, for example, a feminist), she is not healthy by the standards of our cuiture.

The work of Horner $(1969,1972)$ cn the effects of women attempting intellectual achievement is an example of this doub?e bind. ${ }^{7}$ Although success is an important mearis of attaining a positive self-concept in this culture, women are motivated to avoid siccess by their fear of the negative consequences of social rejection and role conflict. She writes $(1959: 38)$ :

A bright woman is caught in a double tind. In testing and other achievement-oriented situations she worries not only about failure but also about success. If she fails she is not living up to her own stendards of performance; if she succeeds she is not living up to sccietal expectations about the female role.

Similarly, feminist writers discuss how patriarchy and a consumer society tend to objectify sexuality and convert women into sexuai objects. However, women are not allowed to enjoy the sexuality fated for them but instead are taught to suffer for and be ashamed of that

It must be noted that Tresemer (1973) criticizes Horner's methodology and in his review of the literature on the "fear of success," found that this fear is not at all unique to women, rior is it the only explanation for why people inhibit their own growith. 
very sexuality while nonetheless confined to a sex-bound existence (willett 1963). A woman is used tu reinforne male "superiority" and she in turn quickly learns to use her body as a commodity and to be used as a commodity to get the things she has been taught to want and yalue as well as the thirgs she needs to survive. In so doing, she becomes irretrievably trapped by the double messages inherent in the current societal values which still sanctify the marriage relationship, extol the beauty of sex, virginity and monogamy, condemn the use of sex as a commodity, as a mediun of exchange, and simultaneously hold out respectability, status ascendency, material security and dependency as ultimate goals, by any means. This socialization to be an object rather than a person is compourded by women's prescribed dependency for self-identity on her role as a snother or wife--an identity formed by ariother.

Some carry the consequences still further, suggesting that in order to survive with these basic contradictions ard the anger they engender, women learn to separate out body from mind while continially monitoring the environment ${ }^{8}--j i v i n g$ a kind of "femaie schizophrenia" (Naffziger 1973; Tax 1970). Chesler (1971, 1972, 1973, and as quoted in Feldum, Gabel and Taylor 1973) explains that if a woman attempts to be "healthy" and acts out the feninine role, not oniy is she therefore inmediateiy accepting a definition of herseif as subordinate, but functiona?!y she must be self-deprecatory, dependent, confused, without seli-confidence, live through others, and be objectified sexually. By doing so, nowever,

8Rosenthal et al. (1974) found women more sensitive than men to non-verba? messages and Arithony (1970) argues that this is because women's survival has depended on correctiy assessing the mood of men as communicated through their actions. The work of Hen?ey (KNOit) on the politics of touch supports this. 
she becomes increasingly vulnerable to such self-destructive "femaie" forms of madness as depression (Bart 1971a), frigidity, paranoia, anxiety and suicide attempts (which Chesler argues are just another form for women's learned inactivity and incompetence, in that wornen attempt suicide while men commit suicide). If, on the other hand, she rejects the female stereotype and persists in "male" activities, if she becomes hostile and aggressive rather than depressed, sexually active rather than passive, successful rather than dependent, if she allows herself to perceive clearly and verbalize those perceptions, ${ }^{9}$ she is so frightening both to herself and to society that she is labeled as "mad" until she "reasserts" her fernininity. Madness becomes not a psychological problem but a "sane" response to one's social role.

What we consider madress, whether it appears in :yomen or in men, is either the acting out of the devalued female role or the total or partial rejection of one's sex-role stereotype.

(p. 75)

All this information would lead one to suspect that womer would experience psychological distress out of proportion to their numbers, and there are statistics verifying this imbalance (Fideri 1973). Chesler (1973:79) cites National Institute of Mental Health figures showing that from 1964 through 1968, 125,321 more women than men were psychiatricaliy hospitalized and/or treated on an outpatient basis. Women atso outnumber men in private therapy two to one, and in a random survey of the national population report greater distress than men "in all adjustment areas, in their self-perceptions, and in their marital and parental functions," as well as "more worry tharı men, more fear of breakdown, and

${ }^{9}$ Chesier (1972:88) cites a study in which the majority of foma?e patients reported tha' $\mathrm{men}$ were "persecuting" them. 
more need for heip." Gove and Tucior (1973) similariy found that more women than men are mentally $i 11$, regardless of whether the comparisons are made based on admissions to mental hospitals, treatment by a general physician for mental problems, or community surveys.

Feminists argue that this discrepancy is not mereiy because sex roles damage women psychologically, although the real oppression of women is an important reason. It is also more corventionally acceptable for a woman to be in therapy--women are expected to be weak, depencient and emotion-ridden and thus it is fitting that they would need (or see themselves as needing) the "strength and direction" of a psychotherapist, as Chesler (1972:131) explains:

Many factors . . Would suggest. . a iarge femiale involvement with fsychiatric facilities. For example, the real oppression of women--which leads to real distress and unhappiness; the conditioned female role of help-seeking and distress-reporting-which naturally leads to patient "careers" as well as overt: or subtle punishment for such devalued behavior; the double or masculine standard of mental health used by most clinicians . . ; the comparatively limited social tolerance for "unacceptable" behavior among women--which leads to comparatively great social and psychiatric pressure to adjust--or to be judged as neurotic or psychotic; . . . and finally, the female nature of the psychotherapeutic and hospital institutions--which leads to their being accepted more easily by women than by men.

The following two sections will discuss those feminist arguments that the field of mental health contributes (some say particularly) to the psychologicâl oppression of women.

\section{FEMINIST CRITIQUES OF FREUD}

Within the fields of mental health, psychology, and psychotherapy, a particuiar focus of feminist criticism is Freudian psychotherapy, specifically its assumptions and theories about wonen. Miliet (1969:178) 
has described Freud as "beyond question the strongest individual counterrevolutionary force in the ideology of sexual politics during the period [of the sexual revolution]." Much of the feminist literature argues that his ideas have served to crystallize the feminist mystique (Friedan 1953), Justify male chauvinism (Gi]man 1971), heighten the split between mind and body (Mander 1974), perpetuate unwarrented myths about female sexuality (Sherfy 1966) and reinforce the authoritarian hierarchy of the nuclear family (Marder 1974; Seidenberg 1971). However, it is not so much that freud was a male chauvinist-history and psychology have produced others before and since--but that his chaisyinism was manifested in his theories, which have been used by those who followed him to further maintain their own mythologies. As Marder (1974:39) explains:

I have criticisms of Freud's original out?cok and writings, but mostly what I am critical of and concerned with is the social mythology that has become "Freudian psychology" in our culture, as it is practiced in the riinds of famiiies, advertisers, industrial consultants, and psychiatrists and psychologists day to day.

Feminist criticisms of Freud center on two of his basic assumptions-that anatomy is destiny and that sex is unrelated to power--as played out in three of his central constructs--penis envy, the Oedipal complex, and the idea of clitoral-vaginal transfer of female sexuality. 10

10Mitche11 (1974) argues that Freud has been misinterpreted by his feminist critics who, she feels, have studied his writings devoid of their context within the main concepts of psychoanalysis. Firestone (1970), while in agreement with some of these feminist criticisms of Freud, argues that if reanalyzed within a feminist context, Freud rias valuable insights for feminism because he grasped what she sees as the crucial problem for modern life--sexuality. Firestone reinterprets the Oedipus compiex as follows:

From the begirning [the boy child] is sensitive to the hierarchy of power [in the family]. He krows that. . he is compietely 
As a biological determinist, Freud assumed that a woman's sexual organs (or lack of them) had inherent and intrinsic affects on her ultimate personality development. Many feminist writers argue that his perspective ignores the impacts of society on personality development. Generaily, what is at issue is rot Freud's observations, but rather the interpretations ard prescriptions for feminine character he based on those observations. The women Freud saw were the "unadjusted" wornen of their time, those dissatisfied with the role of the Victorian woman and envious of the power and freedoms of men. However, rather than understanding this dissatisfaction as arising from the social situation which was for women in fact self-limitirg, anger-inducing, inferiorityinvoking and sexually repressing, Freud substituted the symptom for the cause. Thus feminists reject the notion of penis-envy, arguing that it is not the penis itself which is enviable but the power the penis represents (Gilman 1971; Mander 1974; Millet 1969). De Beauvoir (1952:44)

dependent on .. . his two parents. . . Between the two of them, though, he will certainly prefer his mother. He has a bond with her in oppression: while he is oppressed by both parerits, she, at least, is oppressed by one. The fatiner, so far as the child can see, is in total control. . . . At the age of six,. . . suddeniy now he's expected to identify with this brutish stranger. Of course he doesri't want to. He resists. . . [However, j most children aren't fools. They don't want to be stuck with the iousy iimited lives of woinen. . . But it is hard. Because deep down they have a contempt for the father with a.1! his power. They sympthize with their mother. But wha: can they do? They "repress" their deep emotional attachment to mother. . . It is no worider that such a transition leaves an emotional residue, a "complex." The male child, in order to save his own hide, has had to abandon arid betray his mother and join the ranks with her oppressor. (pp. 46-52)

In a third reinterpretation, Torrey (1971) posits the existence of patriarchy on men's inability to bear children and their need to achieve legitimate paternity. 
writes that "the phallus assumes such worth as it does because it symbolizes a dominarice that is exercised in other domains." Similarly, Millet (1969:247-8) describes the Oedipus complex as "rather less a matter of the son's passion for the mother than his passion for attaining the ievel of power to which adult maie status is supposed to entitle him." Freud's definition of mature sexuality as transfer of erotic focus from the clitoris to the vagina and his definition of frigidity as woman's failure to have vaginal orgasms is seen as a definition of women "iri terms of what pleases men" (Koedt 1971:168). From these three constructs-peris envy, the 0edipal complex, and the transfer of female sexuality... Freud developed his theory of the personality of women.

However, feminist criticism of Freud runs deeper than the erroneousness of these three ideas. Underneath the theories and the constructs they point to Freud's radical bias against women--in other words, his sexism. Freud does not see the "normal" wonian as different from man in any positive sense because she is already by definition a-normal when compared to the maie standard of normality and because she is already by his definition inferior when compared to the male's superiority. Feminity is for Freud the absence of masculinity; but since masculine traits are the approved-of traits, the presence of feminity is always ultimately negative. Thus, he describes women as passive, masochistic, rarcissistic, jeaious, suffering from seifcontempt, opposed to civilization, less intelligent, less ethical, iess judicious, psychologicaily rigid, often sexully frigid, and tending toward hysteria (Yurmark 1972)---as Ash (1971:325-6) concludes, "a sour, disappointed, envious, castrated male." 
Freud. . emphasizes that women come into analysis looking for a penis as well as relief from symptoms. They leave analysis perhaps improved a great deal but unreconciled to the fact that they can't achieve a penis. I wonder. Is it that womer come into analysis looking for a feeiing of self-worth, one might say an honorabie identity, which they think is a mascilline identity? Do they leave analysis not having found a satisfactory feninine identity because for the male analyst, too, the oniy honoraide identity is a masculine one?

Eariier feminist writers (De Beauvoir 1953; Freidan 1309;

Shainess 1969) expiain Freud's misunderstandings of women as unconscious perpetrations of his own cultural imprisonment and the rationalizations of his cwn unacknowledged fears and resentments. More recent feminist writers believe that Freud's oversights wore not mere naivete. They point to his repeated condescending barbs against those feminists who criticized him, and his continual refusal to take their arguments seriously despite a changing cultural climate which was giving increasins credence to their views. Freud's hypotheses, they argue, are "weighted with expedient interest" for only with such a perspective could he maintain his "gross male-supremicist bias" (Mander 1974; Miliet 1969: 182-7). By ascribing pejorative terms to women Freud was merely justifying--not explaining--the cultural norms of his own society; by sanctifying male supremacy he was in essence sanctifying himself: by giving credence to the Oedipal situation he was maintaining his own familial position. For Millet (1969), this is the essence of sexuai politics.

What Freid did, ultimately, was justify and sustain the status quo. His theories sanctified the oppression of women because within his system all alternatives were labeled "neurotic." All those characteristics which Freud attributed to women in turn have perpetuated their 
secondary status when used as patronizing rationales for ignoring women's perceptions of their reality. Freud began with descriptions of the women around him, descriptions often based on observations of accuracy and sensitivity. However, what he did was declure that what he saw was inevitable, and in so doing, his descriptions became prescriptions, forcing women to adjust to an ir.terent?y unhea?thy position, to accept a subordinate role, and to submit to an inferior fate.

Also criticized are those followers of Freud who accepted andior expanded upon his position on women adhering to a mascuitine model of personality: Deutsch for her pejorative cataloging of anatomicaliy determined "feminine" traits; Erikson for his theory of "inner space" as the counterpart of male externaijty, his naive "experinents" with towers and fortresses, and his insistence on generation as the criteria for mature female identity; and Reik for his crassness, insensitivity, and contempt for women, among others (Barrett et al. 1974; Brogan 1972; Doherty 1973; Fields KNOW: Firestone 1970; Mander and Rusti 1974; Millet 1969; Waistedt 1971; Wesley 1975; Yurmark 1972). Schwartz (1973) illustrates how social work curriculum to present a sexist viem of women. Chesler (1972) presents overviews of the work of Reich, Laing, Cooper and Ssasz, finding that none of them have a frame of reference in which what is human is also female. 11

It is on the cumulative basis of all this misinterpretation, distortion, and justification for the continued subordination of women that some feminists came to repudiate psychology altogether.

13 Mitchen (1974) is critical of both Reich and Laing, but less fon their positions on women per se than what she sees as their misunderstanding of Freuc and their misconceptions of the anconscious. 


\section{FEMINIST REPUOIATION OF PSYCHOLOGY AND PSYCHOTHERAPY}

In the early 19705, a number of articles appeared lambasting the institutions of psychology and psychotherapy (and all related fields) from a feminist point of view. Chesler's Women and Madness (1972) is the classic work, but others advanced similar views (Etzkowitz 1971; Gardner 1971; Hartman 1970; Redstockings 1971; Rush 1971; Waistedt 1971; Webbink 1972). Basically, they argued that the field of psychology as a whole has not only failed to understand women but has actually contributed to their oppression. The basic thesis is two-fold.

First, psychology, and in particular, psychotherafy, does not acknowledge the consequences of societal demands and discrimination upon women and therefore does not focus on changing the causes of womien's emotional distress in the society. Instead, they assume there is something wrong within individuals, labeling their symptoms "reurotic" or maladjusted and encouraging women to take personai biane and responsibility for their unhappiness. In esserice, it is demarding that a woman adjust herself to the socioty, as Chesler (1971:746-52) explains:

Women's unhappiness is viewed and "treated" as a problem of individual pathology, no matter how many other female patients (or non-patients) are similariy unhappy. . Woman's inability to adjust to or be content by feininine roles has been considered a deviation from "natural" female psychology rather than as a criticism of such ro]es. . . Esychotherapy . . . enable[s] women to safely express and defuse their anger by experiencing it as a form of emotional iliness, by translating it into... frigidity, chronic depression, phobias and the like. Each woman as patient thinks these symptoms are unique and are her own

fault. She is neurotic, rather than oppressed.

Thus, clinicians attempt to bring their patients to terms with the female role. However, adjusting to that devalued roie inerely perpetuates the double bind women experience, which in turn brings its owin emotional 
"madness." At the same time, adjustment for women to the feminine sex roie stereotype aiso means that they manifest those behaviors clinicians label merital illness.

This is the "adjusiment" notion of mental health, the idea that one must "'adjust' to the specific racism or sexism that limits one's potential fron the beginning" (Firestone $7970: 64$ ). If a person becomes too angry, she is labeled mentally ill even though "it may be an indication of mental health to feel a natural anger toward [one's] oppressor" (Bonetti 1974:29-30). As Heide (KNOW:3) explains, "Adjustment psychology and psychiatry help keep people 'in their place,' when it is really the 'place,' rather than the people, that should be changed." Accordingly, some feninists argue that therapy not only encourages adjustment to an unhealthy society but defuses women's collective energy into futile attempts to heal oneself individually. Some point to the sturies showing the ineffectiveness of therapy (Firestone 1970; Tennov 1973), but most explain that therapy is merely an individual solution which cannot offect the larger social structure. "In all fairness to therapy, it is sometimes necessary, but it is limited in that there is always the same sexist society to which we return where limited roles are imposed upon us as women" (Leah and Mary Jane 1971:52). These authors also criticize the fee structure of therapy for reinforcing the values of the culture.

All too often the therapist and particularly the psychoanalyst are avaliable only for the few who can afford them. Freud, in fact, insisted that only by paying would the patient be able to take analysis seriously. This is a notion totally in keeping with a culture that values money and individual achievement above the bettement of many.

(p. 52) 
Yurmark (1972) studied sociai casework literature on women and their role from 1920 to 1950 and found writings in social work texts and journals consistentily supporting and building upon Freudian psychoanalytic theories and prescriptions. She concludes:

With few exceptions, psychoarlalytic theoretical perspectives of women have not been challenged as a basis for social casework's theory of human behavior. . . As seen through a study of its literature on women, social casework changes focus with the times, with prevailing vaiues and mores, rather than examines values and/or questions them. As the society changes, so changes social casework. From this, one might reach the conclusion, that in relation to the role of women, social casework is an agent of social control, rather than an agent of individual growth.

(p. 53)

This idea of psychotherapy as a means of social control (or at the least, maintenance of the status quo) by focusing on woman's adjustment to an unhealthy society as the oniy alternative to "mental illness" is echoed by Anthony (1970), Gardner (1971), the Association for Women Psychologists (1970), and Becker and Krakauer (1973), among others. Secondly, feminists find the psychotherapeutic relationship itself oppressive to women. In part, this has to do with the power imbalance in the relationship itself, in which the therapist is dominant and the client subordinate (Silveira 1972; Tennov 1973). "The institution of . . therapy is a patriarchical one--regardless of whether the individual clinician is female or male" (Chesler 1972:120-i21). Tennov (1973) carries the argument one step further, asserting that a professional cannot be a feminist. "Psychotherapy and Sisterhood are basically antagonistic to one another, and . . a woman who 'treats' another woman is not her sister." (See also Agel 1973:67-86.) Chesler (and others) explain that the rower imbalance is particularly entrenched when psychotherapy teaches a women to talk rather than act, further conditioning her 
into helplessness and dependency and guaranteeing she vill remain in a secondary status, and when the therapist, remaining unknown, is thereby expected to be or perceived to be objective. "Our culture's criteria for an 'expert' are the sanie for engineers and soul-healers: objectivity, rationality, impersonality" (1972:121). However, Chesler argues that in actuality the therapisi is not at all objective and in fact controls what the client says through a subtle system of non werbal rewards and withheld responses made in congruence with his or her own conscious or unconscious values.

This authority is complicated if the therapist is male, and given the disproportionate number of male as versus female clinicians, it is highly likely that the therapist will be a male. Chesler cites studies which report 90 percent of all psychiatrists to be males, psychologists to be male two to one, and only social workers (the profession with the least prestige and the iowest pay ${ }^{12}$ ) to be predominantly females, in a two to one ratio. Because a woman in psychotherapy is so often in a relationship with a male, she concluries (1971:746-51) that the same dominant/subordinate roles of male and female that exist in the society and are played out in marriage will be played out in the therapeutic relationship.

For most women the psychotherapeutic relationship is just one more instance of an unequal reiationship, just one more opportunity to be rewarded for expressing distress and to be "helped" by being "expertly" dominated. Both psychotherapy and marriage isolate women from each other; both emphasize individual rather than collective solutions to woman's unhappiness; both are based on a woman's he? plessness and dependence on a stronger male authority figure.

12 Adanis (1971) describes how women are socialized into the compassion trap, and draws the anlology between the roles of women and the professional roles of socizi workers. 
For a woman seeing a male therapist, the authority is doubled: the therapist not oniy has the authority of his therapeutic role, but has the authority of his sexual role as well. A woman in therapy is subordinate when it comes to confronting or challenging either. To mistrust him as a man can become only further manifestation of her "paranoia"; to want to know that one's problents are problems shared by all women can be calied "escapism"; to be angry at his sexism or at the system that oppresses women can be dismissed as transference. ${ }^{13}$ Thus, Chesler (1971:757) concludes that male therapists cannot work with women.

Male psychologists, psychiatrists, and social workers must realize that. . . they know nothing about women; their expertise, their diagnoses, even their sympathy is damaging and oppressive to women. Male clinicians should stop treating women aitogether, however much this may hurt their wallets and/or sense of benevoient authority. . . . [As a power-structured relationship, I I wonder how well such a structure can encourage independence--or heaithy dependence--in a woman. I wonder what a woman can learn from a male therapist (however weli-intentioned) whose own values are sexist? How free from the dictates of a sexist society can the female as patient be with a male therapist?

Finally, anong feminist criticisms of psychotherapy as practiced by maie therapists with female clients come the "horror stories," the accounts of women confronted with sexually seductive therapists while they were extremely psychologicaliy vulnerable and repeatedly told if they questioned or protested that the problem was not with the therapist but with their projections and emotional conflicts (Anthony 1970; April

13 In the 1iterature, a number of articles by feminists stress the reality-base of women's anger and encourage wornen to refuse to allow their anger to be labeled "unhealchy" or paranoid and instead to appreciate it, express it, and utilize it (Bernard 1971; Christeve 1974; Kaplow 1971; Mailhot 1973). As Bart (1974) says, "We no longer blame ourselves for nur troubles. For although we are angry, we are no longer mad." 
KNOW; Barrett ett al. 1974; Chesler 1972; Fields KNOW; Miller 1971; Waistedt 1971).

In their repudiations of psychology and psychotherapy as yet two other institutions which oppress women, feminists point to the research on the attitudes of clinicians about women and ways those attitudes are incorporated into therapy--described often as the "doub?e (or masculine) standard of mental health." As Chesler (1972:127) says:

Since clinicians and researchers, as well as their patients, adhere to a masculine standard of mental health, women, by definition, are viewed as psychiatrically impaired-whether they accept or reject the female role--simply because they are women.

VII. RESEARCH REGARDING THE DOUBLE STANDARD OF MENTAL HEALTH

Experimental research supports the accusations of ferninists that clinicians devalue women. The research in this area most frequently referred to is that of Broverman et al. (1970), but more extensive replications by Fabrikant (1974) and Nowaki (1973), as well as a similar study by Neulinger (1968) obtained similar results. In the Broverman study, a questionnaire consisting of 122 bipolar items (i.e., Very Aggressive / Not at a 11 Agressive; Doesn't hide emotions at all/Always hides emotions) was developed and each item tested for agreenent as to sek-role stereotype and social desirability (Rosenkrantz et al. 1969). The questionraire was administered to 79 clinically trained psychologists, psychiatrists and social workers. All were sent the same questionnaire, with one of three sets of instructions. One grour was instructed to choose the poite on each item to winich a mature, healthy, socially competent adult man would be closer. The second group was given similar 
instructions, except "aduit wcman" yas substituted for "adult man," and the third group was simply instructed to describe a healthy adult. In analyzing the results, two important conclusions were found. The first was that the clinicians described healthy men differently from healthy women, and further that their judgments paraliei stereotypic sex-role behaviors and socia? desirability (i.e., they ascribed male-valued sterectypic traits more often to healtiny men than healthy women). This finding, they argue, conceals a powerful negative assessment of women.

Clinicians are more likely to suggest that healthy women differ from healthy men by being more submissive, less independent, less adventurcus, more easily inîluenced, less aggressive, less competitive, more excitable ir minor crises, having their feelings more easily hurt, being more emotional, more conceited about their appearance, less objective, and disliking math and science. This constellation seems a mosi unusual way to describe any mature, healthy individual. (pp. 4-5)

The second major finding was that while there was no significant difference between the adult and masculine concepts of health, there was between the adult and female concept. They conclude:

These results, then, confirm the hypothesis that a double standard of health exists for meri and women, that is, the general standard of health is actually applied only to men, while heal thy women are perceived as significantiy less healthy by adult standards. . . . Thus, for a woman to be healthy, . . She must adjust to and accept the behavioral norms for her sex, even though these behaviors are generally less socially desirable and considered to be less healthy for the generalized competent, mature aduit.... [This] then places women in the conflictual position of having to decide whether to exhibit those positive characteristics considered desirabie for men and adults, ard thus have their "femininity" questioned, that is, be devalued in terms of being a woman; or to behave in the prescribed feminine manner, accept second-class adult status, and possibly live a lie to boot.

(pp. 5-6)

While they do not suggest that clinicians alone pose this dilemma for women, it does seem that clinicians do accept the sex roie stereotypes 
and by so doing, help perpetuate them.

Similarly, Abramowitz and Abramowitz (1973a) found that non-liberal counselors imputed greater maladjustment to left-oriented politically active females than to an identically described male client.

Overall, the results of the inquiry implicate the assessor's political opinions as a potential source of bias in his clinical decisions. That the target of the bias was a left-oriented politically active woman supports the contention of Szasz and others that certain mental health activities may serve to unfairiy stigmatize persons whose behavior or values pose a challenge to the dominant mores. . . It raises the specter of covert discrimination against the "liberated" woman, unintentional though it may be, on the part of certain workers holding unsympathetic socio-political views.

(pp. 388-89)

Schlossberg and Pietrofesa (1973) review several studies on counselor bias and find counselors rate traditionally feminine (i.e., conforming) career goals for female clients more appropriate than traditionally masculine (i.e., deviate) career goals and find female clients with deviate goais in more need of counseling than those with conforming goals. The literature is less clear about whether or not it is only male clinicians who hold to a masculine standard of mental health. Broverman et al. (1970) found no significant differences between maie and female clinicians in their study. Abramowitz and Abramowitz (1973b) found that a woman client's psychological status was judged more sternly by female than male counseling center personnel. In contrast, in the literature reviewed hy Schlossberg and Pietrofesa (1973), male counselors generally held the stereotypic views. Female counselors gave higher Acceptance scores to both deviate and conforming clients than did male counseiors. Female counselors also described their ideal woman as more extra-family oriented than the ideal projected by the men (who aiso suggested that career women are less attractive to men) and rejected the intra-family- 
oriented idea? more strongly than men did. Male counselors associated college-bound giris with traditional feminine semi-skilled occupations while female counselors perceived the college-bound girl as interested in occupations requiring a college edication. In their own study, however, female counselors were as biased as male counselors against women entering a masculine career (engineeriny). Similarly, Haan and Livson (1973) found fellale psychologists to ascribe more favorable characteristics to females than did male psychologists.

\section{MENTAL HEALTH FIELD RESPONDS TO FEMINISM}

As the literature cited above began to appear in the media, and, slowly, in various academic journals and as the country as a whole began to feel the impact of the feminist movement, beginning in 1971 and increasingly in the years following, the mental health field began to respond to feminism and to the critiques feminism made of it. The titles of articles themselves are revealing: "The Mental Health Movement Meets Women's Lib" ("Special Symposium . . ." 1971); "What Psychiatrists Say About Women's Liberation" (Cummings 1972); "Psychoanalytic Reflections on Women's Liberation" (Moulton 1972); and "Implications of the Women's Liberation Movement for Psychotherapy" (Rice and Rice 1973), among others. As would be expected, these articles run the gamut from those who labeled the feminist movement misguided and/or paranoid to those which encourage psychotherapists to apply the messages of feminism to their practice.

Among those in the former group, there were criticisms of feminists themselves, refutation of their theoretical positions, and espousal of 
the strengths of psychotherapy. While some acknowledge certain gains that the women's movement had achieved, particularly in areas of legal reform, there is a focus on the damage done to many women by the more "militant" members of the movement, who they characterize as misguided and going "overboard" in a "blame syndrome" which confuses women, arouses their often-misdirected anger, and antagonizes the public, thereby polluting efforts to secure reforms. One psychiatrist lquoted in Cummings 1972) said:

This illusion that you are right and the fault is in someone else comes very close to merital illness. I'm not saying advocates of Women's Lib are mentally ill, just that there is a definite paranoia that runs through some of the thinking.

They deny that psychoanalysis has "put down" women or had as a goat adjustment to society's norms (Rolphe 1972; Seeman 1973).

Secondly, they disagree with many of the theoretical positions of the Feminist Critique. Rolph (1972) characterizes the feminist dismissal of the clitoral-vaginal transfer theory by pointing to the absense of sersation in the vagina as "a half-truth distorted for political ends." They feel that feminists disregard or distort valid and important biological differences (Beesley 1973; Moulton quoted in Cumnings 1972; "Special Symposium . . ." 1971). Ro110 hay (quoted in Cummings 1972) writes that the idea of equality of the sexes "is clung to at the price of denying not only biological differences, which are basic to say the least, between men and womien, but enlotional differences, from which comes much of the delight in the sexual act." Seeman (1973) and Shainess (quoted in Cummings 1972) both stress the importance of the mother-child symbiosis, and Seeman also believes that little girls do fee $i$ envious of the boy's urination abilities, an envy which if 
channelled can lead to such "achievements" as the Women's Liberation movement itself. She cautions agairst too much self-scrutiny on the part of psychotherapists if $i t$ means they lose sight of such old but valid truths. Finally, she suggests that since women have entered into a massive crisis of identity, perhaps psychoinerapy would do well to adapt the attitudes and techniques of adolescent psychiatry to the psychotherapy of the role-questioning woman.

Sone of those who were less critical of feminism, emphasizing the importance of feminism to women, are however concerned by its hostility towards men, what Moultion (1972) calls this "venting of rage against men in a blind, diffuse manner" which merely perpetuates the estrangement of inen from women and further polarizes the sexes. Symonds (1972:227) describes this as "one of the neurotic aspects of women's Tiberation":

Another type of reaction in the women's liberation movement has been to express intense hostility, even hatred towards men. For some this hostility is felt as valid goal in itself. They feel justified and righteous in their anti-male feelings, not realizing that this in itself is an expression of their continued, self-imposed dependency. . . A neurotically dependent person feels heipless and hopeiess about ever being strong enough to stand alone. The only thing he or she can do with impunity is to blame his caretakers for not taking care of him in the right way. We sometimes call this "hostile dependency" or "morbid dependency." That is the quality of some of the feminist literature I have seen, and that is the message of some spokeswomen for the women's 1iberation movement.

They stress that not only women but both sexes are oppressed by sex roles and need to work together to achieve the liberation of all people from sexual roles. Moulton (1972) discusses how the ambivalence men have toward women is an important issue in their analysis. Stevens (1974) feels that the "problem is not simply that wornen have been denied their 
assertive, intellectual seives; it is also that men have been denied the opportunity to develop their dependent emotional selves." As a woman therapist struggling to move out of prescribed roles herself, she feels she can be particularly heipful to such men.

Within the literature, there is a third group of articles which, while never using the term "feminist therapy," takes a clear position of advocacy for the women's movement and attempts to explain the feminist critique of society and psychotherapy, suggesting training and practice alternatives for clinicians (Barrett et al.; Ccok and Stone 1973; Rice and Rice 1973; Stephenson 1973; Stevens 1971; Wesley 1975). These writers emphasize that the critical thing is for clinicians to acknowledge the impact of the social context and become sensitive to the psychological effects of sexuai roles and their own sexual biases, perhaps participating in consciousness-raising groups themselves. They argue that no matter how hard the therapist attempts to be neutral, one's attitudes and values are communicated in subtle and uncontrollable ways. Stevens $(1971: 14-75)$ explains:

Insofar as a therapist accepts society's role prescription for women, he is implicitiy accepting the value judgment that underlies it: that women are basically incerior to men. . . This attitude will permeate his whole stance--the areas in which he seems most interested and on which he chooses to focus, his demcanor, tone of voice, posture, and the most minute facial expressions. . . Thus even when no specific role conflicts are at issue in therapy--when "women's issues" are never mentioned--the therapist's unconscious attitude toward his patient is to some extent antitherapeutic... . [and] he cannot help her to develop her human potential.

In other words, they reject the idea of therapeutic neutrality, arguing that in any theoretical orientation there are ciear values (Brogan 1972). Bart (1971b) calls this the myth of a value-free psychotherapy. Stevens 
(1971:15) stresses that since vaiues are communicated to clients in one way or another and clients in turn model after the therapist and incorporate their values, therapists should acknowiedge their values to themselves and directly communicate them to their clients.

By the time a [woman] staris therapy, she has introjected many... destructive stereotypes. . . This means that the therapist must frequently watch for rints of intellectual and societal strivings that have long been repressed and denied.

Many therapists believe that the therapist must not impose values on his patients. If a patient is happy being exclusively a wire and mother, the therapist must not challenge her because he feels that a woman cannot be fulfilied in these roles. Thus watching for hints of frustration is interpreted as imposing values on a patient. This author believes that concern about imposing values is a diversion from the real issues invoived. . .

The value judgment underlying [women's liberation] is that women have as much potential and inner worth as men. This author wants to impose that vaiue judgment on her patients since one of her major goals is to enhance the patient's selfimage. . . [ [and believes that] it is incumbent on [a11] therapists to examine and acknowledge their values instead of to pretend a nonexistent neutrality.

Rice and Rice (1973) explain the importance of the therapist recognizing that the generalized hostility many women feel toward men, including the male therapist, is a natural result of increased awareness and cannot be merely interpreted as transference.

Since it is likely that male therapists (as a product of our society) share certain chauvinistic attitudes at present, part of a woman's greater feelings of hostility toward men, including her therapist, seem appropriate and justified. Such feelings should be honestiy acknowledged and dealt with in the therapeutic relationship.

(p. 192)

In this as in other areas, they stress the importance of clinicians not labeling role conflict as psychopathological and interpreting it in intra-psychic terms but rather viewing it as healthy and encouraging women to question, even though doing so may threaten the therapist's elevated social power. 
A more fruitfui therapeutic course would be to help a woman guestion, probe, and recognize the historical, environmental, familial, and societal antecejents that can of ten precipitate and perpetuate feninine confijicts; aid her with the restructuring process riacessiry in her frimary and personal relationships, especiaily her marriage; provicie a place where feelings toward men and about worien who stand for the traditional feminine role patterns can be yentilated and explored; and assist her in exploring new roles and modeis. (p. 193)

In other words, rather thar the traditional blank-screen, silent approach of the analytic mode which a number of writers feel merely reinforces the behavior patterns of regression, dependency, and distortion already distressing women or the non-judgmental client-centered approach which they feel fails women who come to therapy aiready goal-less, lacking inspiration and information, they suggest that the therapist be a knowledgeable, active porticipant in the therapy process. In this role, the therapist would directly communicate her values to her clients, support a voman's questioning of sex-role stereotykes and her attempts to change her social situation whether personally or politically, sanction intellectual and social assertiveness, openly advocate alternative life styles and roles, confront women who have introjected destructive visions of the traditional feminine role, educate women clients about crisis situations of life cycles such as marriage-career conflict, abortion, menopause and widowhood, and, recognizing that psychotherapy is not aliways the answer, refer women to consciousnessraising groups and work themselves as community change agents (Barrett et a1. 1974; Rice and Rice 1973; Stevens 1971; Tiedt 1972).

One issue discussed is whether a male therapist can even work with women, a concern Schwartz (1974) found notably overlooked in social work literature. Carter (1971) uses what are in essence traditiona? 
stereotypes to argue that a woman's developmental experiences, which have taught her to be emotionally responsive, nurturing, and understanding, make her the better choice for certain types of clients. Others, however, expiain that the important thing is for therapists to understand that based on worlen's experience, they perceive men not to understand women and therefore that there are distinct advantages at this time for women therapists to work with women clients because of a woman therapist's greater sensitivity to issues, her ability to emphathize with a woman client's feelings and experiences, the client's greater willingness to explore sexual issues with a female therapist, the therapist's provision of a positive female role model, and her ability to offer solutions from her personal experience (Barrett et al. 1974; Krause 1971; Kronsky 1971; Rice and Rice 1973; Trout 1973). However, some point to the research showing that many women therapists hold to stereotypic views of women as strongly as men do. Fabrikant (1974) found that female therapists cisagreed with the ferinist argument that women work better with women, while Lazarus (1974) argues that there-are some situations in which a male therapist is preforabie to a female one for women.

Women, as a particular group and with particular problems, began to receive more attention in the literature, sometimes with an accompanying analysis of societal impacts on their symptoms and other times merely stating new research and/or new techniques in the psychotherapy of women. Krause (1971) and Moulton (1972) discuss their work with neurotically dependent women, a problem Krause labels the "femininity complex": women who have internalized the patriarchal ideal of womanhood. Schlossberg (1972) explains that women have been limited in their 
decision-haking potentialities because of societal conditioning and suggests a change agent inode? for counseling that supports a woman in Expanding her scope of choices, enables her to make decisions, and helps her to implement them. She explains that there is a delicate balance between using consciousness-raising to free women to see expanding options for themselves and imposing one's views on the counselea. Pincus, Radding and Laurence (1974) describe their development of a counseling service for women, focused particularly on career counseling. Meador, Solomon and Bowen (1972) and Whiteley (1973) experimented with therapy groups for women oniy, finding that without men women discarded superficial role behavior and talked differently about those things most important to them. Similariy, Barrett et al. (1974) advocate women being in all-women groups to break down women's isolation from each other and provide new self-definition based on an awareness of the social source of one's problems.

Proceeding from a modified Freudian base, Kronsky (1971) presents a psychoanalytic model for dealing with women's self-assertive strivings and the guilt thereby engendered in which she communicates an explicit attitude of acceptance and support for women's desires for seîrassertion as primary rather than as derivitive from competition with men, even if this means she contradicts the biases of other therapists (see also Menaker 1974). Gutier (1973), Cummings et all. (1974), Gilmore (1973), Jakubowski-Spector (1973a,b) and Withers (1975) deal with the issue of wonen's self-assertion much more from a learning theory model. Butler explains the differences between the assertive problems of men and women, with women having particular problems in 
expressing negative feelings (disagreeing and expressing anger) and in nonapologetically expressing competency, power and authority. Women have received negative societal reinforcements for self-assertion, and in turn learned to punish their own assertive behavior. Gilmore finds depression to be a result of this sub-assertion. JakubowskiSpector explains that at this time it is women who are demanding assertive training, and has developed a model which combines a stimuius filn with behavior rehearsal.

Fodor (1974a,b) includes assertive training in utilizing a behavioral approach in the treatment of women's sex role conflicts and accompanying symptom formation. She explains that even when cases were not originally perceived as sex roie conflicts, when reevaluated this is often seen to be a core issue, and gives examples of conflicts around achievement, phobias centered in leaving home and becoming indeperdent, depression, and sexual problems, stressing the societal learning that accompanies the development of all these problems for women. In addition to traditional behavioral techniques, she emphasizes the value of modeling by an independent female therapist who shares her owr experiences with the client. Burtle, Whitlock and Franks (1974) focus on female alcoholics, utilizing a behavioral approach to extinguish maladaptive guilt and restore self-esteem. However, while these techniques enabled them to promote guilt-free self-perception in 12 hours of hehaviorai treatment, these gains were eradicated or diminished after 16 weeks in the community, emphasizing the critical role of societal reinforcement on behavior. Beck and Greenberg (1974) present a model of time-linited cognitive therapy for depressed women. 
Barbach's (1975) work with.pre-orgasmic women ${ }^{14}$ views the presence of a sexual problem as an issue of learnirig and practice and has developed a group treatment model which incorporates a structured masturbation progran in the context of group discussion, psychological information about feriale anatomy and sexuality, and homework exercises. Results are dramatic: 93 percent of the women who completed the program were consistentiy experiencing orgasin, usually through self-stimulation, five weeks later, a change which led to other changes in their attitudes and feelings about themselves. The group modality seems a critical aspect of this success, for the sharing that occurred broke down individual isolation and confusion and fostered support and insight.

In the early $70^{\prime} s$, various professional journals put out special issues focused on women and sexism (i.e., American Journal of Orthopsychiatry, October 1971; American Journal of Psychiatry, October 1973; American Journal of Sociology, January 1973; Courseling Psychologist, No. 1, 1973; Journal of Marriage and the Famiiy, August 1971; Journa 1 of Social Issues, No. 2, 1972). In the years following, books began appearing focusing on women's emotional distress and various treatment approaches. Examples include Franks and Burtle's Women in Therapy. $(1974)^{15}$; Heissman's The Depressed Woman (1974); Osborne and Harris'

14 In another article Kerr (1975) câlls this "feminist sex therapy," but it is not included in the section of this chapter on feninist therapy because its focus is specifically limited to sexuality.

15 perhaps one of the most comprehensive anthologies in the field to date, it includes, in addition to works cited elsewhere, articles on therapeutic approaches to wanen historicaily (Osmond, Franks and Burtle), on women in institutions (Howard and Howard), on therapy with lower-class women (Siassi), on a Gestait therapist's view of women in therapy (Polster), and on female homosexuality (Riess). 
Assertive Training for Women (1975); Matthews at al. 's Counseling Girls and Women Over the Life Span (1972); as well as several collections of articles on psychoanalysis and women, in particular Women in Analysis edited by Strouse (1974) and Psychoanalysis and Women, edited by Miller (1973). Again, however, aside from the work of Kronsky (1971) discussed above who speaks of the "fenirist-oriented therapist," these works only imply what feminist therapy would be.

\section{THE FEMINIST MOVEMENT IN SEARCH OF ALTERNATIVES}

Concurrently the feminist movement itself, ${ }^{16}$ at least as indicated by the literature, semed to move beyorid attacks on Freud and traditional psychotherapy (winich at a certain point seemed taken for granted) into â quest for alternatsives (Malone 1971). one suggested that consciousness raising could be an alternative to therapy for women (Brosky 1973; Eastman 1973; Hanisch 1970; Kirsch 1974; Walker kNOW; Zweig 1971). As Bonetti (1974:10) explains:

In effect, a successful consciousness-raising group is therapeutic to the extent that women understand that their condition is political, women experience the personal growth and individuation that also happen to be objectives of psychotnerapy.

Gerson (1974) used the model of the consciousness-raising group in work with 4 th and 5 th grade girls. 0thers, frustrated with their experiences in consciousness-raising groups or dubious from hearing of them from their clients, criticized consciousness-raising for its inability to move beyond individual liberation to collective liberation, beyond

16Those articles included in this section as feminist alternatives are distinguished from those in the previous section (as responses of the mental health field) by where they were located (i.e., alternative vs. academic or "established" press), and/or their fccus (i.e., feninism as vs. therapy). 
awareness to concrete action, beyond ancer and damning critiques to institutional change (Cobble, Etta and Florika 1972; Fodor 1974b; Moutton 1972; Payne 1971).

Kreiger (1974) explains that even though women become aware of and talk about modify'ing socialized feelings, responses, actions and reactions through consciousness-raising, it is something eise to actually transform one's behavior. "The knowledge that a woman is socialized to be submissive, for example, does not by itself help her to overcome her servility. She might need to experience [through therapy] how she holds back the dynamic parts of herself, or to deal with her fears of being assertive" (p. 5). She describes her attempt to combine consciousness-raising and Gestalt in a weekly women's group which she led, and explains the dilemma involved for her in attempting this synthesis.

I have had to constantly question the effectiveness of what I am doing. How well is this fusion working? Does concentrating on therapy detract from the effectiveness of a consciousnessraising group? Does emphasizing therapy hinder the process of raising people's consciousness. After someone has worked on something important abcut her personal life, does talking about how her work related to women in general take away from the intensity of her experience? By not putting total energy into either method, am I cheating the women involved? By attempting to do both, am I, in effect, doing neither adequately or thoroughly enough? These are just some of the questions I've asked myself.

(pp. 1-2)

Tennov (1972; 1974; and Payne 1974), rejecting the professionalism of psychotherapy, developed a self-help counseling project $\left(C_{1} C_{2}\right)$ to be used in conjunction with consciousness-raising groups. The model is somewhat akin to the co-counseling model, for roles of interviewee $\left(C_{1}\right)$ and interviewer $\left(\mathrm{C}_{2}\right)$ are interchangeable (at times decided by the fiip of a coin), and the $c_{2}$ does not give advice, analyze or interpret but 
is an accepting attentive listener, an advocate for the $C_{1}$. As Tennov (1974:1) explains, "To taik about one's problems is not sick, and to listen to someone talk is not psychotherapy."

Another alternative developed by feminists are Wonen in Transition Houses, now in existence in several larger cities. Some function as a place for women in transition to stay, while others finction more as therapeutic communities for women (Raffini 1975; Soh 1974; "Women in Transition" 1972). The book Gettirig Clear: Body Work for Women (Rush 1973) is an important example of self-help for women. In it are ircluded interviews with 14 Bay Area therapists and collectives specializing in such diverse aspects of the growth movement as Gestait Therapy, Acult Play Therapy, Massage, Food Awareness, and Hoinen's Health, as we11 as numerous techniques and exercises (particularly focused on women and the reality of bcing female) "which are easily and safely used by anyone and can be useful tools in daily life" (p. 6).

Some articles began to appear in the popular and alternative press encouraging women to be selective about their choice of a therapist, explaining to women that a therapist's theoretical orientation and personal politics do influence therapy to a targe degree and that it is incumbent upon therapists to explain to prospective clients their values and orientations. These articles explain the therapeutic pretense of power and authority, attempt to demystify therapy, and encourage women to choose a therapist based on recommendations from feminists and their own experience during an initial consultation (Cleyeland Woman's Counseling n.d.; Rush 1973; Women in Transition KNOW). krákauer (1972:35) advised women: 
Don't assume or let a therapist tell you that your assessment of the interaction is less valid than hers or his. You're not deaing with the Divine Omniscience, just someone with a different opinion. Trust your judgment about what's best for you. . . . Question closely anything the cinerapist says that you don't think she or he would say to a man. If a therapist doesn't see more options for you than you do for yourself, maybe you should be her or his therapist. . . . Look for nondefensiveness and unpretentiousness. Ask whatever you want, and see how you feel about the answers. Firialiy, arm yourself with a healthy irrevererce and the understanding that, regardless of politics, a therapist who implies that you shculd be a certain way (whether that way is "normality" or that therapist's particular notion of acceptable "deviance") might make it harder to explore who you are.

In response to the argument that politics have no place in therapy, Krakauer concludes: "Understanding the connections betiveen objective conditions, the myths that support them, and personal experience is psychology. Sharing these understandings is therapolitic" (p. 34). In November 1972 , the first advertisenent appeared in Ms. for a referral service to feminist therapists, in New Yo:k City. 17

Feminists began to call for a new psychology of women, and in so doing to ariculate fantasies ard expectations of what $a$ therapist using the new psychology would believe and do. Some returned to the wark of such theorists as Aider, Horney, Jung, Klein and Thompson for new perspectives on women's psychology as developing from the social coritext (Brogen 1972; Rojas 1974; Walstedt 1971; Yurmark 1972). Brien and Sheldon (1975) discuss the applicability of Gestalt to work with women. Silveira (1972:15) says that a new psychoiogy of the oppressed and oppressor is needed as a basis for a new psychology of womer.

17 These scrvices have developed in several larger metropolitan areas, providing lists of feminist therapisis and encouraging a woman to "shop around" before she decides on sumeone. For a description of the one in Berkeley, see Appendix $F$. 
You have to rave, ard we badly rieed, a psychology of the oppressed and the oppressor. We need guidelines of mental health for a person whose environtent is totally opposed to her personal fulfillment because she is a member of a class. We need an analys is of the seli-destructive and the creative ways of dealing with this ervironment. For women in particular we need a psychology which understands the results of being trained from the day you are born to live intimateiy with your oppressor, to have no home away from him, and to seck your total personal fulfiliment through him.

Chesler (1972). on the other hand, argues that "political' insight about one's own cppression is no more a sure road to paradjse or eartin than is the achievement of 'personal' insight a guarantor of individual happiness" (p.124). Instead, she suggests a new female psychology dased on a shift in women's primary ego identity.

Woman's ego identity is rooted in a concern for 1 inited and specific "others," and for what pleases a feu men. Woman's ego identity must somehow shift and be moored tipon what is necessary for her own survival as a strong individual. . . . Any woman who successfully becomes interested in arid begins to achieve various powers directly, and not trrough or for a "man." or a "family," is, within the psychological kingdom of patriarchy, committing a radical act, i.e., ar act that risks "winning." (p. 256)

As early as 1971, many of the articles appearing in the magazine Radical Therapy began to talk about an integration of radical therapy and a feminist consciousness, in varying forms, most of which incorporated a radical critique of the political and ecoromic system with particular emphasis on the position of women in society (for example, Brown 1970; Parun 1971; Pines 1971). 18 since 1970, the radical psychiatry movement

18There are many similarities between the assumptions of radical therapy and feminist therapy, in particular parts of their societal critiques, their emphases on pover, and their concerns with the relationship between the personal and the political. However, since few feminist therapists in the interviews and few articles in the ijterature mentioned any relationship, it is not deait with here except in the ways it relates to women. In adition to the two radical therapy jotirnais, Radica? Therapy and Issues in Radical Therapy, both of which were read extensively as part of this esearch, see Agel (797), 1973), Anderson (1973) and Halleck (1971). 
in Berkeley has been incorporating a Transactional Analysis mode? in conjunction with a radical political perspective with a goal of demystifying people's oporession, teaching radical political values, and helping people learn to reclaim their power collectively. Nuch of their work has been in developing an extensive anaiysis of sex roles utilizing TA theory. Basically, they view men and women as scripted differently, with neither programmed to be whole human beings. Thus, women are programmed to develop their little professor (or adapted child), nurturing parent, critical parent, and not their adult or child. Their therapy is focused in part on compating these sex roles, both in themselves and in the people they work with. Much of their work is focused on enabling women to be potent, to get what they need without adapting or rescuing, to confront discounting, and to maintain contact with other women, utilizing a group approach ("The group situation is the most auspicious for women since it's obvious that there are no individual solutions for oppressed peop?e and to have strength we must band together" Wyckoff 1970:128). However, although they have developed strategies and techniques for dealing with the particular ofpression of women, they refer aiways to what they do as radical psychiatry and not feininist therapy (Hemes 1970-71; Steiner 1974; Thomas 1971; Vance 1971 a,b,c,d; Wyckoff 1970, 1971, 1972-73, 1973).

Out of the responses of the mental health field to feminism and this feminist search for alternatives, feminist therapy has come. 


\section{$X$. FEMINIST THERAPY}

In Aprit 7973 the first advertisement appeared in Ms. for feminist therapy. In the June 1975 issue, under the classified ad heading of Services, haif of the advertisemerits for therapists and therapy referral services listed such descriptions as "feminist therapist" or "feminist psychotherapy." A list pubiished by kNOW in the early seventies included 43 reminist therapists, and Jacobson (1973) risted seven feminist therapist collectives in various parts of the country. However, given this clear evidence that such a thing as feninist therapy exists (at least to the degree that there are women who label themseives as feirinist therapists and their work feminist therapy), there is a notable absence in the literature, particulariy the academic and professional joumals, of any discussion of what feminist therary is and even less on what feminist therapists would do. The articies located in the Titerature on feninist therapy per se number 21, of which two are papers written for courses in graduate school (Eoatmian 1973; Fashing 1974), seven are speeches presented ot conferences and conventions (Feminist Counseling Collective 1974: Lemen 1974; Munter 1975; and five speeches from a 1975 San Francisco Conference on Women and Mental Health, discussed together ai the end of this section), and the remainder of which with two exceptions are brief articles appearing in variolis alternative papers and magazines (in particuiar Padical Therany). All are largeiy theoretical: there are no studies of feminist therapy. i.erman (1974) and uacobson (1973) both stress that this abserice of any published "how-to" of teciniques or theoretical stances ard the 
lack of clear leadership makes even more inipressive the development of feminist therapy. Lerman explains that in talking with feminist therapists across the country, she finds a common philosophy and a common language.

What is happening is truly exr.ting in that it seems that therapists throughout the country are independently arriving at the same concepts and changing their mocies of interaction with clienis. It is truiy a grassroots occuricne witrout a "name" leader. It does feel as though there is a conmonality about what feminist therapy is and what happens in it.

(p. i)

Although Edwards, Cohen and Zarrow (1975) speak of "feminizing" techniques from other forms of therapy, most of the literature agrees that feminist therapy is less any set of techniques than it is a set of values or attitudes from which a therapist works. Jacobson explains, "It is more amorphous---an underiying idea, a driving force for change, an aticitude" (p. $c 1)$. Lerman concurs:

Techniques [in feminist therapy] are quite variabie and, in my view, re?atively urinpcrtant. What most clearly differentiates feninist therapy for me from other types of psychotherapy is a difference in philosophy.

(p. 1)

Several cefinitions are presented, mostly fairly vague and circular. For example, Walstedt $(1971: 10)$ defines a feminist psychotherapist simply as "somecne who supports and understands the desire for femle equality," while Silveira (1972:21) explains that feminist therapy is "courseling which affirms women's liberation and proceeds without power differentiais between counselor and counseled." In both definitions, however, feminist therapy's rocts in the women's movenent ard overi poitical position are clearly stated. In the available literature, there are certain cominon areas of consensus about what femirist therany is, and other areas where agreement is less clear. The areas of corisensus will 
be discussed first.

Two basic assumptions are repeated in all discussions of feminist therapy. The first assumption is that the client is competerit, worthwhile, of value as a person, and irinerently "OK." In tris stance, feminist therapy acknowledges the influence of the humanist movement, but this humarisn is modified by the second assumption. The second assumption is the idea that 2 woman's potential is molded and shaped by the society, in particular by sex-role stereotyfes. From these two assumptions follow two core concepts of feminist therapy, which aro repeatedly reiterated. The first has to do with the therapists attitude toward the client, the second with the therapist's attitude toward the client's problems. The distinctions overlap somewhat but nonetheless will be used in this discussion as much as possible.

First of a 11, because feminist therapy views the client as competent, it is concerned with how the therapist relates to the client. A goal is for the therapist to be a nonauthoritarian, nonhierarchical figure, potentially an equal with the client. As Cejanikus and Pollner (1974:10) expiain, "It has to do with the whole idea of new models of intimacy between equais." Eerman (1974:3) continues:

The [ferririst] therapist does not take the position of expert about her client. She. . viels the clicnt as.. . the person who is most knowledgeable abcut her owl fealings, thoughts ard needs. From this perspective, the theraoist coes not presume to tell the client about herself, diagnose the client or prescribe ireatment. Ary cominumt for psychotherady arises frum an irterchange in which the thrapist dnes rot assune that her opirions have any greater weight than inose of the ciient.

Rather than elwhasizing the therapist's expertise (and power) and thereby the clienc's dependency, the client's personal puwer is stressed and the therapist is expected to "open herself up to change" "Dejonikus and 
Poilner 1974:17) and attempts to mitigate any hierarchical authority she may possess. It is explained that this is critical becalise women have been trained to belicie (and experience in reality) that they have iittle power to cetermine their ov'r: values, needs. actions ard thoughts and have given away the power to do so to othors. A goal of feminist. therapy therefore is to enable a wolan to re-gain control (power) over her life, to take responsibility for herself. Thus, Leman (1974:4) explains that feminist therapy attempts "to help the woman client validate her ow exveriences rather than to undercut this process through the use of the authority position which the therapist can so easily assume." Because of this focus on the therapist as a real person, transference is seen as irreievart. Because the client is seen as competent and krowledgabie of her own wishes, resistance is similarly dismissed.

Several authors in the last year draw the analogy between women (or feminist therapy) and healing (Mander and Rush 1974; Valliant 1974). Mariechild and Williams (1974) describe a feminist therapist as a therapist who functions as a midwife, helping women hea themselves by guiding them into the unconscious and through the labor of becoming avare of their own positive abilities and delivering themselves of their fears. "We are midwives involved in the process of helping women give birth to themseives" (p. 6).

Several behaviors follow from this position. First, encouraging a vornan to shop for a therapist is nientioned (Lernan 1974; Perlstein 1975). Again, this cones from the idea that therapy is a service the therapist offers the client, and therefore that the cliont is the one 
to determine, utilizing her judgnent and impressions, the degree to which a particular therapist neets her needs. Secondly, the feminist therapist shares herself, showing that she is not only strong but vulnerable, that she is not godlike and does not have ail the answers-thus demystifying "the image of the mind-heâler" Jacobson 1973:C5; Feminist Counseling Collective 1974). Thus, a feminist therapist's life is integrally corrected with her therapy. "To talk aboid feminist therapy you're taiking about someone who's living a lifestyle--it's not just a therapeutic philosophy" (Munter 1975). As a woman and as a feminist, a feminist therapist shares her experiences of being a woman in this society, and a bond of commonality develops between client and therapist. As the therapist shares who she is, she serves as a strong role model for her clients of a self-actualized womar who has discarded traditional images of what it means to be a woman and moved in the direction of new norms and iffestyles (Shinkas 1974). The third behavior has to do with values. Feminist therapy is acknowiedged from the beginning to be a value fosition, and several articles stress that a part of feminist therapy is making one's values overt (perhaps in the first session), again to demystify the therapist and the therapy process. As Dejanikus and Poliner (1074:10) expiain:

Most therapists dor' ' $t$ mike their vaiues overt to their cijents. They mystify their clienis. They won't tell them how thej' feel about sexuality; they 'yon't tell them about their own present. unresolved conflicts. . . Pasically, we think that's a lot of crap. Therapy alnost diways risks bejng a process where the therapist lays values on the client. The only way out of that problem is to make the therapist's values so overt that the client has sone power to accept them or reject then. Getting rid of that secret misstique is one part of feminist psycho.therapy. 
As a further means of demystification, Fashing (1974) stresses the importance of having a theory of therapy that is ceachabie to clients so they will come to rely less and less on the therarist. Lastly, several writers mention utilizing a rontract-based or problem-solving approach to the therapy to further incorporate the mutuality they fee is so critical and emphasizing experiencing rather than just taiking about new ways of being.

The second core concept of feminist therapy has to do with how it views a client's problems. In essence, feminist therapy accepts the Feminist Critique described earlier in this chapter and, believing that much of a woman's emotional trauna comes from societa? pressures, sees a woman's probiens in a social context. Feminist therapy rejects the whole concept of "sickness," believing that there exists soine distress in a woman's personality for which she is not responsible, but rather has acquired simply by being a woman in a sexist society (Lindsay 1974; Fashing 1974). Thus, part of feminist therapy becomes helping clients to explore those aspects of their social conditioning which have added to their personal problems and to separate those aspects for which they must take resporisibility. "The goal of a feminist theory of counseling would be to raise the consciousness of all people and to liberate people from roles that have literally made then sick" (Fashing 1974:9). However, whereas consciousmess-raising works to destroy the myth of individua? responsibility, feminist therapy focuses on how an individuat responds to the world, on what she wants, how she stops herself from getting it and how she is stopped from getting it.. on the interplay between the individual and society. Leman (7974:4-5) 
explains:

[An] important philosophical position which plays a large part in feminist therapy is the tenet of the feminist movement. that "the personal is politica?." We heip the woman client to differentiate between what she has been taught and has accepted as socially appropriate and what may actualiy be appropriate for her. . . Where the more ustal therapy encourages cilents to introspect and thereby learn to know theinseives better, feminist therapy helps its clients look outward as weil as inward and differentiate ciear? $y$ what belorgs to the society and is being imposed and what is interral.

Helping a woman separate the interna? and the external, in addition to enhancing her self-confidence and sense of personal power, heips hev learn that she is not crazy, that what she has been perceiving all along is that real double bind which exists for women. As a corollary, feminist therapy also endeavors to break down sex role sterectypes and help women develop as they wish without the constrictions of sociecaily determined standards of appropriateness, to increase a woman's awareness of her options and her power to make choices for herself. For example, whereas women are taught to nurture others, feminist therapy gives her permission to nurture herse? i (Lerman i974). Self-assertion is also a focus.

At times, this newfound corsciousness may lead to rage, anxiety or guilt, and feminist therapy is concerned not to discount or invalidate the reality base of these feelings, by labeling them irrational or out of proportion. Litimately, the feminist therarist wants to help a woman channel her rage and to make clear choices, but only if channeling does not mean repressing, diluting, or derying. There is an awareness, however, that therapy has limits, particulariy in changing economic conditions. As Lerman (1974:10) explains, "Al7 human pain is not directly accessitile to psychological intervention. We cannot change the 
world in our of ices." Rather, the role of the feminist irerapist is "to relp a woman recognize the scurces of her uppression and what power she actually does have to affect her situction" (Dejanikus and Pollner 1974:11). Often, this mearis that a feminist therapist acts as a referral source, telling clients of other woman andor organizations who are struggling with similar issues. Some discuss the importance of fee negctiation in tinis context. The pariel members at a recent. conference in Boston agreed that "any woman who calls herseif a feminist therapist and doesn't charge on a siding scale within her clients' means is not a feminist therapist" (Edwards, Cohen and Zarrow 1975). Mander and Rush (197f) present a somewhat different perspective on feminist therapy and therefore it is presented apart from the others. They defirie therapy as healing, and explain that cecause feminism enables a waman to become integrated, to trust other women, and to be conscious of the social context and of the connections between her life and the outside world, between sex and society, work and play, body and mind, it is therapeutic. 19 Feminism, then, is therapy.-."We don't necessarily need 'therapists' to do 'therapy'" (p. 51).

Urearthing the true natures of ourselves as women today is healing in itself because we can then understand and function congruentiy with our energies. Seeking to correct the imbalance of women's position in society and in their persons? iives is also a healing process which helps everyone get more in toluch with thernselves.

Although they speak of wishing to move beyond techniques, the ir book contains the only listing of identified feminist therapy "techriques"

19A speaker cited in Edwards, Cohen and Zarrow (1975) disagreed, saying that feminisn is not therapy by itself and that no matter what-or how perfect-- the social and econonic siructure, there will diways be difficulties in hunan interaction. 
or exercises in the literature. They explain that before incorporating any technique, they ask themse?ves:

Is this based on concepts of segmentation or irtegration? Where did the philosophy behind it cone from? What political stance does it take and advocate? What relationship to power does it encourage? Does it bear the stamp of a class value? Does it integratie body and mind? Is it a process which will leave room for opening and balancing of cur female energies? Does it emphasize the technique or the content? (p. 96)

Overal?, they differ from the other literature describing feminist therapy in their emphasis on the spiritual and on the healing or therapeutic aspects of feminism itself and accordingly, on thair deemphasis of therapeutic skills and the tinerapeutic process.

In the literature on feminist therapy, a number of issues are raised on which there is no clear agreement. They include whether feminist therapy is really any different than other therapies, whether faninist therapists should be women, wether feminis: therapists car (or should) work with men, whether the objective of faminist therapy is to make wonen into feminists and following that, whether therapy is merely a personal solution.

In response to the first issue, many feel that the most important thing is that the therapist be a sensitive, compotent human being--in other words, a good therapist. However, others explain that a ferninist therapist must have a clear political consciousness, a broader understanding of sexuality, the ability to share herself, and an awareness of alternatives. For some, the differences seem to be a question of the quality of one's conviction; others stress the presence (or absence) of certain beliefs. Dejanikus and Pollner (1974:11) state: 
You ask what's a feminist thempist. . To know we'd. . ask certain questions: will she try to keep somebchy in a bad marriage? Will she push monogamy? Will she talk about peris envy or in any way inculcate those kind of fucked-up Freudian ideas? Cbviousty, she can't do any of those things and be a feminist therapist. There's an enormous darger when a therapist has no feminist consciousness, no political consciousness.

In response to the question about whether feminist therapists mist be women, most women fee? that because of the potential comilonality of experience existing between women, the inherent institutionalized power a man has in relation to a woman, and the advantage of a strong female role model for women, feminist therapists who are women have more to offer women cijents at this time. Some, however, explain that there is an important place for male therapists who are serious about feminisn in working with men. 20

Most feminist therapists writing or interviewed in the ?iterature seem to see few men, but do feel a feminist therapist cän work with men, explaining that the goal of helping a person becoine himself or herself and assume personal power without the restriction of traditional sex-role stereotypes is a need of men as well as women, although men arn enculturated differently and therefore bring different issues to therapy, in particular not being able to get in touch with feelings and an overdependence on rationality.

In response to the issue of whether the goal of feminist therapy is to make women into feminists, Lerman (1974:10) resporis that she both agrees and disagrees. She does want her clients to become feninists

20The Lesbian Feminist Therapy Research project (cited in Edwards et a?. 1975) refers to their statistics which show, for exanple, thrit wonen who had been in theray came out to their fanilies with much less frequency than those who nad not, to argue that even a feminist therapist. may not be appropriate for a lesbian if she is not also a lesbian. 
if "feminist" means awareness of external cppression and the attempt for a woman to gain self-definition as a person and persona? power to the degree possible given that existing external oppression. However, if becoming a feminist means a woman wouid have to accept totaily ail tenets of feminism, then that would not be her ycal.

Women come to therapy with ali degrees and types of comirit. ments already established: to specific people, faniiies, ideologies, jobs, life styles, and values. The goal is to help them become the best person they can be, within the limits of their persona i circumstances and the potterns of society in general. If that means they reed to becone active feminists, fine; if not, fine too.

Webbink (1973) explains that feminist "shouids" can be as destructive to women as the traditional "sholids," and that her goal is to free a person from all "shoulds" so she can choose ror herself, which she considers rea liberation. Fashing (1974) seems to fee?, however, that: individ:rals when liberated through ferninist therapy will want to change oppressive institutions and that is a goal for her.

In regard to the last issue, some radical feminists criticize feminist therapy, saying that it is cotnter-hevolutinnary because it leads women away from the political into the personal and defuses anger (Jacobson 1973). Most feminist therapists disagree. Some explain that some degree of personal actualization is necessary before anyone can be effective in any movement. Sirveira (1972:22-23) feels that using the persona? solution/political solution dichotony to attack psychology is spurious. She explains that psychology's present emphasis on the personal solution "is a resuit of the institution's ma?e, white, status. quo reactionary bias. . . Psychology properly defined is the study of intra-organisn laws that limit and structure human behavior." 
In January 1975, a Conference on Women's Mental Health was held in San Francisco, and in Aprit 1975 a similar one was held in Beston. Papers presented highlight and refocus what seem to be additional issues in feminist therapy currently (Dutitzky 1975; Duxbury and Hearoy 1975; Edwards, Coher! and Zarrow 1975; Hunter 1975; Ferlstein 1975; Wolman 3975). The developers of the Boston conference (Edwards, Cohen and Zarrow 1975:18) explain that they organized the conference out of their dissatisfaction with the published material available on feminist therapy and their desire to answer questions about now to integrate feminism into the therapeutic process.

[We] wanted to know what other women think feminist therapy is--a philosophy, a practical theory, a definable skili? . . . Where does therapy stop and consciousness-raising begin? While there is no such thing as value-free therapy, and we believe in the value of feminism for women, at what point is a client making her own choices instead of merely reacting to her socia? condition-or her therapist's politics? Feminist therapists also have to decide which skills and theory from other schools of psychology are useful to us and which to throw out.

Some issues raised, such as structural questions of fees, times, availability, dealing with value orientations of therapist and client, men as clients of feminist therapists and as feminist therapists themselves, and straight women working with gay women, were incorporated into the interview used in this study. However, the most centra? issues debated at this conference had to do with how professionalism and fees related to feminist therapy and how therapy related (or doesn't reiate) to the saciety (or the system) (Perry 1975).

Dubitzky argues very strongly that it is impossibie to have a therapist-clierit relationshis that even approaches any equality of power, which is a criticai ispect of feminist therapy, when the therapist 
is committed to the responsibilities and rewards of professionalism: particularly when that professionalism is composed of learning from riaie institutions. Following from this, Duxbury and Heaney, and Wolman, question the degree to which therapy, working on an individual ievel with individual problems, can even be reievant to the need to change the current sexist capitalist society. They are cuncerned that it is too easy for therapy--inciuding feminist therapy--to become ariother "external addiction" of the privileged few. Duxbury and Heaney (1973:3-4) state:

The harsh reality of economic survival ta'es precedence over head-tripping. A white middle class therarist must recognize her limitations in dealing effectivel; with those women who are struggling every day for economic surviva?. . . How relevant can Gestait exercises in awareiess be when the women cannot buy tampax or toilet paper with hor rooristamps? . . A therapist who charges $\$ 10$ or more an hour to a typist who makes $\$ 2.50$ an hour canrot consider herseif a feminist.

It is not enough, they argue, for a feminist therapist to be a feminist-she must also be working for raciical persoral and political change. Feminist therapy must assume a role of helping women become aware of internalized oppression and ways to reverse complicity with one's institutionalized powerlessness. Thus, Duxbury and Heaney (1975:1) state:

We believe feminist therapy can be a valuable tool in heiping women to reclaim some of their power and become aware of sore internalized blocks towards expression of that power. Eut those blocks were not created in a vacuum and to only work them out in a therapist's office is just another vacuum. Allowing a wuman space to express her anger in a group of other women may be a positive first step but without that anger being allowed arid encouraged to tale place outside in the worid where it belongs, her power is snort-circuited. We feel that if a woman is to consider herse!f a feminist therapist, part of the process of therapy must include making ciear the political connections between a voman's personal life experiencos and her socially reinforced sense of poweriessness. Finding solery inciudua 
solutions to persona? problems is a symptomatic approach. We can no longer afford to supply band-aids to our wounds: We must look and see what is causing all this bleeding.

Similarly, a speaker at the Boston conference defines feminist therapy as helping "women transform their unconscious, covert slave rebeilion to conscious, open varfare against the persons and institutions which work to enslave them" (Edwards, Cohen and Zarrow 1975:18).

In this literature on feminist therapy, several interviews with individual feminist therapists exist. Jacubson (1973) interviewed itive feminist therapists, as did Boatman (1973) but both are brief syntreses of interviews with feminist therapists selected arbitrariiy. To date, in none of the available literature has there been any attempt to systematically determine what feminist therapy is (and isn't), and to describe its thecretical bases and cite examples of its practice, based on information provided by those actualiy doing it. That is the goa? of this study. 


\section{CHAPTER III}

\section{RESEARCH DESIGN}

\section{INTRODUCTION}

The basic design atilized in this study is a qualitative methodology. Finstead $(1970)$ and Glaser and Strauss (1370) argue that such reseirch is not merely exploratory in function or prefatory to quantitative research but is a distinct research strategy particulariy applicabie to the construction of sutstantive theory. "In short, qualitative methociology advocates an approach to examining the empirical social world which requires the researcher to interpret the real world fromi the perspective of the subjects of his investigation" (Filstead 1970:6-7). Because it is based in the tradition of versteren, or understanding, qualitative methodoiogy assumes that knowledge (and hence, understanding) of any social phenomenon-such as feminist therapy--can only de attained by an approach which incorporates what Filstead (1970:4) calls "both an inner and an outer perspective." In this study, that was done by focusing on the feminist therapiscs" perspectives of feminist therapy, her own and that of others, coth on

a theoretical and on a clinical level. In turn, this methodology provided an approach in which the begining formulation of substantive concepts preceded the development of formal thcories, rather than vice versa, as Glaser and Strauss (1970:304) explain: 
Ignoring the task of discovering substantive thenry that is relevant to a given substantive area is the result, in most cases, of believing that formal theories car be directiy applied to an area, and that these forma? theories supply all the necessary concepts and rypotreses. The consequence is often a forcing of data and negiecting of the relevant concents and hypotheses that may energe. Aljowing substantive concepts and hypotheses to emerge first on their own enables the anaiyst. to ascertain which of diverse formal theories may be inclusive of his substantive theories, thus enabling nim to be more faithful and less forcing of his data (or more objective and less theoretically biased).

In this study, an extensive literature review was itself the initial form of the field research, out of which tentative hypotheses about the theory and practice of feminist therapy began to emerge. This continual intermesning of data collection and analysis with no clear-cut line between the two is cited by Glaser and Strauss as characteristic of this methodology, leading to the perusal of mutiple hypotheses concurrently. Thus, hypotheses from the literature review became the questions raised in the interview; and in the interyiew process the second round of data collection and analys is commenced. The actual thematic analysis of the interviews themseives was the third round of the methodology, out of which came the summary and conclusions, the ordering of the findings into a discussion of some of the parameters and tenets of feminist therapy.

The specific design of the research was as follows: A sample frame of those who identified themselves as feminist therapists or counselors in thres of the four major metropolitian areas on the biest Coast--Portiand, Seattle, and the Bay Area--was first gererated and then surveyed via a questionnaire for characterizing data, with particular attention to differences among the three locations surveyed and among the varying degree levels represented. The prinuly information for 
analysis was then collected by administering focused interviews to a random sample of those feminist therapists. The interviews were taperecorded and trariscribed, and the contents thematicaliy analyzed to delineate issues, identify areas of consensus ard areas of difference, and characterize clusterings of response and assumpive patterns withir the population.

Initially, the interviews were planned to be purfosive. However, a desire for increased generalizability led to the wilization of a more formalized process for locating potential members of the somple frame, development of a questionnaire to identify those aciually in the sample frame, and application of a random number table to the sample frame to choose those to be interviewed.

The population was purposefuily chosen to inciude residents of timree metropolitan areas instead of just cne because as a newiy emerging form of therapy, it was felt that feminist therapy would perhaps be practiced, defined, or adhered to differently in different areas deperding on their degree of exposure to it and their receptivity to therapeutic and cultural innovations in gerierai. For example, in particular, it was felt that the Bay Area was an environment where there was a heightened awareness and an accelerated adaptation of cultural changes in general and an historical fostering of radical and feminist movements. Thus, no one area could give a complete picture of feminist therapy as it is currently being practiced on the west Coast. In the questionnaire analysis, attention is giver to comparison of responses among the three areas to determine if in fact differences presuned to exist among them are reflected in the characteristics of 
the population.

The criteria for inclusion in the population were that the person live within the chosen metropolitan areas, that the person be invoived in therapy in a role other than or in addition to a student or residency capacity, ard that the person identify themselves as a feminist therapist. Self-identification was decided upcr as a means of discriminating feminist therapists from non-feminist therapists because a revicu of the literature indicated no cleâr definition of feminist therapy against which an otherwise-identified feminist therapist could be compared. This criteria for self-identification led to a certain amount of questioning among respondents. When asked to reply "yes" or "no" to the question, "Do you consider yourseif to be a feminist therapist or counselor?" they could in turn respond that it depended on one's definition of a feminist. therapist or courselor. It colid be argued that many who excluded themselves on the basis of their "no" or "don ' $t$ know" response to this question would, if surveyed, be no different than those who replied "yes." However, a basic assumption was that the decision to forma?ly identify oneself as a feminist therapist was a crucial aspect of being a femirist therapist ${ }^{\text {and }}$ therefore that those who had made this identification for themselves, for whatever reascrs, were iikely to

IRecentry, a woman who identified herself as a feminist therapist on the questionaire reported in another context, "I becanc a feminist therapist the day Susan Thomas asked me on her questionnaire if I was one." Feninist therapists interviemed themselves discuss and disagree on whether self-identification is a recessary criteria for feminist therapy (see Chapter IV, Section III, Qualifications About Feminist Therapy). 
differ (although perhaps in very intangible ways) from those who had not.

The initial research divermal was iocating the sample frame. Contacts with what seerned to be cbvious sources (such as the Nationa? Organization of Women) reveaied no single organization in any one of the three areas with any potentially complete list of feminist therapists in their area. Therefore, the decision was made to utilize the "natural helping retwork" or "natural system of service delivery," described by Collins (1973:46) as "a retwork of relationships in which individuals seeking a specific service find it, without professional interverition." It was assumed that such a network exists within the femirist movement, an unformalized yet highly efficient system for referral, evaluations and listings of individuals and services adapted to, sympathetic to, or needed by women invoived in and peripheral to the womer's movement, including legal services, child care, gynecologists, rap groups, as well as therapists identifying themselves as femirist therapists or sympathetic to the feminist movement. A further assumption was that a systematic process of tapping into and moving through the network would ultimately result in the generation of a sample frame encoripassing as much of the population of feminist therapists as it was possible to locate. This assumption is substantiated by the work of Milgran (1967; Travers and Milgram 1969) on the "small worid problem" in which it was found that highly efficient linkages did exist between even randomiy chosen individuals. Since in this study, individuals and organizations were not randomly chosen but were located in the same area and were involved in some way either with therapy or with women, it seems very 
likely that feminist therapists wou?d be known to feminist or wornen's organizations and/or to each other, producing, when contacted, the most complete and representative sample frame possible. Eritry into the network involved two phases. The first phase was an attempt to repiicate the process a woman seeking reminist therapy wouid go through in iocating a feminist therapist. The second phase was asking all potential feminist therapists located to list the names and addresses of other feminist therapists they knew (the technique of snowballing). Because of time limitations, the second phase could not be foilowed through to completion. In addition, the actual size of the population is not constant because of the transcience of its members, among other things. However, at the point in time at which the research was undertaken, 65 percent of the known population had been contacted, and it is assumed that the sample frame so generated is representative of the population of feminist therapists in Portland, Seattle, and the Bay Area.

Finally, two aspects of the research design deserve some discussion, the utilization of interviewing as a means of data collection and the question of researcher bias. Becker and Geer (1970) argue that interviewing has a basic shortcomirg as a research technigue when it is used as a source of inforiation about events that have occlirred elsewhere and are merely described by informants. In this study, then, there is the possibility of discrepancy between feminist therapists' descriptions of their proctice and their practice itseif, and between their theoreticai orientations as they present them, perhaps influenced by how they think a feminist therapist "should" respond, and their actual beliefs. Deutscher (1970) raises the similar issue of 
distinguishing between reliability and validity, argating that although research data may be reliable (i.e., the interviewe says what she thinks), such reilability is not equatable with validity (i.e., that she does what she says she does). These are obvious limitations of such an exploratory study.

As a strategy, qualitative methodology demands that the researcher be on the inside of what is observed, for it is only through participation in an activity that interest, purpose, point of view, value, and meaning can be generated. Such participation, however, aiso creates bias, for the observer becomes part of the observed and in turn has o personal stake in what is studied (Filstead i970). This issue of research bias is dealt with in Section $V$ of this chapter.

\section{DEVELOPING THE SAMPLE. FRAME AND CHOOSING THE SAMPLE}

A fairly similar process of sample frame development was followed in all three areas. In the fail of 1974, initial contacts were made with wonen's heaith clinics, National Organization of Women, women's bookstores and resource centers, Women's Studies Departments, and YWCAs in each metropolitan area. Fublished directories of area-wide resources for women were used when available, as weil as posters iisting workshops, advertisements in the alternative press, and information provided by friends living in each area. When contacted, these sources in turn suggested other organizations and persons to contact, until at a certain point no new contact sources surfaced, and old ones were repeatedly mentioned. In this manner, 147 names were gatliered for the initial questionnaire mailing. 
Differences between the three cities were observed during this process. In Portland, the smailest of the three metropolitan areas, information was the least widely known and referral the least specialized and centered. Three initial contacts Women's Rescurce Center, Wonen's Heaith CIinic, and PSU Women's Stuaies) provided the majority of the initial names. These three places each had small lists of therapists to whom they referred (not necessariiy feminist) ard did not know of other more complete lists.

In Seattle, initiai teiephone contacts wich such organizations as N.C.W. and Women's Studies led to other organizations and ciinics. Four of those--University YWCA, Women's Resource Center, Seattle Center for Sexual Minorities, and Aradia Clinic--had compiled fairiy extensive lists of feminist therapists in Seattle, and these names were the basis of the initial seattle mailing.

In the Bay Area, the process was complicated by distance and sheer size of the population. Population size anc a certain "cultural heightenirg" seened accompanied by a higher level of specialization and organization. In the summer of 1974 , a locai alternative newspaper, the Bay Guardian, published a resource guide for women which inciuded a colnseling and mental health section. From the listings in this directory, contact was mato with the ionen's Switchboard, and the San Francisco and Berkeley Women's Centers. The former two were a source of the majority of the Bay Area naries. The Berkeley Women's Center appears to be the most organized referral source in the three areas. The collective irvolved with referral discussed my request for a list of names and decided that to give out the names of therapists on file with them 
"woulu be an whrar thing to do un?ess we were to cali each woman up first and ask if it were ox to give owit her name, and there just isn't time for us to co that."2 The Resolirce Directory aiso listed names of collectives and centers doing feminist and radical therapy. Other sources contacted ir, the Bay Area, such as bcokstores, generally suggested the timee initial sources previously contacted. In the Bay Area, it seems referral has become a discrete and specialized process. In order to ascertain whether or not a person fit the criteria for inclusion in the sample, a questionnaire and explanatory letter were developed (see Appendix $A$ and $B$ ). The letter expleined the goa? of the study, the purpose of the questionnaire, the overali research design and the criteria for inclusion in the sample frame. A notation was made on the bottom of the letter indicating to the recipient from whom their name had been obtained. The first question was designed to provide the information on which to base inclusion in or exciusion from the sample frame, asking, "Do you consider yourself to be a feininist therapist or counselor?" and adding, parenthetically, "I have not defined this further, wanting your answer to reflect your own personal standards and criterià." A "yes" or "no" forced-choice followed. The remainder of the questionnaire dealt with theoretical orientation, length of time having done therapy, degree level and field of degree, focus of practice, mode of practice, practice setting and areas of

RAfter meeting with them while conducting the interviews several months later, they were very helpfil and allowed a comparison of their list of names ith the ones obtained by the researcher. This is discussed further later in this section. 
specialization. Two final questions asked if a person vere withing to be interviewed and for the names and addresses of other feminist. therapists they knew of who could be contacted for the study.

The initial questionnaire (along with the explanatory letter and a stamped, self-addressed enveiope) was mailed on Deceniter 5, 1974 to those 147 therapists whose names were located as possible feminist therapists or places where feminist therapists might be practicing. Al though some replies were received by return mail, othars were returned nuch more slowly. Naries listed as other contacts on the returned questionnaires (if they had not already been sent a questionnaire, as was often the case) were sent a questionmaire packet as sonn as they were received. Since it was possibie for this process to happen several times (i.e., zin initial contact wourd list severa? names, those names when contected would Tish other nenes, etc.), iocating the sample frame by this means was a lengthy process. Approximately three weeks after the first mailing, those who had received the first round of questionnaires and had not returned then were contacted by telephone wher possible or by mail. Henceforth, à follow-up contact was made wheneyer three weeks her passed and a questionnaire had not been returned.

By January 15, 1975, 187 questionaires had been mailed out, with 40 of those 187 names generated from returned questionaires. After January 15, no new questionaires were sent out aithough questionnaires were still being returned, often with istings of additional names to contact. Table I indicates by area the 
questionnaires sent and the additional names generated, resulting in a potential population of $273 .^{3}$

\section{TABLE I}

\section{GENERATION OF POTENTIAL SAMPLE FPAME}

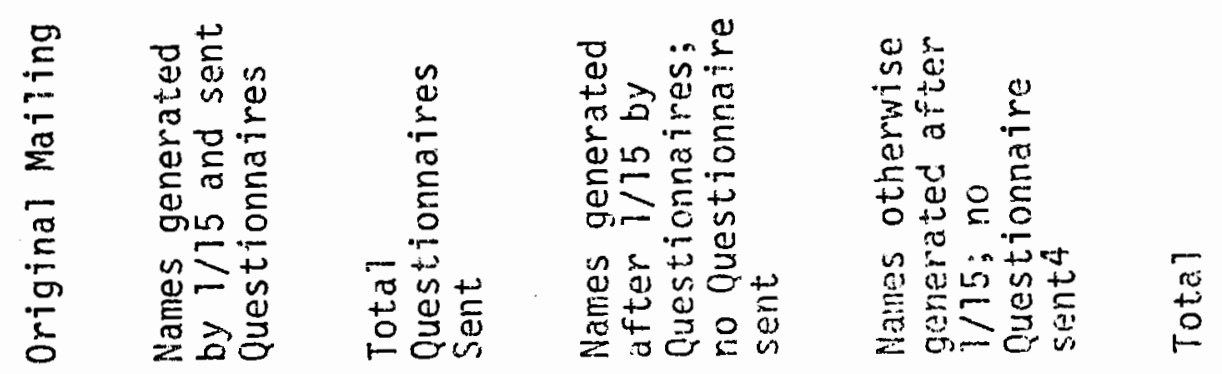

$\begin{array}{lrrrrrr}\text { Portiand } & 22 & 15 & 37 & 6 & 3 & 46 \\ \text { Seattie } & 50 & 6 & 56 & 22 & - & 78 \\ \text { Bay Area } & 75 & 19 & 94 & 26 & 29 & 149 \\ \text { Totals } & 147 & 40 & 187 & 54 & 32 & 273\end{array}$

It is interesting to compare the generation process in each of the three locations. The number of names generated by the questionnaire was proportionateiy much greater in Portland than in either of the other

${ }^{3}$ Interestingly, of these 273 riames, only four were male, and only one of the four said he was a feminist therapist.

${ }^{4}$ These names were obtained during the irterviews themselves (2), by the interviewer from bulletin boards and friends while traveing to conduct interviews (10), and from the Berkeley homen's Therapy Collective who granted the interviewer permission to compare the ir ist of names with the researcher's iist. of the 35 names they had on file, 15 were already known and 20 were new. 
two areas, alriost doubling the original rumber of contacts. It appears that in fortland, information about who the feminist therapists are is known primarily by the feminist thempists themseives. Of the 22 additional naines generated in Seattle after January 15, 18 of these were unnamed members of either a ferninist therapy training group or a newly forming women's courseling collective; and it is unclear how many would if contacted be fourd to be duplications of names previously obtained. However, even if this aspect of the Seatt]e response is not considered, some pattern seems observable just in the sense that in Portland (and possibly in Seattle), the numbers of additional names obtained iessened as the process progressed while in the Bay Area, the new names received or otherwise lucated kept increasing. This could be an indication of size above all else: obtaining a finite list of feminist therapists in Portiand utijizing the raturai heiping network seems possible in a finite amount of time. In the Bay Area, although a certain number of names were consistently duplicated, rames listed were equally likely to be nien names not previousiy contacted. However, it would be expected that if there had been no need to stop the snowballing process because of time constraints, duplications would ultimately have begun tc oucnumber new names.

After January 15, 1975, renewed efforts were nade to obtain those questionnaires which had not yet been returned. Twelve questionnaires sent in the totâ? mailing (of 187) were considered inapplicable because of unforeseen inaccuracies in the process of screening the mailing (i.e., one address sent three questionnaires repiled they were a woner's center but not a feminist therapy group; one women said in response to a 
reminder letter she had never received the questionnaire and was not a feminist therapist anyway, etc.). Thus, the actual mailing to potential therapists was 175 , hereafter referred to as the adjusted mailing.

of the 175 questionnaires in the adjusted mailing, 135 were returned. These questionnaires were divided on the basis of the response to the first question in which respondents were asked whether they did or did not consider thenselves feminist theranists. A number of those who responded qualified their responses by defining feminist therapy and by that defirition thereby including or excluding themselves, or saying that they didn't know what feminist therapy was and therefore could not respond. Criteria were estabiished for categorizing their answers and thus determining inclusion in the sample frame, but this process would have perhaps been nore accurate if in addition to the "yes-no" choice, categories of "don't know" andior "non-sexist" had been included. 5

Comments from those indicating a qualified "yes" (it must be noted that only a smail percentage of the "yes" respondents--i? of 105-responded in this way; most did not qualify their affirmation)-inc?uded coments qualifying their behavior ("but dori't always behave as such" or,

${ }^{5}$ Dubois (1975) in a similar study currently in process at Harvard provided a continuun of six choices, inc?uding: "I am a radical feminist therapist," "I am a feminist therapist," "I am a feminist and a therapist," "I am especialiy concerned with women's issues in therapy," "My concern with women's issues does not change the way I aciualiy approach therapy," and "Feminism is a political/social position, not. really a part of therapy." However, her study had not begun when this questionnaire was developed. 
"on a good day"), the meaning or narrowness of the term "feminist therapy," or the definition or implications of the term "therapy." One woman adding a question mark to her "yes" said, "Feninist 'yes'-. therapist "yes'," and another checking "yes" commerited, "but rumanist or "non-sex-role stereotype'" might be closer. For purposes of categorization, however, if a person checked the "yes" category, sine was included here and therefore in the sample frame, irregardless of how qualified her "yes" response.

Others did not check either "yes" or "ro" or checked both, sometimes adding a question mark between the two or ading and checking a "maybe" or "don't know" categorv. Their explanations inciuded:

I don't know. I haven't decided what "feminist therapy" means. I know I am a therapist, and I know I am a reminist. Does that help?

Yes in the sense that I am very aware of sexisin and patterns in our culture which have kept women back and get in the way of their becoming fully human. No in the sense that mer are completely equal in my groups--the aim is to recover our humanity. I guess it depends on how you define feminism.

For categorizing, any response which on the first question checked both categories or neither category, as well as those making their own categories of "don't know" and "maybe," was scored as "don't know." Some of those checking "no" expiained their decision. A majority of those comments objected to the "anti-humanism" and politicization of a ferrinist therapy position:

6The two exceptions are one woman in the Bay Area, a member of an explicitly feninist therapy collective, who checked neither and was nonetheless counted as a "yos;" and one wornan who checked "no" but added a big question mark and a qualifying comnent about ner uncertainty, who was scored as "don' $t$ know." 
Feminist therapy imp?ies "one" is politica? first--a therapist sacond. I see myself as having priniary allegiance to my patients--and so their ethical/moral/political connections.

I am a ferinist and a therapist. I feel this definition leaves me a lot more space than your term "feminist therapy." I work with both men and women, and the goal is to bring people to themselves. When feminist attitudes help this process, good--but I don't rake a tig deal of it.

One woman said that aithough she did some feminist counseiting, she did not do it with all clients, and therefore resporided negatively. Another wrote that she was a feminist in her own life but that was not the context of her work. One woman differentiated between utilizing feminism therapeutically, which she did, and being a feminist therapist.

I an not a therapist. I feel non-therapists are crucial. . in ironing out the contradictions between therapy (maiedeveloped) and feminism. [The particular focus or area of specialization in my work] is clarifying women's roies, options, conditioning--rectifying therapy-induced misconceptions.

Table II illustrates responses to the first question.

TABLE II

RESPONSES TO, "DO YOU CONSIDER YOURSELF TO BE A FEMINIST THERAPIST OR COUNSELOR?" BY PERCENTAGES

\begin{tabular}{|c|c|c|c|c|c|c|c|}
\hline & $\begin{array}{l}\text { Number of } \\
\text { Questionnaires } \\
\text { Returned }\end{array}$ & Yes & $\begin{array}{l}\text { Percent } \\
\text { of } \\
\text { Returned }\end{array}$ & No & $\begin{array}{l}\text { Percent } \\
\text { of } \\
\text { Returned }\end{array}$ & $\begin{array}{l}\text { Don't } \\
\text { Know! }\end{array}$ & $\begin{array}{l}\text { Percent } \\
\text { of } \\
\text { Returned }\end{array}$ \\
\hline Portland & 36 & 25 & $69 \%$ & 8 & $22 \%$ & 3 & $8 \%$ \\
\hline Seattle & 40 & 30 & $75 \%$ & 6 & $15 \%$ & 4 & $10 \%$ \\
\hline Bay Area & 58 & 50 & $\varepsilon 6 \%$ & 7 & $10 \%$ & 1 & $2 \%$ \\
\hline Totals & 135 & 105 & $78 \%$ & 21 & $10 \%$ & 8 & $6 \%$ \\
\hline
\end{tabular}


What seens nost important about this data is its validation of the natural network focus used in this study for locating feminist therapists: 78 percent of those returning questionnaires were in fact feminist therapists (and had the criteria for identification been different or ciearer, this figure may have been even higher). The degree of "accuracy" with which a person thought to be or referred to as a feminist therapist would in fact identify herself as such increased from Portiand to seattle to the Bay Ared, where only 12 percent of those contacted were not included in the sample frame. Again, this may reflect the greater specialization and/or specification of referral in the Bay Area. However, as indicated by the 2 percent level of "den't know" in the Bay Area as compared to 8 percent and 10 percent in the other two cities, it may aisc reflect an increased general knowiedge among those referring and among feminist therapists themselves of what a feminist therapisi is. Aithough 86 potential feminist therapists were not sent questionnaires because of time limitations and therefore not included in the sample frame, there is no reason to doubt that their responses, proportionateiy, to the question of whether or not they considered themselves a feminist therapist would differ from those who were surveyed because their names were obtained utilizing the same process. In fact, therapists whose names were outained (as these were) from other returned questionnaires were even more likely to be feminist therapists than those whose names were obtained through other means of entry into the natural helpirig retwork. In other words, feminist therapists were the most accurate source for locating other feminist therāpists. 
of the 175 questionnaires in the adjusted maj7ing, 134 vere returned, for a 77 percent return rate. Table III illustrates the questionnaires returned.

TABLE III

QUESTIONNAIRE RESPONSES BY PERCENTAGE

\begin{tabular}{lccccc}
\hline & $\begin{array}{l}\text { Adjusted } \\
\text { Mailing }\end{array}$ & $\begin{array}{l}\text { Questionnaires } \\
\text { Returned }\end{array}$ & $\begin{array}{l}\text { Percent } \\
\text { Returned }\end{array}$ & $\begin{array}{l}\text { No } \\
\text { Response }\end{array}$ & $\begin{array}{l}\text { as Pesponses } \\
\text { Adjusted } \\
\text { Mailing }\end{array}$ \\
\hline Portland & 37 & 36 & $97 \%$ & 7 & $3 \%$ \\
Seattle & 51 & 40 & $78 \%$ & 11 & $22 \%$ \\
Bay Area & 87 & 59 & $68 \%$ & 28 & $32 \%$ \\
Totals & 175 & 135 & $77 \%$ & 40 & $23 \%$ \\
\hline
\end{tabular}

A11 non-respondents wiere contacted either by telephone or by postcard. As in the problem with the inappropriate mailings, many questionnaires were sent to groups whose functions and/or existence was urcertain, and in which the individual memsers were not known, either by name or number. As Table IV indicates, 73 percerit of the non-respondents were in groups or collectives. This trend is particularly evident in the Bay Area, whose 28 non-responderits composed 70 percent of the total non-respondents.

The non-respondents were sampled to ascertain their reasons for not returning the questionaires and to determine whether there was a non-response bias. Sixteen of the 40 non-respondents were accounted for: the one in Portland, three in Seatte, and 12 in the Bay Area. 
TABLE IV

NON-RESPONDENTS IN GROUPS SY PERCENTAGE

\begin{tabular}{lccc}
\hline & $\begin{array}{l}\text { Number of } \\
\text { Non-Respondents }\end{array}$ & $\begin{array}{l}\text { Number of } \\
\text { Non-Respondents } \\
\text { in groups }\end{array}$ & $\begin{array}{l}\text { Percent of } \\
\text { Non-Respondents } \\
\text { in groups }\end{array}$ \\
\hline Portland & 1 & - & - \\
Seattle & 11 & 8 & $73 \%$ \\
Bay Area & 28 & 21 & $75 \%$ \\
Totals & 40 & 29 & $73 \%$ \\
\hline
\end{tabular}

Examples of their responses expiain the non-responses. One woman said she had received the questionnaire and, not being sure what the term "feminist therapy" meant, had set it aside to think about it, and lost it. Another assumed it was an advertisement and threw it out. One said she was in a "spaced-out place" when it came and thus didn't respond. An example from the Bay Area illustrates some of tine problems invoived in mailings to unknown groups. Four questionnaires were sent to a Berkeley Feminist Counseling Collective listed by the San Francisco Women's Switchboard at one address and three questionnaires to a Berkeley Feminist Therapy collective isted on a returned questionnaire at another address. There was no response to a postcard to each asking that the questionnaires be returned. While in the Bay Area, a representative of the group was finally located, and she said that the two groups were actua?iy the same. When asked why the questionnaires had not been returned, she said she was too busy and besides she was skeptical of universities and people from universities. Parenthetically, she 
added that the collective had broken un anymay. These 16 ron-respondents were coded as to what their reply would have been to the first guestion on the questionmaire, as shown in Table $V$.

\section{TABLE $V$}

SAMPLING OF NON-RESPONDENTS

\begin{tabular}{|c|c|c|c|c|c|c|}
\hline & \multirow{2}{*}{$\begin{array}{l}\text { Number of } \\
\text { Unreturned } \\
\text { Question.. } \\
\text { naires }\end{array}$} & \multirow{2}{*}{$\begin{array}{l}\text { Number of } \\
\text { Unreturned } \\
\text { Question- } \\
\text { naires } \\
\text { Sampled }\end{array}$} & \multicolumn{3}{|c|}{$\begin{array}{l}\text { Responses to } \\
\text { Question } 1\end{array}$} & \multirow{2}{*}{$\begin{array}{l}\text { Question- } \\
\text { naire not } \\
\text { Applicable }\end{array}$} \\
\hline & & & Yes & No & know & \\
\hline Portland & 1 & 1 & - & - & 1 & - \\
\hline Seattie & 11 & 3 & 3 & - & - & - \\
\hline Bay Area & 28 & 12 & 3 & 1 & - & 8 \\
\hline Totais & 40 & 16 & 6 & 1 & 1 & 8 \\
\hline
\end{tabular}

From this information, it does seem that the non-respondents were feminist therapists and that the non-resporises were largely a factor of lost, discarded and non-applicable questionnaires and not because those not resporiding were not feminist therapists or were unsure. Therefore, it is concluded that the generailizablity of the results are not influenced by any rori-response biàs.

Those therapists returning the questionnaire and indicating "yes" on question 1-..that they consiciered thenselves to be a feminist therapist-constituted the sample frame, the available part of the population.?

70ne femirist therapist in the Eay Area wir did not meet the criteria for inclusion in the sample frame because she was enrolled in school and functioned in ro other practice setting excopt a field piacement was eliminated at this point, leaving 104 feminist therapists in the sanple frame. 
Using a random number table, a 20 percent sample was drawn fron the samp?e frame of five feminist therapists in Portland, six in Seattle, and nire in the Bay Area. All who returned cuestionnaires were notified oy mail that their response had been received and was appreciated and were told whether tney would or would not te contacted for ir irterview (see Appendix 6). A list of feminist therapists in Portland and Seatite was compiled and sent to respondents in those two cities because of the lack of centralized referral processes there.

\section{INSTRUMENT FOR DATA COLLECTION}

The initial stages of instrument design involved familiarization with the literature in the fieid (summarized in Chapter II), with particular focus on: 1) possibie instruments which could provide a means to discriminate feminisis from each other on the basis, perhaps, of political views or positions on issues related to the feminist movement; and 2) areâs of potential consensus and areas of potential disagreement raised in the literature, in particliar as related to feminist therapy. A11 instruments encountered in the literature, however, were designed to separate feminists from norimfeminists or supporters of women's liberation from opposers of women's liberation rather than any internal differentiations among feminists (Acker 1974; Dempewoiff 1974a; Rosenkrantz, et al., 1968; Steinmann 1974; Tavris 1972). In addition, most of these studies were designed in 1970 and 1971, and were felt to reflect attitudes about what it meant to be a feminist four to five years ago (i.e., whether or not a moman shaves her iegs; Acker 1974) rather than any reflection of contemporary 
issues, concerns, and divisions within the vomen's movemert.

For these reasons, the decision was made to develop oper-ended questions based on issues raised by the literature review itself, and in the analysis, proceed from there to possible categorizations and correlations based on the data obtained from the interviews rather than attempting to inciude any one closed question or series of questions taken fron previous studies. Six main topic questions were deveroped:

1) Who are the feminist therapists?

2) What is the range of techniques utilized in feminist therapy and what are the new techniques or variations on traditiona? techniques being developed?

3) How do feminist therapists describe their own feminist therapy?

4) What are the theoretical orientations and positions of feminist therapy?

5) What are the attitudes of feminist therapists toward feminism and toward therapy?

6) How do feminist therapists define feminisiri and feminist therapy?

All relevant issues raised by the literature review, consultations, and brain-storming were listed urder the appropriate topic heading. Information for the first topic area was to come from both the questionnaire analysis and the interview, while information for the other topic areas was to be prouided by the interviek. Eifort was conceritrated on developing a series of broader, more carefully designed questions which would subsume the more specific questions. A schenatic representation of the interview, iilustrating the six broad topic areas, the interview format of general questions followed by probes in each category, and the information the questions were designed to elicit, is included in Appendix D. During the interview, certain probes generally required 
more elaboration than is indicated, and where this was the case, the form of the elabcration is explained in Chapter IV.

Before the final interview fom was arrived ot, the interview was piloted with three Portiand feninist therapists in the sample frame but not in the sample itself. Extensive feedback from the interviewees followed each interview. The primary informetion gained from the pilots was that the qusstions were answerabie, that they elicited appropriate responses (i.e., they "made sense"), and that they did in fact generate the type of information desired for the study. Since this was the case, inputs from these women that the questions were at times vague and "hard to get handles on" did rot lead to specific changes in the questions per se but were incorpcrated into an introduction given by the interviewer prior to each interview, as follows:

The feedback I've gotten from other women I've interviewed has been that some of the questions seem hard to get hand?es on or difficult to focus. I've kept them in the interview nonetheless because I've felt so good about the information I've gotten anyway. But it's OK with me if you don't have an answer a11 "figured out"--I don't my'self. I feel rea? comfortable with your sharing your ambivalences and am as interested in the process you may go through in deciding how to answer as "an" ansiver.

As an additional part of the introduction, permission was requested (and received) for taping each interview. A final question asked for interviewee feedback on doirg the interview was added at the end.

\section{DATA COLLECTION}

Those 20 therapists identifying themseives as feminist therapists on the intial questionnaire and comprising the sample were notified by letter. Interviews were scheduled in Seattle on February 27 and 28 , 
in Portiand March 3-7 and April 4 , and in the Bay Area March 12-17, 1975. In addition to the interviews with the feminist therapists in the sample in the Bay Area, an interview was also done with two women irvolved with the Berkeley Women's Center's Feminist Counseling Coliective, which functions as a feminist therapist screening and referral service. A sumnation of this interview is inciuded as Appendix E because of a growing interest among women in finding femirist therapists and/or in setting up such a service.

In preparing the initial thesis prospectus, attemipts had been made to obtain funding with which to compensate the therapists interviewed for their time, on the assumption that many of them were working on a subsistence level. Funding was never obtained, and its lack did not seem in any way to affect the villingness of those sent questionnaires (over 90 percent of whom indicated they were willing to be interviewed) or selected for the sample to be interviewed. Those interviewed were assured that they mould receive a sumination of the resdits of the stidy, and this sesmed a "fair trade" for their time. Those interviewed seemed oper, and eager to participate? in the study and to share what they were doing. This impression is further validated by the feedback received after each interview, presented at the end of this section.

All interviews were completed as scheduled. The original time estinate of an hour, based on the iength of the pilot interviews, was too short. The actual interviews ranged in length from an hour and 15 minutes to close to two hours. Ail interviews nere tape-recorded to free the interviewer for attention to the content of responses and the interview process. 
Gne of the women in the Eay Arta sample had decided, aftar returning the questionnaire inaicating she identified herself as a feminist therapist, that she did not feel that the Tabel applied to the way she currently funct: ons in her positicn at a conriunity mental health clinic. For her, feminist therapy was a type of therapy she could offer and would enjoy doing if someone she were seeing wanted that kind of consciousness. However, because she works in a pubiic agency, she feels a responsibility to deai with "anybody who comes in the door whether or not their consciousness is sufficiently raised"i for her to do feminist therapy, and therefore she will often "iet it drop." Aithough this interview was completed, her responses have not been included in the analysis of the findings. A similar situation occurred when one of the women in the fortland sample was interviewed. She reiterated several times throughout the interview that although she had indicated on the questionnaire that she was a feminist therapist, she really wasn't sure that she was one. Ir response to the interview question asking for her definition of feninism and ferninist therapy, she replied:

That's what I can't detine for you. That's why I can't say to you, "Yes, "I'm a feminist therapist." I put 2 question mark there. . . I I need some more time to get it really clear.

A later telephone contact confirned her somewhat ambivalent position. Because those who returned questionnaires indicating they were "not sure" if they were feminist therapists or not were not included in the sample frame, the information from this interview was also not 
included in the data analysis.8

A research question raised by these two interviews is whether the responses and practice of these two women and others like them differ significantly from those who identify themselves as feminist therapists. However, this is a peripheral issue to the primary purpose of this study, which is an exploration of ferrinist therapy rather than a comparison of feminist and non-feminist therapists, and therefore the comparison has not been pursued.

Finally, one woman in the Bay frea sample invited a colleagle who was also a feminist therapist (one whose name had been received after January 15 and therefore not sent a questionnaire) to join us for the interview. Her responses have been included in the data aralysis. The final interview data allalyzed, then, consists of interviavs with 19 feminist therapisis: four in Fortiand, six ir seattle, and nine in the Bay Area.

Vidich (1970:172) writes:

Data collection does not take place in a vacuum.

Perspectives and perceptions of social reality are shaped by the social position and interests of both the observed and observer [or interviewer and interviewee] as they live through a passing present.

Given this position, it is important to consider here two aspects of the interview process which have potential impacts on the data received. in particular as they relate to the question of bias. The first

8 Since both of these women responded on the questionnaire that they considered themselves feminist therapists, those figures reporied previously in this chapter have not been changed, and their questionnaires are included in the questionnaire andysis in chapter 11. Section I. 
developed because of a minor change after the eighth interview in the process by which the interview was conducted. Previcusly, the researcher nad asked the questions and the interviewee/feminist therapist had responded. Beginning with the interviews in the Bay Area, a duplicate copy of the questions and their probes as used by the interviewer were given to the therapist when the interview began. The actual idea of making this change occurred spontaneousiy, but it was continued becalise it seemed to incorporate into the interview process the interviewer's own feminist value of mitigating as much as possibie structured power differentials. The concern that this change might bias the results was considered, particularly with regard to the validity of questions designed to generate responses (for example, "What do you do with your feminism in therapy?" and "What does a person get from you that she wouldn't get from sameone who wasn't a feminist therapist?") when potential responses (at least from the point of view of the researcher) were listed as probes. However, a comparison of responses to these open-ended questions before the interview was shared and after does not validate this concern. In both cases, replies were often received which were not inciuded as probes; and in those interviews in which the questions were shared, probes were at times considered aioud by the interviewee as possible responses and then disagreed with or dismissed.

The larger issue here, however, goes beyond specific responses on specific questions to the biases potentially infierent ini the overall interview process itself. From the initial contact on, the bias of the researcher was clearly in the direction of supporting, being influenced by, and wanting to bocome more involved with feminist therapy. The 
introductory letter accomparying the initial questionnaire, in explaining the rationale for the topic itself, said:

That choice [to do a thesis on feminist therapy] has grown out of my own experiences and needs. Eeing in therapy myself with a woman consciolis of feminist concerns was very important for me. Currently, I see primarily women in the college's student counseling center, and ain attempting to bring to that situation a similar conscicusness. However. I feei a real need to know what other women are trinking, directions they are moving, and way's they are merging theory and practice.

Similarly, throughout the interview, the researcher, while attempting to focus the interview on the interviawee, did at times make coments and share experiences which indicated if not her position on an issue at least her concerns. To a certain extent, even the design of the interview itself could be seen in this light. Although based on a review of the literature and pretested to uncover omissions, nonetheless at some poirit processes such as choosing which issues to probe on cannet help but reflect one's theoretical pcsition. This question of whether there is any shift of the data toward the researcher's position vis a vis feminism could be compounded by emphasis at times in recent socialpolitical movements for people to be "more radical/militart/feminist than thou." In other words, there can be at times a pressure to appear more (or at least no less) radical (or feminist) than those around a person, and in fact to present onese if as more radical (feminist) than one actually is (Keriston 1968, 1971). in fact, one feminist therapist directly acknowledged this pressure and several alluded to its impacts on their clients (the feminist "parent" or "shouid," discussed in Chapter IV, Section III, Other Comments on Feminism). 
Because of the researcher's clearly pro-feminist and pro-feminist therapy position, ore could argue that the participants in the study responded to what they" thought they "ought" to say and what they thought the researcher wanted to hear. This criticism, however, fails to look at the larger dynamics of interview process. In both instances above, what the interviewer did not do is as apt to distort or project bias as what she did do, and vice versa. In other words, while sharing the questions could be criticized for its possible influence on intervicwee replies, a similar and equaily strong argumeni could be made--although it is rareiy done--about the impacts and value statements made by the interviewer not sharing with the interviewee.

Vidich (1970:169-170) argues that the problem of a rasearcher's conscious identification with the groups, causes, or issues being studied can be perceived similarly, again from the position that "complete and total neutrality is extremely difficult, if not impossibie, to assume." He continues:

Neutrality even to the point of total silence is a form of reaction and rot oniy will be considered as such by all parties. . but also implies a specific attitude toward the issue--being above it, outside it, more important than it, not interested in it. Whatever meaning respondents attach to neutrality will, henceforth, be used as a further basis for response. This is true even when respondents demand an opinion or approval in structured interview situations. Failure to make a commitment can create resentment, hostility and anta. gonism just as easily as taking a stand. In both cases, but each in its own way, relationships will be altered and, herce, data will be affected.

Becker (1970) similarly states that research uncontaminated by personal and political sympathies is impossible and that there is no position from which sociological research can be done that is not biased in one way or arother. 
Although there is no control group with whon to compare the possible effects of the bias inherent in the research as it was designed and conducted or in the minds of those interviewed, the responses themseives can to some degree respond to these concerns. First, wheri it came to the specific questions as to what constituted feminist: therapy, few if any of those interviewed agreed totally with ali tho informa? hypotheses of the researcher: things she by her definition considered important aspects of feminist therapy the feminist therapists seemed just as likeiy to feel had nothing to do with feminist therapy, and vice versa. Secondly, it is the researcher's cbservation that women whose position was less "radical" seemed open and willing to present their own positions, often acknowledging their differences from those they perceived to te "more feminist" or at ieast "more radical" than they were, noting to which of their statoments they thought others would take exception, and at times disagreeing with the focus, ideas or perspectives of other feminists. Personality characteristics of feminists cited in Chapter is (under The Rise of the Second Wave of Feminism) which found security about self-worth, independence of judgment, and the ability to resist group pressures, seem demonstrated here.

In general, the interviews followed fairly closely the order of the questions in Appendix D. If, while answering one question, another question generaliy raised later on in the interview seemed appiicabie, the interviewer brought it in at that point. The interviewer attempted to maintain a role of ciarifying questions, re-focusing the interview, monitoring for clarity and congruency, and supporting the interviewee with the feedback that her responses were understandable, acceptable, 
arid helpful.

As the interviews progressed, it becaine more apparent that it was necessary to constantly probe ior differentiations between what a person did because of her training or personality and what she did because of her feminism. For example, when asked if she self-disciosed, a feninist therapist might respond with a strongly affirmative comment. However, if then asked, "Does that have anything to do with your feminism (or boing a feminist therapist)?" she might respond regatively, as one did saying, "That I think I wouid do whether I was a feminist or not." As soon as the interviewer became more aware that a therapist affirming she behaved in a certain way did not necessarily explain why she did it, more attention was paid in the interview to clarirying this.

The interview process also surfaced a riumber of questions which were not included in the interview and in retrospect might well have been. Some issues alluded to by feminist therapists in answering questions could have been asked more directly, specirically whether a feminist therapist had to labei herself a feminist; whether they saw differences between feminist therapy, a therapist who was a feminist and fentinism as therapy; and whether women clients should be seeing women (or femirist) therapists. The issue of therapeutic directiveness was discussed by almost all interviewees at some point, and could have been developed into a usefur question. A series of questions could have been deveroper to further determine attitudes about how feminist therapists perceived American society and nental health, posing, for example, the assertion that no woman car be healthy in an unneal thy society and therefore that therapy runs the danger of supporting and encouraging adaption to that, 
unhealthy system. A related guestion could have raised the issue of what feminist therapists see as a change of focus-mi.e., sexual inequalities vs. economic inequalities. The original question on professiorialism might in retrospect have been refoclisea to include more currerit issues, which in the Bay Area were activated at a recent confer.. ence on Women and Mental Health when the idea of a union for all feminist niental health workers-mprofessionals and nonprofessiunals alike-was heatediy debated. Firâlly, the question on diagnosis could have been replaced by a question asking imminis tharapists to compare various theoretical orientations (i.e., Freudian, Gestait, etc.), particularly as they related to women.

Feedback reczived from interviewees was high?y positive. They said they enjoyed the interview and moreover, that the interview process (or anticipation of the interviex') provoked a reclarification in their own minds of what feminist therapy was or reactivated issues for them. As one woman said:

I erijoyed the questions. I liked the things thay made me think about and liked ever the tension I experienced a couple of times wher, I realized, "I don't have an opinion about that one. No . . I Car't thirk of anything." I thought, "hy God. I must be missing something." It was sort of nice to feel, "Look, this may be an area i can look at." It's very easy to get very self-contained and do my own thing and not get. stuff coming in. So this sort of thing feeds me. This is really nurturing for me.

\section{DATA ANALYSIS}

The material for data analysis is in two forms: the information from the questionnaires received from the entire sample frame, and information from the interviews with a random sample of the sample frame, 
the latter providing the bulk of the research data. Data anajysis itself proceeded in two stages. The first involved analysis of the questionnaire and of each interview question, and the second stage involved deveropment of five main questions into which the guestionnaire analysis and interview questions were re-grouped and at times synthesized.

The questionnaires provided information about the characteristics of all the feminist therapists in the sample frame, generalizable to the population as a whole. It provided information about the theoretical orientations, length of timie doing therapy, highest degree attained and field of degree, focus of practice, mode of practice, practice setting, and area of specialization of the feminist therapists in the sample frame. Initial analysis of the information fron the questionnaires involved tabulating the data received in each category to determine general population characteristics, with particular attention to differences, if any, among the three metropolitan areas. Perusal of this information revealed a wider range than had been expected of years of practice and degree levels, and so comparisons were made with these as the independent variables. Some possible comparisons between such characteristics as theoretical orientation or focus (especially women) and other characteristics could not be charted because of multiple responses on each heading. A.1so, because of the riumber of guestions for which more than one reply was possible, traditiona? forms of analysis for significart relations were noi utilized, and totals were instead expressed in percentages and compared visuaijy.

Freparatory to actua? data anings is of the information obtained from the interviays was the task of transcribing the 22 hours of casette 
tapes on which the interviews were recorded. This was a much more tedious and time-consuming process than had been anticipated, and yet it was felt that these verbatim transcriptions of the interviews themselves were necessary to provide tre detailed infomation needed for the interview anaiysis.

Aside from onssions of clearly extraneous materia? and occasiona? inaudibie phrases, the interviews were transcribed as completely and accurately as possible, cuiminating in iez single-spaced pages of typewritten material. This document was copied and the original was cut. apart into sections, with the conplete responses to cach interview question (with each probe viewed as a scparate question) constituting a section. The sections were sorted into folders so that all resporses to each question were grouped together.

This first stage of data analysis of information from the interyiews involved the development of categories of responses by location of thematic response clusters among the replies to each question. Categories for some questions were mutually exclusive; on cther questions responses overlapped catecories (this overiap or inclusiveness of replies is indicated in the discussion of each question). Responses were sorted into the appropriate category or categories, and each category was summarized, focusing both on commonalities arid, where indicated, differences within each category. If there were comments extraneous to the previously defined categeries or question quaifications, these were aiso sumarized ard included in the analysis or refired for analysis under a future question. In all, the 25 questioris (as indicated 
ir. Appendix $D^{9}$ ) were analyzed in this fashion.

In general, each woman responded to each question except in several instances when the researcher inadvertantly omitted a probe and during the last third of the interview which involved the two therapists together when the tape recorder did not record. Some probes were spontaneousiy answered (or partially ariswered) in replies to earlie: questions, and when this was the case, they were re-sorted as necessary. The findings indicate the total number of feminist therapists repiying to each question as it is considered.

The questionnaire analysis and the 25 interview and probe questions, while originally designed to stand alone, were found to be difficult to understand or to synthesize in any context, even when arranged within the six original questions on which the interview was based. Therefore, five new questions, seen as more focused and yet more encompassing while less repetitive, were deveioped:

1) Who are the feminist therapists?

2) How do feminist therapists define feminism?

3) What is feminist therapy?

4) How does feminist therapy perceive and incorporate therapeutic issues?

5) How does feminist therapy perceive and incorporate feminist issues?

The 25 interview guestions as well as the questiamaire analysis were then re-sorted into these five categories. Sometines, two or more interview questions (or portions of questions) were synthesized and

9 The numbers following each interview question and interview probe indicate the groupings used in the original daia analysis. For example, while oulestion 2 ws composed cf only ore probe, ouestion 23 was composed of one interview question and three probes. 
retitled. For example, although designed to generate different inform mation, the two interview questions, "What do you do with your feminism in therapy?" and "What does a person get from you t'ia's she wouldn't get from someone who wasn't a feminist therapist?" ir; ract eicited very similar information. Therefore. as part of the information explaining the third category above, "what is feminist therapy?" they were synthesized to produce a subsection of that category entitled Descriptions of Feminist Therapy. Other original interview questiols, particuiariy, "Can you give an example of a time when it was hard for you to incorporate your feminism and your therapy?" and "Are there other questions, issues, or struggles for you right now in combining feminism and therapy?" were divided and incorporated into several categories. Some information, such as the criticisms of feminism discussed as part of the second category, were gathered from throughout the various interview questions ratiner than being responses to one question. Chapter IV presents synthesized responses to interview questions (and the questionnaire analysis) in each of the five categories. An introductory section preceding discussion of responses in each category explains which interview questions are incorporated into that category. All quotations cited are verbatin transcriptions from the tape-recorded interviews with minor modifications for flow (i.e., omission of "kind of" and "and"), and occasional sentence transpositions. The quotations are identified by fictitious names to provide confidentiality and yet enable one person's responses to be followed throughout the data anaiysis. 
CHAPTER IV

\section{FINDINGS}

\section{WHO ARE THE FEMINIST THERAPISTS}

Information arswering this question includes the analys is of the questionnaires returned by all members of the sample frame, and answers to the intervievi questions, "Did you become a feminist first and then a therapist or a therapist first and then a feminist?" (as Personal Histories of Feminism); and, "lihat percent of your time do you spend doing therapy?" (Time Allocation). Anso included are several portraits of individual feminist therapists interviewed.

\section{Questionnaire Analysis}

This aspect of the data analysis includes the tabulated results from the 104 questionnaires composing the sample fiame: 25 in Portland, 30 in Seattie, and 49 in the Bay Area. Since not 311 respondents answered ail questions on the cusstionaire, percentages are calculated in terms of the actual numbers of responses to that question.

Theoreticai Orientation. This question asked the respondent to indicate her general theoretical orientation, apart from her feminisin. The instructions indicated that one should check all categories winich applied and add ary not listed, with the result being that responses ranged from ore item checked to as many as 14 , the mean being four. This in itself indicates the diversity of theoretical orientations held 
by any one feminist therapist. Table $V I$ indicates the responses checked, ranked by the percentage of respondents indicating this orientation.

TABLE VI

THEORETICAL ORIENTATICNS OF FEMINIST THERAPISTS

\begin{tabular}{|c|c|c|c|c|c|}
\hline & \multicolumn{2}{|c|}{$\begin{array}{l}\text { Respondents } \\
\text { Indicating }\end{array}$} & & \multicolumn{2}{|c|}{$\begin{array}{l}\text { Respondents } \\
\text { Indicating }\end{array}$} \\
\hline & $\#$ & $\%$ & & \# & $\%$ \\
\hline Eclectic & 74 & $72 \%$ & Co-counseling & 12 & $12 \%$ \\
\hline Gestalt & 63 & $61 \%$ & Jungian & 12 & $12 \%$ \\
\hline Humanistic & 46 & $45 \%$ & Radical therapy & 11 & $17 \%$ \\
\hline Transactiona! & & & Adlerian & 4 & $4 \%$ \\
\hline analys is & 36 & $35 \%$ & Mutual goal & & \\
\hline Assertive training & 33 & $32 \%$ & setting & 4 & $4 \%$ \\
\hline Psychodynamic & 29 & $28 \%$ & Primal & 3 & $3 \%$ \\
\hline Behaviorism & 23 & $22 \%$ & Learning theory & 3 & $3 \%$ \\
\hline Bioenergetics & 20 & $19 \%$ & Family therapy & 3 & $3 \%$ \\
\hline Rogerian & 18 & $17 \%$ & Social casework & 1 & $1 \%$ \\
\hline Freudian & 17 & $17 \%$ & All others & 16 & $16 \%$ \\
\hline Reichian & 14 & $14 \%$ & & & \\
\hline
\end{tabular}

The "others" included Assagioli's psychosynthesis. Wolpe's relaxation, Don Juan, psychodrama, reality therapy, massage, experiential, existential, self-heaiing, music therapy, body work, "my own developing theory re. vomeri," and "a model our coliective has developed."

Distribution of responses by areas shows a fairly similar ranking in each, with "eclectic" consistently the most frequently indicated, followed by "Gestalt." Certain orientations received different percentages of adherents in each city. For example, no orie in Fortiand indicated radical therapy as a theoretical orientation, whereas 13 percent did in Seattle and 75 percent did in the Bay Area. Thirty-five percent of Bay Area respondents indicated a Froudian theoretical orientation, as 
compared to only 7 percent in Seattle and 4 percent in fortland. Therefore, for further comparison, the theoretical orientations were grouped in three categories: Traditional (including Adlerian, Freudian, Jungian, psychodynamic, and social casework); Eclect.ic/Humanistic; and Avant-Garde (including assertive training, bioenergetics, co-counseling, family therapy, Gestält, learning theory, mutual goal setting, primal therapy, radical therapy, Reichian, TA, ana all others). Despite any area differences in particular orientations, feminist therapists in the three areas surveyed differed only minimally in their adherence to the three groupings of theoretical orientations. Traditional replies were, interestingly, somewhat greater in the Bay Area, with a corresponding decrease in Avant-Garde replies. This was contrary to expectations that the Bay Area would be more "in touch" with recent therapeutic innovations and consequertly more Avant-Garde in theoreticôl orientation than Portland or Seattie. Of the theoretical orieritations checked, 19 percent were Traditional, 27 percent were Eclectic/Humanistic, and 54 percent were Avarit-Garde. Clearly, the overali propensity amorg feminist therapists in the three areas studied is for thecretical orientations which are newer ard/or non-traditional.

Length of Time Doing Therapy. The next question asked, "How long have you been doing therapy (total time, whether feminist or not)?" The responses ranged from three months to 29 years, with the mean being 6.32 years and the median five years. An analys is of variance found the difference by areas not to be significant. When the responses were clustered, 29 percent had been doing therapy for two years or less, 44 percent for three to six years, 17 percent for seven to 14 years, 
and 10 percent for 15 years or more. Although this seems to show that feminist therapy is done by those in practice six years or less, it is interesting that those wich some experience (six years) are more representative than those with less, and that those with more experience, particularly those with 15 years or more, do comprise a portion of the population.

Degree Attained. Respondents indicated their degree level, as shown in Table VII. For coaing purposes, only the highest degree wâs tabulated.

TABLE VII

DEGREE L.EVELS OF FEMINIST THERAPISTS

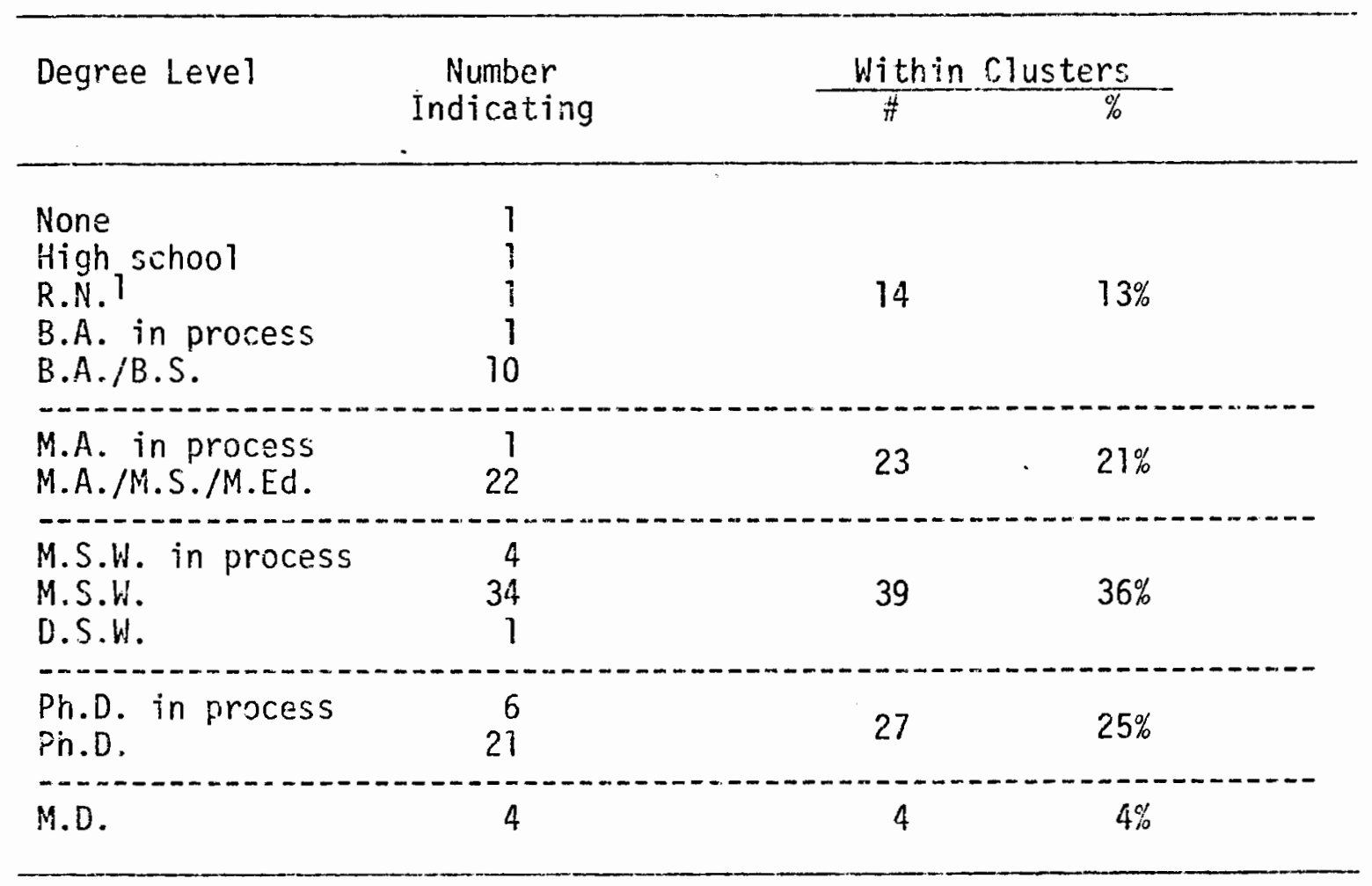

${ }^{1}$ There were five R.N.S in the sample frame, but four had B.S.S or M.S.S as well, and were tallied there. 
Except for Portland, where there is one more person with a Ph.D. than with an M.S.W., the Master's degree in Social Work (including here one D.S.W. and four M.S.W.S in process) is the most common degree held by feminist therapists in the sample frame. At the B.A. Tevel, major fieids ranged from psychology to drama, and included math, nursing, English, and education as well. At the Master's level, major fields ranged from psychology (held by 12 respondents) to English, and inclucied Gestalt processes, sociology, nursing, and music therapy as we 11 . Ph.D.S were generally in psychology, with one in counseling and one in psychobiology. The M.D.s were in psychiatry. of note is the wide range of degree fields among feminist therapists at the B.A. and M.A. levels.

Focus and Mode of Practice. This question was initially designed to differentiate among clientele focuses (i.e., women only, couples, etc.) and primary modalities for doing therapy (i.e., individually, groups, consultations). However, because the instructions again toid respondents to check all applicable catetories, some therefore checked all six focuses and all six modes listed. Thus, information about primary focus or mode is not as clear as would have been desired. In retrospect, instructions to indicate the focus and the mode or to indicate percentages for each (DuBois 1975) would have generated more useful information here. Tables VIII and IK illustrate responses to the question, "What is the focus of your practice?" "Women" are the most frequently listed focus, followed by "couples" and "women and men" both. There is little difference hetween those indicating they work with individuals ard thuse who work with groups; many do both. The 
FOCUSES OF PRACTICE AMONG FEMINIST THERAPISTS

\begin{tabular}{lcc}
\hline Practice Focuses & Number & Percent \\
\hline Children & 17 & $6 \%$ \\
Adolescents & 28 & $9 \%$ \\
Women & 78 & $26 \%$ \\
Lesbian women & 32 & $11 \%$ \\
Families & 31 & $11 \%$ \\
Couples & 53 & $18 \%$ \\
Women and men both & 52 & $18 \%$ \\
Other (young adults, parents, & & \\
prisoners, communes) & 4 & $1 \%$ \\
\hline
\end{tabular}

TABLE IX

MODES OF PRACTICE AMONG FEMINIST THERAPISTS

\begin{tabular}{lcc}
\hline Modes of Practice & Number & Percent \\
\hline Individuals & 84 & $30 \%$ \\
Groups & 72 & $26 \%$ \\
Workshops & 39 & $14 \%$ \\
Training & 40 & $14 \%$ \\
Psychological testing & 12 & $4 \%$ \\
Educational/vocational testing, & 16 & $6 \%$ \\
$\quad$ counseling & 7 & $3 \%$ \\
Teaching, writing, iecturing & 2 & $1 \%$ \\
Cominunity organizing (consultations, intakes, & 4 & $4 \%$ \\
\hline mediations) & 4 & \\
\hline
\end{tabular}

differences among areas are minimal, although, interestingly, the Bay Area is the only area where comanity organizing was mentioned as a mode of practice. The 13 women coded as "teaching, writing, lecturing," "community orgarizing," and "other" (including consultation, intake, and 
commune mediation) give some overview of the range of modes considered by feminist therapists to be part of the ir therapy (discussed further in Section III, Qualifications About Feminist Therapy, of this chapter).

The problem with analyzing this data is that respondents did not gererally indicate, in the cases of children, adolescents, couples and families, if there is a focus in terms of the sex of those seen, although several did indicate they sâw only female adolescents or lesbian couples. Although "worien" and "women and men" were interded to be mutually exclusive categories, some checked both. In an attempt to determine those feminist therapists who do focus on women oniy, a tally was made of those who checked "women" and/or "Jesbian worien," but not "women and men." This produced a figure of 45 percent of the sample frame who focus on or see oniy women, and is perhaps more meaningful as an indication of practice focus than the 25 percent who checked "women" as a focus above.

Practice Setting. This question listed five possible practice settings, asking the respordent to incicate which applied to her. Again, many checked more than one (but not more than three) practice setiings. "Priväte agency" was inadvertently omitted as a pussible choice. Although a number of feminist therapists indicated that this was the setting in which they worked, more might have had it been included. Settings such as Womer,'s Certer, Outside In (drop-in health arid couriseling center for transient youth), Counseling Center for Sexual Minorities, ard Solo Center (resource certer for single and divorced adults) were listed by five respondents and included under private agencies, although as "alternative institutions" they may be more like 
private practice settings or collectives. Table $X$ shows the practice settings in which feminist therapists indicated they worked.

TABLE. $X$

PRACTICE SETTINGS OF FEMINIST THERAPISTS

\begin{tabular}{lcc}
\hline Practice Setting & Number & Percent \\
\hline Private practice & 63 & $39 \%$ \\
Public asency & 31 & $19 \%$ \\
College or university faculty or staff & 24 & $15 \%$ \\
Collective & 18 & $11 \%$ \\
Enrolled in school or psychiatric & 10 & $6 \%$ \\
residency & 13 & $8 \%$ \\
Private agency & 3 & $2 \%$ \\
Other & 1 & $1 \%$ \\
\hline
\end{tabular}

Private practice is the most frequently indicated practice setting, utilized by over a third of the feminist therapists. In comparisons by area, Portiand has a higher percentage of feminist therapists working for public and private agencies and enrolled in school and correspondingly less in private practice, while seattle has more on the staffs or faculties of colleges or universities. The percentage of those indicating private practice is highest in the Bay Area, as is membership in a collective, which seems to be almost entirely a Bay Area phenomenon.

Area of Specialization. This question asked, "Do you specialize in a particular area(s) or problems?" Approximately half indicated they did, and those checking "yes" were asked to indicate their areas of specialization. The riajority (28) listed a specialization particularly involving women, including carser counseling for women, rape, women in 
the middie years, women in the process of divarce, single women, women in conflict re. childbearing, and feminists with problems of integrating feminism, its values and heightened consciousness, into their lives. The next nost frequently mentioned area of specialization was sexuality, indicated by 11 women and including sexual dysfunction, sexual icientity, and groups for pre-orgasmic women. Eight therapists indicated a focus on particular techriques, such as assertive training, massage, art therapy, and feninist body work. Other areas of specialization listed included drug and alcohol abuse and addiction (listed by five), obesity, depression, low self-esteem, intimacy, large group relationship problems, alternative 1 ifestyle and adjustmient, women's therapy referral counseling, advising a lesbian resource center, teâching women's studies, and training paraprofessionals. Again, as in the resporises to the question about theoretical crientations, in viewing these responses what is apparent is the diversity and lack of traditionality in the areas of specialization chosen by feminist therapists.

Comparisons. A series of grids were developed, enabling resporises on one question to be compared to those on another. In comparing theoretical orientation to degree, those with the least formal education (B.A. or less) report the most Avant-Garde theoretical orientations. Looking at social workers as compared to feminist therapists at other degree levels, they seom to be somewhat more traditional in orientation than M.A.S and slightly less traditional and more Avant-Garde than Ph.D.s. In comparing theoretical orientation to years of practice, there is remarkabiy littie difference between those in practice 0-2 years. 3-6 years, or more than 15 years. Despite what may be expected, those in 
practice 15 years and longer are no more Traditional and no less Avant-Garde than those much more recertly beginning to practice. Those with less academic training (i.e., B.A.s and less) tend to be in practice for less than the mean or median figures for all feminist therapists. Except for psychoiogicâ? testing, done as wou?d be expected primarily by Ph.D. psychologists, other modes of feminist therapy differ little by the degree of the feminist therapist. Those feminist therapists with B.A.s or less are the most ijkely group to be in private practice and the most likely to be members of a collective. Social workers are the most likely to be employed by a public agency, more likely than M.A.s or Ph.D.s to be in private practice, and the least likely to be oll a college or university faculty or staff and to be members of a collective.

In comparing length of time to focus, differences are smail. Those in practice 15 years or more are least apt to indicate "women and men." Correspondingly, those in practice the least amount of time are most likely to indicate "women" as a focus and least likely to indicate families and couples. Length of time in practice seems to have minimal effect on mode. Private practice and positions as college or university fáculty or staff increase as a feminist therapist's years of practice increase. On the other hand, those in practice the least number of years seem to be employed by public or private agencies or in school. Those in collectives are therapists practicing six years or less.

Personal Histories of Feminism

In response to the first interview question, "Did you becone a ferninist and then a therapist, or a therapist first and then a feminist?" 
the largest group of feminist therapists identified themseives as feminists before they hecame therapisis--cight of the sample of 19. of the other 11 women, six said they were therapists before becoming feminists while for five, becoming a reminist was concurrent with becoming a therapist.

Several themes run throughout all these histories, regardless of whether they were feminists first or therapists first. Perhaps the primary one is the impact of the events of the late sixties and early seventies on the consciousress and the lives of these women. For some, there was a sense of a support systemi where there had been none before, a serise of connectedness, a rame to feelings they had had but had felt alone in.

Throughout my life I've had, like so many women, the gnawing feeing that "this isn't enough; I don't fit into this role." But I didn't have a label and there weren't the words and there weren't the people to be supportive of that . . . before feminism came to the forefront.

(Sue)

0thers speak of growing awarenesses and realizations of the oppression of women, themselves included, of their own similarities ard commonalities with other women, and of the ways in which they were cooperating in their subjugation. This awareness was described by some as an intense and critical experience in their lives: "It fell on me like a ton of bricks when it happened" (Lesiie). "It was the most compact growth experience that I 've ever experienced" (Sue). "It was just like it happened aimost overnight" (Marsina). For a large group of the women in the sample (13 of 19), this consciousness was accompanied by or supportive of major chariges in life style, whether that was deciding to leave a marriage, to not get married, to go back go school in a field they had chosen, to becone 
involved in work that was meaningful to them, or to change a work setting or work form to one that was more supportive, congruent and often involved with women. At present, feminism is a profoundly important part of their lives. As one woman explained, "My feminisn! is totally integrated into the rest of my 1 ife. I do not separate myseif out, one activity from another. I feel that I express my feminisn 24 hours a day" (Teri).

Another theme is their perceptions of the impact of their developing feminism on their therapy, and vice versa. Obviously, the fact that a criterion for inclusion in the sample was that all of then identify themselves as feminist therapists means that some integration of feminism and therapy has occurred for all of them on one levei.

None of the eight women who were feminists first and then therapists saw a direct connection between their feminisn and their decision to become a therapist; if they did see any influence, they characterized it as "uricorscious" or as of secondary rather than central importance. For two, their increased awareness of their minority position as women and the implications of that secondary status led them to learn to do therapy as an attempt to understand their own "wounds" as women.

I believe that people become therapists. . out of their own sense of being wounded themselves, and trying to deal with that... That certainly is connected to my experierices of nyseif as a feminist, but, I don't think that is the central issue. . .-that's like an added thing. (Beth)

My choice to be a therapist didn't have lots to do with being a feminist, I don't believe, except maybe in the sense [that] if you're a member of some kind of minority, it you feel some kind of discomfort with the way the vorld is or the way people are [then] you try to figure that out. I'm sure my 
status as a women added [to what influenced me to become a therapist] but there were a lot of other influences... that were more important.

(ATice)

Four of these women who were feminists first perceived feminism to be connected with their becoming therapists in that it supported their rejection of the traditional roies their families and the society expected them to play as women and their decision to do "what I wanted for my own self" (Ann).

People in my famiiy go either into agriculture or secondary education. I was on the track to being an English teacher and so I sadly said goodbye to my longings [to be a therapist]. . . It wasn' $i$ until I was in the women's movement... [that] I started thinking about what 1 really wanted to do and something that kept coming up was being a therapist. . . . It wasn't until I started making decisions about what I wanted to do apart from the cultural and family scripting that I let myself go with what I really wanted.

(Pat)

Within the group of those whose ferinism developed concurrently with their becoming therapists, there were differences in the degree to which the two developinents were intertwined and interrelated or were paralle? and separate. For only one woman did the two seelli totally integrated:

I have a feeling that they happened simultaneously. At the same time I was learning therapy skills, I was also defining feminist consciousness.

(Teri)

This is also the one woman in the sample whose training in therapy skills came in large part from her work experience coupled with irvoivement in radical psychiatry/radical therapy collectives as opposed to more formal degree-oriented or graduate trairing. The others identified their feminism as develuping "paraliei" to their therapy, with the one at times seeming to have no impact on the other and then at one point or at poivits in time becoming more integrated. 
I was a feminist in my own life, but. I wasn't in the way that I did groups. . . . And then about three years ago ... I thought, I want to start integrating nily feminism with ray therapy because I felt like I was a split person. . . It came out of my own need to merge the two. . . [anó] totally on my own. i didn't know anyone else who was doing it at the time.

(Karen)

\section{Time Allecation}

Feminist therapists were asked, "What percentage of your time, in terms of a 40-hour week, do you spend doing therapy?" Nine (of 19) women did therapy fuil-time. The others responded as follows: one at 60 percent time, one at 40 percent time, tinree at 25 percent time, two at 10-15 percent time, and one at under 10 percent of her time.

This question was the most close-ended one in the interview, and its demand for specificity produced severai research problenis. The question was initially designed to reflect a wonlan's level of involvement as a therapist. However, underlying the question were the assumptions that ful1-time work was equatable with full-time conmitment and that full-time work is the same as a 40-hour week. However, some women reported working 60 and 70 hour weeks, holding full-time jobs during the day and involved in their private practice during the evenings, and on weekerids. In arialyzing responses, those women were categorized as "full-time." For one woman, her decision to shift from a five-day week to a three-day week was in part a feminist-based decision, growing out of the permission she now felt to decrease the amount of time she sperit. earning money (and subsequently the amount she spent to live) and to comit more of herself to other parts of her life--including the women's movement ond feminist therapy--that were important to her. Therefore, the 
percentage of her time she spends doing therapy reflects neither her commitment to feminism or the percentage of her income she derives from doing therapy (which is 100 percent.). ${ }^{2}$

Secondly, the question raised early on in the interviewing process was whether to include oniy direct therapy as time sperit "doing therapy." UTtimately, "activities related to your therapy" were included in the tine approximation, on the assumption that full-time therapists engace in reading and study, trairing and supervision, consultation and perhaps personal growth experiences in addition to the direct therapy they do in the course of a 40-hour week. Therefore, the percentages of time spent "doing therapy" include these therapy-related activities as well.

For severai women in the Bay Area interviewed, "therapy-related activities" included what seems to be a newly developing form for training in feminist therapy--peer consultation or case study groups. The groups vary from one with a focus or specifically feminist issues as exemplified by particular cases presented, to one with a radical feministsocialist perspective concerned with integrating feminism and socialism, to one which combines such issues as whether one can be a feminist and relate to men with personal therapy for the group members by others in the group. In all the groups, however, the basic format is similar, with

${ }^{2}$ Acker (1973:179) deals peripherally with this issue in discussing the oversights in sociological research with regard to sex roles. She writes that considering women "as persons rather than as appendages to males" still does not resolve the problem of how to define their sucial status, "particularly if they are not working for pay and cannot be categorized on the basis of their own occupation and income. Can vaiue be assigned to productive work which is not paid labor?" 
a focus on integrating feminism and therapy through meeting on a regular basis in a group of one's peers for study, consultation, input, support and, at times, personal growth.

Finally, an issue developed around what exactiy "therapy" was. Many of the women interviewad were engaged in a wide variety cf activities which colild in the broadest sense be considered therapy: from teaching women's studies to assertive training workshops to boat building. If in the course of answering this question it appeared that a woman's rarge of activities inciuded more than therapy in the traditional sense, site was asked which of those activities she considered to be "therapy" or what she was meaning when she talked about therapy. Her definition of therapy was henceforth accepted during the course of that interview both in terms of calculating a response to this particular question of time allocation, as well as included and probed for in future questions during the interview regarding the nature of her therapy. Therefore, within the sample, the distinctions while internally consistent are externally inconsisterit, in that what one woman included as therapy another may have excluded. However, since the study was based initially on seif-identification as a feminist therapist, it seemed congruent to go one step further and allow for self-definition of those activities labeled as "therapy."

\section{Portraits of Feninist Therapists}

In many ways, the data analysis, focused as it is on themes, on comnonalities and differences, and despite the attempt to utirize quotations iiberally, loses the flavor of the individuals involved. 
Therefore, presented here are briaf descriptions of two of the feminist therapists interviewed, followed by some impressions about the feminist therapists from the interviewing process.

Nancy. I went to Nancy's house for an early morring interview. Somehow I had expected her to be older than I am, but we are both in our late twerties. From her questionnaire, I knew she was an M.S.W. who had done therapy for three years, currently in private practice and working for a private community clinic, focusing on women, specializing in longterm psychotherapy, women's counseling, and ivomen's sexuality training, and listing assartive craining, behaviorism, eclectic, Freudian, Gestalt, humanistic and psychodynamics as theoretical orientations. The two things that impressed me first were that she wore her bathrobe for the interview and had coleus plants on her sunporch that were three feet tall. As the interview progressed, I was impressed by her concern and commitment to honesty. She spoke slowly, thoughtfully, and seriously, deliberating before she answered. My sense was that many of the questions I asked her were ones she had herself been thinking about for some time.

From the beginning, she described herself as a "very conservative breed" of feminist therapist, and often referred to the differences between herself and cther feminist therapists she knows, which become particularly clear for her in combining her private consultation with a psycriatrist with the input of the peer consultation group of which she is a part.

This is one of the interesting things I'm trying to put together... The structure that I work within is something that a lot of feminist therapists wouldn't go nearr, because it is a man that I consult with, and he's not oniy a man--he's an oider man who's a Freudian. . . [ [t is] very stimulating 
and challenging for me to surt cut. I'll go to him with a case that i might want to taik about a certain angle of, and I'll present a different angle of it to my peer group, and then wiat I'm left with no matter how I look at it is trying to integrate what happens with both groups. . . A client of mine I've been seeing for some time has now come full-way around to defining herself as a lesbian. . . In the peer group, we'li talk more about whether we can help somebody at that point or not, and what all the issues might be that there are to be dealt with. Those are the same things that I'1l talk to my Freudian shrink about, but the peer group will be much more sensitive to the issues behind the lesbianism, of what I as her therapist now mean to her, and... giving more credit to the socia? influence. Hy Freudian consultation will get right into the heavies, the transference, and stuff like that. When I go into the next session [with her], I'll be trying to integrate this and coming up with what I realiy do. It's really challenging, and I love it, and I wouldn't have it any other way.

On most issues, she does take a more conservative position. In terms of making connections for a woman between her personal and social experience, she describes herself as "fairly low-key with interpretations" generally and wonders if that has to do with her style as a therapist, as a feminist therapist, or as a feminist.

I personally. . . feel it's real important to help people get. to their own conclusions, and to know the right time to put [out] interpretations, so that I do go easier on that than this other woman [I know] that I think puts out a lot of interpretations to a woman that she's behaving that way because she's a woman, and why. There's a definite extreme of that I don't go near.

She explained that she herself came to feminism very gradualiy. She was a therapist first, and thinks this may explain some of the differences between herseif and other feminist therapists who were feminists first and then decided they wanted to be therapists. When asked what influenced her in becoming a feminist, she said that it was partly her own life experiences, particularly the combination of influence of one woman in 1967 who was a feminist, her divorce, and her decision to go to 
graduate school; and partly it was her exposure to the political activities of other women and wonen's grours around her in the last few years.

At the end of the interview, she wondered whether the questions I had asked seemed to be the ones that most feminist therapisis were asking themseives and struggling with, and then she explained why she had asked:

What I mean by that in personal terms is that it might not sound like it, and then on the other hand it may, [but] I trink. that I've thought about just about all of the things that you've asked about. So my persona? transiation of what I was putting out was, I'm eager to know if there are more isslies and more questions that haven't come to my attention yet, and I' $m$ anxious for those.

My sense is that it did show that she'd thought about these things. In doing the data analysis, I was struck repeatedly by the aivareness she conveys of the issues involved in each position she takes and the integrity with which she maintains a consistency in therapy with her beliefs and values.

Diare. Diane described herself on her questionnaire as having an M.A. in Educational Cognition, having done therapy two years, currently employed by a public agency, focusing on women, and listing eclectic, Gestalt, and Don Juan as theoretical orientations. I interviewed her on the sma1l boat in which she lives, moored in Seattle's ship canal. In keeping with her philosophy of Death and Dying for, as she changed it, Death and Living), which says that you could die tomorrow so you must live as though there is no tomorrow, she decided she wanted to live on a boat, bought one, learned to drive it, and sailed it to the moorage where it is now docked. 
I get most of my philosophy now from Don Juan and this iittle book a friend gave me called Lazy Man's Guide to Enlightenment-it's by living as if there is no tomorrow. For example, if I wanted to buy a boat and 1 had to wait until I had the money for the down payment or until i had a job--it was a very insecure place to move out and buy a boat and yet because I did it, thirgs happened, things took over for me.

Aithough she said, yes, she considered herself a feminist therapist, at first I had a hard time understanding what she did as a feminist therapist--certainly it was like no one else I had interviewed. She said people called her wher they needed her and they would come to the boat, but that she didn't charge tinein. Mostly, she spends her time heiping a neighbor rebuild his boat. As she talked, it became clearer that she would be called a natural helper, someone who functions in a helping capacity, without pay, without ary organization behind them, but to whom people in their network know they can turn. I shared this with her, arid she said:

Sometimes I feel like I'm a walking philosopher. I think I'll probably be a guru in my next life. I feei like I'm always expounding on how I fee] about things [whether I'm building the boat or helping somebody in a more "therapy-like" way]. I'm living feminism. . . and I'm sharing it as I'm living it, not at certain hours, certain days. ... It's going to be a personto-person thing that happens through my friends or when somebody needs me in a moment. I' $m$ not going to take money for it. find a lot of my teaching of my feelings arid my philosophy about feminism is by example. . . I'm a hell of an example to all these people down here [as the first woman]... . This place has changed, I've heard, since I moved down here. Because I' $m$ very much a woman, and yet they sae my rebuild my Volkswagen engirie, they see me take care of my boat. I manage things and I'm still a woman.. I feel like I'm also a teocher to my other women friends or women who meet me, because of that example, because I do live my life very much for me... .

[When I do do "therapy"] the thirgs I ta]k about are very much related to me and how I'n livirg my life. If somebody sees me, they see me down here, so there's congruency. I'm not spieling out a philosophy that i've learned in order to fit their situation. I'n coming from me, and what I feel the strongest. I get 
emotionaliy involved. I don't. stay aloof. I'm not afraid to care about someone and let them know that. I left [Dehind] al? those rigidly defined structures, philosopinies. . . . I'mi going to be doing [my therapy]--street therapy--while I' building boats. . . [But] who knows how long I'i] do noat building. Who knows how long I'll live.

When I asked her if she were a feminist first or a therapist first, she said that she thought she was probably always a feminist.

I've always lived my life according to how I needed to live it and how I. saw what was important to me. I never got married, went through a marriage and subjugated myseif to my husband or my children. Somehow I managed to stay away from relationships that were really cegrading to me. Inside my head, even though I wasn't conscious of it, I was taking care of myself all those years.

However, she became more identified with the feminist movement five years ago when she was working as a legal secretary and began noticing that her boss was very threateried by her inteligence and the fact that she was going to leave the office because being a secretary wasn't satisfying enough for her. She also sat next to an older woman in the office who was active in the women's movement thirty years ago, and out of those two influences she started feeling a rapport with the women in the office, encouraging them to wear pants and to call the attorneys by their first names. After going back to school and getting her Master's in educational psychology ("I thoughi [at first] I'd go into special ed., and as soon as I got into the department I knew I wasn't supposed to be there because they were passing ouc M\&M's. . Which just abhorred me"), she did therapy for a year, followed by a death and dying workshop, after which she increasingly came to reiect the traditional forms of therapy.

I thirk what made it change is i rea?ized I don't grow by going and taiking to somebudy else about when I'm down. I work it out on myself by doing things. Doing things makes me feel better, particulariy if I'm doing them for myself. . . [It's] not growing by complaining to somebody else. 
Overal1 Descriptions of Feminist Therapists. When I let images of the feminist therapists I interviewed move through my mind, what I see are 19 individual women in the midst of our interviews. Al1 were women; most of them were in their late twenties, although six were in their middle years. I interviewed them in their homes and offices (al though sometimes the two were the same). I felt their commitment to what they were doing and the peopie they worked with, and observed, parentheticaliy, that ail but one woman spoke of "clients" rather than "patients." Overall, the thing 1 was struck by was the integrations each woman had made for herself. They disagreed with each other in many areas, but each woman was consistent throughout in terms of her own position. They took the interview seriously, siruggling to answer the questions, to explain what they did and noreover to be helpful to me.

\section{HOW DO FEMINIST THERAPISTS DEFIME FEMIMISM?}

Information comprising this section iriciludes part of the answer to the question, "What do you do with your feminism in therapy" (as Feminist Values), and answers to the interview questions, "How do you define feminism?" (as Definitions of Ferinism) and "How much of a ferlinist does a persun have to be to do feminist therapy?" (as Feminist Criteria). Ini addition, included (as Other Comnents on Feminism) are comments made at varicus points during the interview about the directive pressures exerted on women by feminism, the relevance of fentinism only in this social context, and the relation of ferinism to econonic and political analyses. 
Feininist Values

In answering the question, "What do you do with your feminism in therapy," a number of women began their responses by stating, in essence, "What I do with my feminism in therapy is be a feminist." Often, clienis come to them because they are identified as feminists, expecting them therefore to have certain values and orientations.

I think. . . 90 percent of the people that I see come to me because... in their own minds. . . they define... me as a ferninist or a "woman's 1ibber" or identify me in some sense with a person who believes in women, who believes in women's potential, who believes in non-stereotypic kinds of roles for wonen or at least the opportunity to choose from anong a vast variety of roles and lifestyles.

(Sue)

Feminism is integrated into their own lives, their feelings, their value systems and their way of looking at the world--"it's part of my make-up" (Ann).

I feel like my whole iife is ferninist in some sense. Just the fact that I am a woman. I feel like I confront prejudices agairist women on all kinds of levels all the time, including in myself. (Beth)

To be a feminist "means that you have a certain kind of knowledge" (Alice). With the integration of feminism into their lives is the integration of feminist values into their value systern. "It's hard for me. . . to separate my values [from what I do]. My values are feminist-related, very much so--that's who I am" (Sue). As they do therapy, that feminism may be "triggered" or felt more strongly at some times than others, but it is always present.

They speak of themselves as having "feminist" vallies, which seem to go beyond a narrower definition of values as ethics or morals to encompass a belief system or world-view which a person "buys into," 
acknowledging from the beginning that at a certain point a morai judgment of reaiity is made (Stevens 1971). On the most basic ievel, for them feminist values include:

- - the berief that womer differ from men because of social conditioning on the basis of sex-role stereotypes.

- the belief that that socialization has been destructive and oppressive for vomen, furcher institutionalizirg them into certain restricting and conflictual roles, behaviors, and careers which have hindered their self-actualization, perpetuated their secordary status, and produced emotional distress.

Being a feminist, then, for these women means a belief in women and in their potential. They stress the positiveness of their orientation-they valle women and being a worlan.

I try and focus the basic feelings that go on with anyone-insecurity, anger, sexuality. . .-with their consciousness of their additional status, additionai burden. And i try then, a iittle at a time, to turn it into their additional asset, the sense that to be a woman, to be in touch with all those things, to have had that experience, as debilitating as it was and can be, they can turn to strength. They can turn their anger into power; they can turn their sensitivity into an awareness not only about themseives but about other peopie. (Alice)

Almost ail the women interviewed talked about feminism as embodying a belief that each woman is--or can be--responsible for herself and for her own life, that she does know what she wants and what is best for her. If she is supporter and given the permission to do so, the decisions and choices she makes will come--and reed to come--from that knowledge rather than, as perhaps previously, responses based on stereotyped role modeis of how a woman "ought" to be.

I seem to run into a lot of women who feel like they have to have à man in thair lives... As a feminist I'm asking continualiy, what are they doing to make themselves happy, what does their iife consist of . . . I emphasize more, "What is your life beyond. . . does he love me or does he not love me?" so in a serise i'm defusing that.

(ETlen) 
I just basically view [foninism] as respect for other people, .. not putting people in a 'not OK' position. . . Feminism means right now [to rie] to just be yourself, [to] decide you're OK whether jou fit the role model or not. (Holly)

To a certain extent, they are restating basic humanistic values. However, there is the additional focus on the ways sexual stereotypes have kept people, and especiaily women, from self-actualization, an awareness of and sensitivity to the particular neecs, problems and concerns of women as different from those of men. There is also a vaiuing among these women of the questioning of traditional stereotypes and of moving toward non-stereotypic role models or freedom from all sexual roles. As an example, cne woman described a contract group she ran for women.

A lot of the women came in with a contract that they wanted to feel better about themselves... or to be able to express their anger more. In a way all these things are really related to how vie feel about ourseives as women and how we're scripted to not be ourselves and to take care of everybody else... . [Aithough] the contracts were not specificaliy, "I want to know more about myself as a woman," in the process of working on those things, they've tecome more liberated. One woman I can think of started out in a very submissive, docile [piace], and was in a marriage that she didn't want but wasn't ready to do anything about. . . She's now separated from her husband, has a lover (which she's gotten lots of strokes for, lots of permission to have) and is just like a completely different person.

(Peg)

Definitions of Feminism

Definitions of feminism were arranged within a four-square grid and sorted 1) according to whether the definition (or component of a definition ${ }^{3}$ ) focused on human comnonaities ard human potentiais,

$3_{A}$ rumber of definitions contained several components. In order to preserve the complexity of the response, definitions were separated into component urits and each component was listed separately. Thus, it is possible for one respondent to have more than one response in a category, and/or responses scattered among several categories. 
classified as egalitarian, or on women and/or differences between people based on sex roles and sexial oppression, classified as sexual differentiation; and 2) according to whether the definition (or component of a definition) dealt with beliefs (values, attitudes, consciousnesses, awarenesses, perspectives) or processes (actions, struggles, movements).

Whether the definitions are counted as single units or combined within squares by respondent, the order of frequency of categories listed remains the same. Definitions involving beliefs in sexuāl differentiation are listed most frequently, followed by processes of sexual differentiation, egalitarian beliefs, and egalitarian processes, in that order. Because this was part of the final question of the interview, most responses are short, terse and unexpilicated, and Figure I shows the definitions of feminism sorted according to the above systein in their totaity. Table XI shows the number of responses in each category.

TABLE XI

CATEGORIES OF DEFINITIONS OF FEMINIST THERAPY

\begin{tabular}{lcc}
\hline Category & $\begin{array}{l}\text { Total number of } \\
\text { definitions in } \\
\text { category }\end{array}$ & $\begin{array}{l}\text { Total number of } \\
\text { individuals listing } \\
\text { cne or more defini- } \\
\text { tions in category }\end{array}$ \\
\hline Sexually differentiated beiliefs & 17 & 9 \\
Sexually differentiated processes & 12 & 7 \\
Egalitarian beliefs & 7 & 5 \\
Egaitarian processes & 4 & 4 \\
\hline
\end{tabular}

Eight more definitions based on beliefs are listed than definitions based on processes, seeming to indicate an emphasis on feminism as a belief 
FIGURE 1

\section{DEFINITIONS OF FEMINISM}

\begin{tabular}{|c|c|c|}
\hline & EGALITARIAN & SEXEA PIFFEREHTIATYOH \\
\hline 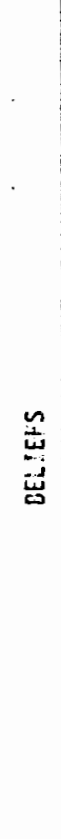 & 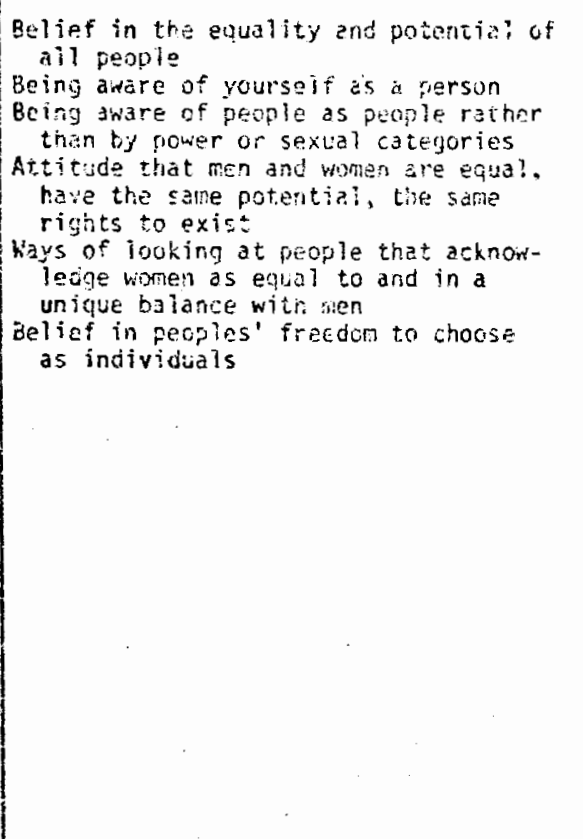 & 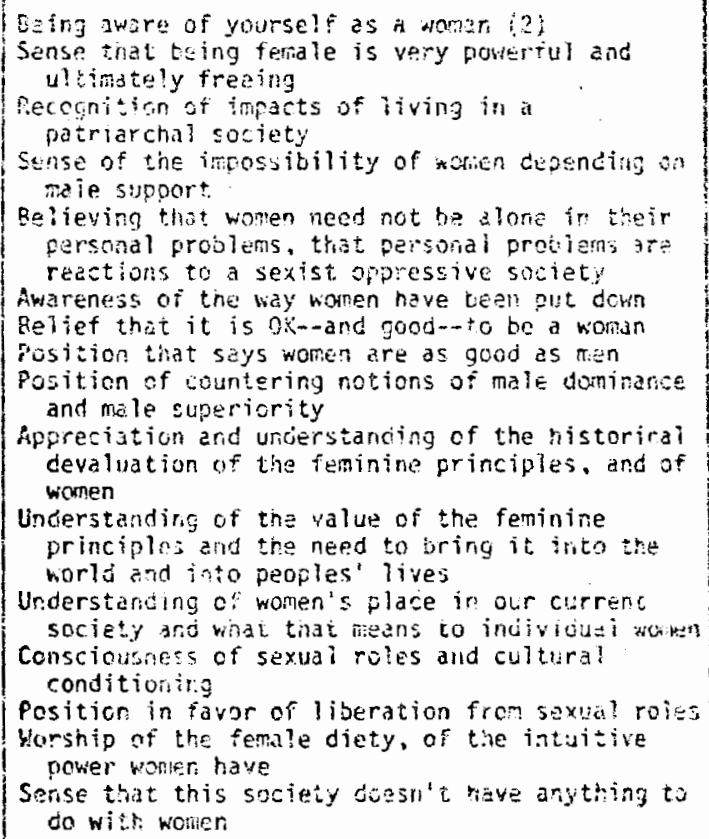 \\
\hline 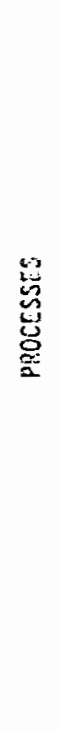 & 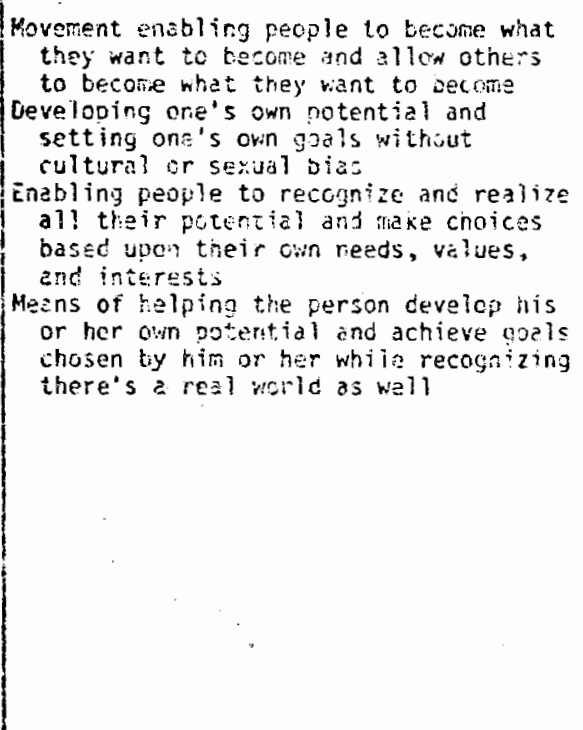 & 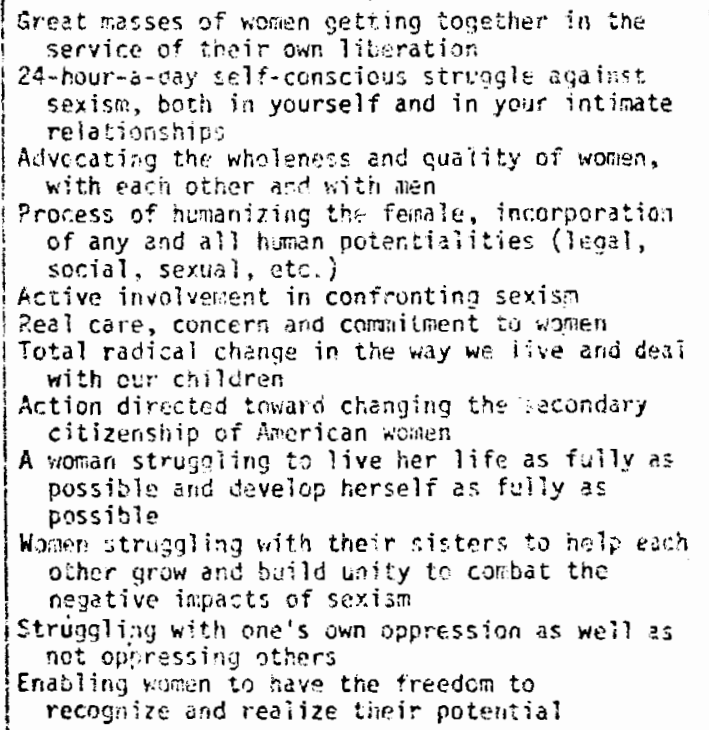 \\
\hline
\end{tabular}


system. Twenty-nine definitions involving sexual differentiations are listed, as compared to 11 definitions involving egalitarian sexua? commonalities, a strong indication of feminism's focus on women as a separate group and on differences between people based on sexual roles and sex role oppression.

\section{Feminist Criteria}

Interviewees were asked, "How much of a feminist does a person have to be to do feminist therapy?" In essence, they were asked to indicate what criteria they would use in deciding if a person who said she or he was a feminist therapist were one or, in other words, whether there were certain behaviors or degrees of feminism they feit would necessarily have to be preserit for a person to be a feminist therapist (or a feminist) and whether there were certain behaviors which would exclude a person. The question intentionally spoke of a "person" rather than "a woman" so that men could be included or excluded in an iriterviewee's response (probed for specifically in Section III, Men as Feminist Therapists).

There vas great diversity and variation among what these feminist therapists thought were the basic criteria necessary to be a feminist therapist. For purposes of presentation and discussion, a four-square grid was developed which enatied the sorting of responses as follows: 1) low-demand/high-demand: to what degree incorporating the behavior demanded risk, sacrifice, life-style modification, or basic and significant changes in feelings and attitudes; and 2) inclusive/exclusive: whether the behavior as described in response to this question had to do 
specificaliy with feninism or sexism as differentiated from therapy per se. In each case, the response presented is the behavior (or one of the behaviors) one or more feminist therapists said they thought had to be present in order for them to consider a person to se a feminist therapist. Figure II shows the behaviors indicated differertiated by categories, with numbers following each behavior showing how many feminist therapists listed this behavior as a criteria for being a feminist therapist. As Figure II illustrates, the greatest number of therapists listed resporises which were high-demand exclusive.

This would seem to indicate that most feminist therapists see the criteria for being a feminist therapist as i) placing high demands on the person, and 2) having to do with feminism. However, the number of high-demand exciusive responses are closely followed by the low-demand inclusive responses. Since there were no respondents with replies in both of these two categories, this may indicate a division between those who see the criteria for being a feminist therapist as those any good therapist would be expected to have and those who see the criteria for being a feminist therapist as those orily feminists would have and moreover those which place high demands on the feminists theniselves. It is interesting to compare the number of responses under each heading. Nineteen behaviors 7 isted (seven inclusive and 12 exclusive) were lateled high-demand as compared to 13 behaviors (nine inclusive and four exclusive) listed as low-demand, seeming to indicate that feminist therapists see being a feminist therapist as highly demanding of the person herself, implying risk, sdcrifice, life-style modification and/or basic and significant changes in feelings and attitudes. Interestingly, 
FIGURE II

CRITERIA FOR DOING FEMINIST THERAPY

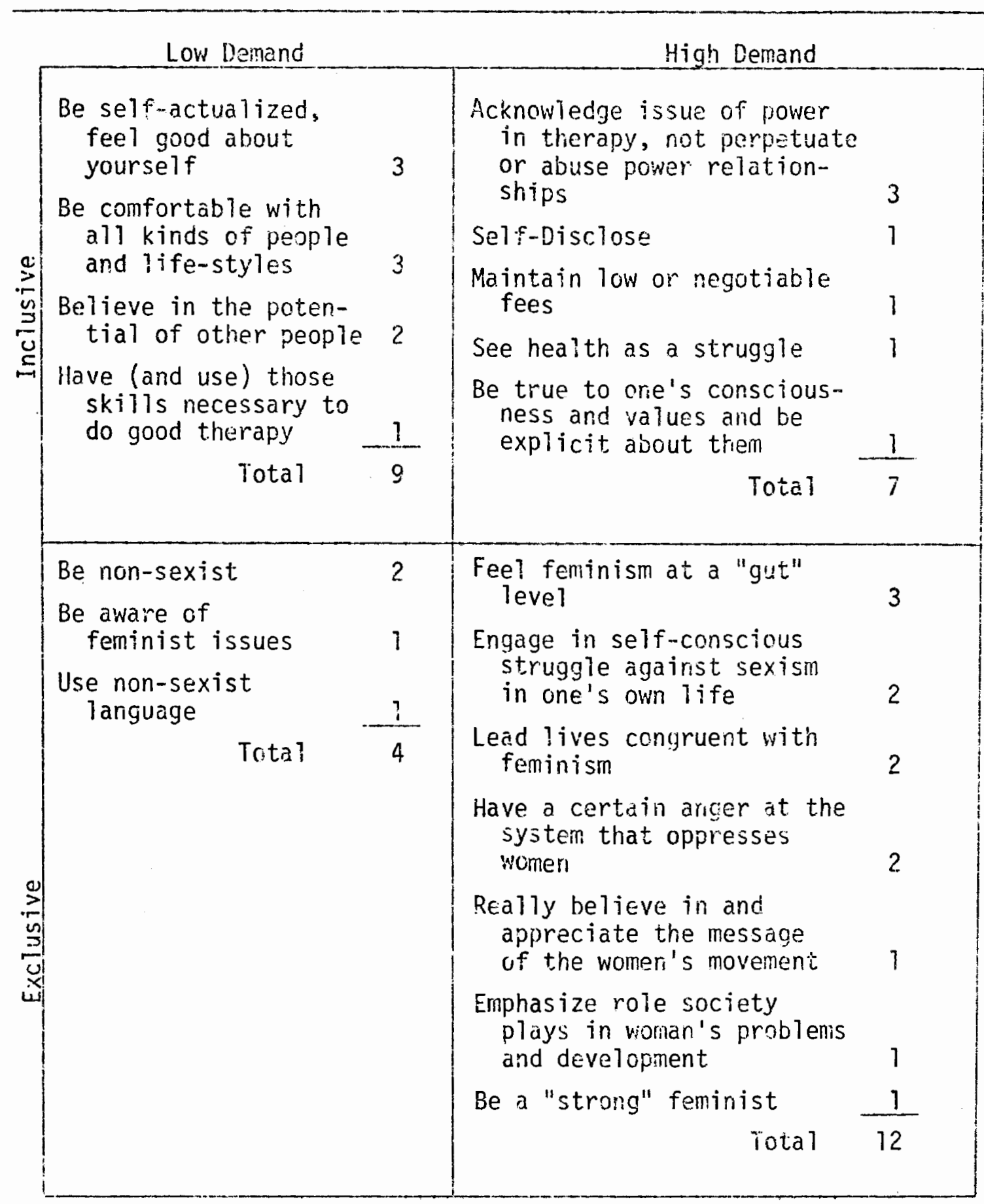


16 responses were inclusive and 16 were exciusive, seeming to indicate that of those behaviors deemed necessary to be a feminist therapist, those winich do not have specifically to do with feminism are as important as those which demand a feminist conscicusness per se. This may indicate either the belief that the criteria for being a feminist therapisi goes beyond what is typically considered a "ferninist consciousriess" to include changes in other therapeutic behaviors as well or trat feminist therapy is not something only a feminist can do. Both positions are represented among respondents.

Some feminist therapists are concerned because they feel that being a feminist does not mean a woman necessarily does good therapy, while some feel that a number of women are caliing themselves feminist therapists who are not really "feminist enough." in other words, some see feminist therapists who have jumped on the "therapy bandwagon," thinking they can do therapy just because they're feninists, while others see therapists who have jumped on the "feminism bandwagon," thinking they are feminist therapists just because they're women. Seventy-five percent of those who talked abcut a "therapy bandvagon" had replies in the low-demand category, while ali of those who taiked about a "feminist bandwagon" listed criteria for being a feminist therapist that were high demand.

The low-demand inclusive response of feeling good about yourself or "having your own head together," and having the necessary skills to do good therapy were 1 isted by three feminist therapists prefatory to an explanation that some feminists could not do good feminist therapy because of their anger, the need to "put clown" others not in agreement 
with themselves, and an inability to be open to and accepting of all people.

1 think that there are probabiy a lot of feminists who can't do feminist therapy very we!1 . . . for one reason or another, because of aggressiveness, because of lack of patience, because of an inability to reiate to somebody else's experiences in a way that enables them to grow and not utilize [the therapy] for one's own personal needs to be on a bandwagon. . . Too much lecturing is not therapy.

(Sue)

These feminist therapists were critica; of other feminist therapists who they perceive to be imposing their values on their clients, telling theri what they must believe.

One of the problems with a lot of feminists is that they feel they know better than a lot of women about what's best for the woman. And that's [just] pushing another piarty line.... It's not Frelid, but it's Marx, or Mao Tse Tung or . . feminisn.. And the woman doesn't have a choice. She's put down if she doesn't stand up for herself or get a job or.. . if she waits for her man. She may wart to wait for her man. A1! I'm interested in is that she knows that she's doing that and that she feels OK. about that. (Leslie and Carol)

They are saying that no matter how much of a feminist a woman may be, if she has not done her own personal work, resolved her own personal conflicts, she cannot be a good therapist and a good feminist therapist.

A lot of women are involved in the movement who feel dissatisfied in themselves and so they've put a lot of negative energy out by putting other people and things down in order to make themselves right. It's like, if you want to move from point $A$ to $B$, if $A$ was, "I was married and I have three kids and I ccoked for my husband all my life" and all of a sudden I decided to change [to move to point BJ, so I called him a schmuck and the kids a burden to me and ariybody who is [stili] in that role a creep, just for me to move. There was so much negative energy in the women's movement that I rad to get away from it because I find it sickening. . . In order to help somebody, in any sense, you have to feel good about where you're at, [and not be] struggling to get to a certain place and therefore. . have to put a lot of other places down in order to get there. . . They're a lot of feminists that I would say could not give very good therapy. . . Their focus is so limited and so angry--they miss the whole rest of the world.

(Diane) 
On the other hand, some feminist therapists criticized women who had not had any "gut experiences" with feminism or did not live in accordance with ieminist values but had read a few articles and were sympathetic with the women's movement and thought therefore that they were feminist therapists while still continuing to do things--like charge high fees--that were in contradiction with feminism.

There are some people who call themselves feminist therapists, who say they do feiminist therapy, who 1 feel are being deceptive. - . Part of me feels that at least if you call yourself a traditional therapist, then [clients] know what [they're] getting in for. But I think a lot of people who say they're feminist therapists and who I know are not are kind of getting on the bandwagon. It makes me furious. (Karen)

This theme was repeated through most of the high-demand exclusive responses. Three therapists said that for a woman to be a femirist therapist, she would have to have had a "gut" experience with feminism.

For me, feminist consciousness is like picking my head up and turning it ali the way around and seiting it back down again. People who haven't gone through that experience can miss a whole lot and end up looking at the world in what I consider now a very outdated way, corning onto men in the groups in an old female stereotyped pattern, missing issues that women are dealing with because they don't yet exist with emphasis [for them]. I don't like rote therapy, people doing a number because they've seen it done... or read about it in a book, and it doesn' $t$ come from the gut. For anyone to deal with femirist issues who hasn't had a gut experience with it seems like rote therapy to me.

These women stressed the importance of a very deep, almost shocking experience in coming to awareness of feminism, and felt that those who had not experienced this could not reaily be feminist therapists. One wornan said, "It takes some kind of 'leap' experience with it yourself, some kind of shock experience, when suddenly I see what I haven't been aware of before." She went on to explain that she felt many women 
therapists who had read an articie or two ard subscribed to Ms. Magazine called thenselves feminist therapists but were not really that at all and were merely

. . leaning on the fact that they're wonen and . . . think that gives them a certain amount of feminism simply because they are women. But I think it takes more than being a woman. It takes more than having read a few articles. It takes more than having sone sympathy or identification with the movement.

(Leslie)

As contrasted with those three therapists who under low-demand inclusive said a feminist therapist needed to be self-actualized, two therapists in this category focused on the process of struggle towards that, believing that the important thing was not to achieve "mentai health". which was impossible, but to be self-consciously struggling toward it in one's own life. Two therapists said that it was critical for a feminist therapist to lead her life in congruence with feminism.

I would imagine to really see feminism as part of your life, something that you think about and is part of you, to have gotten that so much inside you that it's just part of you, that you wouid have to be pretty feminist. . . If it weren't part of your life, I think it viould be impossible for you to be any kind of feminist therapist.

(Ann)

Two other therapists felt a feminist therapist needed to have "a certain anger at the system" (Ellen) that oppresses women. They disagreed with those who, in TA terms, viewed anger as a contamination of the adult ego state and therefore always saw feminisan as in part pathologicai.

The oppression is real. It's out there. The anger is important. Anger has a definite piace in the vorld and I don't think it should all be spent in therapy, worked through. I think it's a heaithy reaction that women especially feel. What's important is what they do with the anger.

(Holly)

One woman said that a feminist therapist needed to be "a very strong feminist." She continued: 
As Ti-Grace Atkinson said, "In the ultimate sense, it's who you die with." And I would die with women. That's where my loyalties are. If you spend two-thirds of your energy with men and call yourself a feminist, I find that questionable. . . She used to say, "It's like fighting the Germans from $S$ to 5 and going to bed with them at night." That does not make sense to me, and the analogy holds [for men]. So jt's a struggle a lot. of women are going through, and a lot of women have to make some choices about that.

(Marsha)

As would be expected, there were a certain number of qualifications to the question itself. One therapist said that it was a question she just couldn't answer because her definition of what a feminist therapist was had "room for all kinds, all gradations on a scale." If a woman called herself a feminist therapist, then this therapist would not have any reason to question that. In fact, "If she said that, I think I'd be prejudiced in her favor, frankly" (Alice). She and another therapist both indicated that "how much of a feminist" a therapist needed to be depended on what the individual client wanted, "and there are ali kinds of clients."

There are people for whon I would be too much [of a feminist]. There are others for whom I'm not enough, 'cause I don't march, because I do my thing in a relativeiy' small-scale private way, and they believe that larger, more vocal action, more observabie action is what it takes to be a feminist. Their definition varies with mine. And they cali one "more" than the other. I don't see it that way. I don't krow how to quantify it. (Alice)

Another therapist also commented on this difficulty in quantifying feminist therapists, saying, "How mucr--is that like being part pregnant?" (Sue). Four women expressed a concern that the question fed into establishing a judgmental hierarchy of feminism, that it was "a set-up to play "more feminist than thou'" (Teri). They wanted to focus on the commonalities, not the differences, among women. 
I don't want to get into the thing of putting women down. A lot of people do call thenselves feminist therapists and they're not as political as others. We just have to struggle. They're doing a thousand tinies beiter, I think, than any male, in dealing with women.

(Marsha)

One said that in order to answer the question, she would have to determine the context in which it might even be relevant.

I know that there are women and men who cali themselves feminists and practice feminist therapy who I don't agree with about some stuff, who I think are not doing the self-conscious struggle in their own lives, perhaps. I think there are some professional women therapists who are Queen Bees. So they're still called feminists, but it seems like they're a lot of contradictions in the ir own personal practice. My tendency is not be a "lefter than thou player," though, a "more feminist than thou" player. It depends [again] on why that question would be recessary. When it came to a direct referral, would I refer someone to somebody who I thirk isn't doing good? No. If I nave a sense that somebody is rot going to be as good for someone as someone else, then I'm not going to send them. Would I work with somebody who cails themselves feminist but I feel is very individualistic and bourgeois? Yeah, I work with women whose political goa is I don't agree with.

(Teri)

She concluded by saying that even though there are some feminist therapists she knows whose political positions she disagrees with, they are still going to be better than most male therapists, "no matter how radical his politics and no matter how much he avows his feminist position" (Teri).

Finally, four feminist therapists discussed in their answers criteria they could imagine for what a feminist therapist had to do which would exclude them; and for all four, that criteria had to do with active (or "heavy") political involvement since they described their own involvement as tangential or mininial. In answering, one therapist struggled to decide if she would consider herself a feminist therapist, and ultimately decided that being true to one's politics--whether they 
be personal or social-.-was for her the crucial criteria for being a

feminist therapist and therefore that she was a feminist therapist.

I have in my head. . a couple continuums along which it's possible to define feminist therapy. I can see how it's possible to say. . . that unless someone is politicaliy active (that is, involved in some group, sone kinds of educative efforts or some kind of political setting up of alternative structures or fighting against existing structures...) and then carrying that politics directly and explicitly into their therapy, then one would not be defined as a feminist therapist.

Well, I fit into that category with some people I work with, so I could say I'm a feminist therapist with some people.. . who . . want that. But. . one could be a purist and say if I don't [do so] all the time then I'm not and [then I would be] on the further [outside] end of that continuuin.

On the other hand, I could say that where I'm at is trying to be trie to my consciousness and my values and beliefs with whomever I'm working whether or not political issues.. become explicit. Maybe I'm hiding and pretencing [in saying that] because then I'm not assuring a political position really--but yes I ám. I'm assuming a position in terms of personai politics [aithough] I may not be assuming a position in terms of social poitics. . . . So if you get way down to that end of the continuum you could say . . . I continue to be a feminist therapist in the sense that I'm true to my consciousness and I operate. . . in a way that's compatible with that.

(Joyce)

\section{Other Comments on Feminism}

In the context of other responses, 11 women at various points in their interviews discussed tine directive pressures exerted on women by other feminisis (and by feminist therapists, discussed above). They speak of their sense of the jldgmentai aspects of feminism--"putting people in a 'not OK' position" (HoTiy).

Ore thing I feei really strongly about is I don't wart to be a part of a movement that creates another stereotype in the process of wiping out one stereotyne. I don't think there should be a stereocype of the "liberated woman," the feminist. [I don't think there should be] a right way to be for wonen which says the right way to be is to hove a career. I think there are too many people who perceive thet, but it realiy is CK to be a mother, a wife... if it's a choice. (Sue) 
Sornetimes, these therapists say, they see ciients who have incorporated the feminist value system into themselves, and use it as a standard to measure themse?ves against. One woman explains that feminism hâs been so demanding in its insistence on conformity to an ideal that it leaves women unable to acknowledge publicly when they do not "measure up" to that ideal. Another therapist described how women "top dog" themseives, being highly critical of those things they do which may be "unfeminist." This is an issue for her as well as for her clients. She explains that her tendency is to be judgmental, set arbitrary criteria, and take the most radical position, and that she is struggling to feel more compassion for herself.

Ore of the things that I'm coming to accept is that we're all struggling, that it's not perfect, that there are a lot of contradictions ... I think it's important to struggle with it but I've teen more easy on myself. . . . Having to be the most radica? is what i'm struggling with now. A lot of ty ranny that a lot of women have experienced, including myself, is being afraid to open our mouths beralise we won't be saying the most radical thing... I've used dogma on mysalf, saying, "You're not really a feminist therapist." One of the things that I've been seeing in getting together with other women is that it's a new area, that things aren't set hard and fast--it's something that's being tested and developed.

(Karen)

Another therapist reported asking a married woman, in an intentionaliy non-expressive, non-judgmental way, if she were still doing the cooking, an issue the client had discussed with her previously. The ciient "iristled," hearing the therapist's question as coming from a feminist perspective, according to which, by cooking, she was "not OK" (Nancy).

Several therapists said that while the women's movement has been important in their own lives, they see it as demanding that women be always hard and strong. Ore therapist feels that at times feminism is 
- counterproductive for some women when its focus is really anti-ferninine. . . . The women's movement has focused on getting women in and being aggressive rather than on bringing our historically present gentleness and teriderness irito the social process. A lot of people who call thenselves feminists I think are... female chauvinists. I think they're sexists, or racists, or whatever you call that--hating men and also supportingmale values, or what are male values to me.

(Beth)

In a similar vein, one therapist felt that the women's movement uncriticaily claimed that "anything that is female is superior or wonderful, and I don't agree with that" (Teri). A therapist who had been very active previously in the vomen's novement explained that she has rejected the idea of the movement that "what you do is get your consciousness raised and then you go around help, help, helping other women." She does not see women as the "helpless, hopeless cases" that some feminists portray them as, "a disasier area" to which those who have been "en? ightened" need to spread the word (Pat).

Two therapists said that for them, feminism was a position that they hoped would ultimately be unnecessary. They explained that while feminism was certainly necessary and relevant in the current social context, their goal was to make it irrelevarit.

I think it's an antithesis position. We started with masculinism. Feminism is a position taken to counter masculinism. It's not yet synthesis. It's better than non-feminism but it isn't yet where I want us ail to be. I see it as a position of countering rotions of male dominance, male superiority. It's for me sometimes an assertion of bringing women up to the norm; sometimes it's ar assertion that women are higher than the norm; sometimies it's just a stand off--"We're equal, damit!!" $\mathrm{All}$ of which is a lot of energy involved in the countering. It's an annoyarice... that part of what has to happen in these times right now is that in order to respect liyself 1 take this position calied feminism which I hope sonieday is going to be outdated. (Pat)

Five women discussed the relation of political and economic change to feminism. Three felt that feminism needed to be combined with 
socialism or anti-capitalism, a perspective they see often lacking among feminists.

One of the tendencies of the women's movement is to "trench of fl $^{\prime \prime}$ and [say] anti-capitalism [is not the issue]. A lot of women think that all the trouble is with men. . . I think that while there still might be sexism in a socialist context, it will be easier to combat sexism in a socialist context. . I think capitalism needs sexism in order to survive. Capitalism needs inen to breed, to perforin like robots on assemply lines: to go home and rip off their ladies for nurturing and keep producing with their ladies nore workers for the assembly lines.

(Teri)

However, they did not feel that if a woman did not deal with these issues, she was not a feminist. One therapist, however, disagreed. She berieved that feminism can come out of any poitical structure.

I'm not crazy about ours, or anything, but I'm rot as strong a socialist as some of the people I know... [It's like] saying that you can't be a feminist lin?ess you're a lesbian. I really can't agree with that; and I can't agree that you can't be a feminist without being a socialist, or ony other kind of restriction.

(Nancy)

A fifth therapist said she "went around in circles" with this issue, trying to decide whether the particular oppression women face which leads to their emotional breakdowns, disturbances, depressions, masochism and self-destructiveness comes from men as the oppressors or from "the fact that this is a destructive world" (Marsha).

Finaliy, in response to the question about what the issues were for them in combining feminism and therapy, one woman said that she felt a real lack of alternative models of how to be a woman (Holly). Another woman has been struggling with the issue of whether she as a feminist can be in a relationship with a man. "it's a question I think all of us feel at some point or another-..can you stinl call yourself a feminist and be struggling with a man?" (Karen). 


\section{WHAT IS FEMINIST THERAPY?}

This area for data collection was the broadest, most open-ended, and consequently, most difficult to synthesize. Questions asked required descriptions of relatively amorphous concepts and behaviors difficult for any therapist to specify (Burton 1972). This difficulty is reflected in the qualifications given to many of the questions (as Qualifications About Feninist Therapy). The interview questions asking, "What do you do with your feminism in therapy?" and "What do you think a person gets from you that she wouidn't get from someone who wasn't a feminist therapist?" as well as examples of using feminism in therapy and "feminist techniques" 4 are combined here as Descriptions of Feminist Therapy. Responses to the presentation of two polarized definitions of feminist therapy are included as Continuums of Feminist Therapy, followed by a sumnation of the definitions given in answering the question, "How do you define feminist therapy?" A fina? section sumarizes the question, "Can a man be a feminist therapist?"

\section{Qualifications About Feminist Therapy}

Qualifications About the Role of Feminism in Therapy. For mosi

feminist therapists, their developing feminist consciousness has had

4 Generally in response to these questions, the probes for a "good example" of using feminism in therapy and for "feminist techniques" were spontaneously answered. When asked as probes, they were framed as follows: "Can you give me an example of a time when you felt good about how you lised your feminism in therapy?" and "Are there any techniques or modifications on techniques (i.e., Gestalt techniques) that you've made to better incorporate your feminism into your therapy or techniques that you find you lise more frequentily because of your. feminism?" 
more than an inconsequentiai impact on their therapy, and in turn their therapy has increased their awareness. Two women spoke specifically of their feminism as developing as their therapy skills develop and as their practice brings them more into contact with women and the probiems thej face.

As I am a therapist, I am more of a feminist. I was a feminist first, but my inclinations in that direction seem to be more sc, the longer I have done the work. I'm just much more tuned into what's going on in terms of the problems [wonen face], so none of it souncis like words to me, where a lot of it did [before]. (Eîen)

However, at various points in the interview, nine feminist therapists qualified the impact feminism has on their therapy. One therapist said that her therapy has not chianged significantly since she has become a feminist. "My sense of $i t$ is that I would probably do essentially the same therapy regardless of whether there was a current feminist consciousness" (Betsy). One woman questioned whether feminist therapy really exists, since there is not even a psychology of women yet, let alone a whole approach to dealing with women. She explains that a feminist therapist could be a person who counsels feminists, a feminist who does therapy, or a person who does a special kind of therapy called feminist therapy. In her own work, feminism has become less centrai in her therapy as she has received more training as a therapist, so that now she finds herself doing "feininist therapy" less for any political reasons than because she likes working with women.

I became a feminist first, and I thought that I would be able to do good therapy because I was a feminist. I have my Ph.D. in Clinical Psychology, but I didn't really have much training in therapy. When I started doing therapy as a feminist therapist, I discovered that a lot of the things that I was doing facilitated Victim positions. We would sit around playirg 
"Ain't It Avfu?." It is awful, patriarchy is fucked; but to sit around and feel powerless and blame it on men and miale structures was something that was going on a lot... . it wasn't until I started learning more about $T A$ and Gestalt and found a framework that i fe?t confortable in that I developed my good skills.

(Holly)

Several qualified their remarks by saying that they weren't sure that the things they did differently than other therapists had to do with themselves as feminists, as women therapists, or because "I'm me and not somebody else" (Pat). Several thought that what someone would get from them was very similar to what they would get from any good (woman, one said) therapist. They did not consider self-identification as a feminist a necessary criteria for being a feminist therapist.

I have a feeling there are some women who do feminist therapy who don't call themselves feminists. . . . There's one person [I know] whose whole life-style and everything she does... is feminist, but all she connects with the iberation movement is bra-burning.

(Sal1y)

On the other hand, other feminist therapists felt very strongly that "Feminist therapy carnot be done by someone who is not a feminist" (Teri). At the same time, this therapist also questioned whether to label tinings that she did--.like self-sharing and fostering cocperation in her groups--feminist or not. She worders, for exaniple, whether she fosters a spirit of cooperation between people because women generally behave more cooperatively than men for feminist reasons or because as victims of master-slave reiationships, they have learned to cocperate with their masters in order to survive (Teri). One woman said that while feminism was always present for her when she did therapy and that its absence in a therapist would be a terrible lack, feminism was not by itself an adequate approach to psychology as a whole, and did rot by any means "sum up the whole of ne at anl" (Beth). Two women found it nard to 
ansiver these questions because, as one said, "I don't think about feminist therapy every day of my iife. It's like I do it because I do it, because I believe in that" (Sue).

Four therapists said that ihe degree to which they utilized feminism in their therapy depended on where their clients were at in terms of feminism. One woman who saw mostly women "heading in a feminist direction anyway" didn't see any need for her therapy to "put them on the track" (Betsy). Those who worked in a public agency fe?t a primary responsibility to respond to what their clients wanted and not to respond out of their political position if that were not wanted.

[What I do with my feminism in therapy] is very nuch determined by the kind of person I am working with. I identify myself immediately as a feminist,... [but] there are people who come to me who really don't understand the label, who couldn't care less--it's not an issue in their lives. Survival matters to them. Their awareness isn't in a place where they need or want to hear from me on that issue. It wouldn' $t$ be appropriate. It would simply be intruding into their space. which oftentimes is very fragile. But those who have found me through directories or by referral from other women generally know that I am a ferminist [and want me to te a feminist]. (Alice)

In response to the question about techniques, most of the feminist therapists did describe ore or two specific techniques they used to incorporate feminism into their therapy. Ten also qualified their responses to the question by saying, in essence, that they did not see changes in technique as being as central to feminist therapy as changes in values. Basically, they are saying that any technique changes they may make come out of a larger shift in the whole point of view from which they now do therapy. One woman differentiated between deveioping techniques which incorporate femirism into therapy and developing a whoie new orientation toward therapy. Her collective has done the 
latter, calling it a "socio-therapy" (Marsha).

Qualifications About the Nature of Therapy. In describing the percentage of time they spend doing therapy, a number of differing distinctions were made about what constituted therapy. Sone definitions were broad, including not mere?y structured therapist-client situations but other situations which feminist therapists feel have therapeutic impacts. For a Dean of Women Students, this includes career counseling with older women returning to school, teaching, advising and training. She includes the career counseling because "we always get into the whole area and issue of stereotypic kinds of roles and how their lives progressed and how they are now at the point of looking at themselves and their lives very differently." The classes she teaches are onity open to women, and again, the issues of how women have been socialized reoccur continualiy.

I considei in.. . those classes the focus being furthering one's cwr personal potential, and dealing with what you have to deal with right now, as a woman. . . And i consider trat therapy, in terms of facilitating what happens in a group of women who are discovering some new things about themselves and their lives.

(Sue)

Similarly, the advising and training of women leaders of Associated Women Students she labels "educational growth-producing experiences" and considers therapiy as well because as she works with them, she is also talking to them about their lives, feelings, and goals. Ancther therapist explained that her therapy was not merely limiled to the act of therapy, but included as well situations (such as rer participation in two radical therapy collectives) in which she expects of herself the same performance as when she does therapy, ard her personal life, in which she consciousiy utitizes her problem-solving and 
therapeutic skills in her personal relationships and is willing to be called on by her friends for "therapy" (Terj).

0ther women defined therapy for themselves more narrowly. Aithough they saw themselves doing other things in their work which were feminist and/or therapy-related, they did not consider them therapy. One woman, for example, distinguished between the assertiveness training she does and the therapy she does, referring to the former as one of many possible therapeutic/educational experiences a person might have, but which are still distinct from therapy. In part, the difference for her rests on the degree to which professional standards and ethics, such as not advertising for doing therapy, are adhered to (Atice). Another woman distinguished between what she does as a feminist and what she does as a psychotherapist. since she considers her primary identification to be feminist, she functions as a feminist "reaily 100 percent of the time." However, she defines psychotherapy itself as "dealing more directly. . ., dealing more with the casualties [of the system]" (Marsha); and she is not always in that role. A woman who is the director of a drop-in center says that one of the things she does is model a new consciousness about women, "a new way for women to be in the world," which is an extension of--but not directly-.feminist therapy. However, while she does not inciude her administrative functions as part of the therapy she did in calculating the percentage of her time she spends doing therapy, she did include the time she spends training the staff, . . because one of the things that we talk about [in staff training] is self-assertion for the women who work here, and 
gentleness and compassion for the men who work here--how to break out of cultural patterns in relating to people.

\section{Descriptions of Feminist Therapy}

Highly similar responses were received to the two questions, "What do you do with your feminism in therapy?" and "What do you think a person get's from you that she wouldn't from someone who wasn't a feminist therapist?" 5 aithough the former was designed to elicit behavioral descriptions of feminist therapy and the latter broader generalizations about the differences between feminist therapy and other therapists (i.e., the critical aspects of feminist therapy). Basically, they seem to be saying, "I an a feminist. Out of my feminism comes for me certain values, beliefs, ideas and ways of perceiving and acting which I integrate into, build on, and utilize in the therapy I do." As discussed in Section II, the essence of the feminist value system as described by feminist therapists is two-fold: a belief in the potential of women (called Feminist Humanism) and an awareness of how women's potential has been thwarted by sex roles (called Feminist Consciousness). Out of their Feminist Humanism and their Femirist Consciousness come those things which make up ferninist therapy, and differentiate it from other therapies. For purposes of discussion, the components of feminist therapy as described by feminist therapists were synthesized, and are described below. The number following each itom indicates how many of those 19 feminist therapists

50 ther question responses in which comparisons were made betiveen themselves and ron-feminist tierapists are included in this latter question as well. 
interviewed described behaviors fanting into each category. Some replies overlapper categories, and ara included in more than one.

Feminist Humanism .............. 16

Believing in freedom from any mode is or roles-particularly sexual--of how a person (and especialiy a wornan) ought to be

Giving women perinission and support to act in ways prohibited by traditiona? sex roie stereotypes

Modeling a positive inage of a woman and of feminism

Feminist Consciousness ............ . 16

Having a greater awareness and understanding of women and women's problems due to sex roles and sexual oppression

Analyzing problems people bring to therapy from a world-view which has incorporated a feminist consciousness

Having an awareness of societal infruerices on women as well as the individual dynamics of their problems

Changes in the Traditional Therapy Relationship.... 16

Making changes in the role of the therapist

Being concerned with poiver issues and attempting to move toward equality or mituality

Allowing oneself to become more involved, more of an ally (more contact, less distance)

Sharing one's values and experiences (selfdisclosure, attempting to demystify oneself)

Stressing action as well as introspection

Discouraging lengthy therapy and dependency on therapy

Maintäining reasonable fees

Raising Consciousness . . . . . . . . . . . 10

Bringing to a woman's awareness the existonce of sex-role stereotypes and sexual oppression

Bringing into the therapy the societial influences on individual women

Confronting sexism in clients, peers, and other professionals 
Emphasis on the Comonality of Women . . . . . . . 9

Giving a woman a sense of her unity and commonality with other women

Supporting women sharing with each other, learring from each other

Breaking down the isolation women feel toward each other and the mistrust they feei for each other

Responses in each section and methods of implementation are discussed below.

Feminist Humanism. Out of Feminist Humanism, the belief in the potential of women and in the knowiedge of each woman of what she wants and what is best for her, comes a desire to free women of roles which have prohibited the actualization of that potential. Feminist therapisis feel a major difference between themselves and non-feminist therapists has to do with their way of looking at women and men and at their potentials. Feminist therapists see this difference in perspective centering around their depth and degree of conmitment to freedom from sex-role stereotypes, equality between the sexes, and a person's (often, especially a woman's) self-actualization without restrictions from or the determinism of sexual (or any other) roles. They feel that. non-feminist therapists still carry with them certain stereotypes and values--often based on sexual differences--about what are appropriate behaviors, life-styles, interests, directions for growth and change, and roles, and that their acceptance of a wide range of options in these areas from life style to politics to role choices is what differentiates them.

For example, a feminist therapist trained in Transactional Analys is does not accept it when others ascribe the injunction, "Don't Be a Woman," to someone. 
I get confused and angry when I hear that. . . because I don't know if the corollary is that what they really have is a "Don't Be," a "Don't Be Norma 1," a "Be a Man, a Neuter, a Little Girl." I've heard that as a blanket label nut on, ... and what I think is going on is that the women... have been somehow not fitting the feminine stereotype. . . It may be helpful to know if somecne's got a "Don't Be Sexual" or a "Don't Exist at All" . . or just a "Be generally weird," . . but the labeling that someone has a "Don 't Be a Woman" injunction is scary to me because I see that as a subtie way of getting her back into a role.

(Pat)

She goes on to say that part of her feminist perspective means that she has a broader definition of what it means to be a woman than some other therapists might.

I think that maybe more than most people, I'm willing to let women that I see.. . be a woman however they want to be a woman. I think I'm more willirig to let the definition of "what is a woman" be wider. So that if someone comes in always wearing Army boots, thiat doesn't signal to me that she's got a "Don't Be a Woman." It signals to me that she wants to wear Army boots. It may be because it's coid. It may be because she wants soinething heavy on her feet to stay' grounded. It may be because her father always wore Army bosts--but I don't. think it matters.

(Pat)

They see themselves as giving women permission and support to act in ways that traditional sex roles have prohibited--to be assertive, make non-stereotypic life decisions, develop equality of task-divisions in relationships, question her life and her relationships, get in touch with and take the necessary action to meet her needs, feel her cwn strength and power, and become her own person. A therapist described this process in Transactional Analysis terms as "decontaminating the adult around miessages they've gotten about what women's and men's roles are supposed to be and not supposed to be" ( $\mathrm{Peg})$.

Six women spoke of using their Feminist Humanism in therapy by presenting a positive mode $\mathbf{i}$ of ways of behäving women are generally 
conditioned against; being assertive, sexual, independent, a feminist and a woman.

One thing [I do with my feminism in therapy] is what the traditional folks would call role-inodeling. A lot of my work is a function of who I am and how I act. I think I'm pretty gentle but I also think I'm pretty potent. I'm not afraid to be assertive. In my own personal life, I struggle against taking snit from peop?e, and so that gets transmitted into my therapy.

(Teri)

One woman feels that modeling is perhaps the most important thing she does with her feminism--"I'm living feminism and sharing it as I'm living it."

A lot of my teachirig of my feeling and my philosophy about feminism is by example... I'm a hell of an example to all these people down here. . . because I'm very much a woman and yet they see me rebuild my Volkswagen engine; they see me take care of my boat. . . I I feel like I'm a!so a teacher to my other women friends or women who meet me, because of that example, because I do live my life very much for me.

(Diane)

Feminist Consciousness. Coupled with this Feminist Humanism is the added component of their feminist consciousness and feminist framework for analysis, that particular sensitivity to and understanding of the experience of being a woman, the particular problems or prohibitions women bring to therapy, and the limitations sex roles for any models of how a person "ought" to be, however covert, and including feminism) place on a woman's self-actualization and have historically placed on the self-actualization of women. Said one. "To be a feminist means you have to have a certain kind of knowledge" (A.]ice). They are saying that because of their feminism, they have a different--or more encompassing--rerspective or knowledge-base from which to approach understanding of uhat a client is saying and how she came to be where 
she is. This knowiedge-base encompasses not oniy the traditional forms of therapeutic assessment but an awareness of the psychological effects on women of social conditioning, of sex roles, and of a secondary status.

Feminist therapists feel that because they nave more understanding and awareness of the problems a woman may be experiencing, they are less likeiy to discount her problems or perceptions as not reãi, incorsequentiai or less important than her husband's and mora Tikely to "hear" what she is saying, question certain initially-stated goais, and take seriously the pressures of the society on her.

Based on watching some of the men in the training group work and from what I've heard from some of my female friends who have gone to [non-feminist] therapists... I think [a woman] wouid get [from them] . . . a "pat-on-the-head and goback-and-be-the-good-litt?e-wife and everything-wiil-be-oki" [message, the sense of] "Don't really look at those areas 'cause they're too threatening somehow." (Peg)

From their own experiences as women they offer validation of a women's experiences and from their feninist consciousness and perspective a social context and a reality-base from which a woman can check out and understand her own perceptions and experiences.

I think they get [froni me] someone who has a clearer, more whole, complete picture of what our social siructure is like. Anybody who isn't' a feminist and doesn't have that kind of awareness, regardless of how they've lateled themseives, . . doesn't have as complete a picture of our culture and what it does to women and how cutside pressures, situational things and historical things have contributed to that person's psychodynamics [as I do]. So [the client] gets, I think, a better clinician ir me.

(Alice)

They explain that because of their femirist consciousness, a woman is much less iikely to get in therapy the kind of oppression she will get from a therapist whose consciousness is not raised and who therefore 
will respond to her like the culture as a whote responds to women, "fuck[ing her] over in a lot of subtle ways just like the culture's fucked women over" (Lestie).

It's absolutely crucial for either sex to work with somebody who is real aware of the sexual pressures of society and who realiy appreciates, not in an in tellectual way but realiy inside themselves, the equal potentials of the sexes. There's just no way that that isn't going to be conmunicated to whoever you're seeing. . . . If you basically have any kind of prejudice, it gets commicated . . . At the most subtle level you just don't pick up things that someone eise would pick up who wasn't prejudiced.

One of the issues that therapists see all the time is the issue of people trying to decide whether or not to stay in their marriage. It seems to me that the traditional view is very committed to marriage, at the expense of the woman's identity. It's never at the expense of the man's identity. With the best of intentions and the best of theorias, if somebody has that kind of bias, on an unconscious level, it gets communicated. That's something we all have to struggle with. You're taught not to value women as much as men, and the more caught you are in that, the less you can heip your patients to get inrough it.

(Beth)

They are saying that unless a therapist is particularly sensitive to feminist issues or committed to feminism, a certain arriounit of bias witl exist in their therapy no matter how humanistic they feel they are. One woman shared what she thought a ciient got from her as a feminist therapist and then explained how she differed from non-feminist therapists in what she did.

Support for her humanity. Support to come from herself as a whole human being. Support to change. Support to struggle for freedom. I don't think that non-feminist therapists do that. I think that they might say they do [but they really don't]. I think that there are folks who come out of the human potential movoment, some Gestaitists and some Reichians, who actualiy don't like women. Even though they espouse human liberation vis a vis the development of human potential, they still have fixed in their heads some models of how women and men are supposed to be.

(Teri) 
Changes in the Traditiona? Therapy Relationship. Feminist therapists indicated that an important tring they did with their feminism in therapy (and thus that a person would get from them) was to make changes in the traditional therapy relationship. One woman said that a thing she does in this context is to give women "a fair break in therapy" by charging thein only what they can pay. However, generally the changes mentioned were changes in their role as a therapist, in the focus of their work toward action rather than introspection, and in their negative orientation toward long-term therary.

of those changes in the traditional therapy relationship indicated, changes in the role of the therapist were mentioned most frequently, by 15 (of 19) feminist therapists. For 11, changes in the role of the therapist included ways they deait with or perceived the power imbalance in the therapy relationship. As feminist therapists, the relationship they have with their clients is one in which they try to foster, as much as possible, an equality or mutuality and break down the power hierarchy found in traditional therapy. They see themselves as sensitive to and wanting to deal with how they use their power as therapists, and whether they use it to stay distant in the security of their therapist role, to diagnose, to make decisions or interpret for clients, or to discount the importance of power itself as a dynamic of their reiationship. They presented a number of ways of lessening the power imbalance.

Some feel chis can be done by maintaining equality as a basic therapeutic attitude, based either on a sense of common identity as women whether client or therapist, or on humanistic values. 
Given that framework- - tinat we're unequal to begin with--I try to keep my attitude one of, "I don't know better for you. I do have some skills at helping you come in touch with what's inside of you that you cion't have because if you did you wouldn't be coming to ine."

(Leslie)

Two women speak of negotiated fees or of asking for fees themseives rather than sending bills as ways to foster this equality.

Others discuss limiting the oppression of the client by the therapist's power by focusing on the power the client does have in the relationship. Women in particular are seen as out of touch with their personal (and collective) power, thus turning their frustration into "whining and tears and eatirg too much and pills that duil out awareness" (Chery1) rather than action. If in the therapeutic relationship the client is given responsibility for herself, encouraged to get in touch with and take charge of herself, and to be aware of when she gives away her power, allowing others to be powerful over her, to influence her, then she can begin to reclaim her own power and the therapist becomes less a leader/director and more a "vehicle."

I see my whole job... [as making] women take responsibility [for themseives], so that they say "yes" and "no," learn how to go ask for what they want, learn how to get in touch with themselves. [So] if they say, no, they don't want to get irito soniething, I' 17 honor that. If I have some feelings about that or some hurches about that, I']l say it; but I'm not gcing to say, "hey, you're avoiding." Like I know best, or better than ycu. . [ ['m also] non-interpretative. No way would I say : . that I know what this means and you don't.

(Carol)

Part of this is also refusing to accept power that the clients "give away" or project onto the therapist-- "When the client gives me power I give it back" (Karen). Similariy, another therapist explained that increasingly she is turning the responsibility for problem-solving 
away fron herself and back to the women in her groups (tholly).

Feminist therapists a1so give examples of more direct means they use to make themselves more equal. One therapist who utilizes videotape feedback finds this technique also limits her power as the presenter of "reality" and enables clients to perceive themselves directly. "It is critical. . for women . . not to continue always relying on authority figures... [and to] become their own authority, their own best judge of who they are and what they want to be" (Alice). Contracts were also mentioned here as a way to limit the therapist's pover to realms negotiated between therapist and client. Insisting on a contract means both that agendas of therapist and client are overt rather than covert, and purposively limits the therapist's power to lead the therapy in accordance with unstated ideas about what the client needs. By so doing, the client is in an increased position of power, in that she is the one who is clearly deciding what's going to happen, what she wants for herself, and what the therapist's role will be. Two women spoke of lessening the power differential between themselves and their clients by demystifying their therapy skills. They let their clients "in on what's going on" (Joyce) by sharing with them directions they see the therapy going, possible effects of a technique and their rationale for suggesting $i t$, and then respecting their client's decision (the Feninist Humanism above) about which way she wants to proceed. When the women in one therapy grcup wanted training in Gestalt, the therapist began expiaining step-by-step what she had done after working with each person "to demystify the process, so it wasn't so super-special only I could do it" (Karen). Four 
discussed utilizing less "heavy" therapy and increased personal contact on their part with their clients, self-aisciosure to demystify thenselves, and attempts to enter the relationship as more of a person and less of a therapist.

[A client] said something to me that I could have dealt with as a "therapist" but I didn't. . . . I didn't just want to label it transference, even though it seemed like it was that. So I checked.. . out where I was... to see where I stood and [if] I was doing what she accused me of. . . . I think that a feminist therapist would. . . be much more willing to take responsibility for her part in something, not just to chalk it up to something else. [So] I don't approach everything therapeutically... [but] more as me, just as a person to a person rather than as a therapist to a person. (Karen)

The second major change feminist therapists discussed making in their role as therapists, mentioned by nine, was purposively using themselves--their values and experiences--in the therapy they do. They may do this to raise consciousness by enabling the client to identify with examples of the therapist's experiences in discrimination or to lessen the power differential by demystifying themselves as therapists.

One of the things which. I feel is very important (which other feminist therapists would disagree with) as a femirist therapist is to share yourself. I feel it's important tc not put myself up or to come off as somebody who's better than, inore together than [my clients]. That's not where I am. So I'm very much into sharing where I am, sharing what's going on with me, as well as having the person I'm working with feel more in power. It's very important to not piroject a lot of power anto the therapist, [onto] the role of the therapist.

(Karen)

In addition to sharing examples of the discrimination she has experienced, one feminist therapist also shared her positive experiences as a feminist with the women she works with and in the classes she teaches, as a conscious form of role modeling.

[] share] what it mearıs for me to be a feminist and how I consicer that to be a growing dynamic thing in terms of my 
ever-changing life... [I share how] my faminism enables me to see myself as a dynamic, growing person and not a static persor, and how that affects my emotional life, my proressional iffe, my personal life, even my physical life in terms of going out into what several years ago I would have considered risk to play handball . . . or to develop myseif in a wide variety of ways which weren't previously open to me because of my blocking or because of what society told me was right or wrong.

Four of the six women who spoke here of stating their feninist values during therapy did so in the context of expleining its usefuiness in the therapeutic encounter. In explaining their values, a process of negotiation, interchange, or contractirg between them and their clients occurs. One woman identifies herself inmediately to her clients as a feminist, and is listed in resource directories as a feminist therapist. Out of that identification an interchange occurs between her and her clients because

- . ordinarily one of the things [clients] want to know is what do I mean by that. So I define what my value system is and how I believe that is important for me and for my work with women--and men. That [explaining] almost always happens. It's rare that it doesn't happen.

(Alice)

Another vioman uses the statemert of her dias as a forum for contract negotiation around whether or not her cliants are willing for her to work with them to raise their awareness in these areas. Such negotiations are designed to change the power balance in the therapy relationship, as discussed above.

A second group of changes in the traditional therapy relationship discussed by six therapists had to do with focusing on action more than awareness or introspection (or a coupling of the two), particularly action in developing alternatives to therapy in the women's movement. One woman spoke of awareness and action as needing "to go hard in hand" 
(Alice). Another said, "For me, [therapy] is cognition, it is feeling and it is action together". (Marsha). By "action, "they mean that at a certain point they expect their clients to go beyond even awareness of the role of societal conditioning and oppression and to make rea? behavioral changes in their lives, to begin acting differently and to begin finding new ways to jet their needs met.

A form of action mentioned by five of the feminist therapists is encouraging their clients to find alternatives in the women's movement for the needs which are presently being met by therapy. They encourage women to set up women's support groups for themselves outside of therapy. They make it a point to learn about and then give their clients information about various women's groups in the communigy, to a much greater degree than they feel. non-feminist therapists would, with end goals of getting the women out of therapy or cartainly iess dependent on it. One woman said that clients come to her to gat a great number of needs met, and if she does meet those needs, she is actually encouraging dependency and their remaining in therapy which is the opposite of what she wants to be doing. "So lately I have been very firm about saying, 'I'm not here to be ma. Let's look at how you can get. . . those needs met out there. I don't want to see you in here for the next year'" (Holly). Another woman's ultimate goal as a feminist therapist is for the women she works with to become feminists themselves and work for societa? changes.

If they become feminist themselyes, they will love to be with other women, and will support other women, and will be involved in women's groups, and will try to further the women's cause, which is my goal--not an indiviciual solution but a total change of the system.

(Marsha) 
Rajsing Consciousness. Over half the women (10 of 19) described as part of feminist therapy behaviors that are basically consciousnessraising, bringing to a woman's awareness the existence of sex-role stereotyping and sex-roie oppression and the effects of the social experience on her personal experience. It is the idea that re-learning precedes behavioral change. Some do this by asking questions of their clients phrased to "get at" entrenched stereotypic assumptions which women have unquestioningly accepted.

I think there are a whole lot of questions that can be raised.... When women come in and talk about their lives (I'm thinking of mature women now) and they talk about where they have been, I'll say something to them to the effect of, "Did you feel like you were doing what was expected of you at that point?" They'll say, "We1l, of course," and I'll say, "Was that your decision or somebody else's decision? And how do you feel about that?" I consider those feminist things [that I do] which lead into [me saying], "OK. Who are you? What do you want to do?" and, "It sounds to me like you've been spending your life trying to meet other people"s needs. have you ever sat cown and thought about what your own needs are?" That leads into being a woman and what women are expected to do--to make sure to meet [other] people's needs. (Sue)

As they ask questions, they are at the same time modeling questioning behavior and giving women permission to question as well.

A therapist trained in Gestalt described a technique she has used to enable a woman to "get in touch with the . . . implicit and explicit rules in her family about how she was raised to be a woman, how she was treated differentiy than her brothers." With a client whose two sisters, aunt and grandmother were very important to her, she piaced pillows about in the room to represent all the women in the client's family, and had her experience through faritasy the messages she got from them about how to be a women. This therapist explained that she can have a client similarly experience the messages from the men in her 
family as well, and then "link that up culturally through seeing what's passed down through family lines." In presenting this exercise, she intentionally speaks of "the men in your fanily" rather than, for instance, "your father," because "He's a man and by his example he's going to teach and to show to the children what he feels about women versus men" (Lesiie). "Reâity bcmbardment" with video-tape feedback of therapy sessions is used by another feminist therapist to raise a woman's consciousness.

Women are conditioned to . . be aware of how they look on the outside, to do ail this adorning... and to spend [so much] time in front of the mirror, and they still don't know what they look like.... Using video-tape, .. . they can see their passivity; they can see how they sound like children sometimes; [thej can see] how their voice gets... When they're angry and ... When they're relaxed.

(Alice)

Dther women more directly bring into the therapy they do the societal influences they perceive as impacting on the women they are working with. One woman described how she incorporates her own growing awareness of "societal influences" on women into her therapy.

I've become much more aware of the societal influences on women, and I bring that into what $i$ do, . . not only working with individual women's intrapsychic processes but with the effeci of the culture on women... . If the voman is talking about having trouble picking a career, or knowing she wants to move out of the house but not knowing what she wants to do, it's one thing to work only on her own individual indecisiveness and her own passivity, her fearfuiness. It's another thing to point out that of course she feels this way because as a woman in this culture she was trained to behave like that... [or] women will say they're afraid of men. I always used to interpret that as a totally individual thing, that the woman's own personal history alone had contributed to making her afraid-her father was punitive, and so on. But if you look at the larger societal envelope that goes around that, every woman is afraid of men ard they have a lot of societal reasons to be afraid of men. So that [perspective] gets pointed out at the same time that the individual [perspective] does. 
Sometimes conscicusness-raising means they confront sexist remarks made by men in their groups, colleagues or peers.

One Bay Area collective has developed a model of "socio-therapy" which focuses on this relabeling and reframing, taking tnings which are said on a personal level and integrating them with the cultural training women have had. For example, if a woman were to come in and talk about not being able to get along with other women and hating her sister, the therapist might reframe what she said, saying, "We are taught in this society not to trust our sisters... . How could you not feel hatred for your sister--that's what you've been taught" (Marsha).

Emphas is on the Unity of Wonien. For nine women, part of feminist. therapy is giving a woman a sense of her unity and commonality with other women. Some do this in conjunction with raising consciousness, discussed above. Ey presenting the broader cultural perspective of how a woman's personal experience is often a conditioned social experience, their goal is to break down the isolation many women feel about the problems they individually bring to therapy and to promote a sense of unity with other women in the commonness of their cultural experience. One woman described how she incorporates this presentation of the cultural into her therapy:

First I believe it.'s really important for people to come to the awareness themseives, so [I do] a lot of reflecting back iritially, to see if I'm hearing them right, to check and see where their awareness is. Are they really aware that what they're saying is that in fact some of these psychological problems have cone about because of their additional status as a women and the fact that they've been discriminated against, not just because of the sadness of human experiences and the existential situation, but as a woman they have experienced some real hardship and discrimination.

As they become aware of that, I give them support. One of the things I've heard myse if saying on my tapes is, "I want you to 
know, even though this may not be useful for you now, I want you to know that you have a lot of company in that boat." -. . I tell this to women over and over again: "I see women in therapy; I work with women's groups: I talk to women's organizatiors; and I want you to know that's one of the most common complaints I hear. You have women sisters all over saying the same thing you're saying and they all thought they were alone too." I bring in my experience with other women to let these women know that even if they are isolated because they have no social skills, because they feel they're only housewives, or whatever, I let them know they're not alone.

(Alice)

Another woman purposively self-discloses as the means by which she breaks down the sense among women she talks with that they haven't experienced oppression or discrimination as women. By sharing her experiences as a woman, a kind of "clicking" goes on as other women realize that what she has been describing has been irue for them as well. of particular concern for one feminist therapist is her client's relationship and serise of contact with her mother. She focuses on this by having her clients imagine that they are their mothers at a certain age.

"Imagine what you're wearing, what you're doing, and then after a certain amount of time with that, get in touch with what are the disappointments in your life, what have you wanted it to be like and what is it like for you." (Cheryl)

Other feminist therapists promote this sense of commonness by things they do in their therapy to encourage the women in their groups to share with, feel a unity with, and support and nurture each other and to break down the traditional mistrust and hatred women feel for each other. Sometimes, just being in a group with other women with similar problems, particularly sexual problems, removes stigma and isolation. Gne woman related how she "discovered" a new way of enabling women to relate to each other when one of the clients in a group began to describe "what would have been potentialiy a reai heavy Gestalt fantasy." Because the womar was "real good" at getting into past issues, this therapist 
decided to try something different.

So I asked her to choose two or three penple in the group to be her friends. [Then I told her, ] "Now get down on the floor and surround yourself with these friends. And just tell them, friend to friend, about this." . . . I was sitting there--I didn't do anything. I was amazed at the brilliart ideas and answers they came up with, in response to her. The suggestions... I was amazed at the wiscom of these women. I didn't do it [initially] for feminist reasons, [but] now as I'm filtering it through my feminism, I'm saying, "Yeah, wonen are . . not just nurturing and good and sweet and wonderfur, but they re wise."

(Holly)

We talked of the power of this technique for giving women permission to "use their heads," to think. This therapist has felt that many of the Gestalt exercises she had been doing facilitated her clierits getting in touch with their feelings, which women already have permission to do. Since her initial experinent, she has dore more of this. She has also begun to tell woinen to "pick somebody else to talk it over with" when she feels that everyone is curning to her as the therapist to meet their needs. This again facilitates women learning from and supporting each other, as well as removing her from the more traditional therapist role, discussed above.

\section{Continuum of Feminist Therapy}

Interviewees were asked to read two quotes, each of which defined feminist therapy from a particu?ar perspective, and to respond. The quotes were chosen to represent iwo end-pcints on a continuum of definition of feminist therapy. The first quote was chosen to represent the humanist approach (as differentiated from Feminist Humanism above). The interviewer explained that the statement was written as a comment on a returned questionnaire, and that she would ithe the interviewee 
to read the quote and then respond to the question the writer asked:

I have been trained to believe that good therapy means heiping the person develop his or her potential and achieve goàls chosen by him or her. How does feminist therapy differ from that?

The second quote was chosen to represent the radical end of the continum. It was taken from a speech (Duxbury and Heaney 1975) given at a Bay Area Conference on Women's Mental Health. After responding to the first quote, interviewees were asked to read the second one and respond:

Feminist therapy must include making clear the political connections between a woman's personal life experiences and her socially reiniorced sense of powerlessness.

As illustrated in Figure III, reactions to the two quotes, when taken together and placed on a continuum, were clustered into five mein positions, with the left end being more "humaristic" and the right more "radical." Responses to the first quotation are indicated above the line and resporises to the seconc quotation beicw the line. Numbers below indicate how many feminisi therapists interviewed were philosophicalily in agreement with each position. ${ }^{6}$ As shown, most feminist therapists agreed with the first quotation wholly or frartially and disagreed with the absolutism of the second. The following discussion summarizes responses at each point on the continuuin, moving from left to right.

Pcsition 1. The largest group of feminist therapists were in Position I. They said that they didn't think feminist therapy differed

6one feminist therapist agreed with both positions, seeing them as integrated rather than ends of any continuum. "I believe a lot of things and they're all oK for different peop? $\epsilon$ in different situations and OK. for me in different situations.. I think everything exists and should exis:" (Diane). Therefore, she is not included along the continuum. 


\section{FIGURE III}

CONTYNUUM OF RESPUNSES TO PRESENTATION OF TWO DEFINITIONS OF FEMINIST THERAPY

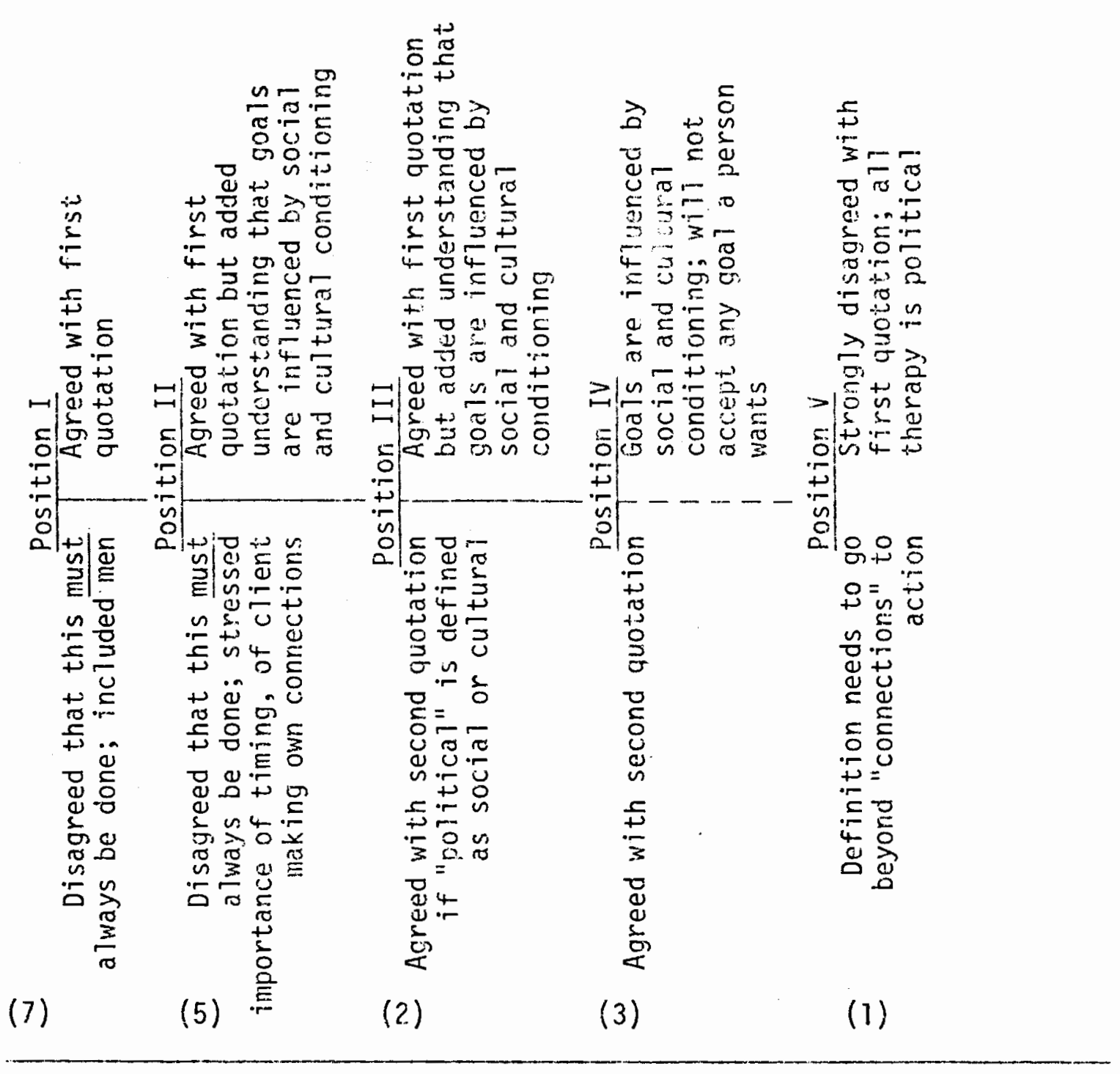

from the definition given in the first quotation, and disagreed with the mandating aspects of the second one. With regard to the first quotation, one responded:

I would say that that's a pretty good definition of feminist therapy. I think the key issue in temis of feminism is.. equality and that naturally implies an equal opportunity 
to make choices and an opportunity to move in whatever direction is congruent with [me], feels good for me and not necessarily [responding out of] those values or those opportunities or those goais that somebody [else] says are all right for me because I'm in therany or [believing] that I can oniy develop this kind of potential because that's [what's] appropriate.

(Sue)

After reading the first quotation, one cherapist said that there was littie differerce in her mind between being a feminist and being a humanist (Peg). This group of feminist therapists feit that the second quotation implied certain absolutes of behavior by stating, "feminist therapy must include . . ." While they generaliy agreed that it could be important for connections to be made between the personal and political reaims and said that they often did so, they do not fee? that they always "must" do so. Severa! therapists said they felt that when she was ready, a woman would make conriections herself and therefore didn't feel that making the connections for her was necessarily appropriate or very useful.

In the process of talking about a woman's life experiences, . . . that comes up very frequently. But I don't think I as a feminist therapist need to "bang" that out. I thirk that maybe I need to ask the kinds of questions that enabie that wornan to say, "Yeah, that's what happened," and if she doesn't say, "Yeah, that's what happened," then she's not ready to see that [yet].

(Sue)

Some questioned the assumptions of the second quotation. One said

that she wasn't sure that the statement that women were socially reinforced for powerlessness was always true, giving as examples women who had had social reinforcement for being powerless and did not end up feeling powerless at all. Several also felt that this definition excluded men, who are also scripted into sex roles and also need liberation. 
Position II. Five feminist therapists qualified both quotations, the first for its lack of awareiless of the role of the socio-cultural focus on women and, like the women in the previous group, the second quotation for its absolutism. They felt that the first quotation was à "starting point," but did not feel that it encompassed all of feminist therapy, omitting ary awareness that the potentials and goals a person feels may well be what she has been taught to feel by sociocultural conditioning. Women in particular, they believe, have been taught to see their potential as limited and to set only certain goals for themselves. They see being a feminist therapist as not merely accepting the goals presented by a client but helping a womian sort out the goals she has chosen, looking at the degree to which she has chosen them because of social conditioning, and then giving her permission to really choose for herself and do what she wants to do.

In these responses to the second quotation, these five feminist therapists said some things that were fairly similar to what those in the first position said. They objected to the idea that to do feminist therapy, they must make political connections, particularly if the client is not asking for that or if doing so would seen to run counter to the therapy process. "There are times when [doing] that fits and times when it doesn' $t$ " (Nancy). One woman said that she doesn't "do politicizing on the client's time." If the client wants that, she will. If the client deries that the cuiture has impacted on her as a woman, conditioned her as a woman, then she will also state that she sees such awareness as an important part of self-actualization but not demand that the client deal with it if she is not ready to do so. Two 
woinell questioned whether it was true that women (or only women) reaily have a "sacially reinforced sense of powerlessness."

Position III. The two therapists in Position III, iike the wonen in Position II, saw the first quotation as omitting the sociologica? and cultural aspects of a woman's experiences, and therefore possibly accepting without question goals that may be very concitioned. However, they hesitated in a total agreement with the second quotation, redefining "political" to mean societal and cultural and perhaps not including in their definition ideas of power structures, irstitutionaiized oppression, political gain, or economics.

Position IV. Three women disagreed with the first quotation and agreed with the second. They saw the first quotation as assuming that goals were chosen outside of any larger contexts. More strongiy than most of the women at the positions above, they stated that there are goals they will not accept. For example, one therapist finds that clients who say they want to get along better with people often mean that they actually want to "find better ways of submerging their general anger so that they're more acceptable as they weave through the world." She also explained that sometimes, when women say they want to change their image of themselves, what they mean is "to weigh 110 pounds and he loved by all" (Elien). Those client goals, they are saying, are never their goals as feninist therapists.

I will not he?p anyone fuck over another person. I will not help anyone let herself or hinself be fucked over. . . One example is a man $I$ had in therapy. He was 50 years old and had a job that was making him miserable. Wot only that, he had a drinking problem. I helped him stop drinking, helped him get it on with his wife. Their previously uptight noncommunicative reiationship took a turn toward being an open, 
more fun relationship. . . The next thing he wanted to work on was to adjust to his job. After a lot of probing it became clear that he would be adjusting to the most awful oppression, and I said I could not help him dio that. I could heip him change the situation. I could give him psychological support to get another job or organize in the situation to make the job more comfortable, but I wouldn't help him adjust to that job. I would never help women adjust to becoming better housewives or a better secretary. I might help a woman take power in a job such as a secretarial job so that shie's not as oppressed, but I'il never help her become à slave. If that's what people's goals are, they' 11 have to see another shrink. But I'll probably get in as many licks as I can about how I think it would be bad for them to do it. (Teri)

These three women agreed fully with the second quotation, saying that making these connections (or making sure a client makes these connections) is an important part of their therapy.

I don't do a lot of lecturing to connect things but I would say certainly making connections. I would say that more often than not I go for the cultural scripting as opposed to the individual scripting. . . . If I see a woman responding to a situation that seems very universal or very generally much like a whole lot of other vomen, I'm Tikery to say, "You know, the problem you have is the problem a lot of women have." That has two functions. One is that it raises the awareness of female oppression. The other thing is that it makes a woman feel less isolated and less alone. In that sense I'n always making political connections.

(Teri)

Position $y$. Finally, the woman in the fifth position disagreed with both quotes, going in her definition of feminist therapy beyond the radical end of the original continuum. She disagreed with the first quotation because it did not include any understanding of the political aspects of ail therapy, the ways in which therapy is a means of social control and used to maintain an oppressive society. She disagreed with the second quotation because to her, feminist therapy is "more than 'making clear.' That's just insight." For her, feminist therapy is "cognition, it is fecing, and it is action together--some 
kind of action and some kind of commitinent to a revolutionary movement" (Marsha).

Men as Feminist Therapists

Feminist therapists were asked if they thought a man could be a feminist therapist. Responses clustered into six categories, ranging from an urqualified "yes" to an unqualified "no." The continum in Figure IV shows the rarige of responses, with the number of women in: each category listed below the line.

\section{FIGURE IV}

\section{CONTINULM OF RESPONSES TO QUESTION OF \\ MEN AS FEMINIST THERAPISTS}

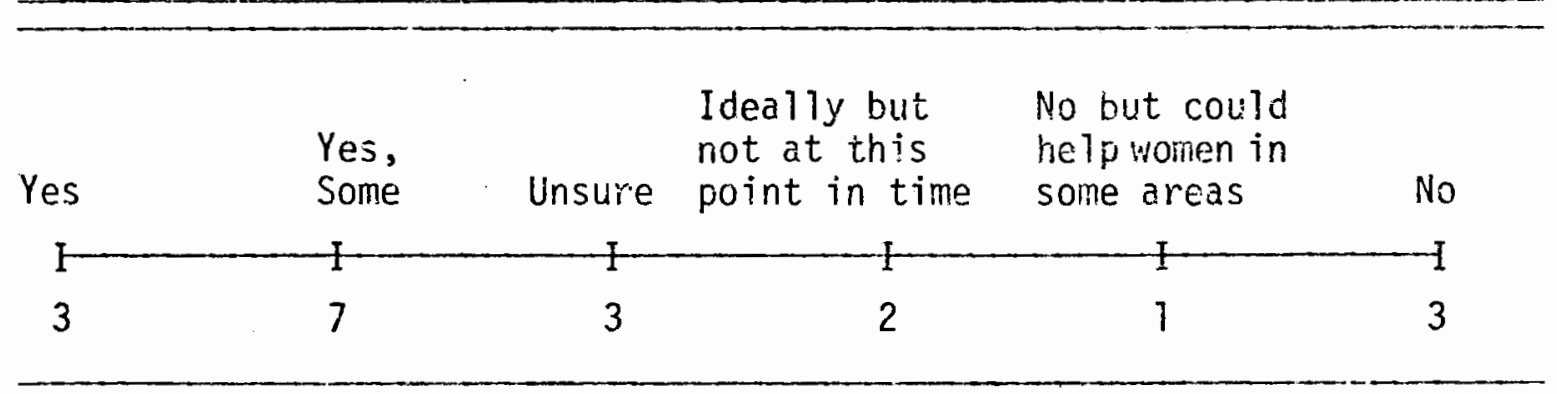

As the continuum illustrates, the greatest number of feminist therapists believed that some men could be fominist therapists, and the responses on the "yes" side of the continuum outweigh those on the "no" side (10 to 6$).^{7}$ Discussion of responses at some positions on the continulim follow.

${ }^{7}$ It is interesting to compare this belief with the results from the sample frame development. In the process of developing the sample frame for this research, of the 273 names generated through the natural system as potentiol feminist therapists, only four màle names were elicited, three in Seattle and one in Portland. Of those four, only the one in Poriland said he considered himse if a reminist therapist, leaving ore male feminist therapist in the population and 103 women feminist therapists. 
Yes, some. This was the most frequently given response, indicated by seven of the 19 feminist therapists interviewed. They felt that there were some few men who, if they had certain critical characteristics, could be feminist therapists. Critical characteristics listed included being sensitive to and concerned with feminist issues, having a feminist analysis of sex role oppression, being aware of the impacts of sex roles on his own growth, struggling with his own sexism, living a feminist consciousness in his life and in his therapy, and developing his nurturing and intuitive capacities. One therapist pointed out that possessing any of the qualities above did not necessarily make a man a feminist therapist, but that they were qualities necessary in order for a man to be a feminist therapist. These seven women seemed to feel that mer had the potential to be feminist therapists, although they often had not developed that potential in actuâtity. Three therapists saic that there were certain limitations for any man in being a feminist therapist.

I think men can do it . . A man can't be a woman. A man can't know what a woman feels to the extent that a woman feels what she feels. . - A man is more likely to have cultural conditioning as a man that is different that a woman's, so therefore may not have as much insight into that, but I think a man can have a consciousness of those things and try to work in accord with that conscicusness ard work in the same kinds of ways that a woman aitempts to, in overcoming those things.

(Joyce)

One said here that a good feminist therapist, no matter what her politics, "is going to be a lot better for most [women] than any male therapist, no matter how radical his politics and no matter how much he avows his feminist position" (Teri). 
Ideally but not at this point in time. Two women felt that idealiy, a man could be a feminist therapist, but given the situation at this point in the development of the society, he could not.

Not now. Though I know soine men that consider themselves so enlighteried, [who feel] that they're enough in touch with women's problems to deal with women. And I simpiy don't believe that. There's no way that a man can jump outside the culture. He was raised in it; he is sexist by definition. I don't think there is a man yet enlightened enough to step outside of that or on top of it no matter how important it is for him and how hard he tries. . . There's so much mitigating against a man working with a woman. The whole thrust and the weight of the culture is behind his attitudes towards women, and it's exacerbated by his being in the position of a doctor and she in the position of a patient. So what happens is not only what happens between a man and a woman--it's dcubled betweer: a male therapist and a womar: patient. So .. . I would say ail women, at this time, if they want therapy, must go to women therapists. I renlly believe it. (Leslie)

No, but he could help women in some areas. The feminist therapist in this position said that while she felt that any man labeling himself a feminist was an "unfair appropriation" that "set wrong" with her, she did feel that there were some areas, such as helping a woman get in touch with her own power if he had gone through that himself, in which a male therapist couid be helpful to a woman. She went on to say that similarly, a woman therapist could not necessarily help another woman around feminist issues unless she had had "The Feminist Experience" (Pat).

No. Finally, three therapist.s responded to the question with unqualified "no's." One woman said she thought a man couid perhaps be sympathetic, but that he could not be a feminist therapist. One therapist said that a man couldn't be a feminist therapist because he had inherently too much power with women. She feels that with a male therapist, there is so milch culturally conditioned "seduction" going on between him and 
the womar client that his words carry a dangerous amount of weight. She feels that with a woman therapist, the therapy "doesn't have the same stickiness, the glue, that happens between men and women and that I think even the best male therapists use, whether they know it or not" (Ellen). Lastiy, one therapist said that a man couid not be a feminist therapist because

- . men are in some ways the people who are oppressing me. I mean, there are only two sexes in tinis world. . It makes sense to me that if $I$ ali the oppressed, somebody else is doing the oppressing. . . So they can't do [therapy with women].

(Marsha)

Definitions of Feminist Therapy

Definitions of feminist therapy were arialyzed within a six-square grid and sorted as follows: 1) according to whether the definition (or component of a definition ${ }^{8}$ ) focused on human commonalities and human potentials, classified as egalitarian, or on women and/or the differences in people and perspectives brought about by or necessary due to sex roles and sexual oppression, classified as sexual differentiation; and 2) according to whether the definition (or component of a definition) dealt with client seif-actualization (potentials, goals, personal power), changes in therapy process and/or in the role of the therapist, or social awareness and social action on the part of the therapist and/or as dirertiy commuricated to the client in an educative (consciousness-

8n number of definitions contained several components. In order to preserve the complexity of the response, definitions were separated into component urits and each compenent was listed separately. Thus, it is possible for one respondent to have more than one response in a chapter, and/or resporises scattered among several categories. 


\section{FIGiRE $V$}

\section{DEFINITIONS OF FEMIHIST THERAPY}

\begin{tabular}{|c|c|c|}
\hline 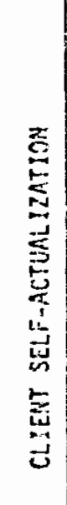 & 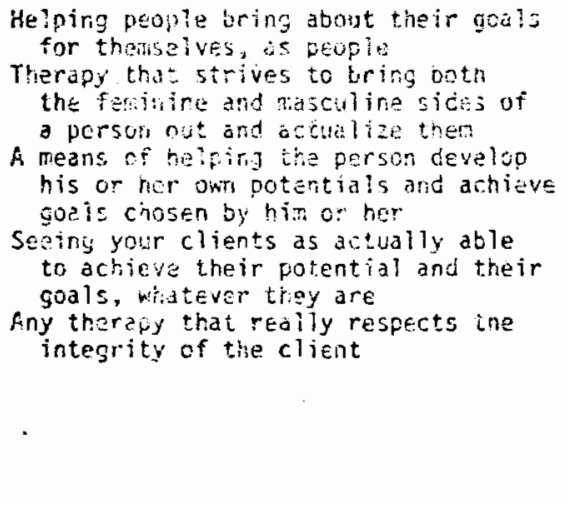 & 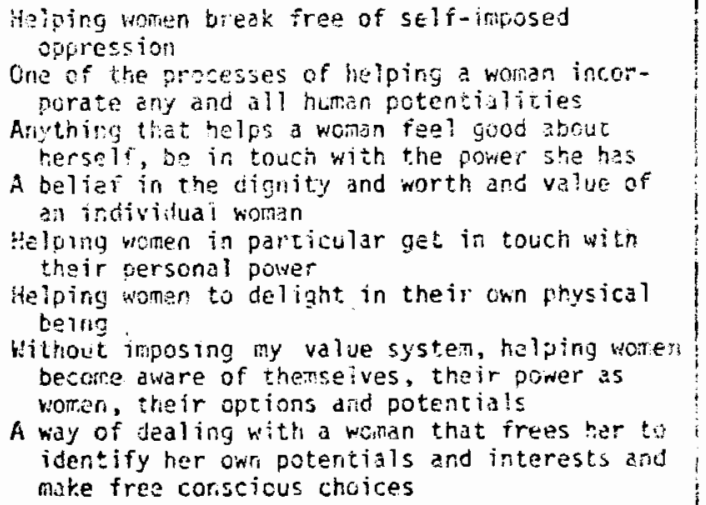 \\
\hline 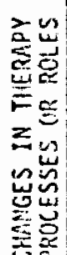 & $\begin{array}{l}\text { Seeing your :lients as mure fque? to } \\
\text { you in the therapy situation }\end{array}$ & 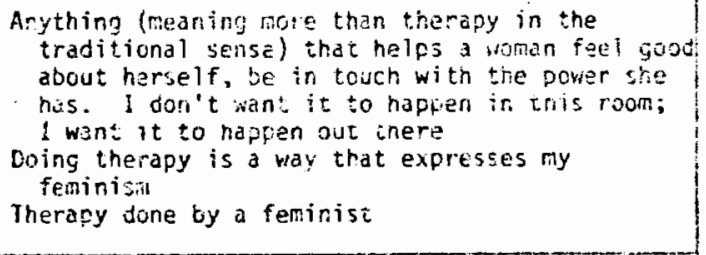 \\
\hline
\end{tabular}


raising) process. Figure $V$ shows the dofiritions of feminist therapy given by feminist therapists sorted according to this system.

In this case, only three women listed definition components twice in the same category and therefore, for purposes of comparison, the absolute number of definitions (or definition components) will be utilized. Most frequently listed were definitions incorporating sexually differentiated social awareress and social action, followed by sexually differentiated client self-actualization. The other four categories were listed less frequently, and with fairly equal frequency, as Table XII indicates. Definitions incorporating social awareness and

TABLE XII

CATECORIES OF DEFINITIONS OF FEMINIST THERAPY

Category

Total number of Definitions in Category

Sexually differentiated social awareness and social action

Sexually differentiated self-actualization

Egalitarian self-actualization

Egalitarian social awareness and social action

Sexually differentiated changes in therapy

processes and/or changes in terapy

relationship

Egalitarian changes in therapy processes

and/or changes in therapy re?ationsinip

11

7

4

3

3

2

social action are listed most frequently (14 times), followed fairly closely by definitions incorporating client self-actualization (11) and much less frequently by definitions incorporating changes in the therapy process and/or role of the therapist. This would seem to iricate that 
feminist therapists see feminist therapy as concerned with client selfactualization and consciousness raising rather thari changes in the therapy itself. Definitions based on sexual differentiations greatly outrumber egalitarian definitions (21 to nine), indicating a clear focus in these definitions of feminist therapy on the particular role of women, the results of sex mles and sexual oppression, and the perspectives designed to incorporate that.

As in the definitions of feminism, most definitions were terse and included in figure $V$ in full. Two therapists specificaliy differentiated between feminist therapy (or, for one, feminisin as therapy) and therapy done by a feminist, saying they did the latter and were aware other feminist therapists did the former, wondering if what they did would really be considered feminist therapy in the strict sense.

IV. HOW DOES FEMINIST THERAPY PERCEIVE AND INCORPORATE THERAPEUTIC ISSUES?

During the interview, feminist therapists were asked in a number of questions how they perceived and/or incorporated therapeutic issues-.. in particular values and directiveness, structural issues, diagriosis, working with lesbian clients, power issues, self-disclosure and answering client questions, therapy as political or apolitical, and the possibility of losing potency by incorporating feminism. Their responses compose the first seven subsections of this section. In addition, two more general questions in the interview asked feminist therapists to list any issues or struggles for thelil currently in combining their feminism 
and their therapy and to give an example of a time when it has been hard for them to incorporate their feminism into their therapy. In response to the question about current issues (and at other points in the interview when something was specifically mentioned as an issue or a current struggie), 34 issues were raised (some several times), of which 20 had to do with the therapeutic issues (most frequently with self-disclosure [5] and with values and directiveness [5]), and five with relationships with other professionals. The former are included in the discussion of each issue as it is presented, and the latter are discussed as 0ther Therapeutic Issues. When giving an example of a time when incorporating feminism into therapy was hard, eight (of 16) feminist therapists discussed their difficulty in working with women involved in a "traditional relationship" who weren't interested in or were threatened by feminism, and five of those 16 feminist therapists discussed their difficulty in working with women who found in their feminism or lesbianisin reasons to be critical of or remove themselves from the therapy process. The first of these responses is included in the discussion of values and directiveness, and the second in the discussion of working with lesbian clients. At various points in the interview, feminist therapists spontareously voiced their opinions about different theoretical orientations. Those comments are also included as Other Therapeutic Issues.

If it is possibie to make the distinction, this section deals with issues that arise (or could arise) for a feminist therapist (or between feninist therapists) as a therapist trying to incorporate feminisin into therepy and in the next section with issues that arise 
(or could arise) for a feminist therapist (or between femirist therapists) trying to incorporate therapy into feminism.

\section{Vaiues and Directiveress}

Since the issue of values was discussed in the literature, the following probe was utilized to provide information about what feminist therapists believe and do with their values (particulariy feminist values):

Some therapists have told me that although their values are feminist, they don't feel they have a "right" to bring those values into therapy and attempt therefore to be as value-free as they can. Others feel it is important to be "up-front" with their values. Where are you at with this?

In addition to the replies to this particular probe, the whole area of values (their role in feminisi therapy, questions of directiveness) was repeatedly mentioned in responses to other questions. The narrower issue raised by the probe, although not asked directly, was whether feminist therapists believe therapy can--and should be--value-free. In their responses to the question, nine feminist therapists said in answering that therapy could not be value-free. In response to the larger issues of therapeutic directiveness versus client self-determination around feminist values. six feminist therapists saw their valuas coming through indirectly, two folt their value of client self-determination mitigated the need to state other vaiues, eight were "up-front" but attcmpted not to be directive, and three were cleariy directive.

Therapy as Value-Laden. Although the question of whether they thought value-free therapy was possible was not asked directly, nine feninist therapists began their answers to tris probe by asserting 
that they believed all therapists have values and that it was impossible to be value-free.

I think it's impossible to be value-free. It's like leaving yourself out the back door. You can't do it. Unless you are completely analytic, . . . and I don't see how a feminist could also be analyitic at the same tinie--they're just mutually excluding in so many ways.

(Betsy)

They believe that whether a therapist overtiy states her biases or attempts to hide them, they nonetheless will come through in one way or another. "With the best of intentions and the best of theories, if somebody has . . bias, on an unconscious level, it gets communicated" (Beth).

In response to the question about whether they thought they had a right "to be up-front" about their values or should remain value-free, three positions with regard to values and directiveness emerged, as listed below, with the numbers following indicating how many of the 19 feminist therapists interviewed were in each category.

Position 1: My values do come through indirectly in the questions I ask but I have no right to impose them on clients .......... 6

or I am very "up-front" about my strong value of client seif-determination and it mitigates my need to state any other values I may have unless I am asked........... 2

Position 2: It is important to me to be "up-front" with my values but I don't want to push sonieone who is not in my "space" or not ready to hear me............ 8

Position 3: I have values I want to put out to my clients.............. 3

The following discussion will elaborate on each position.

Position 1. Six feminist therapists said that while they believe their values did come through in the ways they asked questions and ?ed 
the therapy, they did not feel that they had any right to impose their values on their clierts. In contrast with those in the other two positions, they seemed to indicate that the evidence of their values in their therapy was more inevitable than intentional and in their responses focused on the dangers of value imposition. As one said, "I don't think you have a right to impose [your values] on somebody else but it seems almost impossible to me not to have your own values come through." This therapist gave as an exarmple a client she was seeing whose 14-year-oid daughter got pregnant. This woman had decided to cut herself off from ail her friends because she was ashamed to mention this and afraid to see them and not mention it. Through the process of helping this client "decontaminate her adult" around her values (coupled with the very fact that the therapist identified those ideas as contaminations), this client knew that the therapist thought that what had happened was not a terribie thing and that it would be not just all right but helpful for her to talk about this with her friends (Peg). Similarly, one therapisc explained:

Mostly I think [my values are expressed] by the way I set up the exercise. The things that are picked out to dialogue with are in essence saying. "These are things that can be looked at." By' even saying that, I'm saying that this doesn't worry me or shock me--my belief is that these are all parts of my womarness or your wormanness.

(Cheryl)

Another feminist therapist said that she was aware that more often than she would wish to, she negatively reinforces traditiona? roles rather than allowing people freedom to have those roles.

To a much greater degree than the feminist therapists in the other positions, those therapists holding Position 1 stress women coming to awareness when they are ready to do so and their desire as therapists 
not to impinge on that process by more overt value statements which may convey to the client any sense that this is what she "should" do or believe. They don't feel as therapists that they have a "right" to "lay their trip on somebody" (Ann). Instead, they see their role as at times being a catalyst for awareness but ofter, find that women choose not to explore these issues further. "People who come [to see me] who are not feminist can leave without having one bit of change in that area" (Ellen). In accepting this, they are the least directive of the three groups. "I'm not pushy about the feminisin.. I'm not out there waving the flag" (Peg).

I see my own feelings arid my own biases strike a chord a lot when I'm working with women, to the point where I almost have tc temper miself, because there's a point where my own biases cannot take over therapeutic desigr.s. I have to be careful sometimes to just rot say, "You have a right to do that!" and [instead work to] help the persor see that in themselves.

(Ann)

I don't think I as a feminist therapist need to bang [that feminist consciousness] out. I think that maybe I need to ask the kinds of questions that enable that woman to say, "yeah, that's what happened." And if she doesn't say, "Yeah, that's what happened," then she's not ready to see that. (Sue)

With regard to goals and directiveness, several stress the client's right to accept traditional roles "if that's what they want and that's what they enjoy" (Sally), and to "sayy no" to any of the values the therapist may be presenting. Only one of the therapists holding Position 1 gave any examples of being overtly directive, and this was in an instance in which the therapist became very frightened by the client's behavior and therefore insisted that a woman contact Alcoholics Anoriymous.

Two therapists, included as a variant of fosition 1, indicated that because their foremost value is client self-determination or 
freedom of choice, they find themselves being overt about that and finding that value overriding any other values they may have.

The value that I olways try to go with. . . is [a concern with] whet's important for that other person to do for themselves and to totally support that. I can't say [i'm] vaiuefree 'cause that's another illusion. I think triat [this belief in the importarice of] a woman going whatever route she really is needing to go is a possible value that I really do have... I try to be very aware of when a personal value of mine is getting in the way [of that]. ... [Above a11] I assert the value of freedom of choice.

(Nancy)

These two therapists said that they thought they differed in their responses to this question from other feminist therapists. One wondered whether she was even a feminist therapist, feeling that most feminist therapists would not support a woman choosing not to be a feminist, whereas she would.

One thing I wonder is whether a feminist therapist would support a woman's desire not to be a feminist. For me, I trink it's important that I not decide that other womer: have to be like me. [I think that] it's really unethical for a therapist . . to have a creed, whether that be getting people back into the church somehow or [believing that] the only way that people can really be $O K$ is in a heterosexual marriage.

(Pat)

The second therapist described herself as "going easier" on the presentation of cultural infiuences on a woman's experience that other feminist therapists she knows because she feels it is most important for a therapist to help people come to their own conclusions. However, she also described her work with pre- and occasionally orgasmic women as an example of an exception to her focus on a less directive, less didactic therapeutic role. When she does these groups, she is intentionally different from the non-directive humanistic way she is in her individual therapy. Here she is clearly the leader, working for pragmatic changes in sexual and assertive behavior. 
Position 2. The largest group of feminist therapists interviewed (eight of 19) held to the second position, that it was important to be "up-front" with values and yet rot to push someone who was in a different place than they were, perhaps not ready to hear what they had to say. They seem to differ from those holding the third viewpoint in that they are "up-front" with their values less because they believe those values are always right for their clients but more because they value being "up-front" itself, particularly because it weakens the power the therapist has whose values are hidden or who denies she has any values. (Under Other Therapeutic Issues, this is discussed in relation to Freudianism.)

It's part of being clear with peop?e and not laying a trin on them and respecting them in the sense of giving them the information to make their owr choices and make their own decisions and for us to have an explicit equal kind of agreement rather than my manipulating them . . . in the context of traditional psychiatry.

(Joyce)

Urilike those in Position 1, several stress here the importance of separating out and cleariy labeling value statements for what they are.

As far as I an concerned, that idea about valueless therapy . . . is empty, because good therapists have values. I think to set a rule for yourself that you will not share those human values. . does your clients a disservice. [I believe you should] separate your values and say to a client, "Those are my values. That's how I believe. I want you to know where I'm coming fron so you won't think I'in trying to make you into something different--but I believe this to be good." That's respectful of other peopie. Otherwise those hidden values are back there working all the time anyhow, and the client thinks, "There's something going on back there. Why can't they teil ine what it is."

(Alice)

They are saying that those value statements which the therapist clearly labels as her own views are in turn values which the client can knowingly accept or reject, can allow herseif to be influenced by or refuse to be 
influenced by. Values which are denied or hidden are still infiuencing the client, but it is without the client's knowledge or consent. One therapist explained that she is working toward being clearer with her clients when she sees a conflict beiween her "bias towards freedom from sexual roles or roles of àll sorts" and her client's position.

Sometimes 1 state that I have a bias in a certain direction that's different from theirs and then we need to make an agreement: to agree to disagree or let me influence them or raise their consciousness or not. . . . I'm evolving towards being clearer [about that], and more open and explicit about agreements with people rather than assuming we have an agreement, [rather than] my working in my direction and they're working in theirs and not really being very explicit about checking those things out.

I more frequently state what my biases are racher tinan show them by the things that I comment on over time. I more explicitiy state them when I become aware that they're very essential to the subject or the issues we're dealing with or the problems that the person has. [For example,] someone's talking about their relationship with their husband, and they're having some conflict about their roles. Then I feei it becomes necessary for me to say something about what my biases are in terms of gaining freedom from such roles. Sometimes there's a conflict with the person and then we have to figure out a way to work that out.

(loyce)

More than those feminist therapists with the third viewpoint, these women are concerned with the impacts of their values on their clients and with tempering their potential directiveness.

Some therapists in this group indicated that the degree to which they overtiy state their values depends on the degrea to which a woman has enough of a feminist: or radical consciousness of her own. These cliencs aren't expecting a therapist to assume a traditional role, but apprcach the relationship as one of equality and mutual respect and want certain kinds of teaching and consciousness raising from the therapist. Other clients, however, while recognizing the roles they are playing, are afraid to upset the balances in their families or find feminism 
threatering. "Bopping [them] too hard with the idea of some of the cultural implications of some of [their] statements" (Les?ie) or demarding they make certain changes may mean they will never return. One therapist talked about ways she has devised to deal with this that are non-threatening.

Usually the way $I$ go about it is talking about women in tarms of their power, what they've done with their power or haven't done with their power. If a woman comes in and says, "My role is to be there for my man, to be available, to . . . put myself second," I will talk about that in reference to the effect [on her] of doing that. I'll do a lot of stuff with her about her body. [J'li have her] make herseif in a waiting place, and [help her see] what that does to her body, get her in touch with how she holds, how she tenses, how she denies and how she tucks feelings away... I just get her to pay attention to what it's doing to her, and then say, "Now you have a choice. You have a choice of whether or not you want to learn how to use your power in a more assertive way so that you're not cutting into yoursalf. If that's too threatening to your relationship, I want you to know what you're doing and that you're choosing not to do anything about this." It's her choice. I'm not into trying to push her to change her lifestyle if she doesn't want to, but I'm going to let her know how I see what's happening.

(Carol)

One therapist in this group said she sees many clients for whom sheer physical survival, not feminism, is the concern. She feels that bringing up feminist issues to them is an inappropriate intrusion into their often fragile lifespace. Generally the degree to which these therapists are directive or highly overt with their values at any point in therapy depends on their assessment of the client and the therapeutic relationship.

[Before I state my values directly,] I need to have a relationship with solnebody and I need to have some sense that they ${ }^{2}$ re not just going to react defensively and run away if i question [something]. I will not accept. something that I disagree with, but I might not respond. When i confront somebody depends on when I feel like it's going to be productive. [Ari example is] a patient [i have] whose stated goan was to find a husband. . . I know [at some point] I started to ask her [questions]. I think the intial guestion $i$ asked her was how she felt about the fact that I wasn't married. At first her response was, "Wen, you're divorced, so it's different. You wied to be married. 
That proves that you're oK.: . . Some of the other questions were, "Would you want a marriage like your parents' marriage? Is that your goal?". . . Recentiy, we've gotten a lot into what she might want to do for herself professionaliy. . . . [And] she's real clear at this point that $I$ do not see marriage as the live-happily-ever-after kind of thing. (Eeth)

Therapists holding Position 2 seem to differentiate between stating their values, which they do clearly and purposively, and attempting to use those value staterients, designed to reduce the power differential and promote a "straight" relationship, to explicitiy influence or direct clients towards their values.

I tell people where I am. But [I tell them] where i am not [to say] that they should have to change, but that they should know what they're dealing with, . . . my position. I don't have a "should" that you should be more alive. If you want to be dead, if you want to be crazy, and if you want to be living the way you're living, that's your choica. Blit I want you to know what you're doing.

(Carol)

While one therapist does rot attempt io infiuence people explicitly, she does attempt to be very explicit about when she is being directive in therapy. When she feels that what would be most effective at a certain point in the therapy is a certain technique, she tries to explair to her clients what it is and why she is suggesting it, to acknowledge her directiveness and negotiate with them how to proceed.

What I try to do... is just explain to them what I'm seeing and at the same time I'm doing that try to give them every opporturity to agree or disagree or say what they want. [For example,] I could say, "We've gotten to the point of using this techrique. This is my idea of something we can work witn. Are you in agrement with using that?" If they say yes then I try to explain, "well, I think that putting your mother over in this other chair and having this corversation with her is a way that will do this. I know that. . . I'm choosing to be directive when $I$ do this and these are sone of the things that might come cut of it. Do you want to try it?" If they say no, then we don't do it. I'm naturally hesitant frot from my political consciousress but just from my own hesitancy) to push anything on anybody. I give people lots of permission to say no, even more than I should, than would be effective. (Joyce) 
One therapist who always initially identifies herself as a feminist because of the opportunity doing so provides for value--sharing and value-openness explained that if a client is totally denying the socio-cultura? implications inipinging on her, then this therapist will state that a vaiue of hers is that women-rieed to look at those things in order to be fully self-actualized.

What I would do is say, "I believe this. I think it's important. When it becomes iriportant for you, or when you have some time and space in your life, I think it might be a usefur thing for you to explore. . . ." But I don't do politicizing on the client's time, so to speak, unless that's what she wants.

(Alice)

Similarly, one therapist in this group said that, although she gererally doesn't believe in telling people what to do or feel she has "a right to push someone who's not in my space toward feminist thinking" and may talk about her thoughts and feelings but iries not to get emotionally involved in what a client does, there are times when she finds herself feeing very strongiy about a feminist issue. In this case, she will label what she says as her vaiue, her position. An example was a client whose housemate (male) told her that she would have to end her individual therapy before he would consider beginning the co-therapy she wanted, and then it would be with his (male) psychiatrist.

I came down really heavily--would she essentially abandon someone she had no complaints about in order to pacify him... That's one of the few times that I can remember taking a feminist issue and bouncirig up and down on it. [I said to her,] "I'm taking fu?] responsibility [for what I'm saying]. I'm coming off the walis, I'm so furious. How come you're not angry?" - . But that was [clearly] my value.

(Betsy)

One therapist in this group said she does inform her clients of certain rallies and marches she feeis are politically important; another reiers women to books and consciousress raising groups. However, while 
stating their values, their emphasis and their focus again remains on clierit self-determination above therapeutic directiveress.

With regard to congruence between the values and their client's goals, one therapist said that while there are certain goals she will not believe, she would probabiy not be as directive as to state that initially but would question the goal, attempting to "be straight but a) so not put her down."

If somebody made a gca! that was, "I want to live a nice middle ciass married life and be slibservient to my husband, . . ." I wouldn't believe [that]. I can't believe that if a person staried feeling her sense of power and her sense of strength, staried feeling good about herself, that she would ultimately choose. . Something trai oppresses her so much. in other words, if they're choosing it, they're choosing it out of not seeing another side. . . But I don't know if I'd just say, "I don't accept that." . . I'd find out more about it. I wouldn't put her down. A persen who would say that probably feeis bad enough about themise?ves as it $i s$. I would talk about it. I'd say", "What makes you wart that goal? How do you feel when you're in that position?" I'd ask them some questions about it, and would ultimately state that that wouldn't be a goal that I would want her to choose.

(Karen)

Another may take a stronger position, depending on the degree of discongruity between her values and her client's goals. If a client's goal differed radically from her values and belief system (for example, a woman wanting breast implants to be popular with men), then she would have to say, "Look, I cannot help you with those goals. They differ so radically from my values and my belief system that there is no way I could work with you on that" (Alice).

Position 3. Those three women in the third grouping felt that presenting their values was a critical aspect of their therapy. Many of those values rad to do with feminism, and in those instances, presenting their values was a critical aspect of their feninist therapy. 
I don't see how you can be a femirist and not assert your feminism to people you're in relationships with, or work with, or work for. One of the reasons I'm a feminist is because i think it's good for peopie to be feninists. It's better for people to take an advocacy for women's liberation than not to do it.

(Teri)

For example, one of these women at some point in therapy states her beijef in the importance of women making the decision to change oppressive aspects of their iives and ultiriately become feminists, saying, "I would like everyone to be a very strong feminist."

A lot of pecple (and especially women) come to therapy in general wanting permission to be miserable but lifted somehow. You know, [saying,] "You do it for me. I'm never going to make ariy changes in my life. I'm going to remain married and waxing floors and not having a life of my own, but I vant to feel better." I immediately break that myth, and I say, "That's not possible. I can't deliver." I'm very honest about where I am . . with people. (Marsha)

other values may have to do with anti-capitalism or existentialism, but in any case they believe strongly in clearly stating to their clients their beliers and value systems because they do want their clients to adopt them, because they think it would be better for them to adopt them.

These women holding Position 3 seem to be the most willing to be directive with their clients. Orie describes herself as "very directive," and explained her rationale:

A great portion of peaple's psychiatric difficulties are based on sex-role oppression, meaning the way they were trained to fit into some preconceived ideas abcut what men and women are supposed to be.. as well as other forms of oppression in the society. Then it falls on me to illuminate when I see it enierge the areas in which I feel my individual clients are affected in that way.

(Teri)

With a Native American gay woman who felt "like a very 'not OK' person," this therapist began in the first sessicn to present her understanding 
of how culturel and sex-role oppression led to their woman's unhappiness and to counter the cultura? messages with the positiveness in her own ideas and values.

The first thing I said to her was, "Your unhappiness has to do with the fact that [you dre] a voman, ind a gay woman, and a Native fmerican woman." [I said] that I thought it was important for her to find out what was good about all those things.. . So that's what she started to work on. I was very directive in that sense. The inessage I gave her was, "Who you are is fine." And, "Be who you are." (Teri)

When another of her clients wanted to lise therapy to adjust to an oppressive job, she explained that she would support him in getting another job or in organizing in that situation; but she wouldn't help him adjust to an oppressive situation. One of the other therapists in fosition 1 said that if a woman told her she was married, had a good relationship with her husband and two kids and didn't understand why she was depressed, she would imnediately begin questioning those statements, at least to herself and over time begin giving her client permission to question then as well. This therapist stressed that with clients such as this one who are beginning therapy and have no feminist consciousness, she is much less directive. As they get permission to question and to make connections, she states her values more clearly and more strongly (Marsha).

Difficulties with Women in Traditional Relationships. In giving an example of a situation wher it was difficult for them to combine feminism and therapy, eight fof 1\%--none of whom, interestingly, in Position 3) spoke of wondering what to do with those clients whose biases or whose oppression are apparent to them as therapists, wheri in the first instance the clients are not wanting to change those biases 
and in the latter, the therapist fears promoting awareness of oppression runs the risk of radically changing a person's life. As one therapist wondered, "What do you do if people are going along in ways you don't accept?" (Ellenj. The issue for them was to what degree they felt comfortable "pushing" their femirist consciousness.

I struggie with . . Wanting to educate peopie more than I do becalise that rins into conilict with both my belief and the expectations of the setting. . . that I not push my thing onto people that I'm working with, that I respect what they wart and where they are--and I'm wanting to influence them more... There's a confijct there [for me]. (Joyce)

In all cases, the example they gave had to do with a worian who, in one way or another, chose her relationship with a man over what the therapist saw as the client's own needs for personal growth.

One example given invoived a group of women who had been in a nocharge therapy group during the day. When the group was changed to an evering time and a fee was asked, many or the women were afraid to express to their husbands their desire for therapy arid to ask assertively for the money and the evening away from home. In addition, these women had begun to see that they could "start waves" in their marriages if they remained in therapy, continued to realize the degree to which their needs were not being met ard to make the kinds of changes they had been making to meet those reeds. At this point, many chose not to continue (Sai7y). As one woman said to another therapist, "If I keep seeing you, I'll have to leave rily husbarid, and I can't do that" (Karen). Another woman gave an example of a couple she was seeing for sex therapy. They were in their mid-fifties, and highly re?igious. She described their relationship as very stereotypic, with the woman taking a second-place position in the marriage, martyring herse if and remainirg 
firmiy in the role of mother to her husband and chiloreil. This woman was not ready or wanting to recognize what the therapist saw as her oppression in the marriage and as a woman, and the therapist felt it would be unethical for her to push this woman towards feminism even though she would have liked her to have those awarenesses. She felt that if the woman were to become aware it would probably destroy the relationship and she wasn't willing or wanting to accept responsibility for triat (Betsy).

Some women come into therapy cleariy opposed to feminism and "women's liberation," and the therapist knows her values are very different from theirs. Often stating her values and her awareness of how they differ from those of her clients has raised consciousriess and avoided game-playing between them; but one therapist gave an example of a situation where this had not worked. When the client "came in saying she believed in God and husband and her role in obeying and living for and living out the values of her chosen man:" the therapist tried clearly stating how her values were different from her client's but that she would try not to influence the client, beyond her wishes. The therapist's perception is that the client was influenced by her nonethe?ess, "and then resented me for influencing her because it precipitated some incense conflicts she wasn't able to handle" (Joyce). Two therapists reported feeling very impatient with women in destructive relationships with men. Ore explained that when she sees verbal or physical destruction of a woilan by her nusband and yet the woman still wants to stay in the marriage, she finds it hard to moderate her own desire to tell the woman she should get out. She is aware of not 
understanding "the glue of marriage" and questioning whether marriage is even desirable for people.

I think maybe my feminism, my personal sense of things, does get in the way of my therapy. It's real hard for me to support a wonan who wants a marriage that doesn't make any sense in my terms.

(Elien)

When that happens, she refers the client eisewhere.

One of these therapists also said that she is struggling currently to integrate her socialism as well as her feminism into her therapy. She gave an example of a dilema she faced when a client who had been working in therapy on speaking her mind and disagreeing with people joined a food cocperative and objected to distributing the group's fliers which said, "Down with Capitalism." As a socialist, this therapist felt in a bind.

I felt like as a socialist, I didn't want to just let that go. I wanted to talk about where I'm at. Yet in the work I'm doing with her, for herself, it's importart for her to disagree. I felt like in her own therapy, she should disagree, and for me to try to brainwash her to what I think in some ways might run against her own therapy.

(Karen)

\section{Structure}

Feminist therapists were nexi asked whether they had made charges in the structlira! aspects of their therapy that had to do with their faminism. Particular aspects probed for were ways of handling fees, structure of the first session, attitude toward clients shopping for a therapist, and contracts around goals and duration of therapy. This was an area where in retrospect probing to determine if changes had to do with feminism or with something else was particularly crucial, and was at times bypassed. Therefore, the analysis of responses to this quastion is more descriptive of what fominist therapists actuaily do 
around structural issues than why they do it. Mosi negotiate fees and some encourage client "shopping" for a therapist and ideritify themselves during the first contact. In general, however, it seems that they do not see changes in the structural aspects of therapy as an important part of feminist therapy.

Fees. Of those women who handled fees and indicated how they did so, all spoke of incorporating some form of fee negotiation or exchange of labor except one woman who does her therapy as a "natura? helper" and doesn't charge at all. They speak of not wanting to charge anyone any more than she can pay, and yet of their own need to establish some minimum fee. Some are fairly structured in how they scale their fees; others seem to let the client determine her own fee. One therapist makes it a practice to see one or two women in crisis situations for free or an exchange of labor. Several women indicated that this commitment to negotiate or income-adjust fees has more to do with their politics than with their feminism.

I don't know if it's feminist, [but] I have a political commitment to having a very large sliding scale, anywhere from $\$ 10$ to $\$ 35$. But that's not something I do just for women-.. [the feel always depends on people's income. I saw one patient who was referred by the biomen's Center and she got very very angry' with me for charging her $\$ 30$.. . She felt that as a woman, I should understand where women are coming from. I felt absolutely no sympathy for that at all. I felt that she had money and I dian't see why I should charge her a very lowifee, just because she was female.

(BEth)

One therapist's feminist reasons for negotiating fees are connected

with her anti-psychiatric and anti-capitalistic orientations.

For sure, women have been less able to afford paying psychiatrist's fees than men. One of the things women need to becoine separated from their dependency on men is some economic power, and if I can give them support fron a feminist position it would be a terrible contradiction to keep that 
support away from then because they can't afford to pay me. - . It's a combination of the anti-capitaijsm and therefore the anti-traditional-psychiatry bias, as well as a pro-feminist bias.

(Teri)

Seven women talked about the issues involved in fees for them. Three reported that because of their socialism they don't be ijeve that anyone should be charged for therapy and yet their agency demands they charge or they need to do so in order to survive. On the other hand, one therapist feels that "you have to put your money where your mouth $i s$ " and has fourd that "people who don't put in something also don't invest their energy" (Cheryl). Another reports that she used to fee? that women therapists should work with their sisters for free or for very low fees because women cijenis so often have less money. Other womer therapists in her group insisted that women oughi to take therapy as seriously as men do and pay for it in the same way that men do. At the same time, the group grappled with how to charge women receiving alimony without maintaining their deperidency on their ex-husbands. Over time, she has come to feel that "working for free is really counting yourse if as less valuable" and so doesn't do that ariymore, although she does negotiate fees (Betsy). One therapist was concerned that fees might be reinforcing in her clients the very powerlessness that she's trying through therapy to get them to overcome. "That's cailed insanity. I don't want to create an insane system when I do psychotherapy" (Marsha). Final!y, one woman said that she is undecided about whether she should negotiate fees beciuse on the one hand "people play such games around money" and yet she believes that for women who really need and want help and don't have the money to pay, holding to a rigid fee would be unfair (Peg). 
First Session. Interviewees were asked if they did anything the first time they saw someone that they felt was feminist, probing at times for whether or not they made it a point to introduce themselves, explaining their values and biases, the way they did therapy, or their expectations of a client. Generally, things these feminist therapists may do during the first session is find out what has brought the client in and about past experiences in therapy, establish a contract for the length and perhaps goals of the therapy, specify their expectations of the client, describe or demonstrate the kind of therapy they do, and provide an cpportunity for the client to ask any questions of them she may have. Different therapists, of course, do some of these and not others. Asking a woman for a "herstory" of her experiences in theracy has a feminist rationale for one therapist because she is particulariy interested in knowing if her clients have had any negative experiences (including sexual) with other therapists, especially males, as well as finding out the client's expectations for therapy (Holly). Three begin to establish goal-oriented contracts at this time as well, but this seems to have more to do with their training than with their feminism. Only three feminist therapists make it a point to say during the first contact that they are feminists and that that's important to them. As one woman explained when answering what she did with her feminism in therapy, identifying herself immediately as a feminist means that her clients often then ask what she means by t!at, and the actual process of defining her value system is an important part of her feminist therapy (Alice). One therapist explained her goals for the first session as incorporating this introduction of herself, her expectations, and 
her method of doing therapy.

When I first meet someone, I try to say something about who I am, what I believe or expect. I say to them that I'in interested in whatever they can tel! me about what they want or expect. I' $m$ interested in answering whatever questions they have or telling them something of my philosophy to whatever extent they want that. [I tell them] that I expect to explain what I'm doing, expect rot to be laying something on them that they dor't want. I go over those kinds of things pretty carefully... . I try to communicate in the beginning that I'm going to respect their choices and their decisions, in whatever area.

(joyce)

Four feminist therapists said that they don't annource themseives imnediately as feminists. Sometines this is because they work in an agency setting in which they feel it is not relevant, because people who come to them aiready know they are feminists, or because it's not how they prinarily define themselves.

Shopping. Six women indicated that they encourage their clients to "shop around" for a therapist or that they at least encourage them to ask any questions they may need or want to know about the therapist. or the therapy process. One therapist who supports clients in shopping around for a therapist doesn't charge for the first session, which she describes as much more like a mutual interview than her regular therapy. They explain that they believe in client shopping even though it is sometimes difficult or threatening to them. For one therapist, accepting this idea has come out of her realization that she isn't going to be the "right" therapist for all people, and she encourages prospective clients to trust their own feelings in choosing a therapist.

I used to think I should really be appropriate for anybody. Now I'm at the point where I don' $i$ need any reasons why that isn't so, but I just am willing to go along with the feeling that the two people have about whether they're comfortable with each other or not. As much as I can try to let somebody get a feeling of the the first time, I really encourage them to rely 
on their ow: fee? ings about that. [If] sonebody who's shopping around : . . is supported [to do that], . . to go on their own hunches,. . . that is a very inportant thing that happens [out of the shopping], . . . something that women have not been encouraged to do. That's a feminist element to the shopping around that is different than the approach of traditional therapy.

(Nancy)

Giving people who ask her questions about how her groups operate "strokes for being inquisitive" is something another therapist does to support shopping. If people seem to need more encouragenent, she explains to them:

"I think it's fine that you ask these questions. There are a lot of bad shrinks around here and it's good that you' re asking me. I'm glad to answer any questions you have, and I think probably the best way to find out how I work is to come to a group and see what it feels like."

(Teri)

Encouraging shopping has to do with feminism for her because she sees it as a way for people, and particularly women who have been most oppressed by traditional psychiatry, to find therapists who will not oppress them. Finally, one therapist so strongly encourages client shopping because of the "horror stories" she's heard that if clients say they want to see her at the end of the first session without questioning her, she demands that they do so and trains them in how to do it.

[Jf] toward the end of the [first] session [c]ients] say, "Look, I want to see you in therapy," I stop them. I won't let them do that. I say, "What questions do you want to ask me. What do you want to know about me?" . . I've gotten some heavy-duty questions. I aiso get vonen who say, "Nothing." And I won't $t$ let them get away with it. I riake them hang in there. I say, "No. That's not good enough for me. You want to give me $20,25,30$ dollars an hour and you don't have anything you want to know?! You're willing just to give that money away to somebody vou don' $t \mathrm{know}$... anything [about] except that I'm a good listener and miake a few pertinent observations."

For women who have decided not to come into therapy with me, . . I give then instructions about interviewing the [next] therapist, and I tell them, "I want you to do it better with the next one than you did with me. You ask her some of these things. You find out. Some therapists will be willing to tell 
you on the phone. Some won't. And take into consideration not a!l therapists operate slike. You could get a real good one who [for example] doesri't want to talk about sexua? orientation. So you have to decide ahead of time how much that matters to you to know." . . . I say things that are geared to heip then take what they want into consideration and assertively go after it.

(Alice)

Diagnosis

Feminist therapists were asked, "How do you see diagnosis?" If they utilized any form of diagnosis, they were asked if they shared their diagnosis or not. ${ }^{9}$ Twelve of the 17 feminist therapists responding did not like diagnosis (or traditional labeling), but some found it heipful very occasionally or used another model (i.e., Transactional Analysis). Two thought it could be heipful, and three feit diagnosis was useiess and/or irrelevant. of the eight feminist therapists asked if they shared their diagnoses (from whatever theoretical orientation), four said that they did, explaining that it was a way of respecting the client, three that they did so carefully or partialiy, and one that she didn't share. The two feminist therapists with a positive attitude toward diagnosis felt that it was helpfui in that it provided some sort of "handle" for them in working with a client that they would not otherwise have. "It gives you a little bit of a shorthand or a quicker way of knowing some of the things that inight be true for then. You test it out somewhat, but it gives you a quicker

9 However, the real objoctive of this question was to elicit indirectly attitudes toward differing therapeutic theoretical orientations. Although sone feminist therapists discussed this issue at various points in the interview (see Dther Therapeutic issues), perhaps asking feminist therapists to compare their own and other theoretical orientations, particuiaily in reiation to feminisn, would have been more direct and reievant. 
direction of where to $\mathrm{gC}^{\prime \prime}$ (Nancy).

Twelve therapists were generally critical of diagnosis, at least in the traditional sense, calling it "jargory," "a bumner," "a 'should" in my life," but still utilized it in some way or some form. Seven described themseives as genera!ly opposed to diagnosis and labeling but indicated very occasicnal instances in which they thought diagnosis could be useful to them, such as in consultatiors with a psychiatrist, in working with very severeiy disturbed people, or in making referrals for welfare. Three used a Transactional Analysis model of diagnosis instead. One therapist explained that while her basic position is against diagnosis: she worries at times that because she doesn't have formal diagnostic training, she may be missing some things. On the other hand, she wonders if those things others say they find by labeling she is already aware of, just by utilizing her intuition.

I also feel you can work from. . intuition. This woman in my case study group said, "If I had been able to kraw she was a borderline, I would have been gentler with her." My thought is, "We11, perhaps I would have had the intuition to be gentler without knowing she was a borderline." Maybe I wouldn't have but it's a possibility.

(Karen)

Three therapists took strong anti-diagnostic positions. One said that her diagnosis could only be based on her reality, on "one person's head and how they see the worid. . . But somebody else could see things compleiely differently" (Diane). One described diagnoses as "totally useless. They don't mean anything. They're lies" (Teri). A third said she sâw diagnosis as "totally irrelevant.. I think it's a bunch of crap, a waste of my time." She said, however, that when people come to her she does make an "intuitive evaluation" of "how 
strong they are, how weak they are . . . , how together they are," at that point in time (Marsha).

Working with Lesbian and Radical Feminist Clients

Feminist therapists were asked either, "Can a woman (therapist) who's straight work with women (clierts) who are gay?" or "Can you work with gay women if you're not gay?" This question was designed to elicit attitudes about feminist therapy with lesbian clients, in particular to determine if they saw a difference in sexual orientation between therapist and client to be an issue in feminist therapy. Of the 17 respondents, four said they thought a straight therapist could work with a gay client, ter said she could on certain issues or for certain clients, two said they were unsure at this point, and two feit that a lesbian therapist would be better for a lesbian client. 10 In giving an example of a time when it was hard for them to incorporate their feninisn into their therapy, five feminist therapists discussed their difficulty in working with women who found in their feminism or iesbianism reasons to be critical of or remove themselves from the therapy process.

of the four women who said they thought a straight therapist could work with gay clients, one, a lesbian herself, said that in her experience, the question was more whether the gay woinan would be wiiling to work with the straight therapist, explaining that it is gay women who are often "prejudiced" against therapy done by any therapist who is not a iesbian herself.

MAnalysis of the data from the questionnaires indicates that 11 percont of the feminist therapists in the population focus on iesbian women in their therapy. 
Ten femirist therapists said they thought a straight therapist could work with gay women, depending on certain things. Five said that it depended on whether or not the therapist had worked through her own feeings about sexuality and whether she saw lesbianism as a viable positive alternative that was truly acceptable to her on all levels. The idea of whether or not a straight therapist couid work with a gay woman depended for five therapists on the client's reasons for coming to therapy or whether the client's homosexuality was still at issue for her. Several said that arourd certain issues, such as assertive training, comunication skills, or determining what she wants for nerself, they thought a difference in sexual orientation betweer therapist and client didn't make any difference. However, around certain issues, particularly when a client is dealing with her homosexuality itself (i.e., around "coming out"), they expressed more hesitation or felt that a gay client seeing a gay therapist would be more helpful. One therapist explained that she had been seeing one gay client who came to her initially as a straight therapist because this client had accepted the idea that straight women were better than gay women. Through this therapist's work with her as a feminist therapist, through the emphasis on minimizing the power differentiai between them, this client began to see straight women as not so perfect after all and ultimate?y left to work with a gay therapist, which this therapist saw as a positive step. She concluded:

I fee 7 like I can work with gay women. I don't think it is the same, and I think it depends on what the person wants, what the struggles are. Like some mothers might wart to see a therapist who's a mother, and for some it might not be that relevant at that point. So for this woman it was very important for her to make that miove.

(Karen) 
Three therapists said they felt that they could work with gay clients as stroight therapists, but it depended on what the cliert felt about it and if she did not feel she could work with a therapist who was rot gay, they would respect that. Two therapist's in this group said they were aware that there was a position among some gay women that a straight woman shouldn ${ }^{3} t$ do therapy with a gay woman. One said she had recently read an article which argued that a therapist saying, "Whatever your sexuality is ail right with me," was liberalism and that a therapist needed to take a starce. This therapist disagreed, saying, "I don't buy that. That's carrying it too far. . . . Nobody's hâd identical experiences with everybody else, so if that's the criteria for working with someone, then we're ail in troublei (Betsy).

Two therapists said they were unsure if a straight therapist could work with a gay client. For one, a straight therapist, this had to do with her lack of enough exposure to gay women to know if there would be any problems $(\mathrm{Peg})$. The second therapist who was unsure was coning from the opposite position. As a lesbian, she is feeling ivicreasingly separated fron women who are not gay. She sees around her examples of straight women oppressing other women (i.e.. in contributing to the defeat of the Equal Rights Amendment in some states) and thinks that would go on in therapy as weli. She believes gay women are much more comnitted to women than straight women. However, at this point in time she is still unsure about her position on this issue (Marsha).

Finally, two therapists seemed to feel that it would be better for lesbian clients if they went to a lesbian therajist. One heterosexual therapist has found that many of the gay women she has scen were so 
worried about her position on sexuality and felt so frightened in the groups that her therapy with them was fairly unsuccessful. Therefore, she feels that for "women who are gay in a long-term sense and have gone through all that paranoia and niess for a long time, it would be better to have someone who's gay to work with." However, for women who are coning out, she feels that as a straight therapist, she has been able to be "a kind of bridge, saying, 'It's OK; it's fine with me that you do' and that's been important and good" (Ellen). Lastly, one therapist expiained her own background in struggling with her commitment to women and her sexual identity and felt that because of that she had a great deal of awareness that was more than intellectual as a heterosexual woman about homosexual women. However, she still feit that all that could not bring her as close to the experience of lesbianism as actually living it (Sue). Difficulties with Feminists and/or Lesbians. Five feminist therapists, when answering the question of when it had been hard for them to incorporate feminism and therapy, spoke about their difficulties with some other feminists who have taken aspects of the feminist value- and belief-systems and used them to justify not confronting themselves or changing in therapy. ${ }^{11}$ They explain that often, these are women who diagnostically would be called borderline paranoids or schizophrenics

${ }^{11}$ Several viomen also mentioned in this coniext that they like working with women who are in the process of developing a femirist consciousress, who don't fit the traditional feminine stereotypes, or who are feminists already. They point to the receptivity of these women to therapy and to a feminist corisciousness, and their ability and desire to have the therapy relationship be inore egalitarian and less traditiona?. Because they are already questioning, reminist therapists find therapy with these women exciting. "The women who are not remirists are more boring to me and harder to work with" (HOl?y). 
and have integrated the mind-set and beliefs of the women's movement, into their own distorted system. When this happens, the wornan then either uses the feminism against herself or against, the therapist. In the former exampie, a therapist expiained that when she tried "to say something that would be having compassion for herself, she would come up with a good reasen why she shouldn't and couch it in feminist terms" (Karen). In the latter instance, a therapist reported that trying to work with such a woman "drives me bananas."

Ordinarily if it was somebody who wasn't psychotic, there's a lot of places to support and to help a woman see that, "Hey, it's not just you." That [support] is a major part of femirist therapy .. . [but supporting it for these women supports their whole system] and that's reai hard [for me] to deal with.

(Nancy)

One therapist (who is herseif a lesbian) finds that some of her most frustrating clients have been lesbians, for similar reasons:

Some of my most frustrating clients, the ones I've really felt like throwing up my harids with, have been gay women. Because of their victim thing and their contimuaily stroking themselves with rage about men. I've had a couple of radical lesbians who say [angrify, accusatorily], "How cone she should forgive her father!?" . . . They're frustrating. They have a big feminist [radical lesbian] Parent that says, "Be Strong. Don't Relate to Men."

(Holly)

Two women indicated that their belief systems often made it hard for certain feminists or lesbians to hear them or accept directions they felt the therapy needed to go in. A Jungian therapist senses that because of Berkeley's politicization, many of the things she says are heard as reactionary statements about womeri. While she doesn't think they are, she finds it hardest to work with women who "feel very bristly" when she tries to expiain the loss she sees in their developing just the masculine sides of themselves. Another therapist says that her ideas 
about the develoument of a person's sexual orientation lead her to believe that some of a lesbian's yearning for contact with a wonan comes from a lack of good modeling from her own mother. In doing therapy with these women, she sees them as needing to explore their relationships with their mothers, and has "a feeling that's probably not too palatable to a lot of peop?e who realiy den't want to think about mother at all" (Chery?). This therapist also reported that she found it hard to work with some of the younger clients who were coming to her recently. She describes them as bright, high-energy, "go-getting" women, and yet finds that in part because of that they don't want to make the commitment to therapy necessary to develop trust. They "come in and then move out," disappointed and perhaps angry, hurting the group by their sudden leaving and frustrating her (Cheryl).

\section{Power Issues}

Since the issue of power was discussed in the literature both in criticisms of traditional therapy and as an important aspect of feminist therapy, interviavees were asked, "Do you think about power issues in the work that you do?" If they seemed puzzled or talked exclusively about personal power (as used in Gestalt), they were asked more specifically, "Do you think that in your relationship with your clients there is a power differential or do you see it as a relationship between equals?" Over 75 percent (14 of 19) of those interviewed believed that there was an inherent power differential in therapy, a structured institutionalized inequality in the therapeutic reiationship in which the therapist was dominant and the client subordinate. Among those who perceived a power differential to exist, there were difierences in how they incorporated that belief. 
Therapy as Inherent Power Differential. Anong those who believed that a power differential was inherent in the therapeutic relationstip, some viewed this inequality as based on the therapist's leadership or limit-setting role and therefore her responsibility for and position of ultimate control of the therapy situation.

They're coming into my group, ostensibly anyway, on my terms. . . It's my tape recorder. By and large I'm the one that turns it on and turns it off. I say, "We'll start now" and "I'd like to take a break now." Those are ail power things. (Pat́)

Anthough one therapist felt she had skills in therapy while her slients had skills in other areas, others spoke of the differential in skilis between them and their clients.

I think that there's probably always a power imbalance because of the rature of the contract. They're ca!ling me for help. They're not calling a friend for help. If I call a friend for help [or do it myself], I've got a different kind of power thing going than if I call a professional person for he?p of any kind . . even . . a professional mover or fioor layer. By nature of the contract, I've already got an imbalance in power going. I'm going to see someone that I fee? has more expertise in some area or another than $i$ do. . . . I assume that people who come to me are... missing some information. . They don't know how to get more in touch with what's going on inside them. So I'm going to be a guide for them, to help them get through that. (Lesile)

Although this experience or skill differential dces not mean in their eyes that they see themsalves as doctors to sick patients or gurus to the unenlightened, nonetheless it does happen that their clients expect them and need them to remain in a role apart from friendship and depend on them in a way that they do not depend on their clients.

It just is inherently an unequal relationship. They depend on me in a way that. I don't depend on them. I think of it mainly in a parental mode?. . . In terms of what happens in the hour and in terms of what hapiens in therapy--how often we meet, how long we meet, whether or not they're in a group... , how. involved they are--I'71 never insist on things... . but the inevitable thing that happens is that they feel very irvested 
in me. I fee? investad in them but I don't feel dependent on them. When I'rin a patient it's the reverse. You feel neery and helpless and less independent, and sn you fee? ?ess powerful, and in some ways you are less powerfur.

(Beth)

Among the responses of those who saw a power differential to exist, four ways of incorporating that belief emerged, with sonic taking one position clearly and others several. The position taken least frequently was the acknowledgment of the existence of a power differential, coupled with the belief that its existence didn't reaily impact on the therapy. In other words, some feminist therapists felt that having a differential in therapy skills or in control of the sessions could remain context7 imited.

A second position (held by nine of the 15 viewing therapy as a power imbalance) was acknowiedgmerit of the power differential in the therapeutic relationship as a given, and an attempt to make the relationship as equal as possible within the context of that basic inequality.

A third position among those who viewed a power imbalance as existing was to stress the acknowiedgment itself of the issue of power in therapy and the potentials for power abuse by the therapist, thereby moderating the impact it has when denied.

There definitely is a power difference. it's liberal to assume that there's not... I think it's important to recognize that and then instead of playing into it to recognize it and try to work through that. (Karen)

Generally, this means being attuned to power issues between the therepist. and the client, to the ways a therapist can use her power to hurt or to control, to the dangers and pulls toward power abuse. (Specific examples of the ways they deal with power issues are discussed in Section III, under Descriptions of Feminist Therapy.) 
Both the second and third positions above see power as a negative force, at least insofar as it functions in mantaining imbalances between people and has the potential for abuse. A third group perceives power in a much less negative fashion, as neutral or as having both the poteritial for good and for i11. Those adhering to this position speak of attempting to use their power, gained in part because of the power differential, for the good of their clienis. One speaks of her power as a "therapeutic form as well as a philosophical stance" (Betsy), at times varying it depending on the dynamics of the therapy process (i.e., if the client is very dependent and gives away power, deciding with some not to take any and with some to take al? that is given). Others use their power to provide an environment that is safe enough for clients to feel able to question and grow.

I think power in itself is neutral and can be used well or used badly. One of the things that people are coming into the group to do is to be in a place where someone's who's safe and friendly and has thieir well-being at heart will take care of the [structural] things. . . Part of the therapeutic process is that a person looks for and hopefully finds someone who is powerful enough to offset their script pattern. (Pat)

One feminist therapist speaks here of utilizing her power to elicit from people their power so they no ionger need hers. Two women find that as powerful figures, they are used by clients and trainees as models of women who are assertive, potent, self-respecting, and feel and use their own power for positive ends. One therapist feels that because she is powerful in the therapeutic relationship, she has the potency to clarify "crazy" thinkirg in ways that aren't judgmental or hurtfur, a new experience for women.

Most women hoven't gotten feedback from peop?e about parts of them that they don' $t$ like, except when the feedback has been devastating or judgmental or putdown or religious. And for 
them to see someone really be atle to do that makes them feel differently about themselves. . . That's the power I'm aware of, the power to heip a person see themselves in a hopeful helpfu? way and to incorporate the power [that I] mode?.

(Alice)

However, the power "for good" is equal to the power "for bad," and at times the latter mistakenly gets used. "What really scares me is when I've made mistakes and have had a hurtful outcome. . . . [It] worries me that somebody should have that kind of influence and power" (Alice). Some of the feminist therapists who saw a power imbalance existing in therapy aiso spoke of its existence in other social contexts as well, and felt that their belief in the power-structured nature of relationships and the roles of dominance and submission inherent in them was an added awareness they brought to therapy. In their analysis and in the therapeutic process, they are sensitive to issues of power between people in their groups and between their clients and others in the society. One therapist explained that she believes most people who come to therapy do so in part out of their unhappiriess in power-structured relationships (Teri). Another said:

I think a lot of peopie either don't know [aboui] or are scared to touch ... the area of . . power balance between people and in situations. . . I beijeve that there's such a thing as "I'm OK, You're OK." [But] I also believe that some people have more power than others, and it's damn hard to get there when somebody's either got more money or more prestige or a higher job or is simply physicaliy larger. To not be aware of power issues can lead to people's being confused, with the therapist saying. "This is the way it is and this is the way it works and let me diagram it for you" and the person. knowing it in their gut that "it ain't that way." (Pat)

Therapy as Relationship between Equals. Five women did not feel that

a power differential was inherent in the therapeutic relationship. As they saw it, the relationship between therapist and client could be one 
of equals or, for one woman, one in which the client had most of the power (Ann). If a client experiences a serise of poweriezsness, that has more to do with ways in which clients give away their power to the therapist or the process of coming to someone for heip.

One therapist strongly disagreed with "the more radical feminist. therapists" who feel that therapy is one more destructive perpetuation of situations where a woman is "one down" and who therefore focus intensely on attempting to arrive at an equality in the power balance. She feels that it is common for people entering therapy to feel vuinerable, to not feel powerful; but sne sees that powerlessness as a function of the lack of security and lack of power in all areas of their lives which brings them to therapy rather than anything done "to" them by the structure of the therapeutic relationship. While she attempts to acknowledge "the intrinsic poweriessness that can be there when [people] begin therapy," that powerlessness does not make her more powerful. Her power remains constant throughout the process of therapy, while the clients' sense of their power increases as therapy progresses until they no longer feel powerless (Nancy). A power differential does not exist, one therapist explained, because helping and needing help are interchangeable.

These people come to me feeling like they're screwed up, like I'mi going to help them. I say, "That's ridiculous. You only feel screwed up because people tell you you're screwed up and you've come to this role." I couid be where they are and they could be where $I \mathrm{am}$, and we have been in these different places with each other. . . I realiy don't fee; I have any power. It's. . in all of us. It's a matter of how much we are willing to let it out.

(Diane)

For one therapist, confronting the role expectations and stereotypes her clients place on her has invoived struggle and risk, but she believes doing so is the way to achieve a real equality betwcen therapist and client. 
I think that in the past I have been very uncomfortable with somebody putting me "one $u p "$. . . ; but i have a tendency to pretend that they weren "t doing it and so not be real explicit and say very directly, "I want to be equal with you and this is how I'm going to be equal. . . This is how I'n not in that role [you put me in]. . . I don't see myseif as a person who tells you what to do or gives you advice. If you want my opinion and we can agree on that, [then] I might give you my opinion."

(Joyce)

\section{Answering Client Questions and Self-Disclosure}

Two consecutive questions in the interview asked feminist therapists if they answered client questions ard if they talked about theinselves during therapy (self-disclosure, self-sharing). If they did, they were generally asked if they thought doing so had anything to do with their feminism. Most said they answered questions and self-disclosed, although many qualified the instances when they would do so, saying it depended on the client, the question, or the appropriateness of the situation. Many said that answering client questions and self-disclosing had to do with their feminisin, but some said that it had more to do with their training.

Arswering Client questions. A belief in answering client questions was posited against the more traditional therapeutic ard Gestait views. In the traditiona? framework it is important for a therapist to understand questions within the context of the client's pathology and to be somewhat removed from the client in order to be effective. Gestalt sees questions as projections best cealt with by "turning them around" and having the client ie the therapist and answer in fantasy. Of the 18 feminist therapists interviewed, one said that she generally did turn questions around. The others said that they answered questions, five as a general rule and 12 depending on the question, the person, or the situation. 
Those seven who said that whetrer or not they answered a cijent question depended on the question being asked differentiated between "straight" questions which come (in TA language) from the adult ego state and are based on the client's legitinate desire to know more abcut them, their work, their opinion, and other questions which they hear as disguised statements or as the client abdicating her own pover in asking them what she shouid do. They ariswer the former but not the latter. However, one therapist said that if a client asked a question like, "What do you thirik I should do now?" and she answered by asking, as more traditional therapists do, "What do you want to do?" then she vould be discounting the client. She tries instead to deal with the process of power abandonment.

What I usually say is, "Look, I have some ideas about what would be good for you, but I think it would be better for you to ariswer the question yourself. I think you'd feel better. I think it's more powerrul for you to ariswer it yo:ırself. I wani to know what you think you shouid do. And I'li fill in the holes. But do your share of the work." (Teri)

Sometimes she also uses the group to answer questions rather than aikays hoiding that power herseif.

Those who said that whether or not they answered a client question depended on the person asking differentiated between clients who repeatedly asked questions to get assurance or advice or perpetuate a power imbalance by placing the therapist in a "status position" and clients who were genuinely requesting information as one equal to another, answering the latter but not the former. One therapist gave an example of a woman she was seeing who asked her a number of questions because she wanted her therapist to be another human being and not a "vague shrink," and she said she answered all those questions. She is aiso 
particularly willing to answer questions asked by women beginning to make changes in themselves as women who want to know if she has ever gone through what they are experiencing. However, she finds she answers these questions more with general statements of support than with specific information about her life.

Several said that whether they answered questions depended on the therapy process itself. When a woman comes in initially to see one therapist, she answers as niany questions as she can and encourages the client to ask the next time others she may have forgotten. However, once therapy begins, she searches out more what's going on for the client in asking (Nancy).

Among those five women who generally answered client questions, doing so has to do with their belief in being more direct and "straight" with clients, their desire to "not play games." One therapist in this group called not answering questions "a cop-out" on the part of the therapist, and feels that when therapists aren't open to clients, the client puts energy into "psyching" the therapist out rather than into dealing with her own problems. Similarly, another therapist said that the model of not answering questions is "there to protect the therapist, to keep you behind a wall" (Beth).

of the 12 women asked whether their answering client questions had to do with their feminism, four said that it did; four that it had to do with power and through the power with feminism; two that it didn't have to do with feminism but with their training; and one that it just had to do with being "straight." Those who saw answering client questions as having to do with feminism explained that the connection 
was their focus on the importance of shared womanness and shared humanness between then and their clients. One woman said she felt feminism had also heiped her not always answer questions because it supported her in "not aiways being rice" and asserting her right to her own personidi coundaries, barriers and defenses. For four therapists, answering client questions had to do with not wanting to becone more of a power figure in the therapy relationship than was already inherent in their role or to further mystify the therapy process. They believe that clients have certain "rights" in the therapeutic relationship, one of which is to have their questions answered.

Often I'll answer questions that I wish hadn't been asked simply because $i$ think that's fair. An example [was when] i was interviewing someone who wanted to be in a self-awareness group here. After I'd asked him a number of questions, he . . started asking me questions. In a sense, what he was doing was reversing the process. His questions were fair. I was a little uncomfortable because people coming in to be interviewed by me don't usually ask me questions; but I thought, "turnabout's fair play." I don't like a power relationship in which I can ask. all the questions and nobody can ask me anything. (Fat)

One therapist added that she saw answering clients 'questions as giving her clients permission to be inquisitive, to take power over their environment (Teri).

Self-Disclosure. "Talking about yourself," self-disclosure or selfsharing were explained here as different from value-sharing or opinionstating (discussed at the beginning of this section under vaiues and Directiveness). Self-disciosure was presented as a more personal sharing, often having to do with one's own experiences in areas similar to. those the client is presenting. Of the 19 feminist therapists interviewed, 11 said that they did self-disciose, six that they did so only when appropriate, and two that they did not or did so orily very selectively. 
Those who said trey self-disclosed and focused in their answer on their reasons for doing so rather than qualifications for when they would not were scored anong the 11 who self-disclosed. Self-disclosure often has to do with a willingress and desire to get involved, and feminist. therapists see themselves as having this a much greater priority ihan "traditional" therapists do. Said one therapist, "I very muci believe in self-disclosure and so I do a lot of that "(Sue).

The things I talk about are very much related to me and how I'm living my life... I'm not spieling out a philosophy that I've learned in order to fit their situation. I'm coming from me, and what I feel the strongest. I get emotionally involved. I don't stay aloof. I'm not afraid to care about someone and let them know that. I left [behind] all those rigidly defined structures and philosophies.

(Diarie)

Several made the distinction between self-disclosure, which they strongly believed in and did, and "working on myself," which they avoided.

In their resporises, they gave examples of the kinds of self-sharing they typically did and their rationales. Sometimes what they share has to do with times when they have had similar dilemmas or problems to those their client is presenting.

I'll share some things about myself, like if someone is working or a "Don': Be Close," and is stuck and all upset because they're stuck, I'll say, "We1l, I've been stuck on that one too," and share a particular therapy experience I've had. (Holly)

Another reason stressed by some for self-disclosure was a desire to demystify themselyes as therapists, to counter the image of themselves as people who "have it all together." For some, the things they share are often purposively tied to feminism. As they share their own experiences, they are aware they are also sharing ways in which feminism has had a positive impact on their lives. "I'll relate what my experience was. particularly around feminist things, how much better I feel as 
a woman and as a person now than I did back in that cther kind of life" (Peg). In part, they are consciously talking about themseives to mode? (as discussed in Section IIJ under Descriptions of Feminist Therapy). Several of these women also said that a dilemma for them at times was knowing how much or when to share, or sharing wher it was rot relevant. Orie woman said that she felt in a dilemma when a client would ask her to share with them as much as they shared with her, particularly because achieving a more equal therapeutic relationship was important to her.

Six womer said that they self-disclosed when appropriate, depending on the client, their relationship with the client, or other aspects of the therapeutic situation. What they shared and why they snared it were very similar to the examples given above. Hovever, they were more concerned about choosing the times when sharing was appropriate and not contra-indicated. They gave examples of clients who they feel would be unable to handle appropriately a knowledge of personal things about them and of instances in which they feel it is more important to "work the client through" a particular issue than to share their own experiences, no matter how experientially relevant. One woman explained that she shares "consciously," meaning that when she does so, she always has definite therapeutic ends in mind.

I'll sometimes talk about myself to model. I'll sometimes talk about myself, my intention being to build trust, to make contact. Within the therapeutic setiting, I do so in a very stylized manner. How I taik about myself with my friends is different than how $I$ do in a group. I'ri not willing to make myself vulnerable, the "if I tell you all about myself you'l? think I'm a rice person. . . I'in pretty choosy about what I disclose. I'm also willing to do it when I think it's goirg to be helpful.

(Pat)

Two women said that they stared themselves "very selectively" or "not on a regular basis," feelirg that talking about themselves was 
very often not relevant to their clients' lives and at times inplied that the therapist's way was the way their clients "should" be.

Sixteen of those 17 therapists who said they did self-disciose were asked if doing so had anything to do with their feminism. Eleven said that it did, particularly with issues of power and how that related to feminism, and five that their self-disclosure didn't have to do with feminism. As in the connections to feminisn of answering client questions, self-disclosure is done to break down the client's sense of isolation by knowing that her therapist, also a wornan, has had similar problems and struggles and to model changes in feminist directions that have been positive ones for the therapist. Self-disclosure often comes, it seems, out of a desire to demystify oneseli as a therapist, to diminish any power the client gives to the therapist in her role as being a person "better than, more together than" (Karen) the therapist really is as a person. As explained in Section III, this attempt to dininish the power imbalance was an aspect of feminist therapy mentioned by many feminist. therapists. In this context, one feminist therapist explained that her rationale for self-disclosure had to do with her attitudes toward power (connected with her feminism), her belief that clients do know what they need and what is best for them. So when one ciient told her that it had been very meaningful for her when his therapist shared things about her life during therapy, she has tried to remember to do that. Even though she's "not super-comfortabie with that all the tine," she says, "I try to go as far as I can to meet what each persor wants" (Beth). The five wornen who self-disclosed but didn't feei doing so had to do with feminism said that they knew other therapists who were not 
feminists, who also valued and saw the usefulness of se?f-disclosure. One said that selr-disclosure came out of the human potential movement (which she considers sexist) and criticized the women's movement for claiming that anything women did more easily--like self-sharing--was therefore "superior and wonderfui" (Teri). Another therapist said that she thought self-disclosure was "more connected with being straight" than with being feminist. Two Gestalt therapists said that for them, being self-disclosing hảs come not from feminism but from Gestait's emphasis on "being more authentically there and saying where you are" (Lesiie).

Therapy as Poitical or Apoititical

Respondents were asked, "Do you see what you do as political or apolitical?" If they wondered what "political" meant, they were encouraged to use their own definition and explain it. Of the 19 feminist therapists interviewed, 14 perceived their work (or part of their work, or the ramifications of their work) to be political rather than apolitical. 12

Therapy as Political. Among the 14 women who labeled their work political, 13 several major themes emerged. These include the rejection

120ne feninist therapist, a Dean of Women Students, differentiated between her direct counseling, which she calls "semi-apolitical, "and the work she does in coordinating programs for women and taaching Wonen's Studies, which is political (sue). Therefore, the political aspects of her work are included in the discussion of the political position, the courseling in the apolitical.

13 Interestingiy, although 14 femirist therapists considered their work political, when asked, "What do you thirk a person gets from you that she wouldn't get from soneone who wasn't a feminist therapist?" they did not discuss the political ramifications of their wark as one of the critical differentiations between feminist therapy and other therapies. 
of traditional (both eiectoral and activist) definitions of "political," the development of a new definition of what is political focusing on power and the interconrectedness of the personal and social realms: and the belief that all therapy is uitirateiy a political statenent. In the traditional sense of the poritica as ravirg to do with electoral politics or positions on national iscues, only one of these feminist therapists included that in her definition (Saliy). Others differentiated their definitions of "the political" both from that and from the more radical definitions of the political as having necessarily to do with organizing and demonstrating. Only one woman strongly stated that the goal of her therapy was involvement in feminism and thereby radical political action focused toward systematic change.

My ultimate goal as a feminist therapist is for [my clients] to get hooked up [with faminism] or become feminists themselves. If they become feminists themselves, they will love to be with other women, and wili support other women, and will be involved in women's groups, arid will try to furthor the women's cause, which is my goal--not an individual solution but a total change of the system. They would have to be involveci in something. . . I would certainly label that a very clear expectation.

(Marsha)

Others disagreed with this stance, saying that their goals and their definition of what is political are broader, perhaps but not necessarily including political activism.

Hopefully, part of what happens is a person feels her strength more and helps to build the muvement more, getting together with other women,. . . just not staying in ycur own little niche but going out and building something. . . I krow that there are some people who say that a woman isn't healthy unless she goes out. [I don't totally agree with that]. . . . What can be political can be broad. For a woman who's just in the home a lot,... going out and with a few other women organizing some kind of cooperative child care, that's political.

(Karen) 
Another therapist disagreed because of the contradictions in that stance with her humanistic belief in self-direction and individual autonomy.

Some other feminist theranists feel that their work with the client must terminate or culminate in the client.'s doing politica? activity. To me, that's a narrow-minded way of looking at it. That's destructive in the way that it puts out an alreadyformulated route for somebody to go, [while] the important part of [feminist therapy] is women in ail areas having rea? freedom of choice and living that out and assertirg themselves in whatever they're doing.

(Nancy)

Two other feminist therapists disagreed in the context of revolutionary strategy rather than the humanistic philosophy above. One woman explained that while she believed in "the revolution," she focused on the here and now.

People live here and now. Whatever social change that may be going on years from now . . , there is still getting up in the morning, deciding what you want to have for breakfast, what you're going to do after that and who you're going to be with. Uriappy, lonely, scrunched up pecple don't make good revolutions.

(Pat)

Another explains that there is always a place for artists as well as organizers, and therefore that she doesn't "lay heavy trips on people" like saying, "If you really have your shit together, you'd be out organizing" (Teri).

Those feminist therapists who saw their work as political gererally defined the political as having to do with power, often acknowledging that as their own or a new and non-traditional definition of what 'political' was.

Somewhere I've read that political is use of power... Everything i do [in therapy], in a sense, is use of power.

On the most basic level, politics has to do with power and the distribution of power. . . What goes on between people has a political effect, because it has a relationship to power and the distribution of power in relationships. (Teri) 
The themes of action and Feminist Humanism (see Section Ill, Descriptions of Feminist Therapy) are reiterated here: the beifef that women have power as individuals which they are not--but can be--in touch with, that they can and need to make their own decisions about their lives, and that awareness of oneself leads to change. They are saying that when a woman moves from a position where she feels powerless to a position where she feels powerful, that is a change not only in how she feeis about herself but in the poitical realm as well because it means women are now making decisions about their own lives and changing the distribution of power in relationships. At that point, these changes are not only personal changes but changes in the social process as well.

I get boggled when people try to separate personal change from social change, because I don't think you can separate the two. People are personally affected by social changes, and societies are affected by personal change.

(Pat)

This interconnectedness of the personal and social realms, the sense that the personal is political, was alluded to frequently in discussing the political nature of feminist therapy. One therapist made the distinction here between traditional definitions of the political which focus on goais and her definition which focuses on charges in process instead of changes in outcomes. She sees her therapy as process-centered and therefore political in a new way (Carol).

Several women added to the political dimersion of their work the idea of therapy as consciousness-raising about the connections between a woman's life experiences and the social (or political or economic) system. One woman commented that when she teaches (which she considers a part of her therapy), she does so from a definiteiy feminist stance and coes not even attempt to or care about presenting the anti-feminist 
position. She sees this ós taking à poitical position. Another therapist sees her therapy as correlated with and a statement of her politics. In addition to helping her clients become aware of the connections between their personal lives and the social system, she attempts to "turn people onto options" to those systemically sanctioned (and therefore power-restraining) ?ife-styles, and sees doing so as political because it impacts on people's powerlessness.

One of the reasons people feel power?ess is because they don't know what their options are. I think one of the roles of a radical psychiatrist or an advocate psychiatrist is to turn people on to their options. You don't have to live alone, isolated, in a studio apartment that costs 200 bucks a month and work in a straight job eight hours a day. You can get. together with other folks, live in a house together, share food, labor. (Teri)

She and another therapist both spoke of their own lives as political statements which they modeled in therapy. For one, it is choosing to work half-time, for the other it has to do with finding work to do that is meaningful to her and useful to others outside of the institutions of the "straight" culture, modeling "taking power in my life to feel good" (Teri). A third feminist therapist said that her iow fees designed to "give women a fair break in therapy:" her encouragement of people making changes in spite of the system, her lack of bias toward gay people, and her acceptance of a person's politics were all political statements (Holly).

Six women questioned whether anything as impactful as therapy could be apoliticail, believing that all therapy---whether done by a feminist therapist or a Freudian psychoanalyst--is political and that "no position is a position" (Karen). "It is not that we feminists are making it political--it has always been political" (Marcha). Aricng 
these therapists, even those who don't make explicit political statements or attempt to influence their clients towards feminismi feel that their politics comes through in their work.

I'm political in the sense that I'm conscious of political relationships. I'm conscious of power relationships that come up in some way or another, and have a position about them. I don't think I can avoid being political, really. J'mi political in... how I work with people. I'm! political in what kinds of issues I talk about with people I work with. I'm taking à political position in working part-time and saying I believe in it.

(Joyce)

Therapy as Apolitical. Five of those six women who defined their work (or, for ore woman, part of $i t$ ) as apolitical said that they labeled themselves in this way because they focused on individuals and ridn't view as their goa effecting change in the structure or functions of the social system. One explained that she does very long-term therapy with clients, often twice a week and therefore works with oniy 15 people. She doesn't see how doing that "is going to change the society [or] make much difference in the world" (Beth). This therapist was formerly very active in radicai politics, especially the anti-war movenient, and her apolitical stance at this time has to do with feeling that although she "drained" herseif doing so, what she did there ultimately didn't do any good. At this point, she feels comfortable being apolitical because she doesn't see any political options that she can believe in. Although many of the womeri another feminist. therapist sees are feminists who consider her work political, she doesn't because those who see rer who aren't feminists aiready "can leave without having one bit of change in that sense" (Ellen). A third woman sees mostly "middle-class middle-inconie suburban women who are not really ready to jump on a bandwagon" and she doesn't feel an obligation to bring them to awareness until they are 
ready to make the connections themselves (Peg). Finally, one woman categorized here as apolitical actually defines her work as spiritual and therefore removed from the political/apolitical dichotoiny.

"Political" I usually thinik of in terms of activist and I'm not an activist except in how I live my life. . . Political means to me group-collective-working and I don't feel that way. What I feel I'm doing is sharing how I feel about things-my spirit.

(Diane)

Issue of Losing Potency by Incorporating Feminism

Feminist therapists were asked if they ever felt at times that. things they believed were important to do in incorporating their feminism into their therapy meant that they did things that their clierits weren't ready for or diluted the therapeutic potency they might have if, for example, they did not answer questions or remained more unknown. In other words, they were asked if there were for them conflicts between being a feminist therapist and being a therapist. In answering, three basic responses emerged among the 17 feminist therapists interviewed on this question. Three said that this was a dilemma for them that they had not yet resolved; five said that they felt even if they were less potent at one moment or said something a client was not ready to hear, their having done so would ultimately be an asset to the therapy relationship; and nine, the majority, said that the readiness of the client and their assessment of the therapeutic situation at that point in time governed what they did.

Concern with Losing Potency. The three therapists who said this was a current issue for them explained their dilemmas. One said that she wondered whether there were times that her feminist perspective on a woman's citcation might be getting in the way of her really being 
able to see how disturbed a person was. She also compares her work with that of her husband, who self-discloses much lass than she does and maintains more control, and wonders if he is more effective or orily more egocentric.

As I watch my husband work, for instance, he's strictly in control and reflects back all kinds of stuff like that... Sometimes I get pissed about that. Sometimes I see that as an ego trip. And yet it's very effective and it's probably more therapeutic too.

(Chery 1)

A second woman said that she had been thinking a great deal recently about the issue of potericy, and whether she loses potency by exposing so much of herself or whether that is balanced by the power she negates in not remaining hidden.

What I do know is that it's very important to me that people see me as I am and that there's a real relationship going back and forth. I know.. that I go out on 1 imbs... in exposing myself--I'm pretty transparent. . . . That's really the meat of the thing for me. I keep trying to make sure that I'm so obviously who I arn that people can't lay power on me to any great degree. And I'm not really sure whether that's making me a less effective therapist.

(ETlen)

Feminism as an Ultimate Asset. Five faminist therapists said, in response to the question, that they went or the assumption that any immediate loss of potency that may occur by their responding out of their feminist values would ultimately be compensated for in the quality of the cverall relationship. They stressed their belief in the importance of a therapist: not being a blank screen, and foel that their sharing and answering questions facilitates the establishment of the solid relationship necessary to "get tirough a lot of negative stuff that will come up later. . . . I think that the most important thing is to do what you feel confortabie with, to be really real, as you really are" (Beth). They are saying that to do some of these things is a necessary part of 
being congruent with their values and belief system, and emphasize the ultimate potency of being themselves. One woman expiained that thase decisions are never clear but that as a therepist, "you have to weigh everything. Maybe in a certain situation you would be diluting your potency, but that would be weighed against not responding--which is more destructive." If she loses material at ore point by answering too quickly, it will come out at some other time. She went on to share an experience which validated her belief in going anead with the femirist aspects of her therapy.

One of the argumients peop?e use against sharing themselvas is, "What if the person isn't ready--it can be destructive." My argument has always been, "We11, that may be so but I thinik there are nore cases where they are ready and it's destructive not to." Something happened [yesterday] which I felt very validiated about.... I have been seeing [this woman] for a little over a year, and I've been sharing myself with her all along. . . Yesterday. . . she said, "I ve come to see you as really an equal, and stopped putting you up." And it's true-she was always putting me up, and I did what I could to step down. She said, "I see a difference. You've always shared yourself with me, but I wasn 't ready to hea: it, so I just turned $i t$ off when you did. In the past few weeks, I've been listening and letting it sink in." I thought, "Far out! When she wasn' $\mathrm{c}$ ready, she didn't hear it and she turned off."

(Karen)

Three of the feminist therapists in this group criticized the Freudian model of therapy (see also Other Therapeutic 1ssues), arguing that no matter how potent or powerful the analytic method in which the therapist remains a blank wail, doing so places the therapist in roles they don't want to be in and carries with it assumptions about people they reject.

Not disclosing and not making yourself human is very powerful, and a lot of good material can come out of that and and lot of fucking people over can come out of that. If $I^{\prime} \mathrm{m}$ going. to er', I'm going to err in the direction of opening my mouth too much.

(Betsy) 
Therapy is Mare Important thar Feminism. Nine feminist therapists. the majority of those interviewed, said that whether they did certain "feminist" things in their therapy was always governed by the readiress of their clients and their assessment of the therapeutic situaticn at that point in time. This was more important to them than whether their behavior was particularly "feminist" at any moment.

It's not an either/or thing. . . . I think eventually if you don't make some connections to the poiitical structure, you're copping out . . But sometimes I'm asked a question and I really would like to deal with what they're asking me, what it is they want to know. Other times 1 have no quaims about answering them right away. . . We get back to the old thing about clinical intuition. . There's some peopie who are good therapists and scme people who are not, regardless of what they do.

(Marsina)

They explained that a number of considerations always go into their decisions about what they do at any point in therapy--tne timing, their own warits and needs, non-verba? cues, and, in the case of answering questions, what kind of question it is.

One woman distinguished between feminisii as therapy (explicated by Mander and Rush 1974) and therapy done by a feminist. Both are feminist therapy, but her maintenance of a priority focus on the dynamics of the therapy situation over the feminism puts her in the second category while those doing feminism as therapy focus on the feminism first (Nancy).

\section{Other Therapeutic. Issues}

Theoretical orientations. At various points in the interviews, corments would be made spontaneously about different theoretical orientations of therapy, in particular positively about. Gestalt, negatively about 
the Freudian psychoanalytic model, and both positively and negative?y about the Jungian model. 14

Five therapists discussed Gestalt, saying that they felt its theoretical orientation and method of practice lent themselves well to feminist therapy.

[Gesta]t] is not the traditiona] patient/therapist model. My orientation as a Gestalt therapist is alyays to be who I am, to say my feelings. If I'r angry, be angry: if somebody's doing transference onto me, to not let it develop... II work on] having a person get in touch with her cown strength and taking responsibility for herself. So those are all ways which lend themselves very well to feminism.

(Karen)

Several mentioned the congruency between feminist therapy and Gestalt's dual focus on individuals taking responsibility for their lives and on the therapist refusing to accept power.

I'm constant?y giving the individual responsibility for themselves. I'm only a vehicle. They can use me to get in charge of who they are as womer. . . I I see that my whoie job--and this is a lot what I got from my training in Gestalt--is to nake women take responsibiiity, so that they can say "yes" and "no," so that they learn how to ask for what they want, learn how to get in touch with themselves.

(Carol)

The neat thing about Gestalt is that [it helps me] back away when I feel I'm getting out of hand. There are lots of ways for me to back away and throw the power back on the other person, because of the Gestalt work I do. That what. . Gestalt. . . is all about--throwing the power back. People try to give it to you--you give it back to them.

(Ellen)

14Bioenergetics and Transactiona? Analys is vere also mentioned, but by only one or two therapists and generally positively with little indepth explanation. Therefore, they are not included here but encompassed, when relevant, into the discussion of the question during which they occurred. Likewise, "traditional therapy, "while referred to frequently (generally critically), is not equated here with the freudian model because what "traditional therapy" actualiy refers to in each instance is context-bound.

Analys is of the data from the questionnaires returned by the sample frame is congruent with interview responses. Of the feminist therapists in the sample frame, 72 percent indicated Gestalt as a theoretical orientation, while only i? percerit indicated a Freudian orientation and 12 percent a Jungian one. 
Those feminist therapists trained in Gestalt also mentioned some of their criticisms of it. It assumes that a therapist can be valuefree, an assumption many feminist therapists feel is not possible and/or not desirabie. At times altrough they see Gestalt as highiy effective for "heavy" work because it is so "clean," removing the therapist from the interaction, they feel that as a feminist therapist they want to provide more contact and irvoivement. Similariy, although a strength of Gestalt is its focus on individual resporisibility, that can also be one of its disadvantages in that by focusing so much on incividual responsibility, it ignores ways in which the society impacts on individuals. "Gastalt tends to be too much individual responsibility and not enough how society fucks you over" (Kareri). One therapist (referring to the work of Steiner 1974) wondered if perhaps using Gestalt was merely another way of heiping women do what they aiready have perinission to do--.to feel (or, in TA terms, to be in their child ego state)--and not helping them learn to think and problem-solve (or to be in their adult ego state).

Seven feminist therapists discussed psychoanalysis or the Freudian model specifically. Six of the seven were very critical in their remarks. They saw that model's focus on transference, therapeutic distance, incerpretation and resistance as increasing the power the therapist has over the client.

I was trained in the Freudian model . . and that has inherent in it a kind of attitude that if the patient doesn't want what you want, then the patierit is being resistant. [According to my mode1.] if the patient doesn't want what you want, then the patient probabily knows what he or she needs. And you need to try to accomodate their struggle, . . . to try and do what people.warit.

(Beth) 
While discussing whether being a feminist therapisi meant that they lost potency by not using some more traditional techniques, three therapists said that to practice anaiytic methods aiso meant that a therapist had to be assuming on some level that the client was sick or weak, an assumption which runs counter to their basic belief-system as feminist therapists.

To turn questions around and not self-disclose in generai I think is a cop-out. . . That,'s the whole objective bit, that the therapist is supposed to be a blank wall on which the person projects all their transference. I think that the whole psychoanalytic point of view assumes that the patient's pretty damn weak. . . It's a medical model, and it also puts the therapist in the role of rescuer--"Let me figure it all out and then I' 11 tell you what to do" or. "I know but I ain't going to tell you." and that's even worse. So then [the cijents] put a lot of energy' into psyching [the therapist] out, rather than putting energy into dealing with themselves, changing. I think the traditionai model is ineffective. It keeps people in therapy for years and years. (Holly)

In this context, severà mentioned trárisference. Some said that a positive aspect of Gestalt, in contrast to psychoanalysis, is that it did not encourage transference to develop. One therapist said that one thing she did with her feminism in therapy was not to label things a client said transference (as she felt an analytic therapist would) without carefully checking herself for any responsibility she may have in what occurred (Karen).

One therapist interviewed receives case consultation from a Freudian, and provided the one positive view of that orientation. She believes trat many of Freud's more anti-koman notions have been discarded by most Freudians, and that other aspects of that approach are useful for her to integrate with her feminism.

I know what Freud says about penis envy--we 311 do. What I think is that a good Freudian shrink, and even a mian, doesn't 
work urider some of those old conceptions. I think that's a good bone to pick, to focus in on formulating some of the new ways that we're looking at things, but in terms of what Freudian shrinks out there are really doing, I'm not so sure they're al] doing interpretations back to a woman about penis envy.

(Nancy)

Three therapists discussed the Jungian orientation, one very positively and two more critically. A woman influenced by Jung's work finds the concepts useful in her feminist therapy. She believes that people need to incorporate both the feminine and masculine sides of themseives, and identifies (particularly in Berkeley where she practices) the most pervasive problem among both the men and women she sees as "a valuing of the masculire side [intellectual abilities, aggressiveness, assertiveness] and a losing of the values of love and affection and nurturing and gentieness" (Beth). In her therapy, she works to enable her clients to actualize whichever of the two principles they may have lost, in part by giving permission to the people she sees to value and incorporate the devalued "feminine" side of themselves. She explains that when she talks of the "feminine principle," she is speaking historically rather than inherently. However, she finds that it is "unpopular" to have this orientation. So it is not surprising that the two therapists critical of this orientation said that a way they incorporate their feminism into their therapy is to refuse to deal in male-female poiarities, whether that would be haying a dialogue between the male and female parts of a person or using the Jungian framework of animos/animas.

I want her to feel that her aggression doesn't have anything to do with her maleness--it's jlist her. To make that separation bothers me inasmuch es it eliminates a wholeness. If the aggression's going to cone, it's going to come out of her feminity, because she's fenale. 
Finally, in discussing issues in incorporating feminism into therapy, one woman said she wished there was a psychoiogy of women. "I wish that there was more systematized knowledge on the psychology of women, as a special class. Most psychology is really the psychology of men. . . I feel myself sometines lacking in concepts" (Holiy).

Issues with Other Professionals. In response to the question about issues for them in combining feminism and therapy, four women discussed confronting the sexism of other professionals. One therapist explained that she is starting to get "touchy" about male therapists who "are doing some of the same old numbers," thinking, "By now they ought to know; they ought to have changed" (Pat). Another therapist explained that for her, the issue came up at staff meetings when she heard something she disagreed with as a femirist.

If I hear something I disagree with, do I stand up and say, "My position is different from that," and how. It's very scary for me to do that. It's very scary for me to make myself controversial. I have all kinds of fantasies of being able to do so and have a hard time carrying through with them. So [then] I feel I'm not being open abnut who I am. . . It doesn't come down to a matter of being dishonest. It comes down to a matter of how much I take the initiative of putting myself forward and how can I do that in ways that will work or that I can handle. . . And then I lay all kinds of trips on myself about am I really so weak and ineffective that I can't act on what I believe in anci do I have to be in a closed interview room with somebody giving mie status in order to be effective. (Joyce)

Recentiy, she has begun teliing people this is a struggle for her, and talking with the women at work she particularly trusts. For another therapist, a struggle has been to break through an early decision to "never trust women." This is much more of a problem for her on a peer or professional level than in her therapy groups, particulariy in terms 
of rinding herself not respecting the opinions of other women therapists and fearing they won't respect hers (Cheryi).

\section{HOW DOES FEMINIST THERAPY PERCEIVE AND INCORPORATE FEMINIST ISSUES}

During the interview, and particularly as probes to the question about what the issues were for them in combining feminism and therapy, feminist therapists were asked how they perceived and/or incorporated feminist issues related to therapy, in particular working with male clients, anti-professionalism, consciousness-raising as an alternative to therapy, therapy as merely an individual solution, working with women only in groups, the differentiation between cultural problems and individual problems, and the limitations of therapy. Their responses compose this section.

As explained in Chapter III, many of these issues were suggested by the review of the literature to be current ones debated among feminist therapists. However, interestingly, as mentioned in Section IV of this chapter, when asked to list issues for theil in combining feminism and therapy, these feminist therapists raised almost three times as many therapelitic issues as feminist issues. Those femirist issues having to do with therapy are included in this section, while those having to do with feminism itself are included in section II.

Working with Male Clients

Feminist therapists were asked if they worked with men or thought they could work with men. Of the 17 responding, all did therapy with 
men under some circuristances or thought they could. ${ }^{15}$ However, some qualified their answers and sone did rot, and those qualifications were to greater and lesser degrees. Eleven said they thought they could work with men, and did not qualify their answers. Five women sãid they worked with men, but emphasized the difficulties, and one did not work with men in her private practice where she had a choice but did see men in the community cinic where she worked.

Yes, Can Work with Male Ciients. Eleven therapists said without qualification that they thought they could work with men. Two women said that although they thought they could work with men, in actuality they saw only one man or none at all. Some gave examples of particular awarenesses they had about men, but did not indicate that this made their work any more difficult. For example, ore woman saw women as more able to express their feelings, develop rapport with each other, ard not needing "to go through 'macho' roles with each other." Therefore, she feels part of her feminist therapy with men is helping them express those things and pointing out their particular "stuck areas." However, she would still to essentially the same kind of therapy with both men and women (Diane). One said she makes political connections with both men and women. Another feels that although she sees some men who have trouble being asserive and "rationalize their difficulty with actualizing what has traditionally been a masculine role in terms of feminist... politics," the most pervasive probienis she sees among both the men and

15 Arialysis of the data from the questionraires indicates that 45 percent of the feminist therapists in the sample frame reported that women were a focus of their practice, while 18 percent reported a focus to be on men and women both, 18 percent on couples, and 11 percent on families. 
women she works th is, in a jungian sense, an over-vailuing of the masculine side (th). Two therapisis said they thought it was important for them to work with men, for their own benefits, so as not to be operating in a "iemale vacuurn" (Alice).

Work with Men, But there are Certain Probiems in it. Five women said that they did see men, but emphasized the problems they had or the qualifications under which they would work. with--or thought they could be effective with--men. Ore therapist said that the problems men brought to therapy were completely different. Sne found women to be much more self-conscious ard ill-at-ease with their bodies and felt that the issue of self-assertion for wonien was a much more cortinual, deep-seated problem. On the other hand, she finds that she feels much easier about making physical contact with women than she does with men, feeling with men more separated by her power as a therapist and feeling from the men "the sense of resistance to me as a woman sometimes" (Ellen). One woman finds herseif at times impatient with men.

I'm also sometimes impatient with men. Partly not wanting any more to be very sympathetic with men's problemis. It's kind of like, sometimes, "OK you guys. I went through it once before when you were being male chauvinists arid nobody knew it and I was sympathetic and I understood and I juoported you and held you up and all that. So now that you're changing your consciousness too, 1 don't want to go through the same trip. Go do it on your own." [I'm] not wanting to nurse anymore. (Pat)

This therapist also works in a setting in which the peopie she sees most frequentily are men who "are not feeling and rot being in touch by drugs and alcchol." She finds it one of the ironies of ner work that for this particular group of people, feminism runs counter to their therapeutic needs. 
The way to their hearts and mincs and their sculs is not through militant feminism by any means! And sometimes my being strong, my being tough, is a drawback. And yat it's the only way I know how to survive when people start yelling and screaning and throwing furniture around. So there's a bungle. They're expecting that as a woman I should be sweet and docile and be very nice to them ard I'mi not. At points i ike that, a feminist background I don't think is therapeutic, but it sure helps me survive.

(Pat)

For another therapist, her froblem in working with men is just the opposite. With the few men that she sees (who she considers already atypical because they are men who are involved with feminists), she finds herseif being more understanding of the man's probiems with expressing feelings than with the woman's. "I sort of feel sorry for [the men] or something. So I end up being real nice to them. ... [Then] they play all sorts of games to avoid feelings--I'm aware that's a problem" (Holly).

Two therapists in this group who work with men but noted the difficulties discussed the particular iimits they set with men.

One of the things 1 tell the men when I interview them [for the mixed group I do] is that they're going to have to struggle if they're going to be in the group. They're going to have to struggle with their sexism, with their chauvinism. And if they're not willing to struggle with that, then [they shouldn't] bother coming to the group.

(Karen)

She finds that there are very few men for whom dealing with their own sexism is on their primary agenda for therapy. However, al though she does not feel the same commitment to men in general as she does to women and knows it's an "unpopular position" to work with men, she finds her work with those few men who are willing to struggle with that particularly rewarding. The second therapist who vorks with men in a college setting described her experiences with a group of maie students which led her to conclude that she can work with men "to a degree." 
I became very invoived with a coupie of male students who were very interested in what feminism had to say. . We had lots of long talks about what it was all about, and there were lots of "ah-ha!" clicking trings. They were also willing to do a lot of reading. . . It took nore patience to deal with men on miy part. I could feei myseif getting very frustrated, a lot because or the male behavior in terms of dominating conversations. I found myself having to cuting some of the things I thought men were all about in terms of what society had done to them and . . . [say that although] probably they saw themselves as very open . . . people,... they were still erigaging in some behaviors that were counter-productive to at least my growth and I found that offensive. . . We talked a long hard time about that and ultimate?y I sent them to the Men's Resource Center at the Y... . I think they really had to deal with men to . . . get in touch, to really have their consciousness raised about themselves as men. But I still think that it was helpful for them to work [with me] on that, to talk to me about that, and to be able to develop a re?ationship.

(Sue)

Do Not Work with Men when an Option. Finally, one therapist said that in her private practice, she does not work with men. "I do not choose to do that. I don't have the energy to spend. It's that I do not want to put my energies there." However, she does see men at the community mental health clinic where she works, and there is a certain amount of conflict in that for her. Despite her desire not to put her energies into men, she feels that in her role as a family therapist, it would be uriethical for her not to work to the best of her abilities with the men in the families of the children she sees (Marsha).

Professionalism and Training

As discussed in Chapter II, Tennov (1973) argues that professionalism and feminist therapy are mutually exclusive. Her position was explained to the interviewees and they were asked to resuond, as follows:

One woman in Connecticut writes that if a woman is a profes.sional (meaning she has an M.S.W. or a Ph.D. or an M.D. or whatever), then she can't be a feminist or a feminist therapist 
because that professionalism carries with it so much power and authority. What wou?d your response be to her argument, and what is your thinking about the skiils, training and/or professionalism necessary to do feminist therapy?

Fourteen of the 15 feminist therapists interviewed disagreed with this position, some very strongly, arguing that having a professional degree could but did not necessarily mean one identified oneself as a professional or abused one's power as she indicated was inevitable. Whether or not a therapist had used her professional degree to wield power over clients or to obtain the necessary skills to do good therapy depended, they felt, on the therapist and not on the attainment of the degree. In answering the question about skills, the response was generaily that what the necessary training was to be a feminist therapist was fairiy unclear, but whatever that additional training, it had to be beseo on solid clinical skills.

Professionalism. As several therapists explained, the issue yas not professionalism but professional identification, whether or not a therapist had moved beyond the sheer fact of degree attainment to identify herself as a professional and therefore different from and superior to those witnout the degree---in other words, whether sne used the degree to maintain an elitist position. They argued that it was as likely that a feminist therapist would have "lousy skills" as it was that a "professional" therapist would abuse her power, or that a paraprofessional would be highly competent and a professional incompetent. "I know some pretty powerful women who don't have a degree, and I know some real wimps who have degrees" (Alice). Those two feminist therapists in the sample who did not have college degrees disagreed with the argument as much as those who had advanced degrees. 
Two therapists explained that they thought Tennov's position held less credence now than four or five years ago.

I think she's behind the times. . Because more and more, fewer and fewer people are seeing degrees as that blanket credit card to get into heaven and have alt people agreeing with you, as used to be the case. More and more peorle challenge authority..., and... believe [competency] is in the proof of the pudding. It isn't the degree that does it. . . I I think becoming a professional and getting a degree maybe has more mysticism for her than it does for me. For me, it was like getting a linion card. I did aI! my work, paid my morey, and I got a union card. Now the only way l'in going to be successful and have anybody see me as an authority is if I do well.

(A)ice)

One therapist said that she "responded with anger" to the presentation of the argument. She continued, explaining that the "anti-professionalism nonsense" in the movement in the late sixties and early seventies happened because male radicals decided "being a professional was a bac thing and so of course women shouldn't do it either, just atout the time women were getting up their courage to go be professicrals." She feels angry that holding to this position has meant that women who colitd be professionals have accepted this rationalization for not succeeding.

I'm really angry about ail the women who were bright and skilled and competent, who could be with me in the professional world, who decided to. . . cop out. I really see that as a "Dori't Succeed" on the part. of a lot of women. And' I'm angry that they haven't gotten their shit together so that they're up front doing whatever they're doing instead of "whooshing" around somewhere in the back. I think that's just using bad politics as a rationale for not succeeding. (Pät)

Another therapist said similarly that not only did she see no discrepancy between being a feminist aind beirg a professional, but that she felt that "strong women who believe in themselves and believe in other wonen . . have almost a responsibility" to become professionals and act is models for other women. The one therapist who did feel that 
Tennov's argument had credence said that she dealt with the conficics inherent in professionalism by accepting them, living with them, and attempting to minimize their potential impact in her therapy.

Training. The clear position among feminist therapists on how much training was necessary to do feminist therapy was: "as much training as it takes to do good therapy." The emphasis was that doing therapy--including feminist therapy--required therapeutic ski1ls.

I think [ to do feminist therapy] primarily you have to be a good clinician. If you're not good at what you do, it can realiy be a drag, to feminism, to the novement. . . . So I would say that the first thing that reaily matters is having a good soijd beckground and training... I do beileve that feminist therapists owe it to themselves and to everyone else to get the best possible education, the best possible training, that they can. (Alice)

For some, those skills came primarily from supervision, for others from college and university training, from experience, or from one's own personal therapy. Five seemed to feel that degree-oriented professional training was important, explaining that as the systen was currently set up it was one of the few ways for a womian to get good therapy skilis, while five others were more critical of the training that went on in colleges and universities or didn't feel such treining was necessary to be a good therapist. However, all returnad to an emphasis on the importance of skills and training of some form or anctrer. As one therepist said, "I find I'm much safer with ny skills than I would be without them" (Ellen). They explained that because they had skills, they knew how to keep the power differential minirized, and they knew how to handle the severe problenis wornen may bring to therapy. As discussed in Section IV (under Power Issues), some indicated that having therapeutic skills did mean they were different from their 
clients but not necessarily more powerful. "I've got some skills that other folks don't have, but part of the work 1 do is transfer those skills. I have no irvestment in hanging onto them. I want everyone to have the skitis I have" (Teri).

In discussing the particular training need for feminist therapy, one woman pointed out that aside from some skill-building in areas like assertive training, there was no training in feminist therapy yet. One therapist said that feminist therapists had to supplement gcod clinical training witn women's studies and that perhaps this would mean segregating themselves for a portion of their training. Otherwise, no one seemed to know what the training for feminist therapy should be aside from the training for therapy itself.

Consciousness-Raising as in Aliternative to Therapy

Following the implications of articles in the riterature pointing to the profound changes in women who have been in a consciousnessräising group and those advocating consciousness-raising as an alternative model of therapy for wornen, feminist therapists were asked if they agreed with the argument that many women don't need therapy at all if they had a good consciousness-raising group. They disagreed, explaining that the statement was too simpiistic and that while consciousnessraising could mee $i$ some needs of some women, it had the severe limitations of facilitating anger but not change, in addition to not being appropriate for the needs of very severely disturbed women.

Manny feminist, therapists began their comments by saying that the statement was true, for some womer. They emphasized some strengths of consciousness-raising: it can give women support, a chance to express 
themselves, practice self-assertion, and gain self-assurance and selfconfidence. For these things, some feel it is probabiy better than oneto-one therapy. However, they objected to the assumption that because consciousness-raising had strengths, it was the answer for all womeri. "To say 'All a woman needs. . .' is like saying, "All she needs is a good lay"" (Alice). They went on to discuss the limitations of consciousness-räising. One limitation mentioned by eight feminist therapists was that consciousness-raising tencied often to be a "dead end" (Holly). It evcked anger and then could not provide channels for change, thereby "boggirig down in a sense of outraged victimization" (Ellen), in complaining, playing "Ain't It Awful" games, advice-giving, mutual pitying, and "bullshitting" (Marsha).

I've seen too many womer in consciousness-raising groups where it got to a point where al1 they did was express their anger. It was a good place to express their anger against men, and it didn't go any farther than that... It was like the flip side of a coin--the anger then kept thom in the same [unliberated] position.

(Peg)

These therapists feel that therapy offers ways to work through the anger, to not stay "stuck" with it, to move beyond anger into action.

Hopefully, therapy ought to help a woman resolve the conflict and move on, to keep moving up in her own level of awareress and ability to deal with the world, and know how to be effective about what sine now has her consciousness raised atout--how she can get into action in an effective way and not just stay avare and infuriated. I think there's just no way you can help but be mad if you're awere. If your consciousness is raised and you haven't been angry, something's missing; but to stay embroiled in it rather than using your anger effectively, channeling it in a really effective projuctive way--that's where it's at. And I think that's where consciousness-raising sometimes... didn't carry through. It just wasn't equipped to carry through. That wasn't what it was designed for. (Aijce) 
Four other therapists also mentioned that woninn may need therapy to handle the implications of the consciousness-raising. One therapist explained that many women she worked with had been in conscicusnessraising groups before but at a certain point feit that there were things they needed to deal with in therapy, "like the part of a person that would collude with her oppresser, interralize thet, [or working on] not laying trips on other people or buying other peoples "trips" (Karen).

Five therapists said that there were some women who needed "more" than a consciousness-raising group could provide. "Some people need therapy," said one : yoman simply (Diane).

There are some women, just like some people, period, who do need help beyond [consciousness-raising], who do need to look more deeply into their own lives. Although their problems may be extremely confounded by the fact of their power?essness in this society and their lack of support in terms of who they are as women and their perceptions and value systems being very discrepant with what is labeled health in our society, I think their problems are much deeper than [consciousness-raising can deal with], and they do need some kind of therapy, some kind of one-to-one help. (Sue)

One therapist explained that while on the one hand, therapy was often over-mystified, to believe that consciousness-raising could help all people with all problems was to over-simplify therapy (Teri). While most therapists agreed that consciousness-raising had strengths despite some limitations, one woman cailed it a "total political flop" because "it took women away from struggling and got them into talking abolit it. . . . It got us away from action. . a and . . my ultimate goal is always action and radical change" (Marsina). Nonetheless, she and another therapist said here that they feel that a consciousness.raising group would still be far superior to traditional arralytic psychotherapy, but both also think that their models of therapy 
for women are superior to either".

I think that if a womar has to choose between a psychoanalyst and a consciousness-raising group, she should be a consciousressráising grcup. If â woman could have her 100 percent druthers about what would be the best thing, the best thing would be to be in a problem.solving group led by a feminist. (Teri)

If I can deliver something, hopefully they won't have to go to the corsciousness-raising group. They will have bypassed that. They will go and te with women and seek women out and have that support, that foundation. (Marshà)

Finally, one therapist explained that she felt that the idea that women didn't need therapy if they had consciousness-raising had to be understood in its historical context. At the time when the position was argued most strongly, there were few therapists who identified with the women's movement, and no feminist therapists as such. For a woman to enter a therapy group at the same time that her consciousness was just beginning to be raised "would have been disastrous because we were a!l scared we were going to be labeled crazy. Find I'm not sure that that was [a] totally unjustified [fear] in some cases" (Pat).

\section{Issue of Therapy as an Individual Solution}

One probe posed the following theoretical issue raised by the literature review:

Given the idea that it's the social system that produces many of the problems vomen bring inio therapy, do you ever ask yourseif if therapy is on?y an "individual solution," fixing one person at a time while the whole system's continua?ly producing more problems?

of the 16 feminist therapists responding, six said they did see therapy as an individual solution and went on to explain their viewpoints, seven said they thought both on individual and a societal focus were needed, 
and four said they did not see their therapy as merely an individual solution. 16

An Individual Solution. Those who saw therapy as an individual solution explained their dilemma. On the one hand they feel strongly that women (and people) will continue to be oppressed and therefore have emotional problems as long as the society continues to socialize women into second-class citizers. Thus they see the inpacts of their therapy as always uitimately limited and minimized by the society. "In a sick society, how healthy can you get?" (Karen). To a certain extent, acknowledging that dilemma at least destroys any attempts at pretense. They speak of their work as "bandaiding" and "patch-up work," and seem to feel that in their ackrowledgment of the rimits of their therapy comes a more realistic perspective in which therapy goals are set not toward individual change but toward social (aná, for one at least, revolutionary [Marshä]) change. Another therapist has come to accept the ircny that what she does best (smail-scale work) is least likely to provide the larger-scale solutions she thinks are ultimately necessary.

I think [the argument above] is a real problem, and I think that's true. I'm aware of that. I'd like to see largerscale solutions. I've come to pretty much accept that the way that I work best is on an individual or small-group level. I guess in some ways I value political action more and think that's more important, but that's not where I'm! at and so I accept that. (doyce)

Twc women said that one thing they did with the irony they faced was focus on groups, for cre on building support groups for women as a way

160 ne gave mixed answers and is counted twice. 
of "spreading the word" (Holly), and for the other any situation in which one person can impact on more than one other person, such as work in schools and with large groups (Ann).

Need for both Individual and Societal Focus

Seven therapists irterviewed said that they felt that therapy was not "just an individual solution" because changes in individuals impacted on the social environment, and vice versa. They believed that a dual focus--on individual charge and on societal change--is necessary. They explained that as women begin to change, feeling their own strength and power, the institutions around them will change, ultimately changing the society.

I feel that there is no way of railroading somebody who won ' $t$ be railroaded. As peopie begin to feel their own strength and say "no," that the institutions and the people around them are not going to be able to do the oid trip with them. I think that's even more effective than going in and trying to make some sort of mass movement that has a large contact but is not too sustaining.

(Chery?)

One woman said that in her opinion, a lot of people trying to change society are doing so angrily and therefore ineffectively.

As I see it, a lot of people go out in anger, angering the very people they're trying to make points with. That comes from their own personality, [the attempt to] get rid of their own anger they've stored up against mommy and daddy for so many years. [If you] get that out of it, then they can go out and be strong and deal with those [societal] issues. (Saiiy)

They feel that a good therapy experience can better prepare womeri to make changes in their lives, confront the sexism around then, and perhaps raise their children differently--"there's going to be some cumulative effect" (Alice). Dne therapist concluded that she doesn't see herself at all as getting people to adjust to the system. "It's not bandaiding-- 
it's people with power" (Elien). However, another therepist did say that at timies it seemed to her that the changes she was effecting on an individual level were being "snowballed out" by those aspects of the society which countered her efforts. Nonetheiess, she feels that as long as there are individuais who want what she offers, it's worthwile to provide it.

I have to agree. It does seein that the [societal] effect is really snowballing vay out of proportion, helping undo [my individual work, which seems] very slow and cumbersome and in terms of impact is jlist. . . nowhere near meeting [the need] .. It's iike the difierence between sending out handbillis and having a five-minute spot on coast-to-coast TV--you get a loi more done. And that's how I feel about some of the more negative cultura? things. I try not to be too pessimistic about it but I've got to admit. . I get depressed about that. But just because it's slow and it isn't having nationwide impact doesn't mean it shouldn't be done for the individuals who want it.

(Alice)

Not an Individua? Solution. Four therapists said that they did not consider their work an "individual solution." One said she feit her work was, instead, "a partial political solution" in that it enabled people to stop internalizing the messages from the society which got expressed as psychiatric disturbance (Teri). Another therapist explained that she disagreed with the argument preserited for two reasons. First, it assumes that the actual structure causes all emotional problems while she believes that there is no possible social structure "that could be created that wou'd ieave people conflict-free" and therefore that there will aiways be a need for therapy

There are these opposites--good and evil--in the world and in people. It's inborn. It's part of life. Life includes death. Whatever social structure occurs, you have to acknowledge that fact. . . I I don't think women have to be cporessed... , but ife is nard. People die. There are tragedies that there's no way that the world can be organized to avcid. (Beth) 
Second, she feels that however uniair it may be, it is possibie for some people, those who are the more privileged and not concerned with issues of day-to-day survival, to achieve self-actualization and create a fulfilling life in this society. Again, she disagrees with an underlying assumption of the argument presented, that all individual solutions are inadequate.

Two therapists don't see therapy as an individual solution because they've adopted a more laisse-faire attitude toward societal or revolutionary change. One therapist feels that "we have the power to be happy or sad, that we really make our own misery, . . . our own ?iberation or unliberation." She does not believe any woman is really subjugated, but rather that her priorities, be they security or the fear of growth or change, have led her to choose a subjugated role. From this view, therapy can help people deal with what's happened to them. Out of that; some people will want to go out and effect systemic change arid some won't (Diane). The second therapist explained that she doesn't feel that being in a therapy group takes away from people doing political activities the rest of the time--"Everybody has seven days a week." In addition, she believes that in this country, there is still a tine ahead of "figuring cut" in which she as a therapist can be helpful.

[We need to iearn] how to be brothers and sisters to one another, to grow together, to get rid of the things that we don't like and promote the things that we do. I think we stiil have a period of figuring out what ways work and what don' $t$; are there any scrts of therapy which are helpful, are there any which are not. I'm willing to help people explore. If self-awareness groups here help people feel better, decide what they wart in life, what kind of a scciety they want, then I thirk that I'm doing a good thing. . . Unhappy, lonely, scrunched up people don't miake good revolutions. Whether or not people want to make a revolution after they get happy and friendly and unscrunched, I cion't care.

( $P a \mathrm{t}$ ) 
She concludes that if people don't want what she has to offer, they won't come to her.

Working with Women in Groups versus Individually

Whether or not they felt it was important for womer to be seen in groups rather than individually for feminist reasons was the next issue raised in the interview. The position was based on the argument

sumarized in Chapter II that working with a woman individualiy removes the support and serse of unity with women provided in a group and does not encourage women to work and struggle together. Of the 16 feminist therapists responding, 14 felt groups were very important for women. However, five qualified their responses by saying that some women can't handle or con't need a group, and five said that their feelings about groups being better than individual therapy didn't have anything to do with ferninism.

Those 14 women who felt it was important for women to be seen in groups rather than individually said that a group both moderates the therapist's power and gives women support and exposure to a wider range of women's choices in ways that individial therapy can't do, or can't do as we11. A therapist who does groups for pre-and occasionally orgasmic women finds the groups to be a cruciai aspect of the therapy.

One of the major elements of the group... is that it's a group.. When they come together, one of the things that happens is that they no longer feel like a freak. . That support that the women give each other is probably the most important thing that goes on in the group. . . A woman in isolation will get so discouraged she' 11 just keep thinking that there's still something wrong with her. That's what the group [changes].

(Nancy) 
One therapist explains that a group is the place where women can learn to turn their nurturing abilities toward each other, as well as providing the therapist opportunities to structure experiences so women turn to each other instead of to her. She also pointed out that before she found a structure for herseif in TA and Gestalt, the women's groups she did facilitated victim positions. "We would sit around playing Ain't It Awfu?. . . To sit around and feel powerless and blame it on men and male structures was something that was going on a lot" (Holly). Another found, similarly, that in her women's groups, the women tended to pity each other, "so frequentry the only kind of feedback that is going on is this kind of pity which just curls the spire." When she is aware of this, she works to get at the jealousy between women she feeis is underneath (Ellen).

Five therapists said that they felt groups are very important for women but that there are some women for whom a group is not appropriate or who don't want group therapy. They point to women who will not or are not ready to work in a group, and women for whom relating to other women is not a problem and want (and utilize weil) their own individual therapy experiences.

Five women said they preferred to work with people in groups rather than individually not for any feminist reasons but because they believe therapy done in a group progresses more quickly and is more effective.

\section{Differentiating Cultural and Individual Problems}

One question began: "One thing the literature on feminist therapy stresses is the importance of not attributing cultural problems to 
individual women. Does that distinction make sense to yol?" of the 17 feminist therapists responding, nine said that the distinction did make sense to then, seven that the cultural and individual were too inter. related to be distinguishable one rrom the other, and one that she saw ail problems as political. The resi of the question and the probes. following were designed to alicit the theoretical responses of feminist therapists to this position and then examples of how they made the distinction beiween curtural and individual issues, if they did so, and what they did with cultural issues in the context of therapy. Further probes were designed to focus on what they did if a woman presented cultural problems as individual or personal problems and if she presented what they saw as a personal issue as cultural (in ocher words used cultural realities to absolve herself frommaking individual changes-the TA game of "Wooden Leg" or "If It Weren't For Being a Woman"). Sometimes, further explanation was given in posing the question, referring to the work of Chesler (1972):

Chesler says that one of the ways that tradicional psychotherapy "drives women crazy" is by taking cultural problems and labeling those the problems of individuai women that need to be dealt with in therapy. It seems that feminist therapists are not wanting to imply to any woman that cultural probiems are her problems. Eut it can go two ways. A person may be "blaming" the externais, the culture when in fact there is some real work she needs to do. On the other hand, there are times when a therapist can focus the work interrially or intrapsychically when they may be externals that need to be changed, when a consciousness of certain oppiessive realities needs to be fostered. Do those distinctions make serse to you?

Because of the complexity of the question and the length of responses, not all intervievees were asked all aspects of the question or all probes. In asking the rest of the questions and the probes, however, it became clear that often there were no clear answers, no one way 
feminist therapists deal with, for example, the cultural when it is presented as personal. The following discussion, therefore, will present the complexity of issues raised rather than any agreed-upon solutions.

Cultural and Individual Differentiation. Those who made a distinction between cultural and individual problems stressed the reality of cultural problems that exist for women.

I think women have to know when they're being assaurted by cultural pressures, that it's not some personal inadequacy of theirs that's causing them to be oppressed. (Beth)

The oppression is real. It's out there. The anger is important. Anger has a definite place in the world, and I don't think it should all be spent in therapy. I think it's a healthy reaction that women especially reel. (Holly)

However, the second woman goes on to say that "what's important is what they do with the anger." This is a theme that is repeated by others: given that cultural oppression exists and that it impacts on a woman's emotional wall-being, what is she doing with her awareness, to what degree is she contributing to her own oppression, and to what degree is she taking personal resporisibility for cultural oppression. They point to the "delicate integration" (Betsy) of cultural and individual problems and the complexity irvolved in understanding and in working with these issues in therapy.

There's been a fine line when I've wondered, how ann I going to approach this. Am I going to approach this in a "therapy way" or in a "consciousness-raising way"?. . Let's say there are two people who are at the same job and one is really fucked and the other isn't. Now is one more radical than the other and seeing more, or is one really having problems with authority figures. . And if someone doesn't struggie with authority figures, is that her problem or shouldn't you have trouble with authority figures cause aren't authority figures fucked? 
Often, the problem is further complicated in that women have incorporated aspects of that which is oppressing them into their own heads. One woman quoted this analogy: "It's really hard to fight a war when the eneriy's outposts are inside your own head." she continues to say that women need to "get in touch with the ways that they oppress themselves, that they cocperate with it and that they put themseives down" (Beth). Once women become aware of this, the degree to which they "coliude with their oppression" (Teri), then it is up to them to decide what to do in the future. The issue becomes pointing to persona? complicity without discounting the cultural realities and raising consciousness without embracing bluming.

If a woman's coming down on herseif, if she's taking personal responsibility for cultural oppression, that is very important to sort out so that she can get out of that self-blaming, selfdeprecating role. She reeds to know that there's a reason why she got married other than being overly dependert. . This is very complex. The difficulty with it is that if she's into selfblaming, she may easily get into blaming something else. A lot of things in the beginning consciousness leave a woman turned over from the point of blaming herself to just blaming society. (Nancy)

In this context, four of these women discussed the issue of rape. They see the traditional view as believing that worien who get raped have subconsciously "asked for it" or, in a Transactional Analysis framework, been people who are in victim positions. This view, they believe, discounts the reality of sex-role oppression. If a woman were raped, given the cultura? context in which they view it, they would focus not on her "victim script" but on her rage.

I think that rape is a social and cultural problem. I think that it's possible that women get raped who do not set themselves ap for it.... I think that some women were raped because they didr' $t$ have their eyes open and didn' $t$ take good care of themselves. But that's no reason for her not to be very very angry 
about the fact that some guy tricked her.. . So I think it's tricky. On the one hand, I would want to help a woman figure out how it might have been avoided. I'm aiways concerned with helping people take power in a situation where they were fucked over, so that it can get transferred to the next situation and won't happen again. But $I$ do not discount that men have no right to rape women, and that mien raping women is a function of cultural and social and political oppressión. I'm advocating for the woman's rage. Mobilizing a woman's rage is not necessarily reinforcing a game of Wooden Leg.

(Teri)

She goes on to explain more about how she often sees the label of "wooden Leg" as a discount of social and political realities.

If the game were [identified] in a iberal or conservative male-led TA group, a womar would say, "My husband is really fucking me over," and the therapist would say, "You're playing, 'If It Weren't for You, " which is a discount of the sex-role oppression which is going down and is not useful at that moment. (Teri)

These women were asked what framework they used to differentiate between "games" and realicy-based victimization, between righteous indignation and childish rebelliousness. One explained that what she looks for are the power issues in the incident. "Who's done what to whom. Who pays. Who benefits. Just iike we used to do [in the radical movement] when we analyzed corporations" (Pat). At a certain point, however, it comes down to each therapist deciding, based on her perspective and her feelings and her values, where she draws the lines. "Any time I'n perceiving something, I'm making a judgment" (Betsy).

As an exampie of sorting, several therapists explained issues they deal with around marriage. One therapist explained that generally, she believes that in relationships, "men take power, the culture gives them power; but wonen give it up." The question, however, is whether the therapist can aiways realistically expect a woman to take back that power she's given up, whether when a voman says she needs to leave a 
relationship to find her identity that's appropriate or not reaily necessary.

With some men, yean [she can take her power. back] 'cause there's enough flexibility in the relationship or the feelings are strong enough or something. With some relationships, after 15 years of doing it one way, he's not about to start letting her [take her power back]. To say to a woman in some of these situations, "You've got to take your power back," is not assessing the reality of that [situation].

(Betsy)

These five therapists who differentiated between cultural problems and personal problems were asked how they would know if a client were presenting the parsonal as cultural. Basically, they said that they dealt with such situations by incorporating both the cuitural and the personal and focusing on what the client was going to do abcut her situation. One therapist explained that she first focused on, "What's going on outside you that's making you feel bad?" Then, once that is "illuminated and demystified," she goes for, "How do you collude with it?" (Teri).

Cultural and Iridividual Intertwined. Seven feninist therapists said that for them, a distinction between the cultural and personal did not make sense because they saw cultural probiems and personal problems as so intertwined. In general, to a greater degree than those above who distinguished between cultural and personal problems, these therapists tended to focus on the individtal, and thereby on the individual's problems. Cultural probiems become manifested in individuals and thereby become problems for an individual to dea? with.

I don't think I. . make... that distinction [between cultural and personal]. They're so interrelated. What has been forced on me by the culture becomes a persona? problen. It can sometimes be very helpful, very freeing, to recognize the source of, say, my lack of self-confidence, that I wasn't supported to be very selY-confident; but insofar as i didn't develop that, 
it's my personal problen now because I didn't gain those skills all along the way.

(Sue)

Where does the dichotomy fall? An individual's prob?ems are the things that he's feeling. He's got social and cultural things piaced on him that would make it harder. There are cultural and society rules you accept, and some you don't accept. Ones that you accept that give you a problem are your problens, they become individual problems. (Ann)

From this perspective, they are less concerned with the sorting discussed above and more focused on things an individual can do. Since cultural problems are seen as just another aspect of an individual's problenis, problems with cultural overlays or input are dealt with in the same way in therapy as any other problem. One therapist trained in Gestalt therapy explains that "you get them to start . . Expressing it directiy and then say goodbye to it. . . . Then you can start defusing." A therapist trained in TA works to decontaminate the adult ego state. A therapist oriented more toward action said that the issue for her is not whether a problem is cuitural or persoriat, but whether the client wants to work on it and what they want to change. If they want to make changes, there are direct ways of doing so, such as assertive training (Sue).

While the actual therapy processes seem to be very similar between these therapists and those who distinguish between cultural and personal problems, the difference seems to be in the complexities or lack of complexities they perceive in the sorting process. Sorting becomes for the therapists in this group more a question of good therapeutic skills and of which issues are appropriate for therapy.

I think if you aren't out there in the situation and you don't have documentation and car't see. . . the institution's point of view, you car:'t know [what's reaily going on], so it makes serise 
to be personal. If th were a discrimination issue [for example], why is she coming to you instead of an attorney. (A. ice)

Another therarist explained that the way she would determine if what a client called a cultural problen vas one or not would te if she could locate some game that the client was playing on this and on other issues as well (Sariy). They do not deny that there may be cultural implications, but focus on the personal implications perhaps to a greater degree than those in the first cluster, with a goai of enabling a woman to "uncierstand how her own personal thing is making it impossible to deal with that situation" (Alice). One therapist gave an example from her own early experience of a time when someone presented to her what sounded like a cultural problem and she mistakenly did not look to the more intrâpsychic, personal aspects of what he was saying.

The first man I ever worked with . . . was having problems with what was going or in the world, the awful hurting that was going on, and feit a graat need to rectify what was going on. I started working towards what he could do and missed the boat completely because it had a lot to do with feelings he had himself of guilt as a child. . . So I think I see things more in terms of a person. I haven't lately seen anything that's realiy cultural, aithough I do talk about it. (Saliy)

All Problems as Political. Finally, one therapist does not make any distinction between cultural problems and individual problems because she sees all problems as basically poitical. "I don't see any distinction between the personal and the political. I don't see that difference. . . I'm not saying it's just the oppression of women that leads to all forms of mental illness bit I'm coming close to saying that:" (Marsha). At the same time, she explains that although this is her basic perspective, she would not imediately explain the political development of suicidal feelings to a woman who is severely hurting in that way. Rather, she 
makes therapeutic interventions, is sensitive to timing and to the nature of her client's distress, and waits until it is appropriate to introduce her perspective. However, it seems that for her sorting is also less of a concern because her basic assumption is already that a woman's emotional problems are basically political in nature. In response to an example given of a woman complaining of discrimination at her job when it seemed her own unresolved conflicts were at least playing some role, she said, "You can say to her, 'Yeah. Discrimination does take place.' To me, that's a reality. What do you say, that it doesn't?" However, she explains that for her the real issue is heiping women get in touch with their connections to other women, in part by getting them in touch with their rage.

If you can heip that woiran, first of all to validate that those are very real experiences for her and to get in touch with her rage involved in being a woman, [then] you don't have to worry about the boss.. Y You have to worry about getting people connected to their roots. What it's like being a woman. . . Then she will have as an individual. . . to make some choices. . Of what to do with her life. You cannot make them for her. . . I I really firmly believe that I am the revolution in some ways, and . . I hope they join me. If they don't, that's their choice. But then don't come to me afterwards and tell me you're depressed.

(Marsha)

\section{Limitations of Therapy}

Femirist therapists were asked if they ever asked themselves, "Does therapy work? What's the point of therapy? What are the limitations of therapy?" The objective of the probe was to elicit perspectives suggested by the literature review on therapy in relation to the larger sociaty, in particular isslies about therapy being an individual soiution (asked specifically in ancther probe), encouraging adjustment to the status quo, or being irrelevant when survival was an issue. Interestingly, 
few responses incorporated any of these ideas. Most feminist therapists spoke specifically about therapy itself, and its objectives, limitations and successfulness in the context of their own work rather than incorporating any larger perspective. Generally, feminist therapists felt that therapy did work. Three had some questions, and three were more critical. Of these last three, one discussed the "point of therapy" by incorporating a political analysis.

of the 16 therapists responding, ten said they felt therapy did work. Many began by saying they asked themselves that question often, especially when they were discouraged, but stili believed in what they were doing. They seemed to feel that there were particular things that therapy could offer, and those things they felt it did well, ariong them enabling clients to gain a sense of their own power and seif-esteein so they can set and achieve their own objectives, freed of societal contitioning. One therapist explained that she basicaily believes that what she does works but is also willing to accept that sometning else would work as well (Joyce). Another therapist distinguished between therapy as she did it, wrich she feels confident: works, and others' therapy which in some cases she thought was useless (Teri). Cne discussed the possible irrelevance of feminism when survival is an issue, but did not discuss the limitations of therapy (Alice).

Three therapists raised some questions about therapy. One said she asks herself if therapy really works, believing that it did from her own experiences and yet seeing many iriends make just as many changes without therapy. "Sometines I feei there is a certain sham in it being a profession" (Cheryl). 
Three feninist therapists were more critical of therapy. One said that for herself, she would go to a spiritualist bafore she'd go to a therapist, feeling that therapists tend to focus on staying within rigid techniques and often use therapy for their own ends. She says she doesn't see therapy "as a giving, . . . as a loving [relationship]-it's a doing something to somebody" (Diane). Two women questioned the ultimate goals of therapy, one by referring to the literature on the inerfectiveness of therapy and the political ends for which therapy has always been utilized. "Psychotherapy . . has always been politica? . . , it has been used to maintain a very coercive systen" (Marsha). This therapist does not feel $i t$ is possible for any woman to be healthy in this society, via therapy or any other means. She is moving toward a perspective in which she sees the oppression of women as leadirig to their mental illresses, and therefore always views psychotherapy as "patch-up work" at best, remedial work which will hopefully enable a woman to function well enough to join with other women to effect the basic changes that are necessary. Therefore, she questions whether feminists should even be in therapy.

I don't krow, if a feminist comes to therapy, if I wouldn't try to reinforce something else. . I don't know if I want to reinforce the idea of her coming to therapy as a feminist. In other words, does a feminist need psychotrerapy, . . especially the . . one-to-cne thing. There may be other things [that would be much better], mayte group support, maybe getting involved with women in other capacities.

(Marsha) 
CHAPTER $V$

\section{SUMMARY AND CONCLUSIONS}

\section{SUMMARY OF RESEARCH FINDINGS}

Who Are the Ferinist Therapists?

Analysis of the questionnaire data did not produce the expected differences among the three areas studied. The range of responses in the Bay Area was greater, but no more non-traditional than Portland or Seattle (a cursory overview of the interview data finds this conclusion supported). However, what does seem evident about these feminist therapists is that the diversity of the group in many descriptive aspects becomes, if viewed as evidence of non-traditionality and noninstitutionalization, a common theme among them. As generalized from the questionnaire analysis, a "typical" feminist therapist is a woman living in the Bay Area, most likely an M.S.W. in practice five years, working full time if not in private practice then for a public agency such as a community nental health clinic, where she sees clierits, particulariy women, individually and in groups, specializing in some aspect of women's problems, and basing her work either on an eciectic or Gestalt theoretical orientation. However, any such summary of characterizing infomation does not adequately portray the degree to which feminist therapists differ one from another in the specific detaits of their lives and yet to which the diversity consistentiy takes avantgarde rather than traditional, non-institutionalized rather than 
institutionalized forms.

For example, when asked to describe their theoretical orientations, 33 different ones were isted, of which 24 (73 percent) could be considered newly developing and non-traditional. Simitarly, feminist therapists are more often in private practice than working for an agency, whether public or private. $\dot{A}$ significart number have not utilized formal academic training in traditional fields (i.e., psychology, social work) to learn therapy. Areas of specialization are as likely to be rape, women in the middle years, feminist body work, or alternative lifestyle and adjustment as depression, phobias, and low self-esteem.

From the personal historias of feminism and portraits of feminist therapists, however, the common elements of their developing identification with feminism are striking, particularly because this identification is not something taught in any schoor or advanced by any one leader. Rather, these women came to feminism because its message had relevance for them, because it removed their feelings of isolation, providing them with a sense of support and commonality with other women, and perhaps most importantly, because incorporating feminism had a profound impact not oniy on their consciousness but on their lives. Becoming a feminist has meant for many significant and sometimes radical changes in self-concept, in life-style and in relationships with other. women. Most of these feminist therapists trace their identification with feminism to the late sixties and early seventies, and in this sense, they came to feminism as a group; but for each one, the identification was an individual process. Similarly, it seems that they became feminist therapists in mucn the same way, not because they were taught 
to do feminist therapy or modeled after a Perls or a Freud (i.e., a male model) but because they as incividuals found their own way to incorporate feminism and therapy. Either as feminists iearning to do therapy or as therapists identifying with feminism, their femirism impacted on their therapy and their therapy on their feminism, and a meshing occurred so that the two became no longer discrete parts of their lives but integrated as their feminist therapy.

How do Feminist Therapists Define Feminism?

From the responses ir this section, it seems that there is basic agreement among these feminist therapists on certain values and ways of perceiving as encompassing the feminist belief system (described in the literature review as the Feninist (riticue), the two major components of which are the belief that women differ from mer because of social conditioning on the basis of sex-role stereotypes, and that that socialization ho.s been destructive and oppressive for women, further institutionalizing them into certain restrictive and conflictual roles, benaviors, and careers which perpetuate their secondary status and produce emotional distress. However, as these feminist therapists define feminism, it goes beyond the socio-political analysis of the Femirist critique to encompass Feminist Humanism, a highly positive belief in the uitimate capacity of each woman for self-actualization based not on sex-role stereotypes but on her own self-knowledge and human potential.

In defining feminism, those definitions invorving beliefs outnumber those invoiving processes three to two, and those processes listed were, in general, less concrete behaviors than different forms of implementation of the beliefs they parallel, with the definition 
beginning with the word "enabling," "developing," "helping," "struggling," and "changing." "Confronting," "advocating," and "getting together" are slightly more concrete words but even here it seems that what ferinism believes is much clearer (and perhaps more important) than what it does.

When asked to specify basic (or minimum) criteria for being a feminisi therapist, certain divisions within this population of feminist therapisis can be observed. There is a distinction between those whose criteria for being a feminist therapist are basically that the person be norl-sexist, self-actualized, humanistic, and open to all pecple and life styles, and those whose criteria demand a deep-seated commitment to feminism, coming often out of that profound impact (both in raised consciousness and subsequent life-style changes) that the movement has had on a woman. The criteria listed by those in the former group, un?ike those in the latter group, do not seern based upon the particular oppression of women but rather focus on the development of all human potential. Similarly, the former criteria do not encompass high demands for basic life-style change, risk, sacrifice, or basic and significant changes in feelings and attitudes as do the latter. Within the former group there is concern that just being a feminist is not sufficient for being a feminist therapist, and in fact, because of what is seen as the anger, judgmental certainty, and directiveness of some feminists, may even be detrimental. Within the latter group, the belief is that being a therapist and being a woman, and even being non-sexist and humaristic, does not make a person a feminist therapist. 


\section{What is Feminist Therapy?}

If a theoretical orientation of therapy is defined in the traditional sense as encompassing a series of propositions, a model for problem assessment, a series of techniques, and a training methodology, then from the responses to the questions in this category, the one thing that can be said of feminist therapy is that it does not exist. Hovever, there are therapists who have incorporated feminism inco their therapy and who call themselves feminist therapists. This analysis will suggest that feminist therapy must be understood more as a social movement than a psychology, and less a theoretical orientation in the traditiona? sense than a belief system and a series of ways that belief system is put into practice. As a helief system, it is aģain striking that with none of the accoutrenents of most therapies--no feminist therapy journal, no (or very few) training seminars, no leader or mentor-and that despite numerous internal differences, the commonalities among feminist therapists in three metropolitan areas, each in a different state, are so sirong. As feminist therapists describe their reminist therapy, it is based on a belief system composed of the two compiementary parts of the fominist value-system--Feminist Humanism and Feminist Consciousness--of particular changes in the therapy relationship and in the role of the therapist which enable the therapy process to becoire congruent with the value-system, and of two processes--raising consciousness and emphasizing the commonality of all women--which enable the value-system to be not merely utilized by the therapist but in turn transferred to the client. In explaining the beliefs and processes of feminist therapy, it is important to note that as described above, 
definitions of feminism focus on beliefs rather than processes and therefore as a therapy needing processes, feminist therapy has had, in many ways, to cievelop for itself processes that will be congruent with its belief system.

This may explain both the lack of specific techniques of feminist therapy and the high degree of interrelatedness between the values of feminist therapists and the ways in which they incorporate them. For example, feninist therapists indicate that one thing they do is ask certain kinds of questions about roles and role behavior designed to break down sexual stereotypes, and that they encourage the women they see to similarly question these assumptions. In this sense, questioning and fostering questioning can be seen as a technique; however, it is also a value in that feminists value women looking critically at heretofore unquestioned roles and stereotypes. Similarly, in speaking of one's values or biases, the feminist therapists frequentiy mentioned the value they attach to being "up front" about their views. However, the process of doing this, of sharing and clarifying their values, becomes in turn a means by which they model this behavior and bring into question the values or assumptions their clienis may hold. This difficulty in distinguishing vâlues from process says a great deal about feminist therapy, for it reflects the congruence found--and emphasized--in this form of therapy between the therapist's values and the process of therapy.

Feminist therapy utilizes its value system in what may be a unique way: as a conscious, acknowledged filter. As the client speaks, feminist therarists explain that they have an added perspective--their feminism--through which what they hear is filtered. If the analogy 
holds, this may in part explain how it is so difficult for them to describe what they do, for what they are attempting to describe (i.e., what the cilent says and what they do) is a iready influenced by and filtered through their feminism. Feminist therapists are saying that What they hear has already filtered through and been heightened by their Feminist Mumanism and their Feminist Consciousness. It has âready given them a different or added perspective on a woman's potential for self-actualization, on her roles, on the nature and causation of her problems, and on the social structure. After something passes through the feminist filter, they then rely on their theoretical orientation. whatever it may be, to choose an appropriate response or technique, but the point is that their feminism has aiready impacted on that choice and ultimately that techniques are less important than that whole shift in values engendered by their feminism.

In addition, the feminist belief systen carries with a concern that the relationship between therapist and client be as equal as possible, and feminist therapists view changes in their role from that of the therapist in traditional therapy as necessary to bring this about. They see themseives as more concorned with power issues, more willing to self-discluse and more "up front" with their values than traditional therapists. They also feei that it is necessary for the traditional

TSince these changes were ijsted by 16 of the 19 feminist therapists interviewed as wat they did with their feminism in therapy and as what someone got from them that they wouldn't from someone who wasn't a feminist therapist, it is suggested that the fact that they were mentioned only occesionally in the response to the particular question asking for a cefinition of feminist therapy has more to do with that being the last ouestion asked in which the objective seemed to be to give the briefest possible response than with any inherent conflict in the results. 
Whent role to change from one of introspection to one of action, from wo of deperdency on the therapist to one of support from other women. These changes in the therapeutic relationship to inștitutionalize mituality must be understood in the context of the feminist valuesystem. If changes in awarenesses are the cognitive manifestations of ferinism, changes in the therapeutic relationship are the process manifestations. Without these changes, feminist therapy would be incongruent in process and cognition.

Finally, in addition to utilizing their feminism as a filter and thereby perceiving differently what happens in therapy and changing the therapeutic relationship to be egalitarian, half of the ferninist therapists mentioned raising consciousness and emphasizing the conmonGities of all women as two intertwined activities they do with clients. in some ways, this can be seen as the therapist returning to the client again through the fitter of feminism, for in essence these activities are designed to change the client's perceptions (to raise her consciousness) which in turn impacts upon her processes (how she relates to and identifies with other women) through feminism.

Responses of feminist therapists to the two dichotomous quotations iurthers the analogy. Ten feminist therapists (of 19) criticized the first quotation for omitting the feminist filter, while 12 did not feel that making political connertions (which omits process changes and iccuses only on changes in cognition) was the critical aspect of feminist therapy. As the definitions of feminist therapy show, client selfaccualization is seen to be as critical a part of feminist therapy as sucial awareness and social action. 
However, even though such analogies are supported by the data analys is and are helpfu? in understanding how feminist therapists utilize their reminism, it is also important to focus as weil on the diversity of responses and clear difference of opinion among feminist therapists. These differences fall along a humanistic/radical continuum. Those in (or moving toward) humanism are unsure to what degree feminism has changed their therapy and if a feminist therapist needs to identify herself as such or be a woman, agree that feminist therapy is heiping a client meet his or her goals and cievelop his or her potentials, and give egalitarian definitions of feminist therapy. On the other hand, those in (or moving toward) a more radical position stress the integration of feminism into their therapy and the need for feminist therapists to be womer who have a strong identification with and commitment to feminism, emphasize the impact of social and/or political influences ori a woman's goals, potentials, and ultimate self-actualization, and give sexualiy differentiated definitions. ${ }^{2}$

How Does Feminist Therapy Perceive and Incorporate Theraneutic Issues?

There is no one way feminist therapy perceives and incorporates therapeutic issues, but a common focus is the needs of the client. For example, when discussing whether incorporating any processes important as a feminist (such as reducing the power differential, self-disclosing, and so on: reduced their potency, most feminist therapists responded by

2Each fitminist therapist did not consistently respond from the same position on the proposed continuum on all questions. Thus, a therapist who gerierally emphasized the cultural aspects impinging on a wornan might also say that a man could be a feminist therapist. These descriptions, therefore, represent composite positions. 
saying that whether or not they did these things depended on their client's needs. In other words, while they constantly utilize feminism as a filter for flow from the client to them, they do not necessarily utilize it for flow from them to the client. They take a similar position on issues such as whether a heterosexual therapist can work with a lesbian client and whether they answer client questions, again saying that it depends on the client and the situation. They generalty take a position against diagnosis, but are willing to use it if necessary. Thus, in terms of therapeutic issues, feminist therapy takes a relative rather than an absolute position.

In their answers to questions about values and directiveness, power and self-disclosure, arother theme among feminist therapists appears--they are concerred about the nature of the therapeutic relationship. They do not want a power-structured relationship in which the therapist is "one-up" and the client is "one-down." Some would argue that this is because women have so often been "one-down" or in an inferior, secondary position in the society that it would be totaliy contradictory to then perpetuate that hierarchy in feminist therapy. However, it seems that this nay be less the rationa?e than a more basic value-position which highly emphasizes the positiveness of involvement, mutuality, self-determination, and openness. Whereas the feminist critique presented the cognitive aspect of the belief system, these values can be seen as the complementary process aspects. These processes thus become the means to counter or minimize the power imbalance they see as inherent in therapeutic relationships and thereby the influence of their cognitive beijefs and values on their clients. Accordingly, 
most feminist therapists are "up front" with their values not because they want to irfluence their clients with those values but because of the openness and minimization of influence that acknowiedgnent of one's values brings.

In the area of structure, encouraging client "shopping" for a therapist and having a comitment to fee negotiation, while not always ackrowledged as feminist things that they do, also have to do with changing the relationship between them and their clients. For example, if a ciient chooses a therapist, if therapy becomes a service she selects and purchases, then that will have inpacts on the therapeutic relationship and the therapeutic processes.

It is in the area of how directive to be, how much to raise consciousness and how much to respect the client's SElf-determination that some therapists seem to experience the greatest conflict as feminist therapists and that there are the greatest differences within the group as a whole. The diversity of position along a humanistic/radical continuun is again evident. Those who ore more humanistic stress selfdetermination, even though that may mean a ciient chooses to behave in "traditional" or non-feminist ways. On the other hand, those who are more radical acknowledge their desire for their clients to become feminists (or, for those who are somewnat less radical, to become aware of feminism) and see a focus on solf-actualization as complicated by the issue of to what degree a person can in fact self-determine $i_{1}$ an environment in which goals and potentiais are influenced by social conditionirg and social reaities. 
Their responses to the quescion of whether therapy is political or apoitical is hipiul in unifying this onalysis. Feninist therapists explain that all therapy is political; but they define "politicai" in a different sense than electoral politics or even feminist or movementoriented activism. They focus on the political as having to do with all aspects of jower, from the very personal to the largest social levei. Thus, what happens on a personal level, in terms of the client's power as a woman and the therapist's power in the therapeutic reiationship, becomes critical, for those are the politicã statements that they make and it is in its political statements, in the changes it is making in women's personal power and in relationships between women, that an important difference between feminist therapy and other therapies seems to lie.

How do Feminist Therapists Perceive ard Incorporate Feminist Issues?

From an analysis of responses to the question about issues for them in combining feminism and therapy, it saems that for feminist therapists, therapeutic issues (how to be a therapist and incorporate feminism--i.e., how directive to be, etc.) are more important for them than feminist issues (how to be a feminist and incorporate therapy--i.e., whether therapy ignores social reaitites, etc.). These feminist therapists gererally disagrae with thase issues from the literature review on which some fominists take very strong positions. Thus, many do feel they can work with men, that being professional is rot in contradiction with being a feminist, that therapy is different from consciousnessraising (and that consciousnessuraising in fact has certain limitations), 
that sroups, while desirable, are not always the ariswer for all women, that therapy does work and is usefu?, and that feminism by itself is not necessarily therapy. In responding to the questions about whether therapy is an individual solution and whether they differentiated between cuitural and indiviciual probiems and how they worked with each, as many feminist therapists stressed the integration of the individual and the societal, the individual and the cultural, as differentiated between them. Among those who did differenriate, some acknowledged these to be issues for them; but it is important to note that they arose only when presented as interview questions and not spontaneously as did, for example, the issues of directiveriess.

Perhaps what this illustrates is that feminist issues in therapy as presented in the literature and issues for feminist therapists are not the same. This may in part reflect the bias of the literature towârc that militancy or toward a judgmental certainty and directiveness which some feminist therapists criticized when discussing femirism. In any case, as responses to both therapeutic and feminist issues indicate, there is nothing innerently radical about feminist therapy. Some therapists are in fact radical in their feminism and in their politics, but there is, if not a split, a continuum of responses along a humanistic/radical continuum.

\section{CONCLUSION}

Within the feminist movement, as Chapter II described, there exists the divisions of liberal feminism, culturai feminism, and socialist feminism. As it was described in this study, feminist 
therapy has little to do with liberal feminism. Its goal is not reform through legal and political change but changes in individuals and institutions counied with the development of alternative institutions through the incorporation of feminism to produce basic cuiturai changes. In this light, it is important to see feminist therapy as one of many such incorporations, in conjunction with Women's Studies, women's hea!th clinics, vomen's art and media, among many others. Feminist therapy is not an anomaly but a manifestation of deep-seated changes in consciousness and process. Similariy, while three feminist therapists spoke of their anti-capitalism or socialism as well as their feminism, for the most part these feminist therapists seem to view political feminism as less important than cultural feminism. The insistence of cultural feminism on the inter-connectedness of the personal and the political, on the importance of consciousness-raising, on the development of egalitarian non-hierarchical and philosophically congruent internal structures of social relationsings, on an understanding of the particular oppression of women, and on the value of women and their relationships to one another, all fird expression in feminist therapy.

As cultural feminists, Mand?er ard Rush (1974:13-14) suggest that the key word in the new feminism is integration.

It might be said that feminism is an integration of various heretofore incompatible elements built on a collective base of thought-action-feeling. Feminism integrated the subjective and objective, the rational and intuitive, the mystical and scientific, the abstract and concrete aspects of the universe and considers them harmonious parts of a whole rather than ir opposition to one another. . . . We see a universe where everything... is integrated and inter-dependent, not: separated and conflicted.

The summary of the research findings suggests that integration and congruency are critical aspects of feminist therapy. There is a goal of 
integration of beliefs and processes, of the personal and the political, of internal therapeutic structures and larger feminist values, of feminism and therapy; and the criteria for integration is consistently based on an attempt to minimize contradictions and achieve internal congruency. Thus, feninist therapists stress action as we?i as introspection, focus on congruency between their client's needs and what they do, explain that the political has to do with personal power, and reject definitions of feminist therapy which do not includa changes in processes as well as changes in consciousness, for both the cilent and within the therapy relationship itseif. It is not that anyone explained to feminist therapists that they needed to be concerned about their power as therapists, about client shopping, about directiveness, to be feminist therapists. Beginning fron their basic movement toward cungruency by integrating two important parts of their lives--their feminism and their therapy (or perhaps, earlier, with their lives and their feminism)--and despite often very apparent individual differences in politics, they nave coritinually incorporated beliefs and processes, and chosen processes which are congruent with their beliefs.

As each feminist therapist described her feminist therapy, this integration ard congruency existed, and as all the descriptions are synthesized and sumarized, again what is apparerit is that same integration of beliefs and processes, with congruency between them. Thus, as utilized by the therapist, Feninist Conscicusness ard feminist Humanism are the cognitive aspects of feminist therapy, used as filters, and changes in the therapy relationship to institutionalize nutuality are the process aspects, integrating the feminist vaiuf-system and the 
therapy process, while what is then transferred to the client, consciousness-raising and changes in a woman's relationships with other women, reflects a similar integration ir what the feminist therepist returns to the client of her feminism.

Integration is in fact the making of multiple connections, and perhaps femirism and feminist therapy can be seen as the making of connections, not jlist between the personal and the poitical, but on all leveis---connecting feminism and therapy, connecting women to each other, connecting one's personal problems to one's social awareness, connecting one's beliefs to what one does, connecting what one does in therapy to how one lives one's life. Thus, unlike most therapy, feminism is not merely a means to alleviate stress used from time to time but a way of life for the therapist and potentiaily for the client as weil. "Therapy" becomes normalized, connected to rather than divideo from everyday life. However, there is one area in which the makirig of connections seems racking, and that is in the realm of the feminist therapist's poifitical positions, not so much individually but as a group. As early as 1971 , Freeman noted a division within the feminist movement between those adhering to an egalitarian ethic and those adhering to a libertarian ethic. In essence, this division exists within ferninist therapists as well; and while each feminist therapist has made her own integration of ferninism and therapy congruent with her own political position, this is an area in which the group of feminist therapists as a whole lacks integration. Thus, on importarit conclusion of the research is the awareress that feminisin is not in and of itseif inherentiy radical. Feminist therapists can be radical politically, and some are. Others may have a 
radica? view of the therapy relationship but not of society, and still others are concerned that increasing radicalness runs counter to their Feminism Humanism. From the discussion of the issue of values and directiveness, it seems this is an area where there is the most personal concern and yet group disagreement. Hopefally, out of this a neederd integration with cone.

At the same time, it is important that this focus on political difference and disagreement not iose sight of the differences between feminist therapists and other therapists. This is an area in which future and more rigorous research would be helpful--for example, comparing feminist therapists to other therapists, to other women therapists both sympathetic and antagonistic to feminism, and to other "non-sexist" therapists both male and female. The research of Pendergrass (1974) and Sundland and Baker (1962) suggest internal comparisons which could be made, or bases for comparison between feminist therapists and therapists who do not identify themselves as feminists. However, perhaps the most revealing direction for future research would be actual comparisons of the practice of these different groups or of their responses to audio- and/or video-taped stimulus presentations. Without this information, to pose a continuum of feminist therapists in which the end-points are numanism and radicalism beifes the existence of a much more important continum among therapists in which the far end is not humarism but sexism, a dotible siendard of mental health, and a high?y traditional model of therapy. Furthermore, for the feminist therapists interviewed, the time during which they have been making the comedions has been relatively short-for the most, ive or six years or iess. 
In the beginning, it seems feminist therapy developed as an antitnesis to what feminist therapists found hurtfur, oppressive and destructive in the male-fominated institution of traditional therapy. It began out of an attempt to be different from something rather than to be something. However, as more therapists and feminists are looking to connect feminism and therapy and to remove both sexism and traditional abuses of power from their therapy, meeting with each other in peer consultation, publishing books and articles, deveroping training and systems of referral, it is becoming clearer what feminist therapy. is, what are those basic areas of consistency and inner congrijty that exist among feminist therapists, what makes it different from other therapies, and in what areas feminist therapists differ from each other. Furthemore, as more therapists label themselves as feminist therapists and as more feminists learn therapy skills, feminist therapy will increasingly begin to impact upon the institution of therapy and on the lives of women. As feminist therapists continue to make connections, to struggle for congruency, and to develop new ways of further integrating feminism arid therapy, feminist therapy will itself become increasingly integrated and congrient. The process of doing this thes is has enabled those integrations and cornections to begin for me in ways that: are congruent with me and with my feminism. It is my hope, in turn, that the descriptions it provides of feminist therapy as it now exists and is practiced on the West coast will be helpfur in furthering that same integration for others. 


\section{BMLTOGHE:}

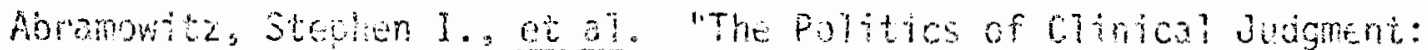
What Won!hera Examiners inier abut wonen who no wot stifle

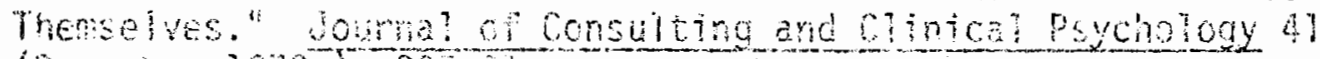
becmper 1972al: 3809 .

Abramowitz, Stephen I, arid Abrarowitz, Christine V. "Should Prospective Wher citents sek out Women practitioners? Intinations of a "Qingbat' Erfect in Cinica i Evaluation. "Procedings of the Blst Anuel convention of the American psychological Assoctation $3(1973 b): 505-506$.

Acker, Joan. "women and Social Stratification: A Case of Intellectual Sexism." In Changing Uoman in a changing society, pp. 174-183. rdited by wan hiber. Chicago: dinerstry of chicaso Press, 1973.

Acker: bon, etal. "A Fentism Scale: Repart on its Construction." Unquitishes paper, university of oregon. 1074 .

Adus, Nargaret. "Tho Compassion Trap." In Woman in Sexist Society, pp. $555.5 \%$. Edited by Vivian Gornick and Barbarr K. Moran. Hew York: New fnerican Library, 1971.

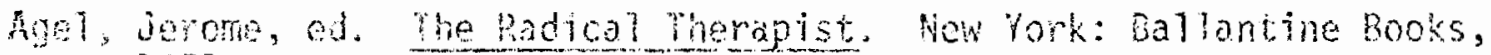
1971.

- ed. Fough Times. Nelv Yon Bablantine Books, 1973.

ATien, Fancla. Free Space: R Perspective on the small Group in homen's

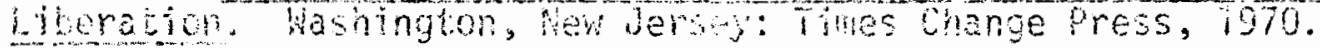

Anderson, balt. "Ereakng out of the Establichment lise." Human Behavion Decenter 1973 , pr. i0-16.

Anthony: Hable "gpan Letier to Psychiatrists." Radical Theraoist ? (Aucus Septomber 1970): 8 .

April. "ove"t Secua Discrimination Against Women in Psychological Contexis: As Gients," Pittsburgn: Kon, [1972].

Ash, Milued. "Freud on Ferintine identity ard Female Sexuality." Psychiaty 3t (Auqust 197) : $322-27$.

Association for Wonen psychologiets. "Peychology and the liew loman: Stathent of the Association of Women faychologists to the

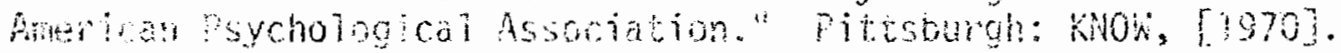


Barbach, Lonnie Garfield, Fon Yourself: The fuifinent of fenale Sexdality. Garden City, Neu York: Dowbeday ond Cumpany, Inc. 775 .

Bardick, Jucith $M$. "Her Body, the Battleground." The Fende Exgerlerces pp. 10-76. Edited by Carol Tavis. Dei Kar, Carfonnia Commo cations Research Macnines, Inc.; 1973.

Dardwick, Judith M. and Douvan, Elizabeth. "Ambivatence: The Socialization of Women." In Womar in a Sexist Society, pp. $224-241$. Edited by Vivian Gornick and Bartaro K. Wom. Nev York: Kew Americâr, Library, 1977.

Bardwick, Judith M., ed. Readings on the Psychology of Wonen. Haw rork: Herper and Row, 1972.

Barrett, Carol 3. et a!. "Ymplications of Women's Literation and the Fure of Psychotherapy." Psychotherapy: Theory. Resecich and Practice 2 (Spring 1974): 17-15.

Bart, Pauline. "Depression in Midole-Aged Wonen." in Woman in Sexst Society, po. 163-186. Eajted by Vivian Gornick and Earbara K. Woren. New York: New Anerican Library, 1977a.

Bart, Pauine P. "The Myth of a Value-Free Psychotherapy." In The Sociolog' of the Future, pp. 113-159. Eatted by wendeli beti and James A. Mau. New Tork: Russell Sage Foundation, IG7lb.

"Although We Are Angry, We Are No Longer Mad." Rough Times

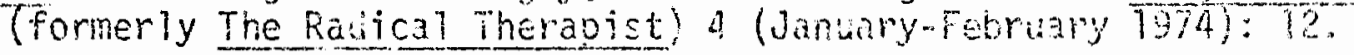

Beavroir, Simene de. The Second Sex. New York: Bantam Eooks, 1952.

Beck, Asion ?. and Greenberg, Rutn i. "Cognitive Therapy wich bepressed Wonen." In Women in Theray Men Psvchotherapies for a Chenging. society, pp. T13.131. Edited by Viofet Franks and Vasant Burte. New York: Brunner/Paze], 1979.

Becker, Howard s. "Whose Side Are We on?" In Qual tative Methodology: Fivsthan Inwivement with the social Wor Td, pp. 75-25. Edited by Whiton J. Filstead. Chicago: Warkhan hubishing Conpany, 7970 .

Becker, Hovard S. and Greer, Blanche. "Partictiat observation and intervewing: A Comparison" and "Participant Observtion and Interviewing: A Rejoinder." In Gualitative Mechodology. Finthand Invo? ventent with the Social Wor Th. pp. 133-152. Edited by Witian J. Fistead. Chicago: Markhan fublishing Company, 1970.

Becker, Marilyn and Krakauer, Alice. "Poltitcs of Themay for Women." Lcinen: A burral of Liberation 3 (?973): 2.9. 
Bees?y, Mary 6. "Crittoal Evaluations. Modern boran: Implications for Psychotherapy (i. Psohotherapy and Evolving Soctal-Sexual RoTes)." Conadian isyoliatric Associetion Jounch 18 (Fenuary 1973 ): $83-84$.

Ben, Sandra L. and Ben, Daryl 3. "We're All Unconscious Sexists." Psychology Today, Noverber 1970 , pp. 22-26, 116-116.

Benaro, Shinley. "Aggression in homen." Radical Therapist 1 (DecenberJamary 1971 ): 5 .

Blun, Fred H. "Geturg Individe to Give Infomation to the outsider." In Gualitative Methodelogy: Firsthand Irvolvenent with the Social

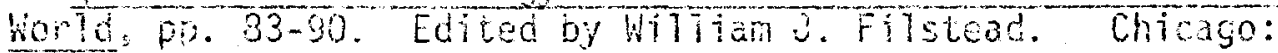
Mrkam Puotishing Company. 1970.

bouman, Bonnte. "The Feminist Answer to Sexist Therapy." Unpublished japer, University of Chicago, Decenter 1973.

Bometi, Deboroh, eu. Consciousress-Beising Hardbok. Los Angeles: los Angeles Not Conscionensos-käsing Commitee, 1979.

Erien, Lois and She?don, Synthia. "Gecait Therapy and Women." Urpulished aticie, Sar Franciso, ig75 Schoculed for publication in Tominist Tharepy. Edred by biane carter. Springfield, IThois: Charies C Thomas Compary, forthcoming.)

Brodsky, iniette. "The Consciousness-Paising Group as a Model of "hiarapy for homen." Psycotnerapy: Theory, Research and Fractice 10 (Spring 19\%3): 24.29 .

ed. "The Feninist Therapy Roster of the Association for Wumen in Fyclology." Fittsburgh, Kow: [197i-72].

Erogan, Gatherine tee. "Changing Perspectives on the Role of Women." Sith Collede Studies in Social bork 42 (Fetruary 1972): 155-173.

Erovoman, thye k. et al. "Sex-Rcle Stereotypes: A Current Appraisa?." Journe of Socta] Issues 23 (No. 2, 1972): $59-78$.

- "Sex Role Stereotyces and CTinical Judghents of Mental Health." Jourra of Consuiting and Cinica? Psychology 34 (February 1970): $1 . .7$.

Brown, Judith. "Fentirisw and Its jmplications for Therany." Radical Theragy (Aprit-ina 1970): 5-6.

Erown, Phi?. "Male Suprenacy in Freud." Radica? Therapy? (September" $1971): 2-4$

Buntle, Vasanti; Whit?ock, ooris; and Frank, Violet. "Modification of Low Self-isteen ir Women Alcoholics: A Behavion Treatment Approach."

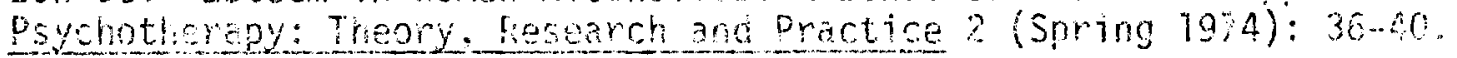




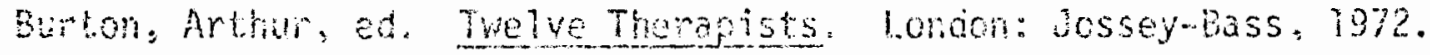

Bucler, Panela E. "Assevive Training: Teaching Women Hot to Discrinarate Against Thonselves." EKIO Accession tEO086103, 1973.

Carter, Char?ene A. "Advantages of Boing a Woman Therapist." Psycho.. theragy: Theory. Research. Practice (Winter 1971): 297-300.

Cherniss, Cary. "Persurality and Ideology: A personological Study of Women's Lberation." Psycniatry' 35 (May 1972): 109-25.

Cheslew, Phylis. "fen brive funen Crayy." in The Fomale Experienos, pp. 79-33. Foited by Carul Tevris. Del Mar, Sifronia:

Comunications reserrch machines, inc., 1973.

- Honen and Madness. Msi York: Avon Books, 1972.

"Wonen as Psychiatio and Pachotheraped ic Patients," Jeurnal of Marioge and tit Eaniy 33 (Novemb. 1973 : $746-59$.

Christeve, Jackie. "Anger...What to Do with It?" Ri: A Loumal of

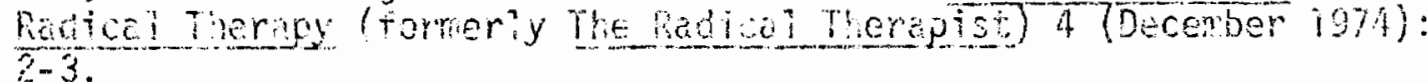

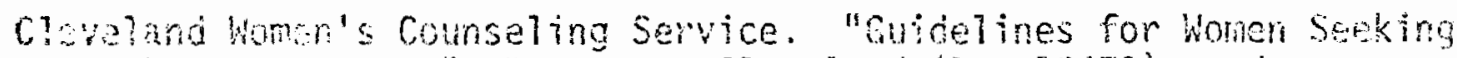
Psychotherapy." Brochure, Cleveiand (Box 78472), n.d.

Cobola. Sie; Etta, Barbara; and Florika. "An Articie on Women's Liberation and the Small Group Process." Libera, Summer 1972. pip. $3-7$.

Collins, Alice H. Haturai Delivery Systers: Accessible Sounces of Power io llental Health." American uumal of or hopsychiatry 43 (janiary 1973): $46-52$.

Cock, Gombara and Stome, Deverly. Counseling Women. Boston: HoughtonMiffin company, 1973.

Cumirgs. Eian, et a]. Assert Your Self. Seattle: Seatte-king county $10 \mathrm{n}, 7974$.

Cumings, lucy. "Wot Fsycriatuists Say Acout Women's Liberation." Fanily beekiy. July 2,1972, . 4.

Dejanikus. Taso ind poliner, Fian. "Feminist Counseling." Rough Tines

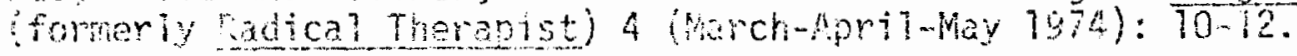

Demperoifr, Jud A, "Development and Vaidation of a Feminism Scale." Psychojogical Peports 31 (Afril 1974a): 651-57.

"Some Correlates of Feminism." Psuchojogical Reports 34 (Apri) 79740$): 071-76$. 
Doubscher, Irwin. "Lowhing Eackvards: Case Studies on the Progress or Pethodology in Sochologica? Reseach." in Qualitative Gethodology:

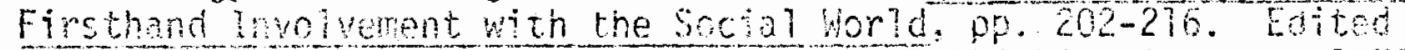
by whilam a. Fhsted. Chcago: Warkan Publishing company, 1970.

Diggs, thizaboh. "What is the Uonen's Movenent?" Wonen: A joume? of liberation $2(1972): 10-13$.

Vixon, Marlene. "Public Iceology and the class Composition of Worner's liberation (1966-1969)." Reply by fin Letter and Bair L. Gillespie "A. Foninist Repiy: Ue Dery the Aliegiations and Defy the Allegator." Eerkeley Jomrnal of sociology 16 (1971-72): 143-79.

- "The Rise of Women's Liberation." In Readings on the psychology of Wonen, po. 187-191. Edited by Judith M. Bartiwick. Wew Tor.: harper and Row, 1972 .

Doencke, Mol1y M. "The Wonen's Liberation Movement and Identity Change: An Urban Pilot Study." Unpublished Master's thesis, Portland State Universtoy, Hovember 1972.

Doherty, Mary Austin. "Sexual Bias in Personality Theory. "Counse?ing Psycholecist a (10. 1, 1973): $67-74$.

Dubitzky, Millie. Speech given at Conference on bomen's Mental healil, San Francisco, January 24, 1975.

Sibois, Garbara. Initial questicmaire. Ph.o. dissertation in process. Harvard University, Cambridge, Massachusetts, 1975.

Duxbury, Hickey and Heaney, Lois. Speech given at Conference on Wonen's Menta le? th, San Francisco, January 24, 1975.

Eastman, Paula Costa. "Consciousness-raising as a Resorialization Process for Women." Snith Col lege Studies in Socia? Work 43 (June 1973): $153-83$.

Edwards, Cwenystis Cohen, Dale; and Zarrow, Maria. "Feminist Therapy Conference $1975 . "$ Bt: A Journe? of Radical Theragy (fomeriy

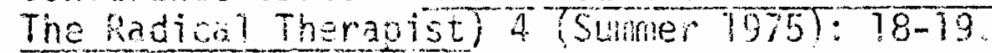

Etzkowitz. Shari. "Sexina and Psychotherapy." Radicai Therapy? (Aprilidy 1971): 2.

Fabrikant, Senjamin. "The Psychotherapst and the Fende Patient: Perceptions, Misperceptions ind Change." In Women in Tremapy: Wew Pshcyotherapies for a chaving Society, pp. 83-709. Edited by Violet Franks and Vasant Burtie. Hew York: Brumermazel, 1974.

Fashing, Katis. "An Energing Theory of Feminist Counseling." Unmublished paper, Albugerque, Stimer 1974. 
Feldman, Marsha; Cabel, Emily Jean; and Taylor, Fran. "A Talk with Pryllis Chesler." Second wave? (1973): 7-10.

Feminist Counseing Collective. "Feminist Psychotherapy: A New Method for Fighting the Social Conirol of Women." American Journal of Orthopsychiatry 44 (March 1974): 187-88.

Fide?1, Lindas. "Put her Down on Drugs: Prescribed Jrug Usage in Women." Pittsburgh: KNow [1973].

Fields, Rona M. "Psychotherapy: The Sexist Machine." Pittsburgh: Klvow, n.d,

Filstead, William J., ed. Qualitative Methodology: Firsthand invoivenent with the Social World. Chicago: Markham Pubiishing Company, 1970.

Firestone, Shulamith. The Dialectic of Sex: The Case for Feminist Revolution. New York: Bantam Books, 7970 .

Fodor, Iris G. "Sex Role Conflict and Symptom Formation in Nomen: Can Behavior Therapy Help?" Psychotherapy: Theory, Research and Practice 2 (Spring 1974a): 22-29.

Fodor, Iris Goldstein. "The Phobic Syndrome in Women: Implications for Treatment." In Women in Therapy: Hew Psychotherapies for a Changing Society, pp. T32-63. Edited by Violet Franks and Vasanti Burtie. New York: Brunner/Mazel, 1974 b.

Franks, Violet and Burtle, Vasariti, eds. Women ir Therapy: New Psychotherapies for a Changing Society. New York: Brunner/Mazei, 1974.

Freeman, Jo. "The Social Construction of the Second Sex." Pittsburgh: kHOW, 1970.

- "The Women's Liberation Movement: its Origins, Structures and Ideals." Pittsburgh: KNOW, 1971.

Friedan, Betty, The Feminine Mysique. New York: De1l Publishing Compariy, i963.

Gardner, bo-finm. "Sexist Counseling Must Stop." Personnel and Guidance Jourral 49 (May 1971): 705-713.

Gersor, Bartara. "Consciousness-Raising Groups with Elementary School Girls: A Case Study." Psychotherapy: Theory, Research and Fractice 2 (Spring 1974): $30-35$.

Giiran, Richard. "The Femlib Case Against Sigmund Freud." New York Times Magzine, January 3i, 1971, pp. 10-11, 42-47.

Gilmore, Susan. "If You're Depressed, You're Probably Sub-Assertive." In llomen on the Move, pp. 15-19. Edited by Jean Ramage Leppaluote. Pittsburgh: Whon. 1973 . 
Giaser, Barney a. and Straiss, Anse?m L. "Discovery of Substantive Theory: A Basic Strategy Underiying Qualitative Research." In Qualitative Methodology: Firsthand Involvement with the Social World, pp. 288-304. Edited by Wit7iail J. Filstead. Chicago: Markham Publishing Company, 1970.

Goidberg, Phillip. "Are Women Frejudiced Against Women." Trans-action 5 (Aprii 1968): 28-30.

Gornick, Vivian. "Consciousness." In Readings on the Psycholouy of llomen, pr. 170-77. Edited by Judith M. Bardwick. New York: Harper and Row, 1972.

Gornick, Vivian and Moran, Barbara $K_{0}$, eds. Woman in Sexist Society: Studies on Poier and Powerlessness. New York: New American Library, 1977.

Gove, Walter R. and Tudor, Jeannette F. "Adult Sex Roles and Mental 17 iness." In Changing Womeil in a Changing Society, pp. 50-73. Edited by Joan Huber. Chicago: University of Chicago Press, 1973.

Greer, Germaine. The Female Eunuch. New York: McGraw-Hi11, 1970.

Haan, Norma and Livson, Norman. "Sex Differences in the cyes of Expert Personality Assessors: Blind Spots." Journal of Personality Assessmient 37 (October 1973): 486-92.

Halleck, Seymour. The Politics of Therapy. New York: Science House, Inc., 197!.

Hanisch, Carol. "The Personal Is Political." Radical Therapist 1 (JuneJu?y 1970): 17.

Hartman, Sylvia. "Princess Valium Meets Shrinkthink: Cashing In on Sexisil in Psychiatry." Radical Therapy 1 (August-September 1970): i6-17.

Heide, Wilma Scott. "The Reality and Challenge of the Double Standard in Merital Health and Society." Pittsburgh: KNOW, n.d.

Henley, Narcy. "The Poittics of Touch." Pittsburgh: kNOW, [1970]. "Rejources for the Study of Psychology and Women." RT: A
Journal of Radical heray (fomerly The Radical Therapist) 4
TDecember 1974): 20-2.

- "Tracking the Elusive Female Psyche: Recent Eooks on Psychology and Wumen." Rough Times (fomerly The Radical Therapist) 3 Part I (rebruary-ifay 1975): 15-17; Part if (May 1973): 8-10.

Hermes, demette. "On Radical Theramy." Radical Therapy 1 ICecemberJnvary 197 !): $2-3$. 
Hochschild, Arlie R. "A Review of Sex Role Research." In Changing Womar in a Changing Society, pp. 249-67. Edited by Joan Huber. Chicago: University of Chicago Pross, 1973.

Horrer, Matina S. "A Bright Woman is Caught in a Double Bind." Psychelogy. Today, Novamber 1969, pp. 36-41.

- "The Motive to Avoid Success and Changing Aspirations of

College Women." In Readings on the Psychology ct bomen, pp. 62-67.

Edited ly Judich M. Bardwick. New York: Harper and Row, 1972.

Howard, Ephram M. and Howard, Joyce L. "Women in Institutions: Treatment in Frisons and Mental Hospitals." Women in Therapy: New Psychotherapies for a Changing Society, pp. 357-82. Edited by Wiolet Franks and Vasanti Burtle. New York: Brunner/Maze1, 1974.

Huber, Joan. Changing Women in a Changing Society. Chicago: University of Chicago Press, 1973.

Hunter, Alexandra. Speech given at Conference on Women's Mentil Health, San Francisco, January 24, 1975.

Jacobson, Aileen. "The Feminist Therapists." Washington Post, September 9 , 1973, pp. Cl, C5.

Jakubowski-Spector, Patricia. "Facilitating the Growth of Women Through Assertiveness Training." Counseling Psychologist 4 (No. 1, 1973a): $75-86$.

- An Introduction to Assertive Training Procedure for women. Washington, DC: American Personnel and Guidance Association, 1973b.

Janekay, Elizabeth. Man's World, Woman's Place. Hew York: Dell Dublisting Company, 1977 .

Kaplow, Susi. "Getting Angry." Notice From the Third Year: Women's Liberation (1971): 15-17.

Keiffer, Mirian G. and Cullen, Dallas il. "Women Who Discriminate Against 0ther Women: The Process of Denial." Pittsburgh: KNow, n.d.

Keniston, Konnerh. Young Raticais: Notes on Committed Youth. New York: Harcount, Brace and World, 1968.

- Youth and Dissent: The Rise of a New Opposition. New York: Harcourt, Brace and Jovanovich. Inc., 1971.

Kerr, Carmen. "Feninist Sexual Therapy." Issues in Radical Therapy 3 (Winier 1975): $6-10$.

Kirsh. Barbara. "Consciousness-Raising Groups as Therapy for Women." In Women in Therapy: New Psychotherapies for a Changing Society, pp. 320-3ju. Edited by Violet Frarks ard Vasanti Burtle. New York: Brunner/Maze1, 1974. 
Kcadt, Anne. "The Myti of the Vaginal Orgasm." In Up Against the dall, Motherfucker: On Vomen's Liberation, pp. 167-175. Edited by Elste Adahs and Mary Louise Biscoe. Beveriy Hilis, California: Glencoe Press, 1971 .

Kontopoulos, Kyriakos M. "Women's Liberation as a Social Movement." In Toward a Sociology of Women, pp. 354-67. Edited by Constantina Safilios-Rothschild. Lexington, Massachusetts: Xerox College Press, 1972.

Krakauer, Alice. "A Good Therapist is Hard to Find." Ms., October 1072, pp. 33-35.

Krause, Charlotte. "The Femininity Complex and Women Therapists." Journal of Marriage and the Family 33 (August 1971): 476-82.

Krieger, Mari. "Consciousness-Raising and Gestalt for Women: A Synthesized Approach." Unpublished Master's thesis, Californio State College, Sonoma, California, 1974.

Kronsky, Betty J. "Feminism and Psychotherapy." Journal of Contemporary Psycinotherapy 3 (Spring 1971): 80-98.

Laws, Judith Long. "The Social Psychoiogy of Wonen: Shibboleths and Lacunat." Pittsburgh: KNOW, n.d.

Lazarus, Arnold. "Women in Behavior Therapy." in Women in Therapy: New Psychotherapies for a Changing Society, pp. 217-246. Edited by Violet Franks and Vasenti Burtie. New York: Brumer/Maze1, 1974.

Leah and Mary Jane. "Thinking About Psychiatry." Vomen: A Journal of Liberation 2 (Uinter 197i): 50-52.

Lemiar, Hannah. "What Happens in Feninist Therapy." Paper presented in the Symposium, "Feminist Therapy: In Search of a Theory," Corvention of the Americai Psychological Association, New orleans, 1974.

Lindsey, Karen. "On the Need to Develop a Feminist Therapy." Rough Tires (formerly Radical Therapist) 4 (September 1974): 2-3.

ina ilnot, Alice. "The Paranoia Proy." Rough Times (fomerly Radical Therapist) 3 (April-May 1973): 4.

Marone, Joarire. "Can Therapy be Liberating to Women." Off Our Backs, Aay 6, 1971, p. 19.

Mander, Anica Vesel and Rush, Anre Kent. Feminism as Therapy. New York and Berkeley: Random House and Bookworks, 1974.

Wariechild, Diane and Wiliams, lane. "Feminist Therapist as Midwife." RI: A Jownal of Padical Therapy (fomerly Tive Radical Therapist) T (Decomber 1974): 6 . 
Matchows, Esther, et al. Counseling Giris and Women over the Life Span. Washington, D.C.: National Vocational Guidance Association, 1972.

Meador, Betty; Solomon. Eveiyn; and Bowen, Maria. "Encounter Groups foy Women Only." In ilew Perspectives on Encounter Groups, pp. 33543. Edited by Lawrence N. Solomon and Betty Berzon. New York: Jossey-Bass, 1972.

Menaker. Esther. "The Therapy of Women in the Light of Psychoanalyitic Theory and the Emergence of a New View." In Women in Therapy: New Psychotherapies for a Changing Society, pp. 230-62. Eutited by Violet Franks and Vasanti Burtie. New York: Brunner/Mizel, i9\%.

Milgran, Stanley. "The Small World Problem." Psychology Today, May 1967, pp. 60.67 .

Mijler, Jean Baker, ed. Psychoanalysis and Women. Baltinore: Penguin Books, 1973.

Mil?er, Nadine. "Letter to her Psychiatrist." In Radical Therapist, pp. 139-43. Edited by derome Agel. New York: Billantine Books, 1971.

Millet, Kate. Sexual Politics. New Yoik: Avon Books, 1969.

Mitchell, Juliet, Psychoanalysis and Feminism. New York: Random House, 1974.

- Voman's Estate. New York: Vintage, 1971.

Morsan, Robin, ed. Sisterhood is Powerful: An Anthology of Writinas from the Women's Liberation Movement. New York: Vintage Books, 1970 .

Moulton, Ruth. "Psychoanalytic Reflections on Women's Liberation." Contemporary Psychcanalys is 8 (No. 2, 1972): 197-223.

Munter, Pam. Speech given at Oregon Association of Professional Psychology meeting, Portland, Oregon, March 29, 1975.

Nadelson, Cärol M. "Adjustment: New Approaches to Women's Mental Heaith." In The Anerican Wonan: Who Will She Be? pp. 21-36. Edited by Mary L. McBee and Kathrun A. Blake. Beverly Hilis: Glencoe Press, 1974.

Naffziger. Claudeen. "Women and Anger: Alternatives." In women on the Move: A Feminist Perspective, pp. 5-14. Edited by Jean Ramage leppalisoto. Pitusburgh; kNow, 1973.

Neulinger, John. "Perceptions of the Optima?iy integrated Person: A Redefinition of Mental heaith." Procedings of the 75 th fnnual Convention of the American Psychological Association (1968): $553-5 t^{2}$. 
Nowaki, Christine M. and Poe, Chanles A. "The Concept of Mental health as Related to the Sex of Person Perceived." Journal of Consulting and Clinical Psychology 40 (February 1973): 150 .

Osborne, Susan M. and Harris, Goria G. Assertive Troining for Women. Springfield, Ilinois: Charles C. Thomas Publishing Company, 7975.

Osmond, Humpiry; Franks, Violet; and Burte, Vasanti. "Changing Views of Women and Therapeutic Approaches: Solne Historica? Considerations." In Women in Therapy: New Psychotherapies for a Changing Society, $\mathrm{pp}, 3-24$. Edited by Vicet Franks ard Vasanti Eurtie. New York: Brunner/Mazel, 1974 .

Parun, Phyllis. "Padical Femaie Psychology: Two Stätements." Radical Therapist I (December-January 1971): 5.

Payne, Carol. "Consciousness-Raising: A Dead End?" Notes from the Third Year: Women's Liberacion (197i): 99-100.

Pendergrass, Virginia E. "Women as Clinicians in Private Practice." American Psychologist 29 (Ju7y 1974): 533-36.

Perlstein, Marcia. Speech given at Conterence on Womeri's Mental Health, San Francisco, January 24, 1975.

Perry, Renee. "More Conference: A Second View." Plexus, February 1975, p. 11.

Pierce, Carol. "Women's Personal Issues." Second Wave 3 (Spring 1974): $29-37,40$.

Pincus, Cynthia; Radding, Natalie; and Laurence, Roberta. "A Professional Counseling Service for Komen." Social Work 19 (March 1974): 187-95.

Pines, Sara. "Radical Psychotherapy in Private Practice." Radical Theropy 2 (December 1971): 6 .

Polk, Barbara Bovee. "Women's Liberation: Movement for Equality." In Toward a Sociology of Women, pp. 321-30. Edited by Constantina Safilios-Rothischild. Lexington, Massachusetts: Xerox College Press, 1972.

Polster, Miriam. "Wonen in Therapy-A Gestalt Therapist's View." In women in Therapy: New Psychotherapies for a Changing Society, pp. 247-83. Edited by violet Franks and Vasanti Burtie. New York: Brunrer/Mazel, 1974.

Raffini, Mary. "A Feninist Aiternative: The Elizabeth Stone House." Ri: A Journal of Radical Therapy (formeriy The Radical Therapist) 4 (spring 7975): $12-15$. 
Redscockings. "What You Can Do." In Radical Therapist, po. 169-72.

Edited by Jerome Age:. Nen rork: Ballantine Books, 97 .

Rice, Joyk. and Rice. David a. "Implications of the Women's Liberation Movenent for "aychotherapy" Americar journal of Psychiatry

130 (February 19?3): $191-96$.

Riess, Remara. "Hew Viewpotnts on the Femele Homosexual." In Women

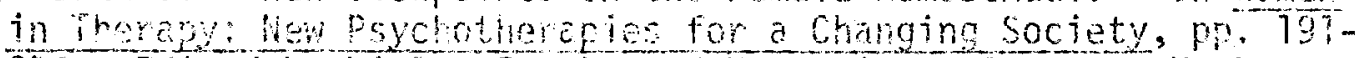
2). Edtad by Wolet Frask and Vasanti Burtie. New York: Brunothaze?, 1974 .

Rojas, Marion. "A Jungian View of the Feminine." Ploxus, October 1974 , p. i?.

Rolphe, Anne. "What Women Psychoanalysts Say About Women's Liberation." New York Times Magazine, February 13, 1972, pp. 63-70.

Rosenkrantz, Peul, et al. "Sex-Role Stereotypes and Self-Concepts in college Studerts." Journal of Consulting and Clinical Psychology 32 (jure 1960): $287-95$.

Rosenthal, Robert, et d]. "The Language Without Words." Psychology Today, September i974. pp. 64-68.

Rush, Ame Kent. Getting Clear: Pody Work for Women. New York and Eerkeloy: Pandon Houge and Bonkwhs, 1973 .

Rush, Florence. "Notes Fron a Social worker." Radical Therapist? (Septeribur 1971): 13-14.

Schiossberg, Nancy. "A Framework for Counseling Women." Personnel dnd Guidance Journe 5 (0ctober 7972 ): $737-43$.

Schlossbang, Nancy $K$ and Pietrofesa, John 3. "Perspectives on Counseing Bias: Implications for Counseior Education." Courseling Bsyciology of (1io. 1, 1973): 44-53.

Schwatz, liary $c$. "Importance of the Sex of the Worker and the client." Socia iork is (March 1974): 172-86.

. "Sexism the Social Work Curriculum." Journal of Education for Social bork 9 (Fa1) 1973); 65-7(i.

Seeman, Mary V. "Critical Evaluations. Modenn Women: Implications for Psychotherapy (II. Womian's Adjustment to Being Modern). "Canadian Psychiatric Association Journal is (February 1973): 84-85.

Seidenterg, Robent. "redipus and Male Supremacy." Radical Therapist 1 (Deconber-ianuary 1971 ): 9. 
Sharness, Natalia. "Images of Homen: Past and Presont, Overt and obscured." Anenical Joumal of Psychotherapy 23 (January 1969): 77-97.

Sherfy, Mary Jare. The Nature and Evolution of Female Sexuality. New York: Rániom House, 1056.

Shinlas, Audrey. "An Interyiew with Audrey Shimkas on Feminist Therapy." Piexus, October $1974, \mathrm{p} .12$.

Siassi. Iradj. "Psychotherapy with bonen and Men of Lower Classes." In jomen in Therapy: New Psychotherapies for a Changing Society. pp. 383408. Edited by Violet Franks and Vasanti Burtle. New York: Brumerimaze1, 1974.

Silveira, Jeanrette. "The Effect of Sexism on Thought: How Male Bias hurts Psychology and Some hopes for a boman's Psychology." Pittsuburgh: kNOW, [1972].

Sohl: Kay. "Transition Houses." Portland Scribe, December 21,1974 , pn. $6-7$.

"Special Symposium: The Mental Health Movement Meets Women's Lib." Mental Hygiene 55 (January 1977): $1-9$.

Staines, Eraham; Tavris, Carcl; and Vayarathe, Toby Epstein. "The Queen Eee Syndrome." In The Fenale Experierice, po. 63-66. Edited by Carol Tavris. Del Mar, Caifornia: Communications Research Machines, lnc. : 1973.

Steinew, Claude. Scripts People Live: Transactional Analysis of Life scripts. New York: Crove Press, 1974.

Stetmann, Fine. "Cultural Values, Femaie Role Expectations and Theraneutic Goais: Research and Interpretation." In Women in Therapy: New Psychotherapies for a Changing Society, pp. $51-82$. Edited by iolet Franks and Vasanti Eurtle. New York: Brumerthaza], 1974.

Stephenson, Susan. "Mocern Woran: Implications for Psychotherapy." Canadion Psychiatric Association Journa 18 (February 1973): $79-32$.

Stevens, Barbara. "The Psychotherapist and Vomen's i.iberation." Social Wort 16 (july i971): 12-13.

- The Soxually oppressed Maje." Psychothenoby: Theory, Research 3nd Practice 2 (Spring 1974): 16-2!.

Strouse, Jean, ea. Women in Ansysis: pialoaues on Psychoanalytic Views of femininity. Rew York: urosinar Putishers, is74. 


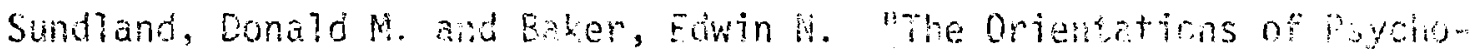
therapists." Journal of Consulting Psychology 26 (June 906 ): $20:-212$.

Symonds, Alexandia. "A Discussica of Cr. Moulton's Articie, "Psychoanalytic Reflections on Women's Liberation. "Contenpcrarv Psychoanays is 8 (No. 2, 1972): $224-228$.

Szyrynski, "ictor. "Criticel Eva?lutions. Modern Wonan: Mmp? icetions for pychotherapy (ITi. The Therapist's Attututes ant lalues)." Canadian Psychiator Association jounga 18 (February 1073): 85-36.

Tavris, Carol. "Woman and Man." Psychology Today, March 1972, pp. 57-64, $82-35$.

Tax, Meredith. Wuman and Her Mind: The Story of DajyLife. Sonerville, Massachusetts: New England pree Press, 1970.

Tennov, Dorothy. "An Aiternative to Therapy." Aurord, issue 10. 4. 1974, pp. 5-8.

- "Feninism, Psychotherapy, and Professionalism." Journal of Contemoorary Psychotherapy 5 (Summer 1973): 107-11i.

- "Open Rapping." Pittsburgh: KNOW, n.d.

Tennov, Dorothy and Payne. Heien. "Setting up a Selfwelp Counseling $\left(C_{1} C_{2}\right)$ Project: Suggestions and Guidelines." Unpublished paper, Stratford, Connecticut, 1974.

Thomas, Gretchen. "Getting What You Need Whout Adapting." Fadical Therapist 2 (october 1971): 20.

Tiedt, Iris M. "Realistio Counseing for High School Girls." The School Counse]or 79 (May ig72): $354-56$.

Torrey, Jane "1. "Psychoandysis: A Feminist Revision." Pittsburgh: Rowow, $[1977]$.

Travers, Jeffrey and Milgram, Stanley. "An Experimental study of ti: Sinall Worid Problem." Socionetry 32 (December 1969): 125-43.

Tresemer, David. "Fear of Success: Popular, but Unoroven." In The Female Experience, pp. 58-62. Edited by Carol Tavis. Det Mar. Caltionna: Commutications Research Marhines. Inc. $\$ 973$.

Trout, Emar. "Women in Counse?ing." Collony, onuary 1973, np. $29-31$.

Valliant, Am. "Women as Hea?ers." RT: A Joural of Radical Therapy

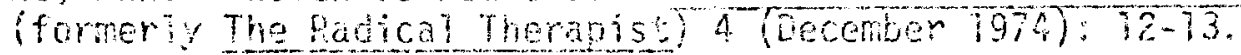


Vance, Dot. "Offing Piggery in Vonen's Groms." In Räbel Therapist. pp. 192-94. Edited by Jerome Age?. Hew Kork: Ballanthe book, $1971 \mathrm{a}$.

. "On Not Stroking Deperciency." Radical Therapist 2 (October (9776): 14.

"Reclaining Our Birthright." Radical Therapist 2 (October" 197ic): $21-22$.

- "Taking Care of Business as a Group Leader." Radical Therapiet: (October 1971d): 14-15.

Vidich, Archur 3. "Participart Observation and the Collection and Interpretation of Data." In Qualitarive Methodolowy: Firsthad Involverent with the Social world, po. 164-73. Edited by mintan J. Fistead. Chicago: Markham Pubi ishing Company, $19 \%$.

Wa!ker, Lee. "A Quick Rundown on Feminist Consciousiess-Raising Groups." Pittsburgh: KNOW, n.d.

Haistedi, Joyce Jennings. "The Aratomy of dporession: A Feminist Anciysis of Psychotherapy." Pittshurgt: KNOW, 197.

- The Psychology of Women: A Partially Amotated Bibliography. pittsburgh: KuW, 1972.

Webbink, Pat. "A Feminist Trerapist." of Our Backs, Februsry-ifarch 1973, p. 22.

"Therapist Turned Woman." Rough Times (fomerly The Radical Therapist) 2 (April 1972): 8.

Weissman, Myrna $M$. and Paykei, Eugene S. The Depressed Wonan. Chicago: iniversity of Chicago Press, 1974.

Weisstein, Nami. "Kinde, Kuche, Kirche' As Scientific Law: Psychology Crinsiructs the Female." In Sisterhood is Powerful, pp. 205-220. New York: Vintage, 1969.

Wesiey, Carol. "The Homen's Movonicnt end Psychotherapy." Social Work 20 (March 1975): 120-24.

Westerveit, Esther Manning. "A Tide in the Affairs of Women: The Psychoiogica? Impact of Eeirinism or Edurated inmen. "Coulseling Psychologist 4 (No. $i, 1973$ ): $3-26$.

White, Peggy and Starr, Goode. "Perspectives on our Movenent: The Smalf Group in Women's Liberation." Women: A Journal of Liberation 1 (Fa) 1969): $56-57$. 
Whitely, Rita M. "Women in Goups." Counseling Psychologist 4 (Mo. 1, 1973): $27-43$.

Withers, Jean. "Don't Taik While I'm Interrupting," Ms, , Narch 1975 , pp. 106-109.

Wolman, Caro?. Speech given at Corference on Women's Mental heath, San Francisco, January 24, 1975.

Women in Transition. Women's Surviva? Manual: A Feminist Hancbok on Separation and Divorce. Phitadelphia: women in Transition, 1972.

- "Before You Choose a Therapist." Pittsbungh, KNow, n.d.

"Women in Transition." Women: A Journal of Liberation 2 (1972): 14-16.

Wortis, Helen and Rabinowitz, Clara, eds. The Women's Movenent: Social and Psychological Perspectives. New York: Halsted Press, 1972.

Wyckoff, Hogie. "Between Women and Men." Reprinted from Issues in Radical Therapy i (Winter 72-73): n.p.

- "Froblem Solving Groups for Women." Reprinted from issues.

in Padical Therapy i (Winter 1973): n.p.

- "Radical Psychotherapy and Transactional Analysis in Wonen's Groups." Transactional fnaiys is Bullet in 9 (0ctober 1970: $123-33$.

"The Stroke Economy in Women's Scripts." Trensactional Analys is Journal 1 (Ju\}y 7971 ): $76-20$.

Yurmark, Judith. "The Role of Ulomen in Social Casevork Literature and its Relation to Psychoanalytie Theories of Female Psychology." Unpublished M.S.H. thesis, Smith College School for Social Vlork, Northampton, Massachusetts, 1972. Abstracted in Smith College Studies in Social Work 43 (1972): 83-84.

Zweig, MariTyr. "Is Vomen's Liberation a Therapy Group?" Radical Therapist 1 (August-Septeniner 1970): 7 . 


\title{
APPENDIX A
}

\section{COVER LETTER, FGR QUESTIONNAIRE}

\author{
2566 N.Vi. Love joy \\ Poriland, Oregon $\$ 7210$ \\ December 4 , 1974
}

1 am coing my thesis on feminist therany through the school of seciat work at fortlanu state University. That choice has grown out of my onn expariences and noeds. Baing in therafy myelt witt a mon ernscicids of faninist concerns was very ingutant for me. Currenily, 1 see or indrily momer, in the college's studsnt counseling center, snd en ettampling to bring to thet silvetion a similar consciousness. However, 1 foel a real reed to kno.t what other yomen ere thinking, directions they are moving, and ways they are inerging ineory and practice.

The thesis will be in tho parts: 3 litersture rovian and tha results of infervikwe with women in porilane, seatlle, and the Bay hrse who consider trexneives to de feminist therapists or counselors. Hy goal is not to test the valicity of feminist therapy or to compore feninist trerapists to other therapisis but to begin io craracterize feminist therapy as it now Exists.

Based on the thesis will be o stiorter paper which hopafully can serve as a self-eduedion toul for paopls who want to incorporate aspects of Feninist the:apy into theit sevinork. I also plan to send it to thase! inierviaw as a formi of feedback between us and anong those wemen 1 have contactied.

So thet 1 artually interview es wide and yet representefive a range of women as possible, I sm developing a "sample frome" of women who identify thenselves as feninist theropists and ore willing to be interviewed. The questionnaire on the next poge asks for the bockground information 1 need to seiect a sarple. Untike the questionnatre, the interview itself wili of printerly conceried with your practice ond your theory behind that practice. Vwaen and centers who have shared with me their reperral lists of therepists have asked for feedueck and andtionel nanes of and background iriforntefion on women in their ereas. I will te using the informetio you provice on these questionnaires ior that purpose as well.

I really do need your helo and cooperztion and hope in turn ther you wi:! wart to there what you are coinc. To meke whot i ant doing "researehvalie", it is imporiant that i receive replies fromeach of you. I would elso be verv inferested in receiving anything you may have written ebout mal you sre boing. fieaso relurn the questiontaire to me ir ihe enclosed emelope by becenter if. I aprraciate rour tsking the time to do this.

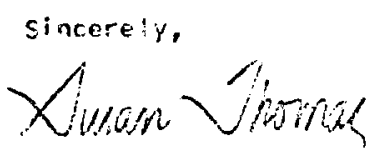


Several questionnaires are enchised virere 1 have know of people working tom gether. If there are not enough, numbered fisces of paper will york. it you do respond ior a group, please lisi al: names as wali as the crup name and irdicate diffarences among you where possicle. The questioniatre is siructured in moke is easier to till cut. I would welcome any empititicutions or coments in olaces wheri yuu Jon't feel "fit" by o setegory.

Hane $(\leq)$ :

Address:

Phore(s):

1. Do you consider yourseli to be a feminist therapist or counselor ll have no: as inced this furthe:, waniting your answer to rellect your own personel stanuar us and criterial

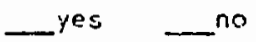

2. What is your general theorefical orientation, in addi tion to your feminism? lcheck all which apply!

Aclerion
assertive training
betaviorism
bicenergetics
co-sounseling
eciectic
Freudion

gesialt
humanistic
Jungion
Jurima!
prosychooynamic
Peichian
Rererian

TA

Lother (please specity)

3. How long have you been doing therapy llotal time, whether feminist or notl

4. What degree do you have?
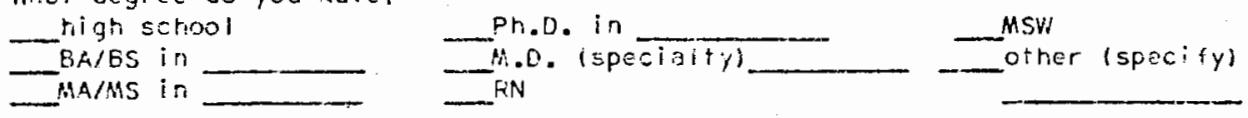

5. What is the focus of your practice? (check all which apply)

chiliren
adolescents
women
iesbian wonien
families
couples

women and men both
individuals
groups
Norkshops
training

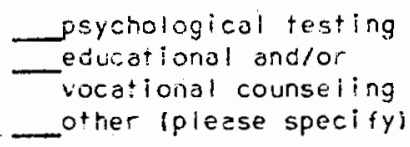

5. Are you

in frivate practice

employed by a public agency momer oi college or univ. faculty

7. Do you specialize in a particuiar area(s) or problem(s) member of a coilective erirolled in school other lplease specif $y)$

11 yes, what are hey?

8. Are you willing to be interviewed? _yes no lif no, please explain brief! 1

9. Are there orher women you know cf in your area who l couid contact? if so, llase ils! their nates, adaresses, ang phone numoers. 


\section{APPENDIX C}

LETTER OF ACKNOWLEDGMENT

2566 N.W. Lovejoy

Portiand, Oregon 97210

3 Fetruary 1975

I received the questionnaire you returned to me on feminist therapy and really appreciated your taking the time to fill it out. From the questioninaires returned and marked "yes," I chose a total of 20 women to interview. That was reai hard to do and I ended up having to be pretty random arid arbitrary. So, due to some vagary of fate, your name wasn't one of those that ended up in the "sample." Norietheless, I felt supported by your willingness to talk with nie.

Enclosed is the list I have gathered of those women who identified themselves on the questionnaire as feminist therapisis. I tried to include as much of what people said as possiole, and hope if you are on the list that you feel represented fairly.

Some of you have indicated an interest in receiving a copy of the shorter paper I'll be writing based on my thesis. I would be glad to share that with you, but for sheer financial constraints. However, if you want to send me 50\% to cover Xeroxing and postage, Ii 11. be glad to send you a copy when it's ready (probably in June but pernaps over the summer).

Again, thank jou for your participation.

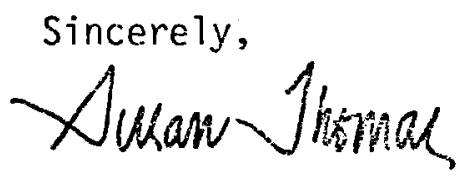




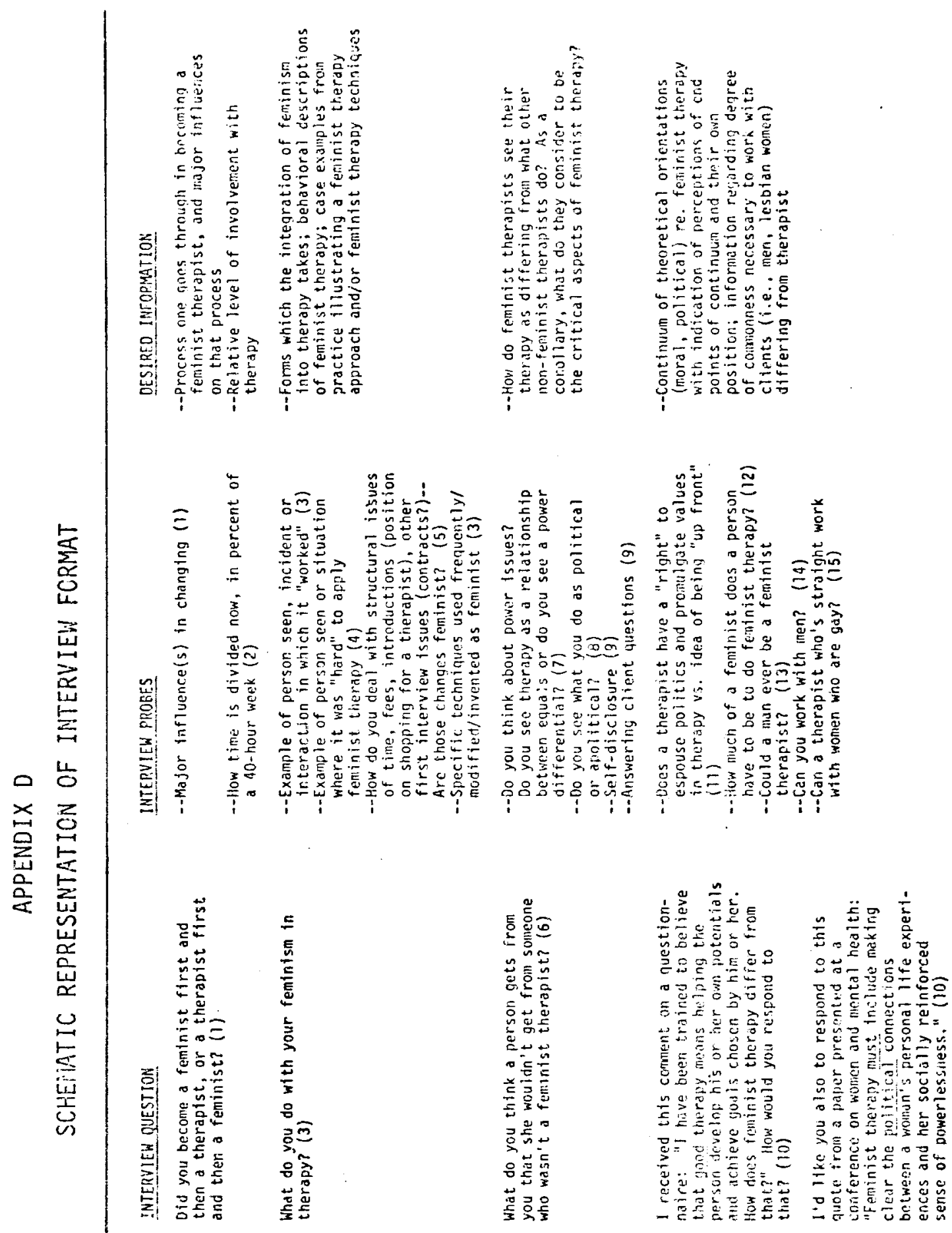



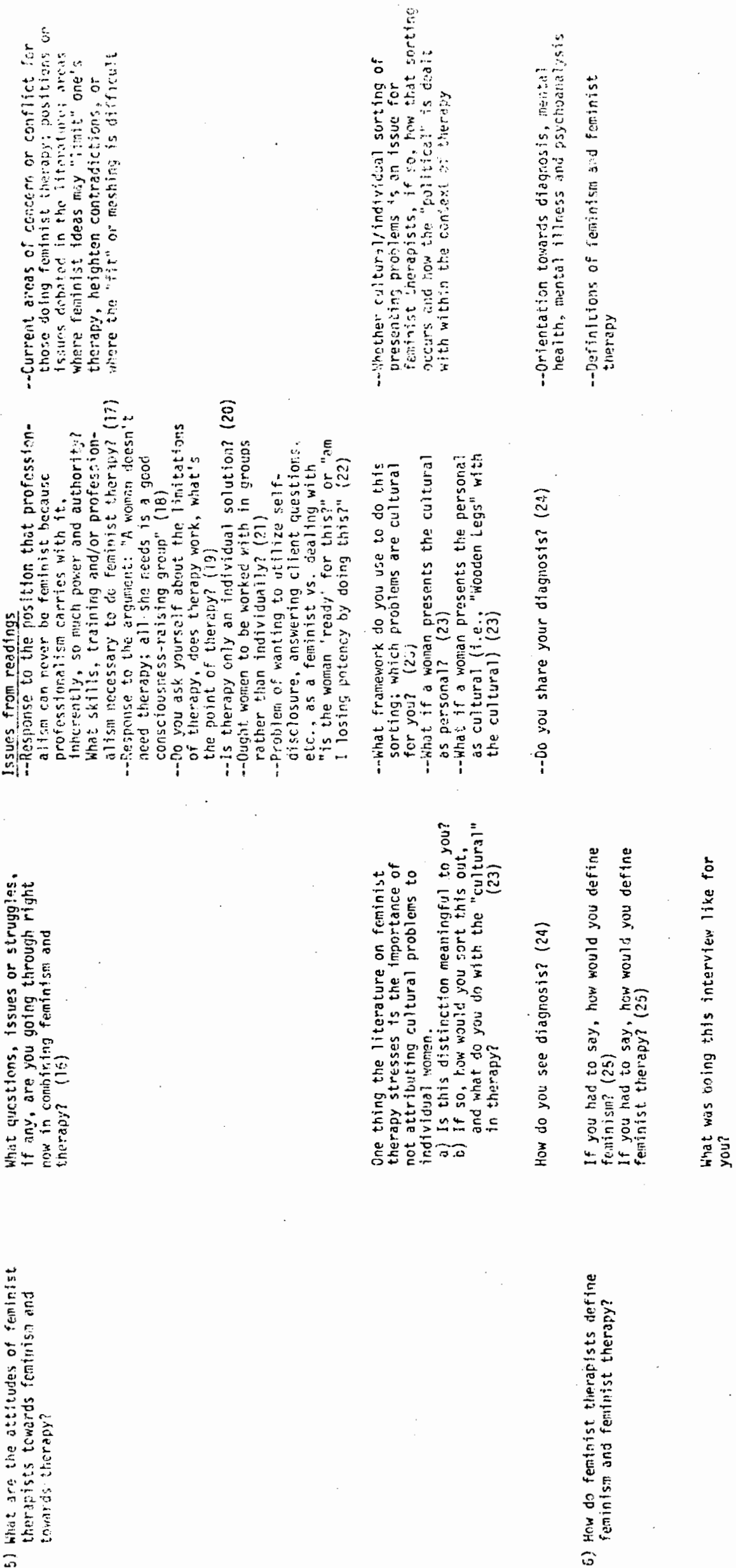


\section{APPENDIX E}

\section{BERKELEY FEMINIST THERAPY REFERRAL COLLECTIVE.}

Sandy: The Therapy Referral Projected started. . . [at the Berkeley Women's Center in] January or February of 1973. . . . There were a few therapists on file that we could refer to that somebody knew and had spoken to. There wasn't any kind of evaluation system. . . A . . . preliminary questionnaire [was devised and] sent to therapists which on the bottom said, "Do you know any other therapists we could send this to?" That was how we began to get names. . . . Then it began to catch on. Other therapists heard about it and wanted to get on at the referral center because it was a good way to get referrais. . . Then, that fal1, $I$. . . developed a iist of questions that $I$ felt were important to ask, some guidelines for interviewers ....

Laura: [Now] we have a whole book of forms that have been sent back of therapists we haven't had time to interview. One way that we started to narrow that down was to tell therapists that we were only going to send referrals to them if they accepted some low-fee clients. That eliminated some. . .

Sandy: The difficulty for us in a lot of ways was we were going through a lot of interrial struggles at the center. There's always a changing [volunteer] staff here,... So it's real hard to maincain a therapy referral projec: with people knowing the therapists that they're referring to when [the referral staff] keep coming in and out. It's a pain in the ass to keep calling up the therapist and saying, "We want someone else to interyiem you now." So we would write up.. "a basic summary of each intervien with each therapist that we could have on file, and if somebody had a dissenting opinion, that would be written too.... I think in some ways. . . that the orset of the women's movement left a lot of room for womer who had a ready become therapists and were in private or group practice to say, "We1l, far out, I'm a woman, therefore I'm a feminist therapist," and kind of exploit the women's movement.

Laura: A7so, women frequentiy in answering the questions and in filling out the questionnaire, iry to figure out what answers we want. . .

Sandy: So partiy a sorting thing [again] is financial. . . The other issue for me is an incuitive sense about a woman and it's real subjective in terms of whether or not I think she's a feminist in certain ways. [Yet] the range of women coming in here wanting therapists is so great that I can't al ways say, "No, you can't be in our files because we would never find anybody who would inatch up to you." Sonebody who I might tinink 
is not feminist somebody else might think is feminist. It's terribly complicated. There have been some cases of women where I just wouldn't trust their therapy at al?, in terms of them not having any political reality, any sense of the struggie that women go through and any willingness to share their own struggles with another woman. . . .

Laura: [If a woman wants a referral] generally, we don't refer over the phone; we ask her to come in. We were doing them Thursday nights from 7 to 9 and we extended trem. At one time it started out with a rap, and that petered out; we'd like to get it going again. We'd like to try out. having women come and talk to each other for an hour and then do individual referrais. . [which vary] from 10 minutes to half an hour. I think we all do [the referring] really differently, too. But the similarities are mostiy that we try to get some sense of where the woman's coming from, what she's looking for, what she expects, and how much money she can pay. . . . Sometimes women come in and really want to talk, right then. And sometimes women come in and say, "I want this kind of therapist. This is how much I can pay." Usually it's somewhere inbetween... Usually it comes down to [me referring to] the peopie that I have had some kind of personal contact with. . . Like, Sandy might refer to the therapists that she knows best, and I would refer to the ones I know 'cause those are the ones that I feel most confortabie with. Ideally, you all would know them all more.

Sandy: I feel comfortable making a referral to somebody I haven't met if someone else in my group has met them. What I usuaily do is teli the woman, "I haven't met this person. I've heard this and this arid this about her. If you feel uncomfortable with that and want to know nore, then I can get you in touch with the person who interviewed her. "There are some therapists in the file who have been interviewed by women who were at the Center and are no longer at the Center. We haven't done a re-interview of them. We try to make three referrals, encourage the woman to shop around for a therapist. [tell her] that she's not nuts if she doesn't like a therapist--she should trust herself.

Laura: I've had a lot of experiences too where women really are afraid to do that, and you really have to encourage them. They say, "What do I do after I go to one interview? Is it OK to then . . . ?" They don't believe it's $0 K$ [to shop around].

Sandy: It's such a woman's thing to say, "I'll hurt her feelings too much if I tel? her I don't want to [be in therapy with her], "so I make it a point of saying, "Everybody on our files knows that it's a women's Center policy [to encourage shopping] and have agreed to it. You tell her you were referred by the women's center and that you're shopping."

Laura: This gets said a lot: "I feel like I can taik rings around a therapist. I want someone who won't let me do that." or, "I want someone who won't push me too much." Those are the kinds of things that give you a sense [of who to refer to]. . . Also sometimes women have really strong feeling about, age. . . [or] credentials. . . That doesn't happen a iot but if someone says that I talk about [it]. 
Sandy: Also trying to get a sense.. . if they [really] need to be in therapy. For the most part, somebody who comes in here and says she wants to be in therapy, :. . I generally say OK. But a couple of weeks ago, for example, there vas a wiman who came and she didn't know what she wanted. She knew she wasn't foeling very much support in her job. She was feeling bad about herself; but it wasn't like she was going through some traumatic crisis in her 1 ife. . . I really pushed her to be in a support group with other women and then if she felt she wanted to work individually with somebody or be in a more intensive therapy group, then she should come back and she shouldn't feel hesitant about that. . . . One of the things that we're trying to do here is show women that there are alternatives to being in therapy, that to get support from - other wornen around certain issues and to get strength from other women is a real viable healthy alternative to being in therapy.

Laura: I refer a lot of women, if they are going on to individual therapy, to be in a consciousness-raising group as well. That's important to me to offer that as an alternative. . . We also have a feedback form we use, for after the client has been to the therapist. We haven't had a lot of success in getting those back. . . When I don't get the form back, I always kind of assume that it didn't work out.

Sandy: I cion't assume that. The forms that we send out are kind of laborious to fill out. . [but sti11,] we don't have any way of checking up other than a phone call, and that was an issue we dealt with for a while because we dian't know if it was a breach of confidentiality, or intruding on somebody's ability to choose [to call them]. . . [but] not getting anything back, we don't know how good the people are that we refer to... From a client standpoint and how many people are reaity making use of what we do.

On the following page is a copy of the hand-out they give women who come in for therapy referral. 
On Choosing a Therapist:

The Berkeley Feminist Therapy Referral Collective

Choosing a therapist is a personal process. As women, we have been trained to make the assumption that "the therapist knows best" without paying attention to our own needs ard feelings. This is one way that we give away oul power.

It has often been our experience that women seeking therapy enter the first meeting feeling that they are "sick" or "crazy" and therefore have no grounds on which to be discriminating or critical in sizing up the situation.

We have put together some guidelines intended to heip you stay in touch with your own strength when determining whether a therapist is someone you want to work with. The main thing to keep in mind is to trusi your feelings and reactions, and that "shopping around" for a therapist is $0 . K$.

Things to Be Aware of:

1. How an I feeling with the atmosphere? i.e., our irtroductions, the room. Am I comfortable, uncomfortable, anxious, excited?

2. What are my first impressions of the therapist? An I feeling comfortable enough to ask questions oi concern to me?

3. Do I have the space to direct the conversation if I want to?

4. How do I fee? when the therapist chooses not to answer a question? (Be aware of the questions she's not answering.)

5. Has the therapist heard what my needs are?

6. What would I feel uncomfortable talking to this womar about? What things would I be afraid to tell? How would I be afraid to behave?

7. How much is the therapist telling me about me?

Questions you might want to ask:

1. What's your philosophical background, therapy orientation, training?

2. What can I--what can't I--expect from theropy, from you?

3. Money: are fees negotiabie? etc.

4. Time contracts: Example: let's meet for 3 months and then re-evaluate how we're feeling. Do you feel open to evaluation?

5. Availability: Would you be available to me at other than regular appointment times? As in a crisis?

me?

5. How do you feel about sharing your personal experiences with

7. How do you feel about homosexuality, heterosexuality, single mothers, etc.

8. Types of therapy available: Do you offer individual, groups, family, couple, etc.? 